\title{
PICTURES OF
}
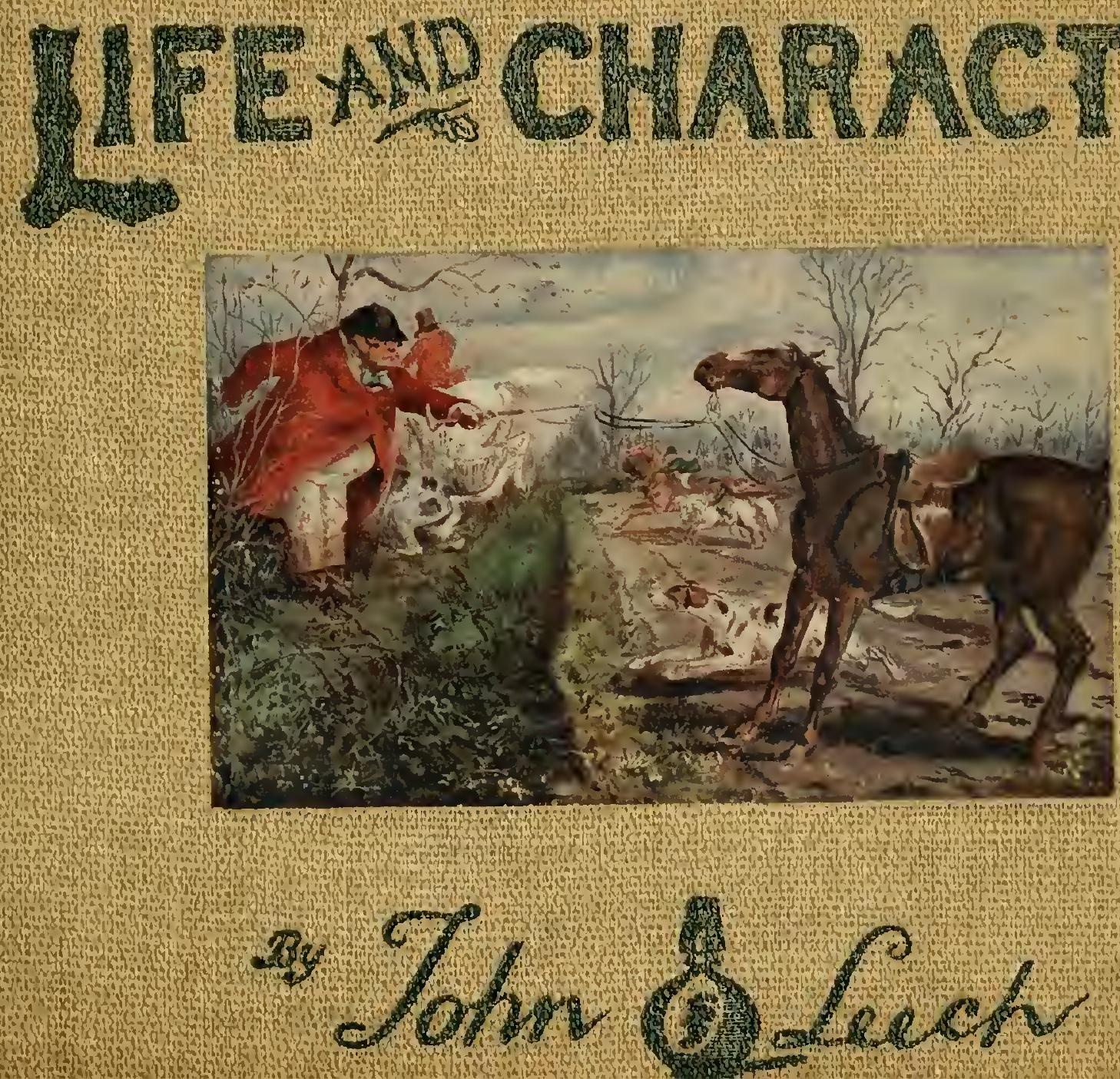


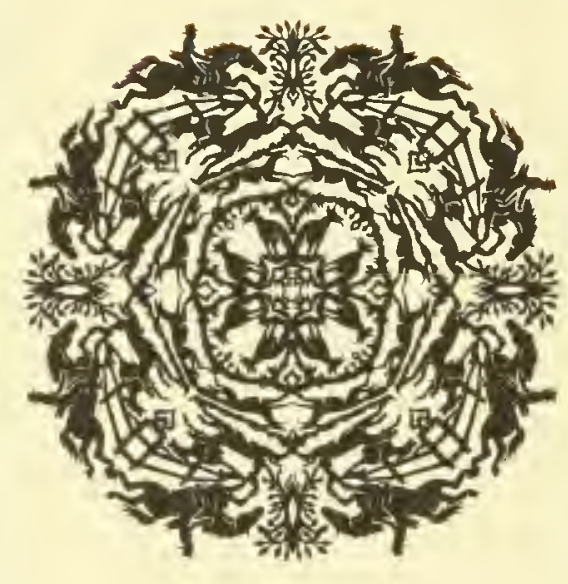

JOHN A.SEAVERNS 
III

3090 9090014564369

Webater Family Librany of Veternary Aledicine Curamings Schocl of Veterinary Modicne at Tufis University 200 Westboro Froad Math Grafton, MA $015 \%$ 


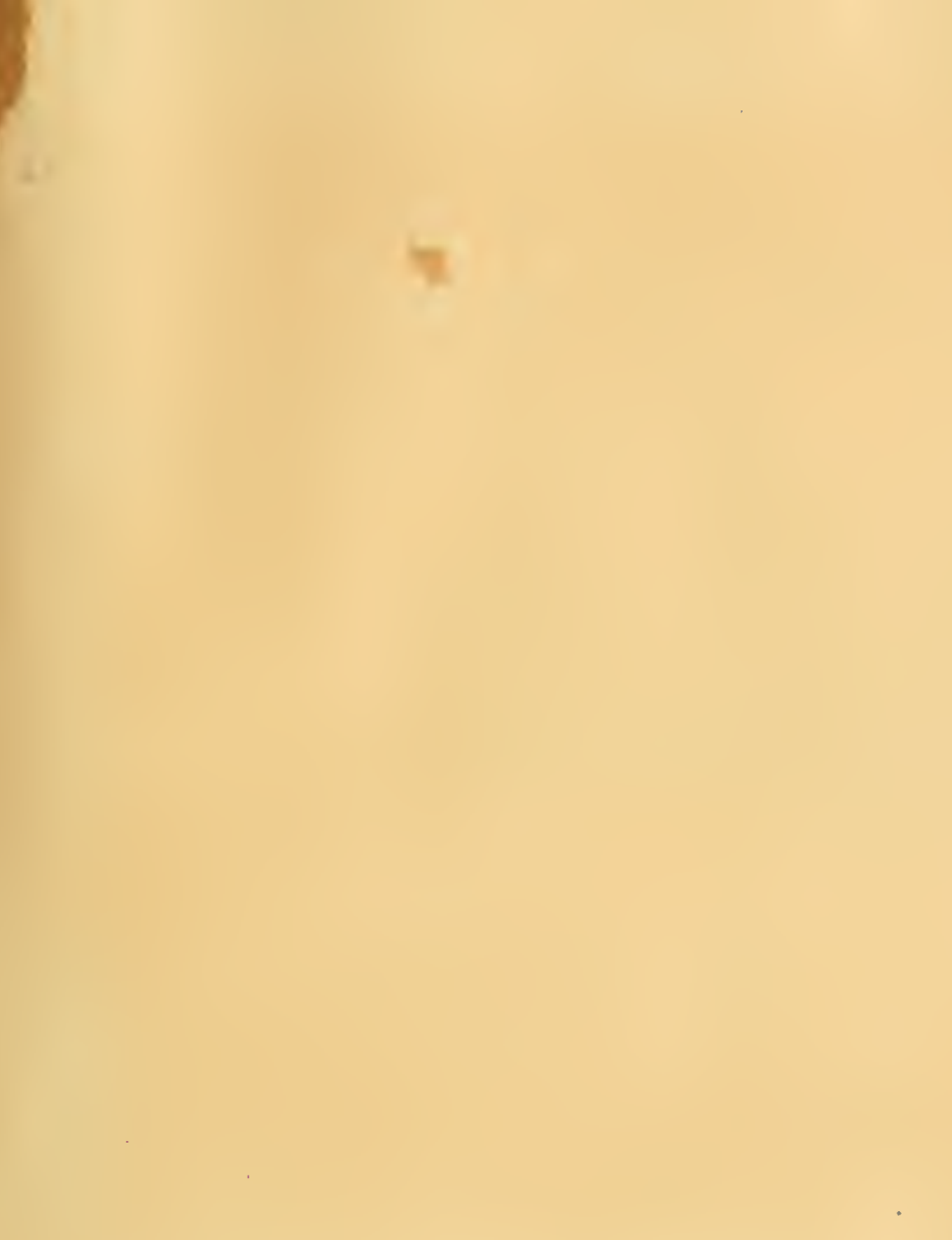

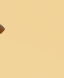

.

n - 


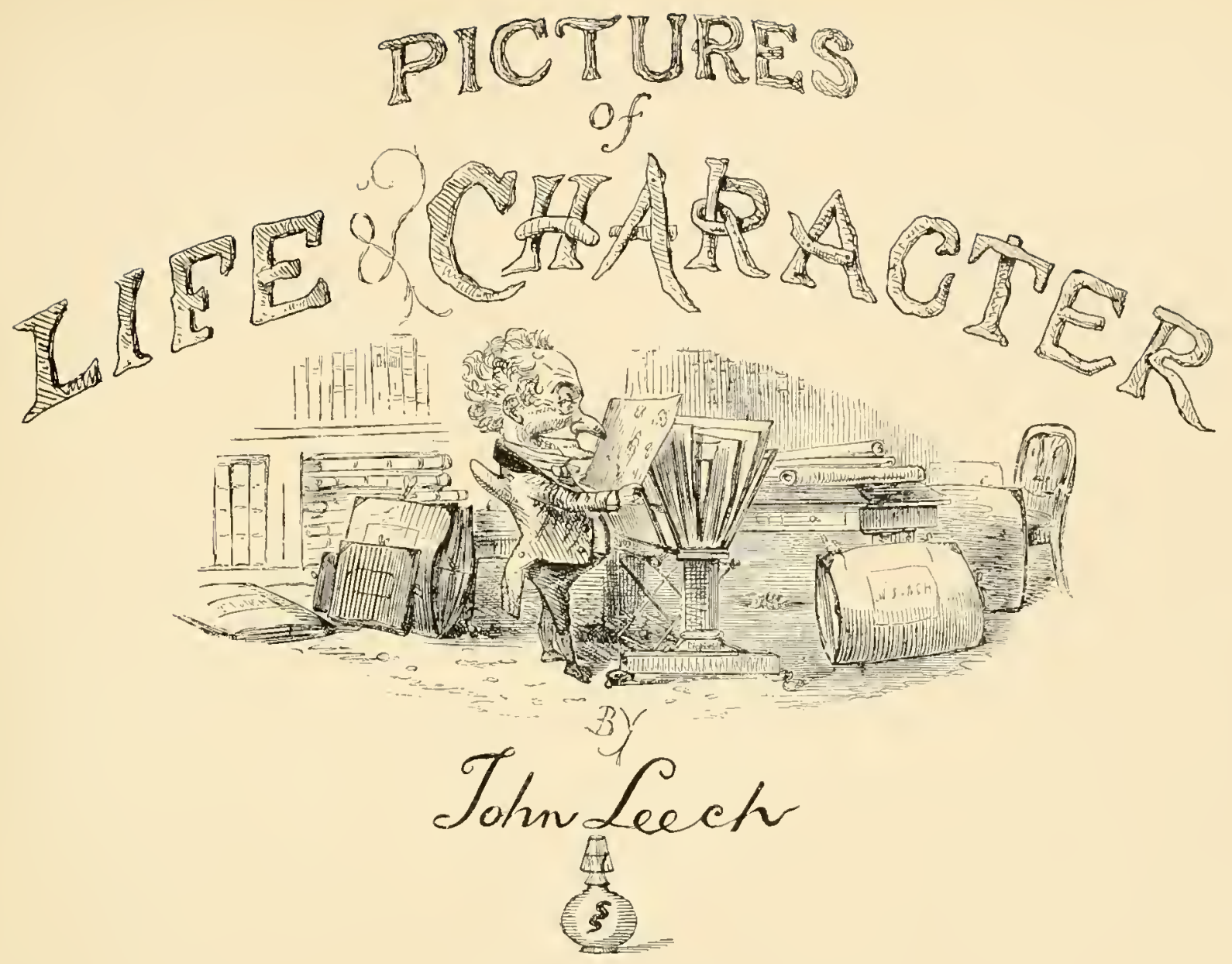

New York

G.P.Putnam's Sons

London 



\section{PREFACE.}

"Think," said Thackeray, "what a number of Punch would be without a drawing by Leech in it!" In these words, the great writer has voiced the regard in which all Englishspeaking people have held the man who, for nearly a quarter of a century, was the lcading spirit of Punch. The versatility of his genius was remarkable, as revealed in the unerring accuracy with which he depicted the humour and tragedy of life in the streets of a great city, in his unrivalled scenes of incidents in the pastimes of a sport-loving people, in his sparkling caricatures of English home-life, and in the power of his political cartoons.

John Leech won the hearts of his countrymen not alone by the high artistic merit of his work and the exquisite wit and humour of his drawings, but by the fairness and sympathetic spirit which he manifested in all his productions. His drawings, like the great weekly which he so iargely helped to make famous, were suitable alike for the nursery or the club. Lord Russell, after the appearance of the famous "No Popery" cartoon, in which he was brilliantly caricatured, remarked, "It was a fair hit." The same might be said of all the artist's caricature work. Add to this element of fairness an eve kcen to see the clominant human interest in every-day scenes, and an intellect ever ready to grasp the very kernel of wit in the speech and manners of all about him, and we have the chicf contributing factors to his popularity.

The one flaw in the artistic make-up of Leech, his impatience of technical detail, had it been overcome, woukd have lost to the world the thousands of sketches which still deiight those acquainted with them hardly less than when first publishcd. Amid all his intermittent attempts to do serious work in oil, his constant cry was, " When you can see what a mar intends to convey in his picture, you have got all he wants, and all you ought to wish for; all elaboration of an idea after the idea is comprehensible is so much waste of 
time." Faithfully as the artist adhered to this principle, it is none the less true that eren without elaboration his drawing is vividly realistic in its expression. Every posture is correct, his charaeters are living erery-day people, and in his sporting sketehes, which are largely represented in this collection, this quality is pre-eminent. No man in England knew the land of sports hetter than he. Henry James remarks of this side of his work: "He gave in a few strokes the look of the hunting-field in winter-the dark, damp slopes, the black, dense hedges, the low, thick sky. Irech depicted, with infinite vividness, the accidents of the ehase and the fishing-season; and his treatmont of the horse, in espeeial, eontributed greatly to his popularity. He understood the animal, - and drew him as if he knew how to ride as well as to draw." 
- There is far more fun, more good drawing, more good sense, more beauty, in John Leech's Punch pictures than in all the Art Union illustrations, engravings, statuettes, etc., etc., put together."-Dr. John Brown in his "Notes on Art."

"The truth, the strength, the free vigour, the kind humour, the John Bull pluck and spirit of that hand are approached by no competitor. With what dexterity he draws a horse, a woman, a child. . . . You see youth, strength, enjoyment, manliness in these drawings."-W. M. Thackeray.

"His work contains the finest definition and natural history of the classes of our society, the kindest and subtlest analysis of its foibles, the tenderest flattery of its pretty and well-bred ways, with which the modesty of subservient genius ever immortalised or amused careless masters."-John Ruskin. 



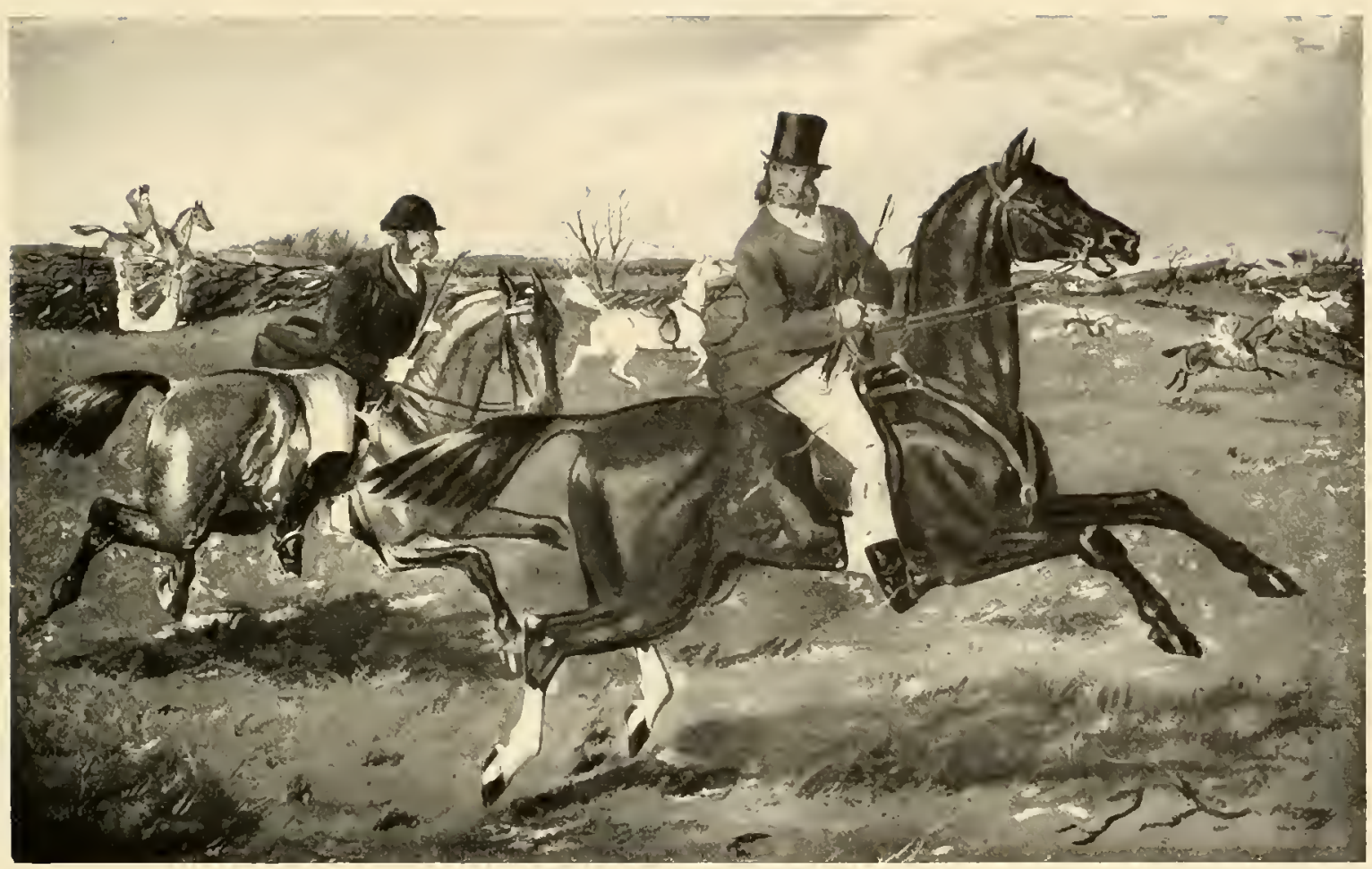

NO CONSEQUENCE.

"I say, Jack, who's that come to grief in the ditch?"

"Only the Parson!"

"Oh, leave him there. He won't be wanted until next Sunday!" 


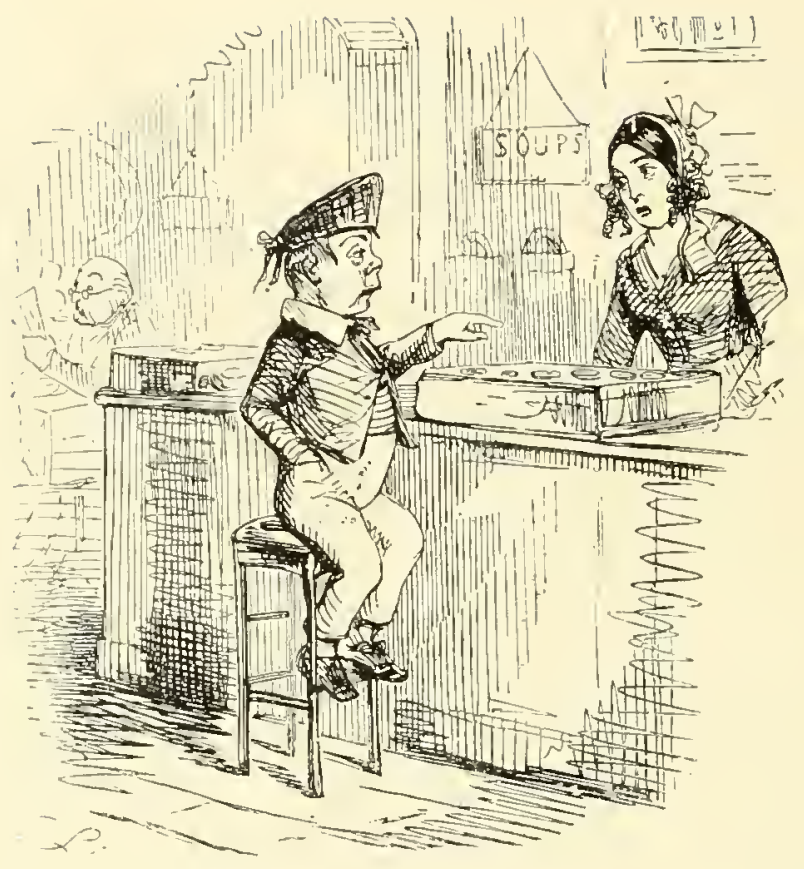

SOMETHING LIKE A HOLIDAY.

Pastrycook. "What have you had, Sir?"

Boy. "I've had two jellies, seven of them, and eleven of them, and six of those, and four bath buns, a sausage roll, ten almond cakes - and a bottle of ginger beer." 


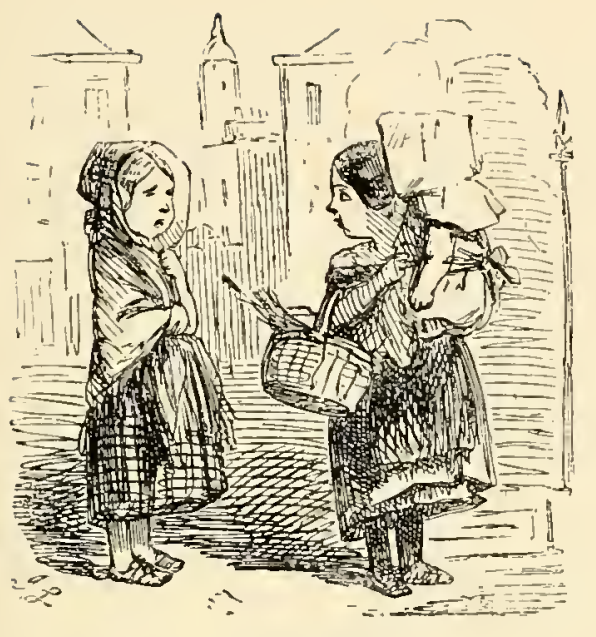

PROPRIETY.

Persons represented. Sarah-Jane. Matilda.

$$
\text { Scene-Camblin Toren. }
$$

Sarah-Jane. "Oh! you 'orrid dreadful story! I didn't."

Matilda. "You did now, for I see him. I see him kiss yer. And here have I bin engaged to Tommy Price for years and never so much as walked arm-in-arm with him!"

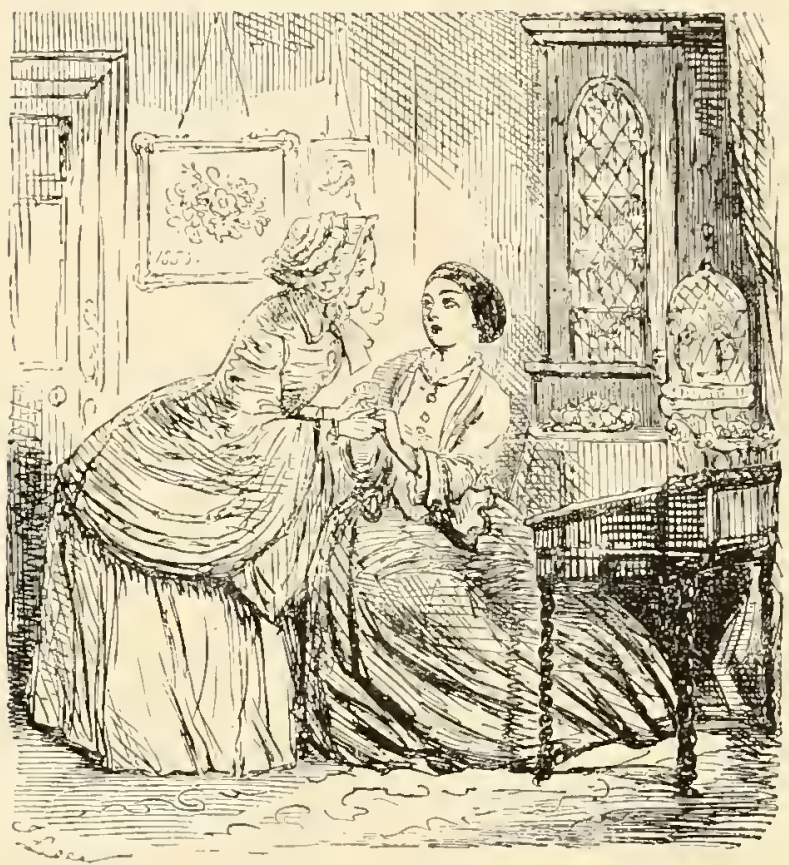

AN AFFAIR OF IMPORTANCE.

Harrict. "Oh! I'm so glad you are come, Blanche! I've been so perplexed I could scarcely sleep all night."

Blanche. "Well! What is it, dear?"

Harrict. "Why, I don't know whether to have my new merino frock violet or dark blue!" 


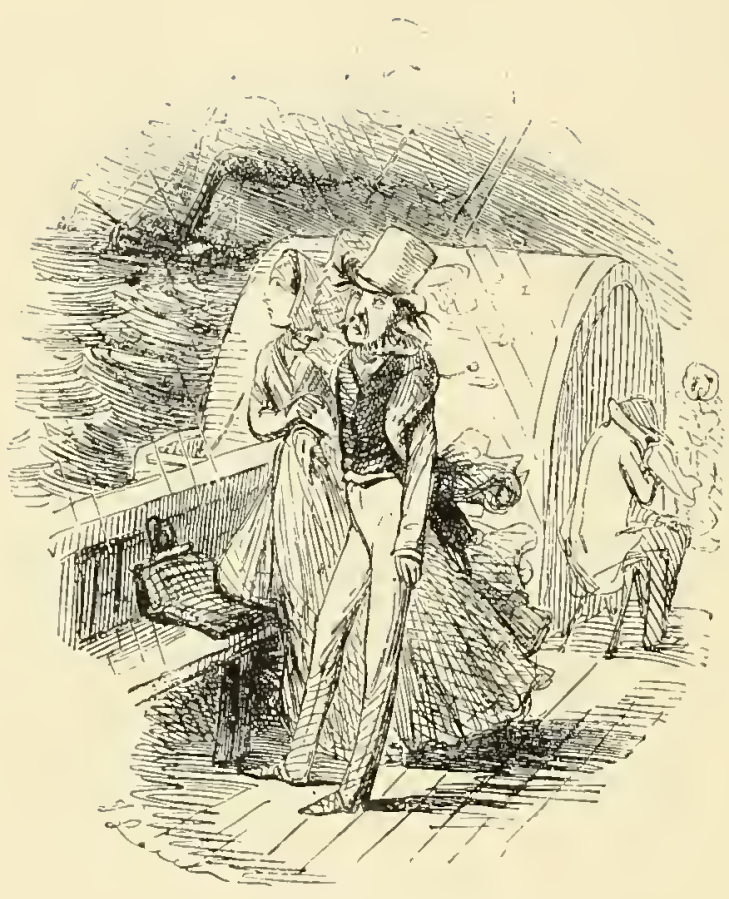

LOVE ON THE OCEAN.

" Oh! is there not something, dear Augustus, truly sublime in this warring of the elements?" But Augustus's heart was too full to speak."-MS. Novel by $\operatorname{Lad} y * * *$. 


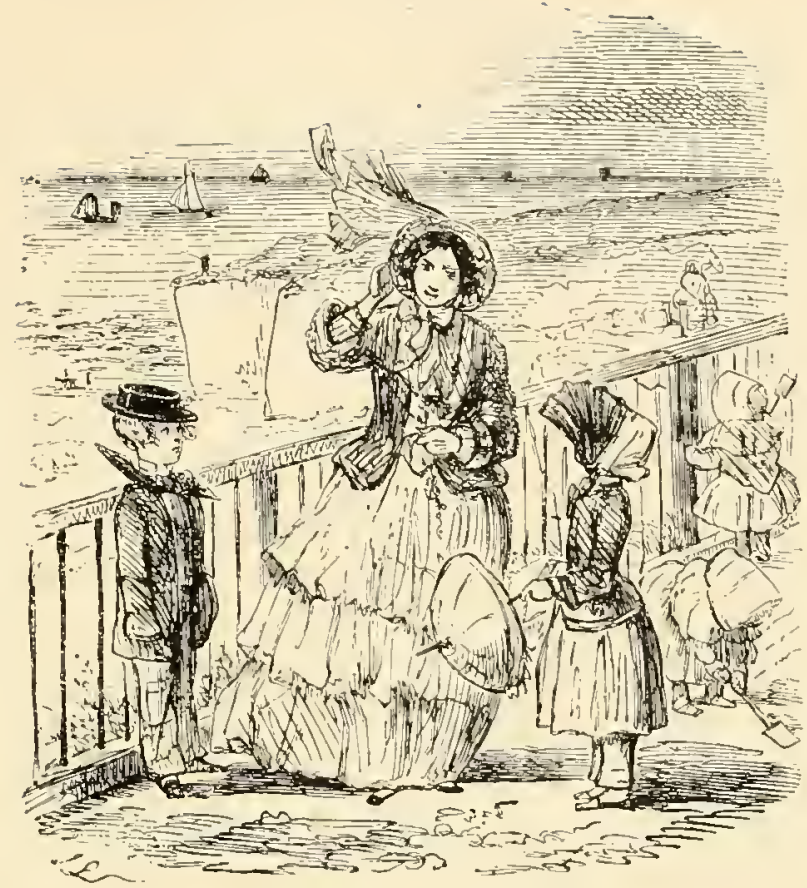

A PHILOSOPHER.

Harriet. "St, st, st, dear me, now, I've broken my comb, and all my back hair's come down. What with brushing, and dressing, and curling, and one thing and the other, what a plague one's hair is to be sure!"

Ioung Fellow. "Well, Harriet, we are all bothered with something. Look at us men; we have to shave every morning, summer and winter!" 


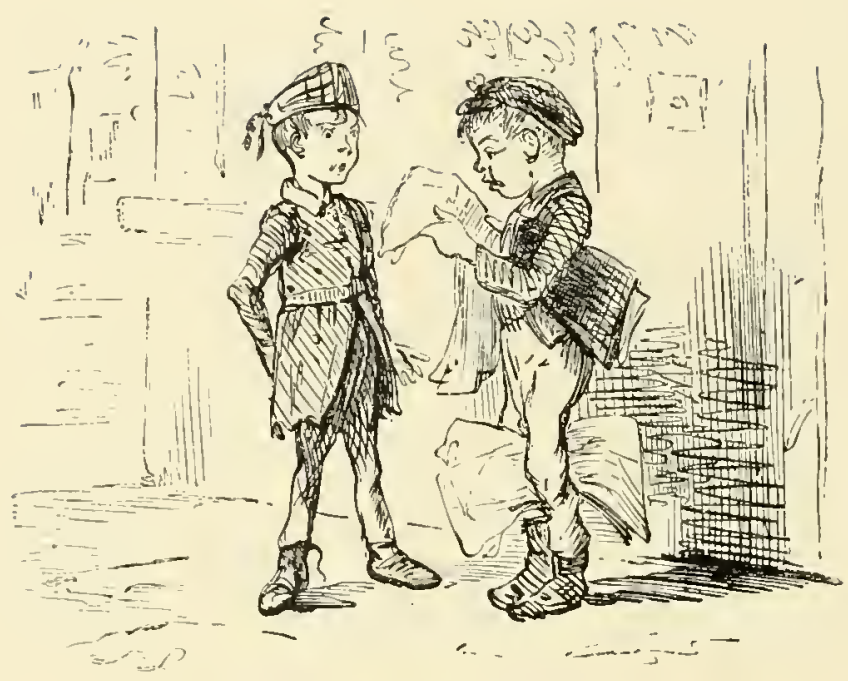

VERY FINE FRUIT.

Nerespapcr-boy (reads). "A gentleman in the $n-e-i-g-h-$ neighbourhood of _-, has at the present time several e-normous gooseberries in his garden, which measure ten inches in $\mathrm{c}-\mathrm{i}-\mathrm{r}$-cir $\mathrm{c}-\mathrm{u}$-m-cum $\mathrm{f}-\mathrm{e}-\mathrm{r}-\mathrm{fer} \quad \mathrm{e}-\mathrm{n}$-c-e-ence circumference, and are of the a-s-as aston astonishing weight of three hounces heach."

His Fricnd. "Oh, what whoppers! wouldn't I like a pint." 


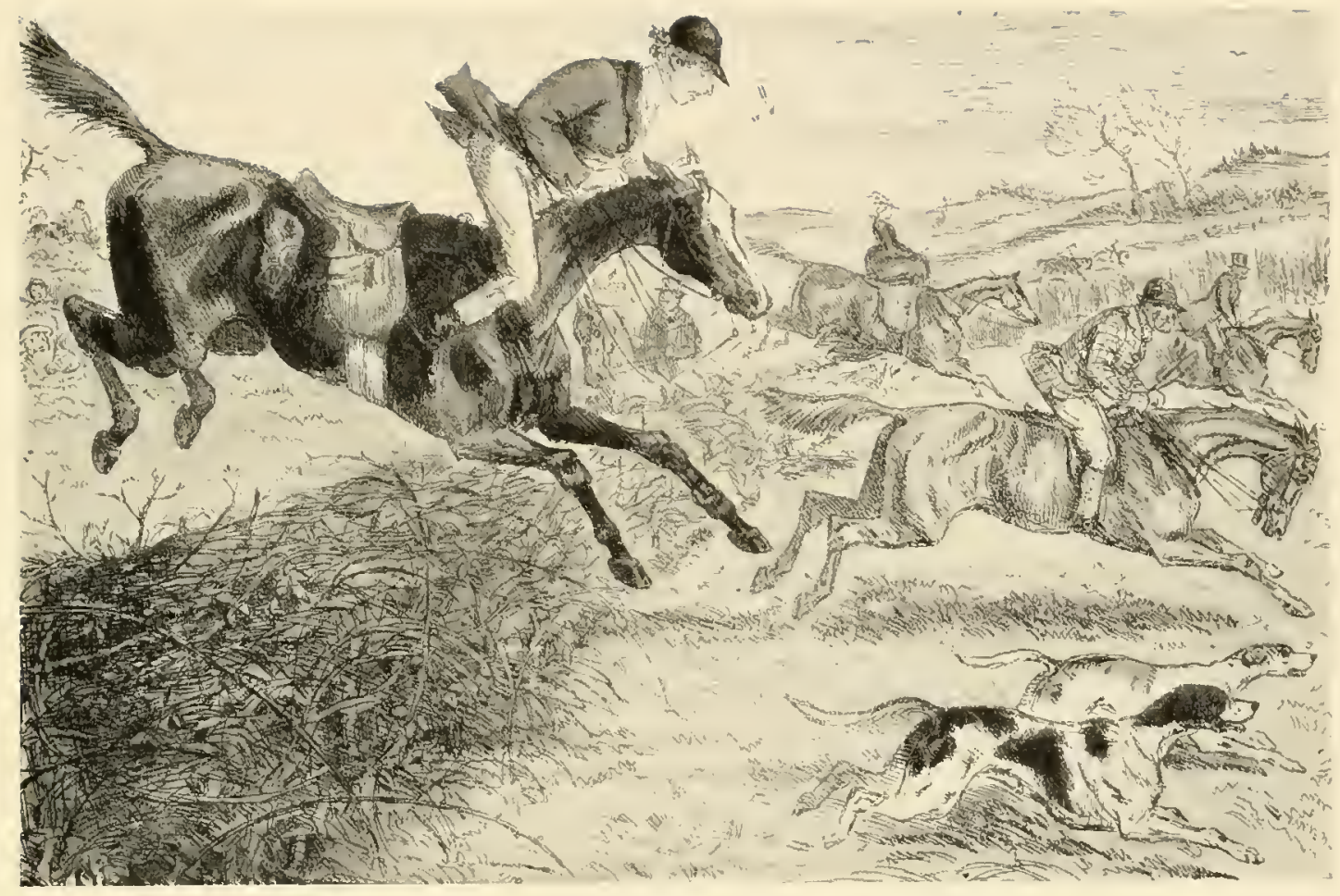

The Richest Commoner's First Jump.-From "-1sk Mammu". 


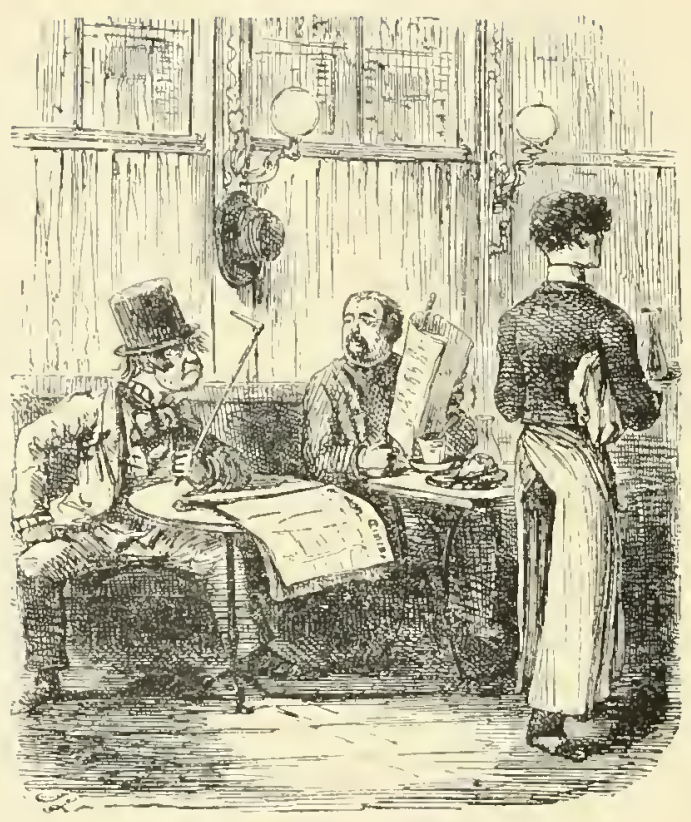

A LONDON GENT ABROAD.

Scene-A café in Paris.

London Gcnt. "Garçong! tas de corfee!"

Garçon. "Bien, M'sieu'-vould you like to see zee Times?"

London Gent. "Hang the feller! now, I wonder how the doose he found out I was an Englishman!" 


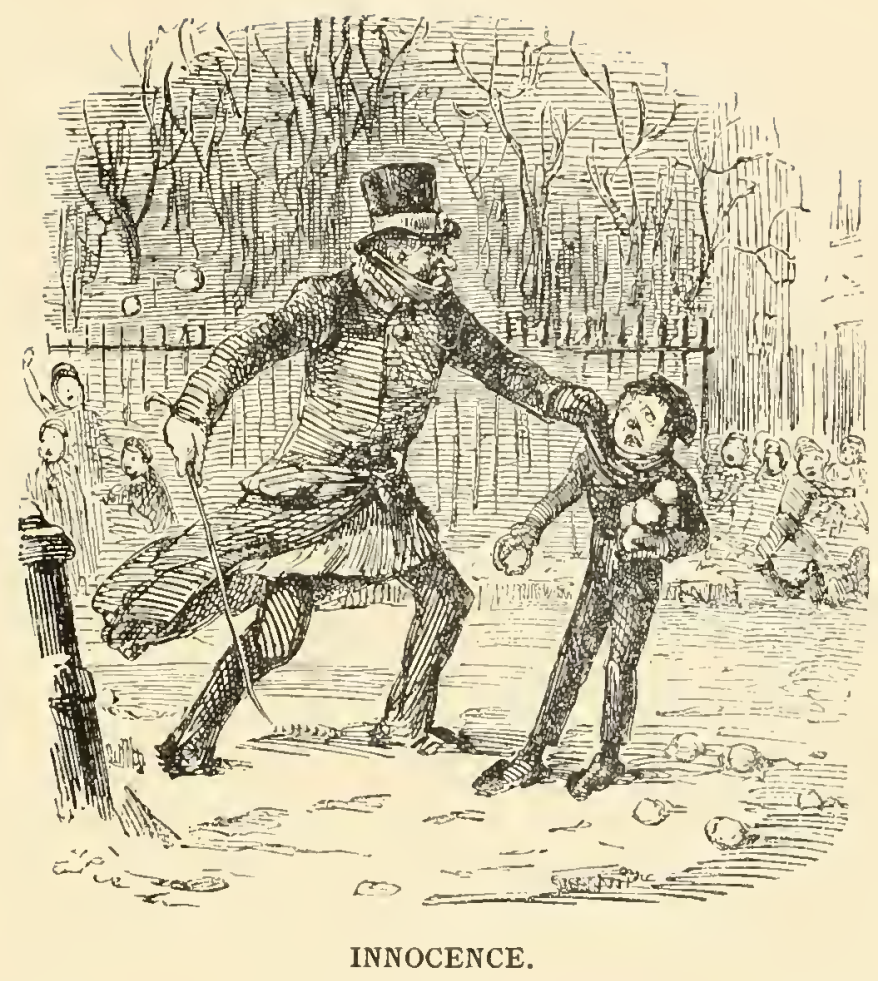

"Oh, Sir. No, Sir. Please, Sir, it ain't me, Sir! It's the other boys, Sir!" 


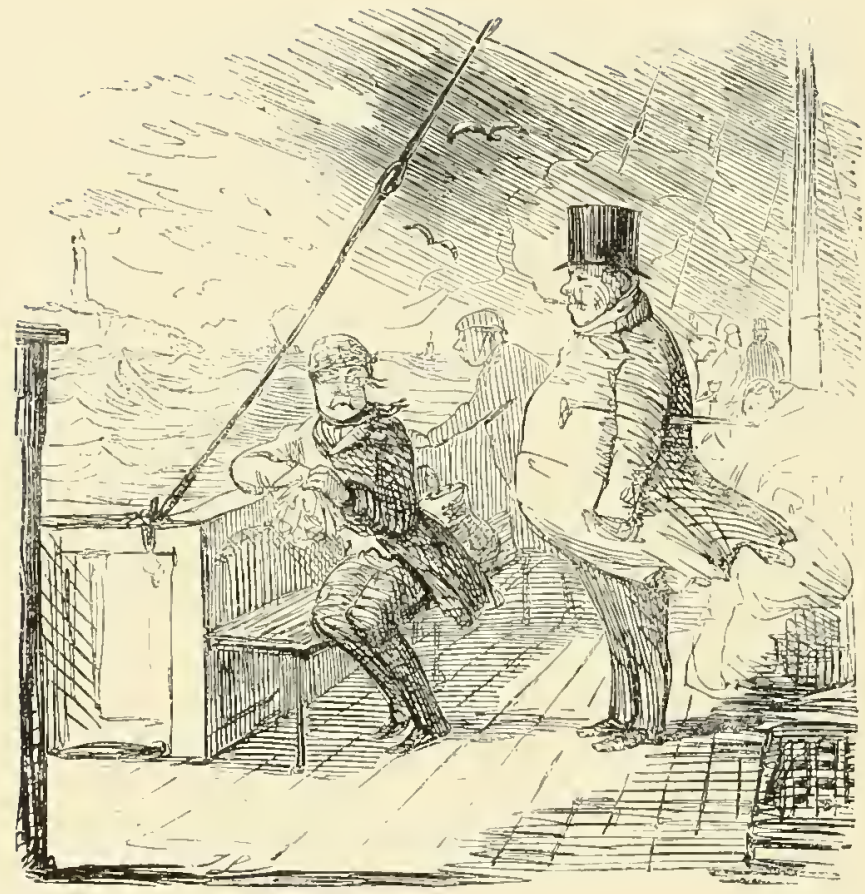

Smith. "Well, Brown! This is better than being stewed up in a railway! Eh?"

Brown (faintly). "Oh-im-measurably su-perior." 


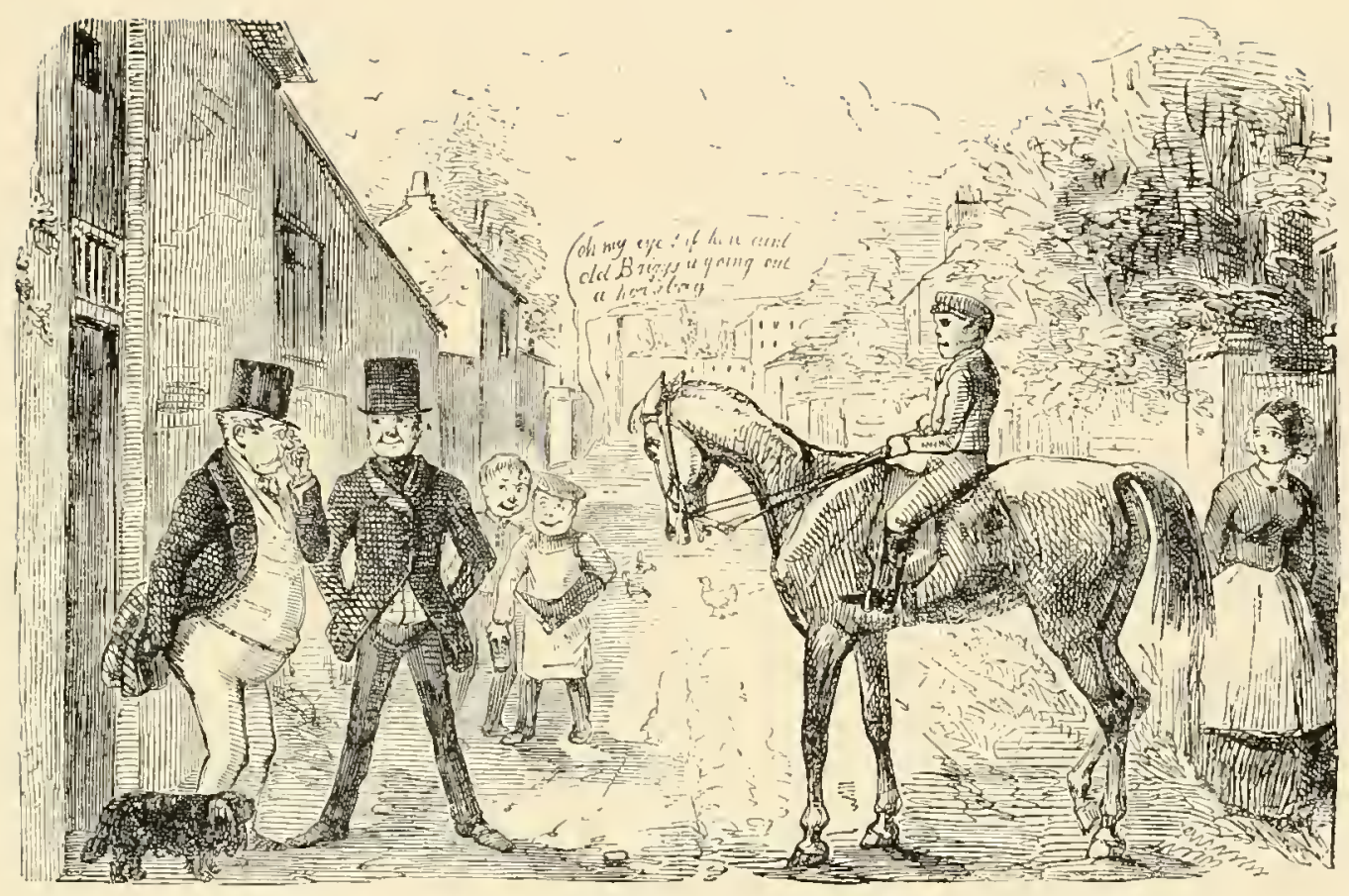

PLEASURES OF HORSEKEEPING

Dealer. "I should say it was just the hoss you want, Sir; only you must decide at once, because there's several parties very sweet upon him. He's a gentleman's hoss, Sir, and carries his own head, Sir!"

Mr. Briggs. "Bless my heart!" (Buys him.) 


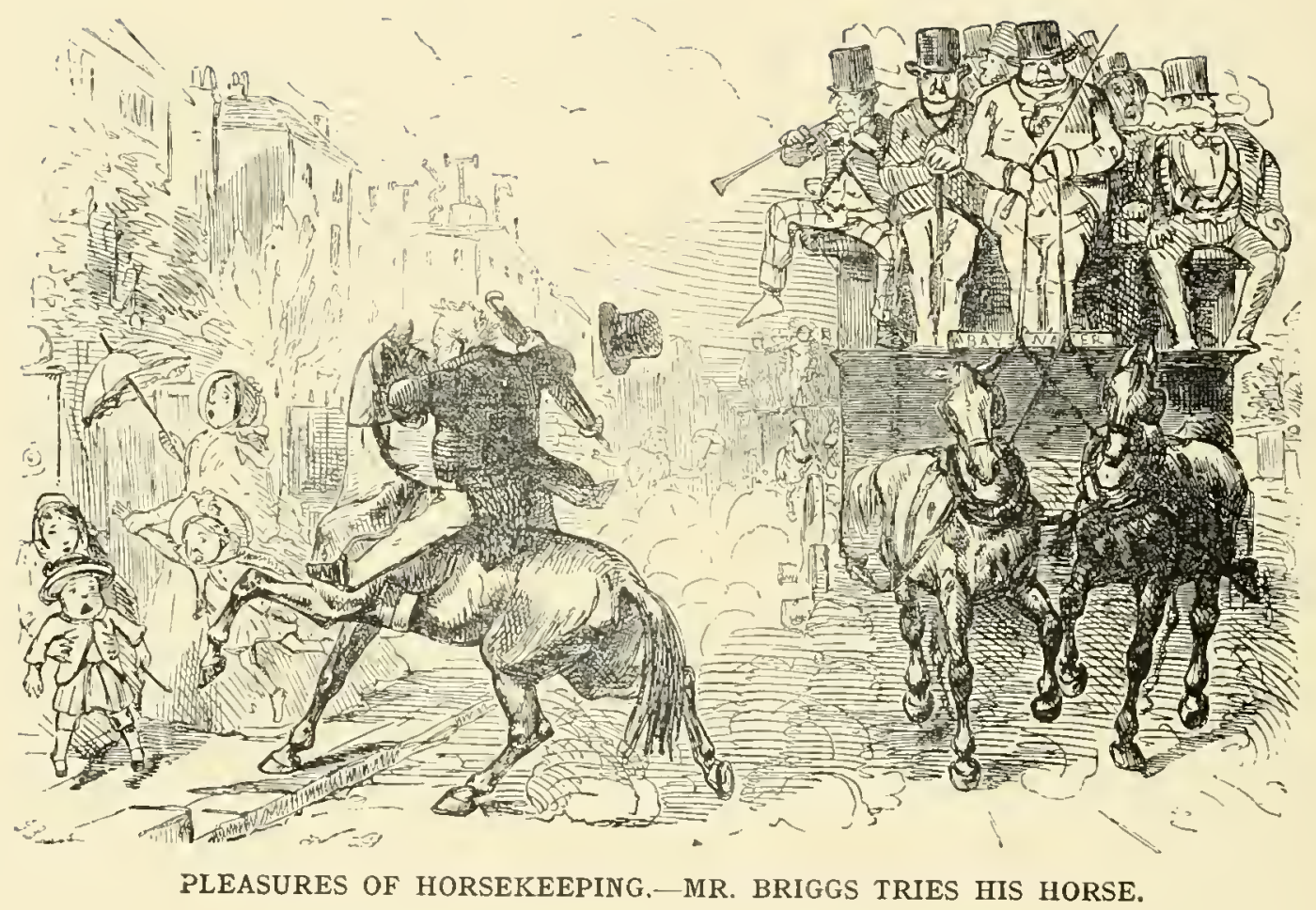

Striking effect on meeting one of those nasty omnibusses. 


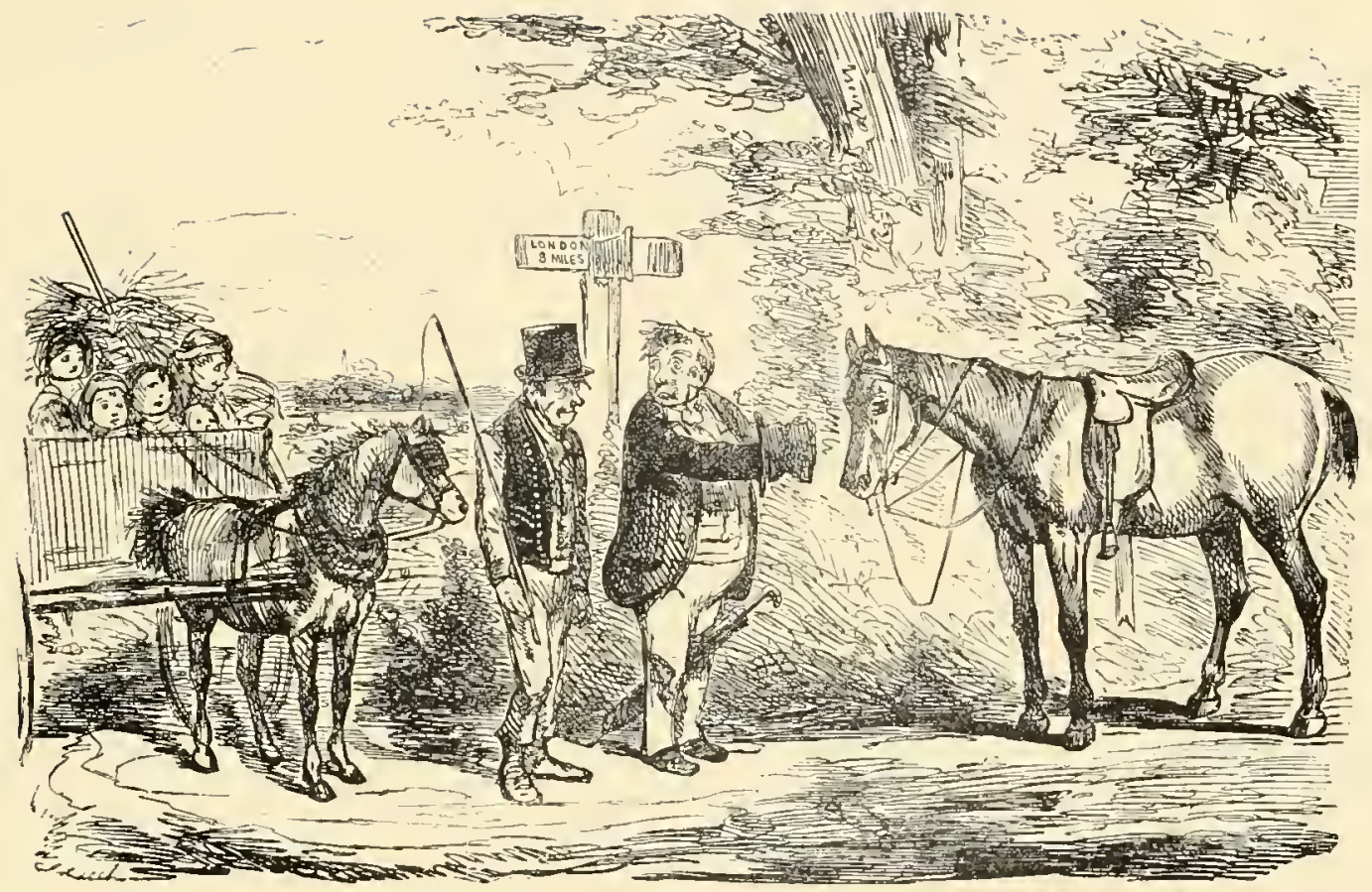

PLEASURES OF HORSEKEEPING.

Mr. Briggs (at an alarming sacrifice) gets rid of horse No. I., and goes out for a ride in the country upon No. II.

Carman. "Fell down, has he, Sir? Ah, he looks as if he could be werry clever at that.-Werry orkerd thing, Sir, for a 'oss to fall down, Sir. 'Osses costes a good bit o' money-leastways, gentlemen's 'osses does.-Now, jist look at my little 'oss, Sir, and he's a poor man's 'oss, he is. He don't go fallin' about." (Exit.) 


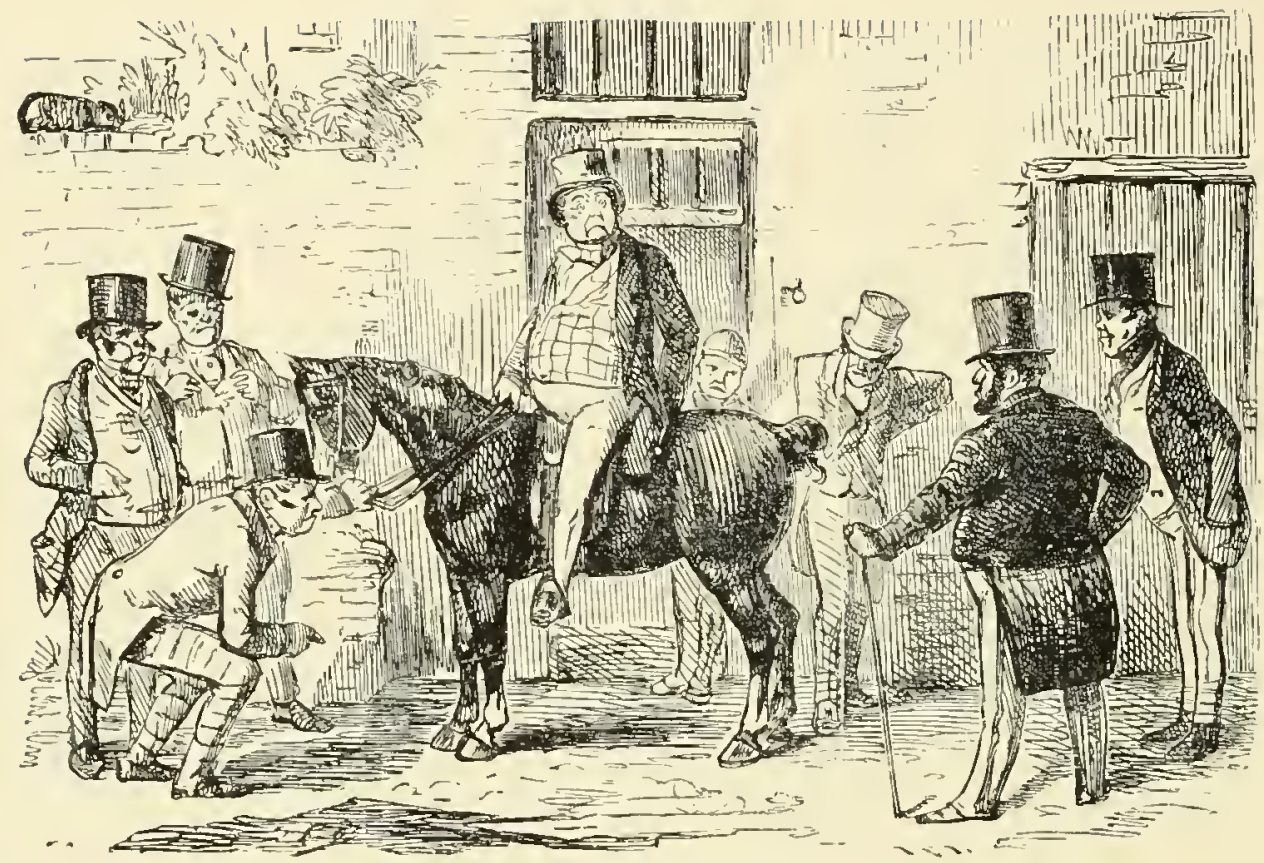

PLEASURES OF HORSEKEEPING.

Mr. Briggs, determined to have no more inferior horses, gives a good round sum for " a clever cob-up to great weightand that a child might ride." He has some friends (who really know what a horse is) to dine with him, whose opinions he wishes to have.

First Friend. "Ah-very nice-very nice-but not my sort-been knocked about a good deal, I should say-driven in a butcher's cart, perhaps, and sold because he wasn't fast enough."

Sccond Ditto. "He hasn't been down, Briggs, has he? Is that a scratch, or is it only the light?"

Third Ditto. "Does he shy at all ? His eyes don't look quite the thing."

Fourth Ditto. "I tell you what, Briggs, you must have him looked after a little better, or he'll very soon have a cracked heel."

Fifil Ditto. "That hock seems rather queer," \&c., \&c., \&c. 


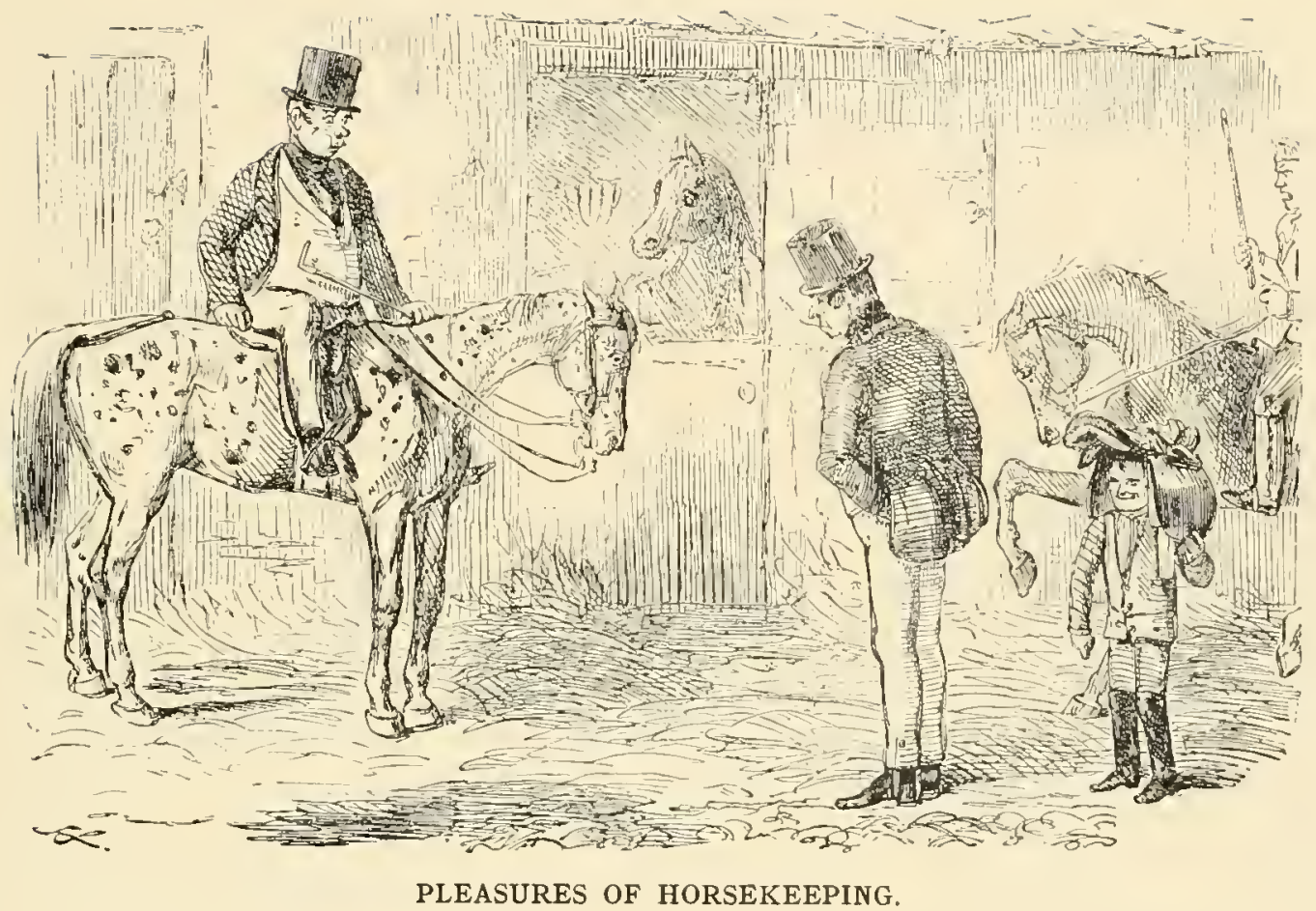

Mr. Briggs's present horse doesn't quite suit him, for, somehow, whenever he jumps, Mr. B. is sure to fall off. He takes him to an eminent dealer, and remarks confidently that he is for sale, upon which the dealer says: "How much a pound if he buys the whole of him?" 


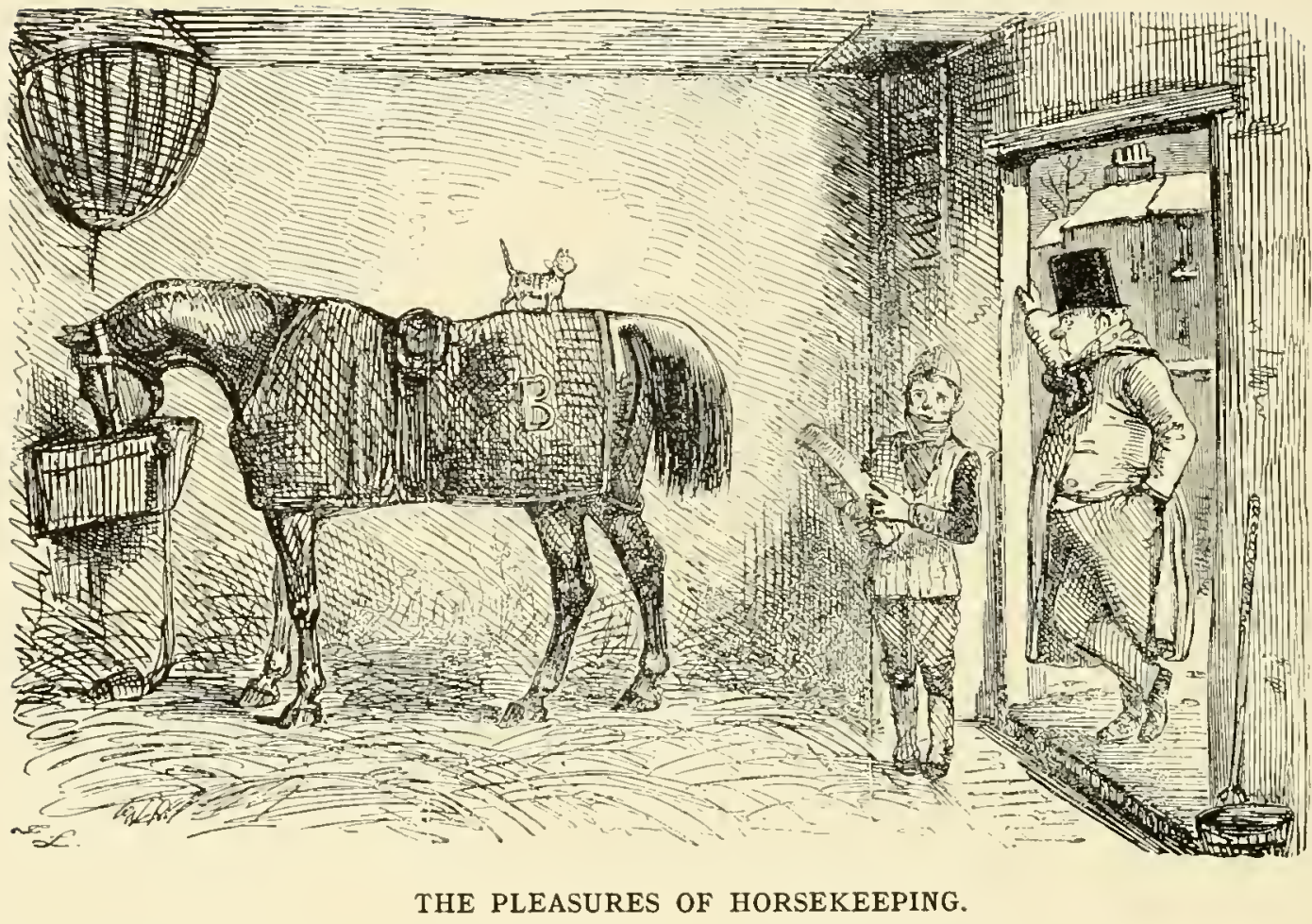

By the time Mr. Briggs's horse (which suits him exactly) has recovered from his cold, a long frost sets in.

Groom. "That's just what I say, Sir; it is aggeravatin' to see a nice 'oss like that, Sir, a doin' nothin' but eatin' his 'ed off." 


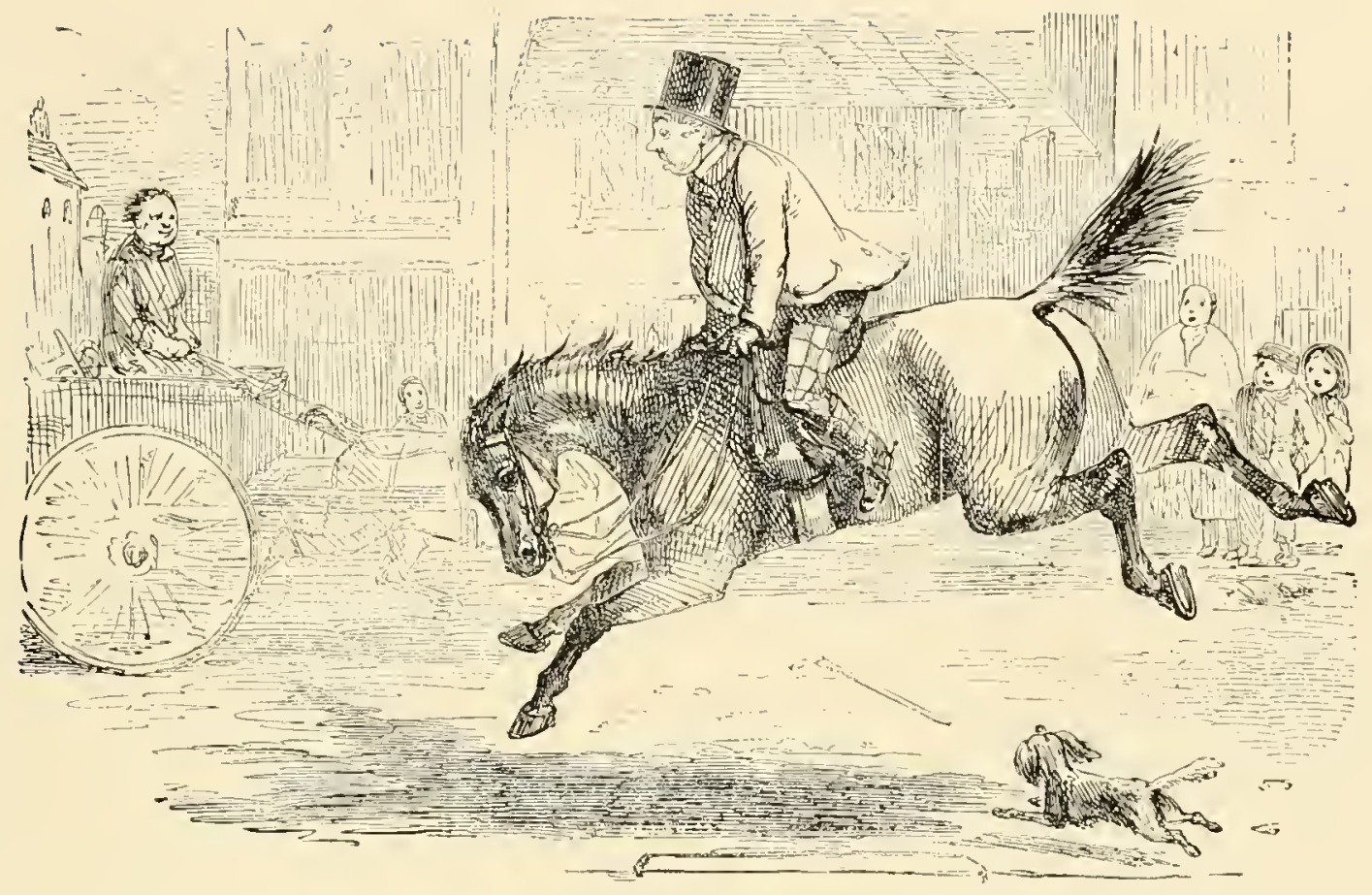

PLEASURES OF HORSEKEEPING.

The frost goes, and Mr. Briggs's horse is disagreeably fresh after his long rest. $\mathrm{He}$ sets up his back and squeaks and plunges at everything he meets. 


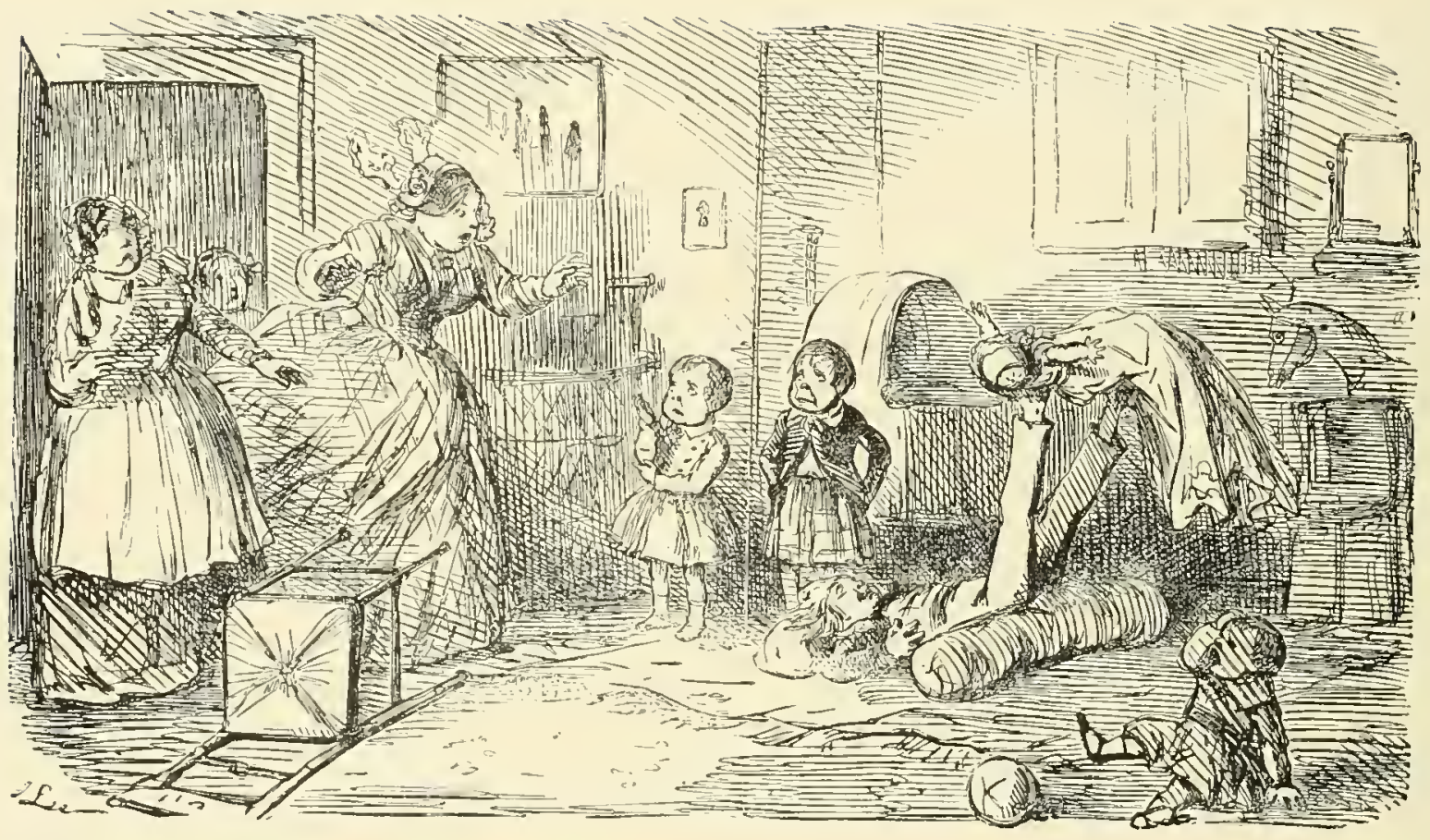

Master Jackey, having seen a "Professor" of posturing, has a private performance of his own in the nursery. 


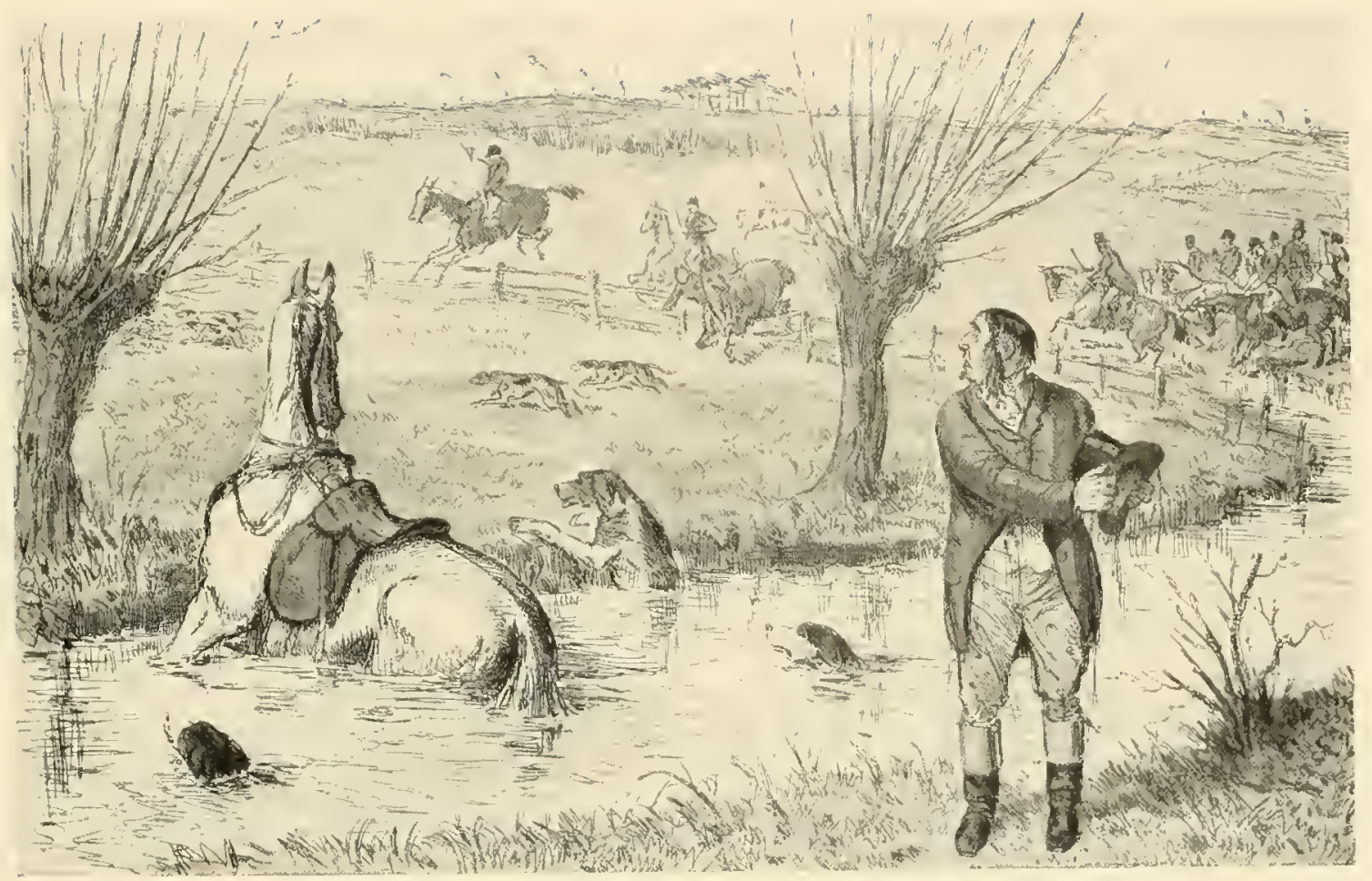

Imperial John's attempt to show the way.-From "Ask Mumma." 


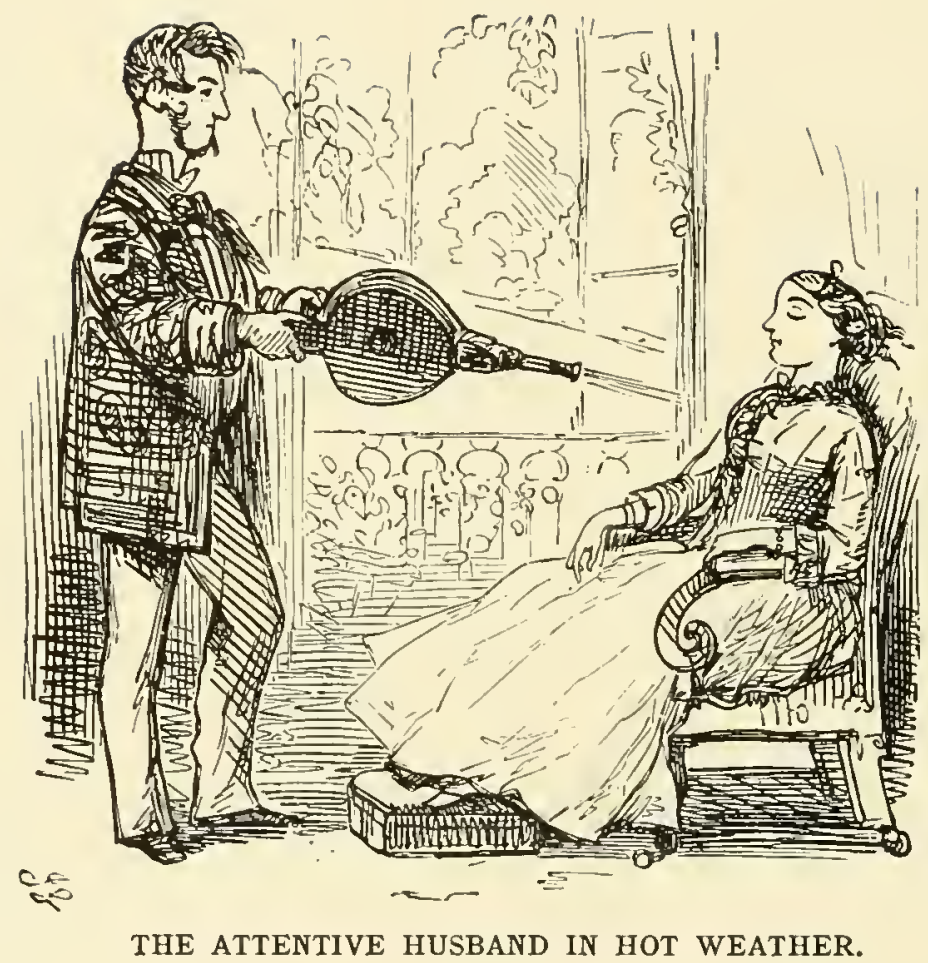




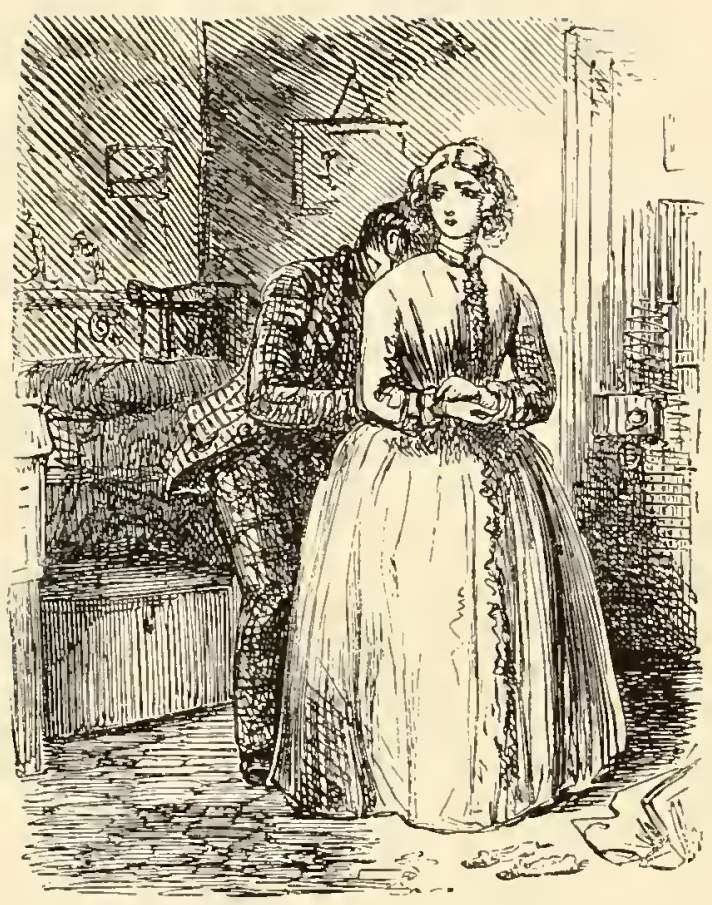

HOOKING AND EYEING.

Angelina (the IVife of his Bussum). "Well, Edwin, if you can't make the 'things,' as you call them, meet, you need not swear so. It's really quite dreadful." 


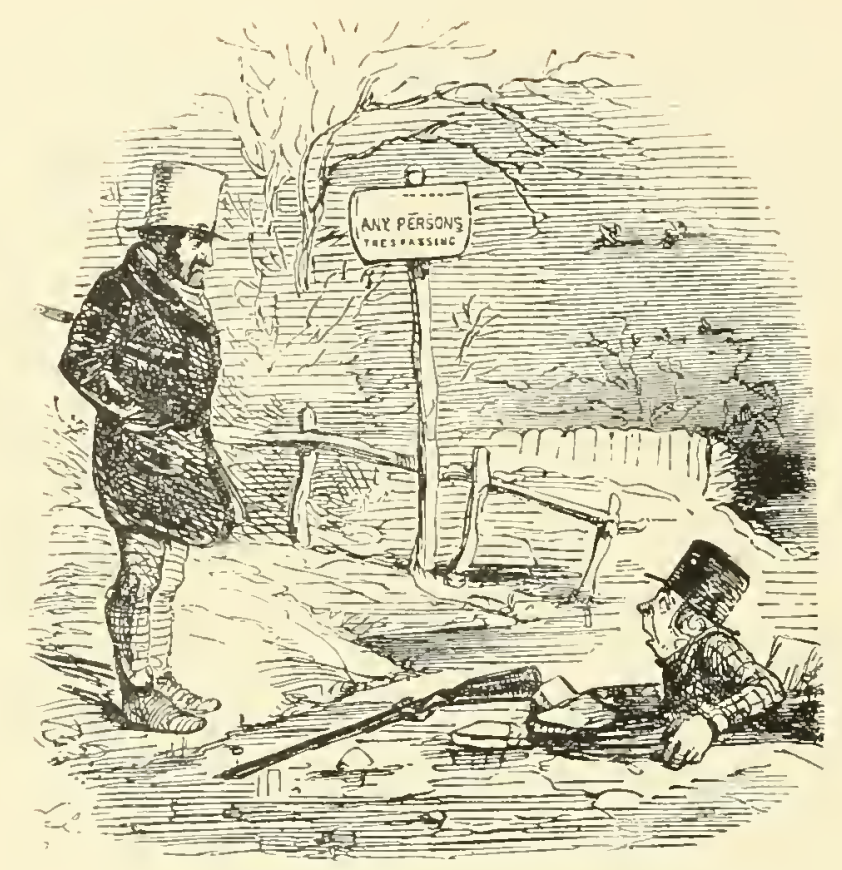

IN FOR IT.

"Hallo, Sir! are you aware you're trespassing there? " 


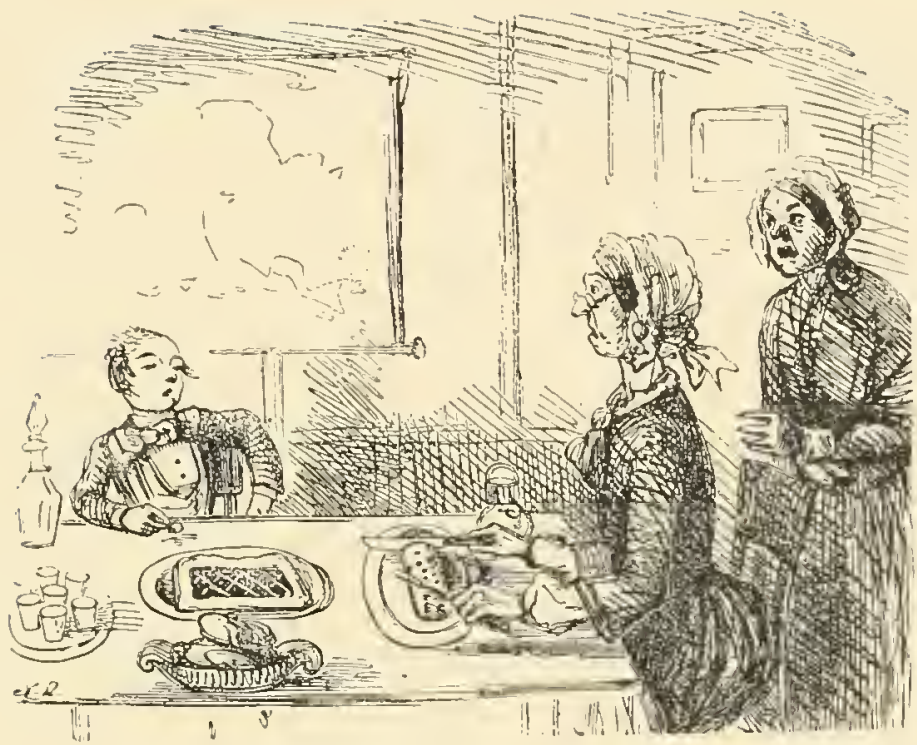

BLESS THE BOY!

Old Lady. "Now, Arthur, which will you have? Some of this nice pudding, or some jam tart?"

Juvenile. "No pastry, thank-ye, Aunt. It spoils one's wine so. I don't mind a devilled biscuit, tho', by and by, with my claret." (Old Lady turns all manner of colours.) 


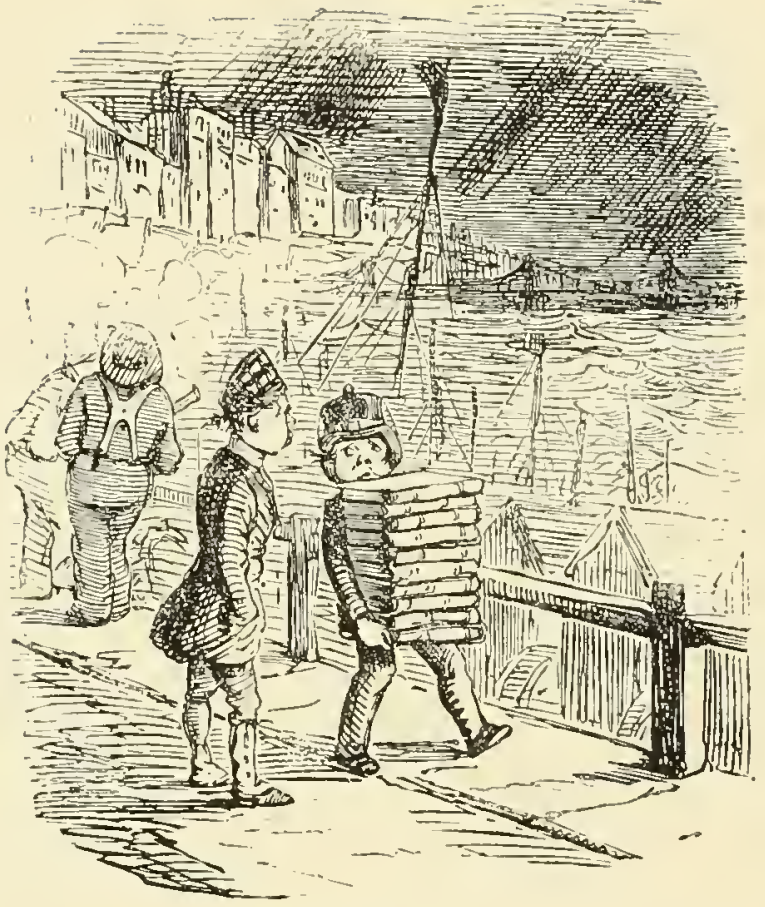

SYMPTOMS OF WET WEATHER.

Tom. "Hollo, Sam, what the juice are you carrying of ?"

Sam. " Clarissa Arlo,' for Missis."

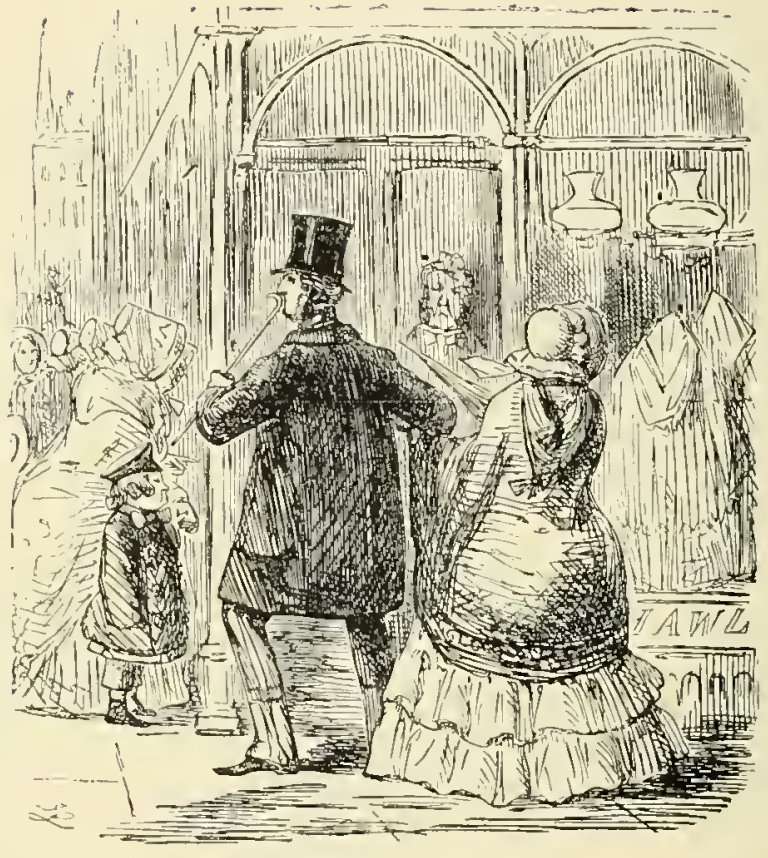

\section{CONFOUND THE SHOPS!}

Mrs. - . " oh! do look here, dear! how extremely pretty the autumn fashions are, to be sure. What a perfectly lovely little cloak!"

Ir. - (rapidly changing the subject). "Yes. Yes! beautiful! beautiful! but see, love, what a magnificent brown horse, and how splendidly that fellow sits him!" 


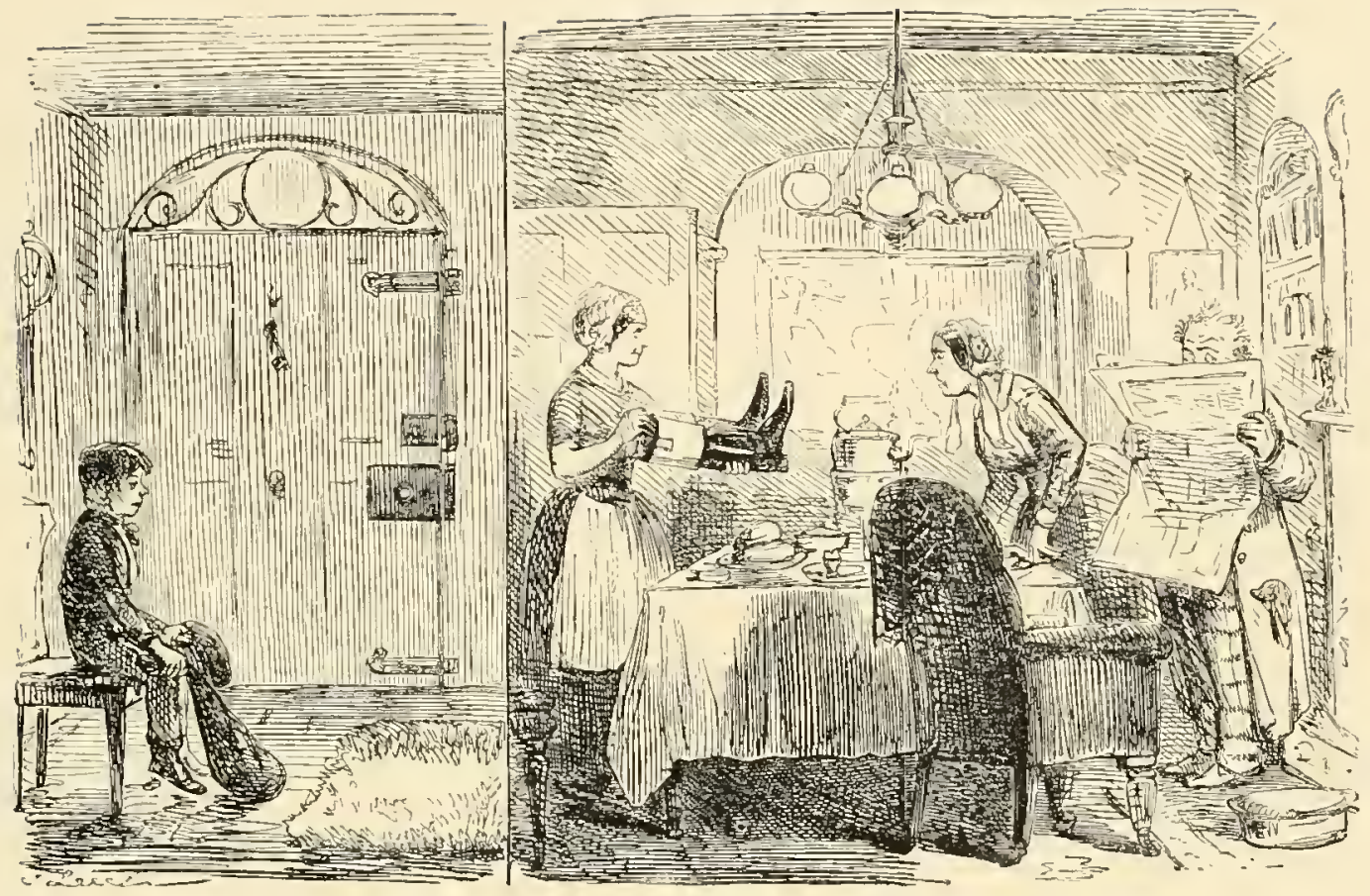

PREMONITORY SYMPTOMS OF MR. BRIGGS'S HUNTING FEVER.

Maid. "If you please, Ma'am, there's a youth in the passage as wants to know if these top boots is all right." 


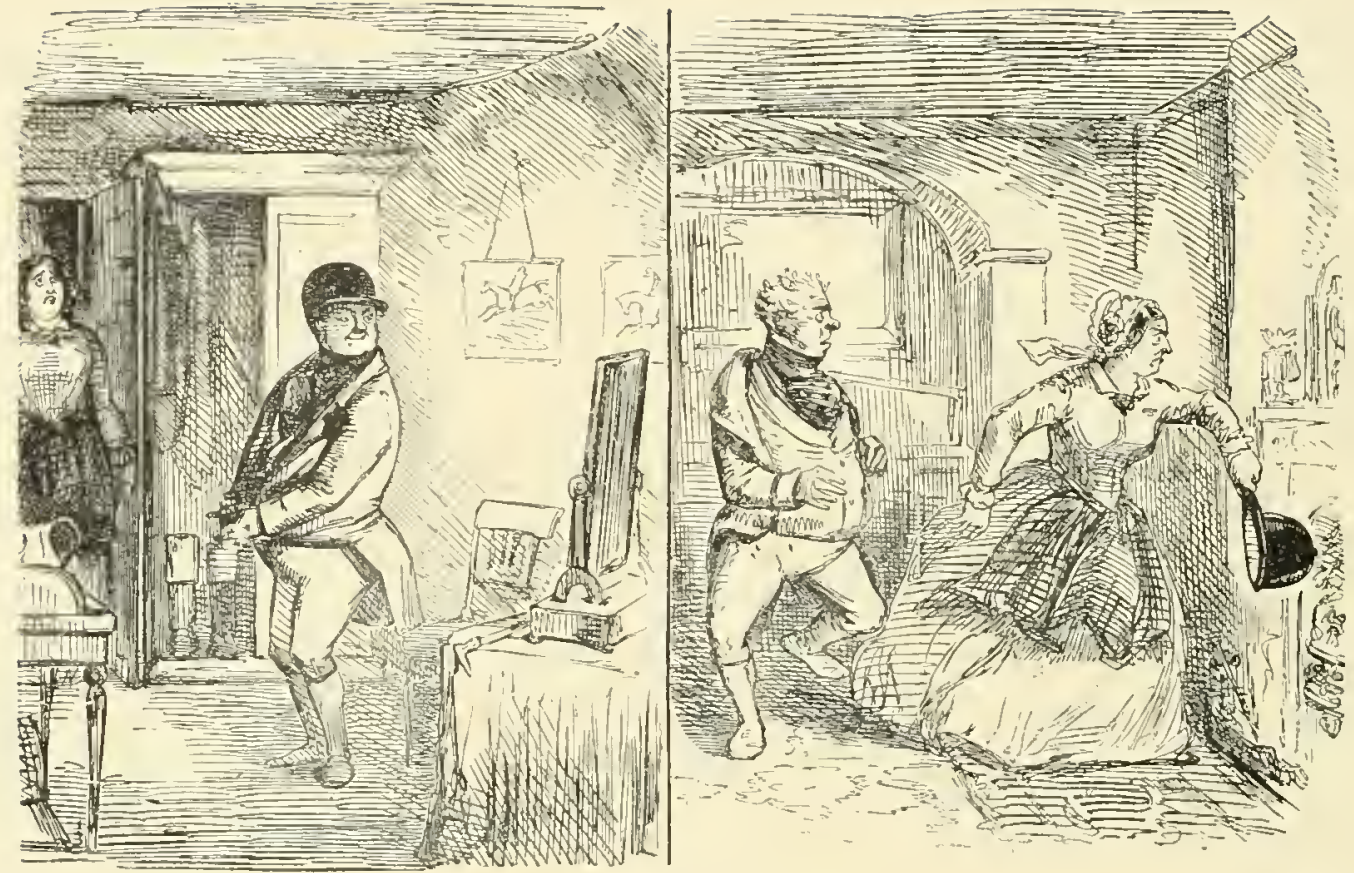

PREPARATIONS FOR HUNTING.

Mr. Briggs's hunting cap comes home, but that is really a thing Mrs. Briggs can not, and will not put up with. 


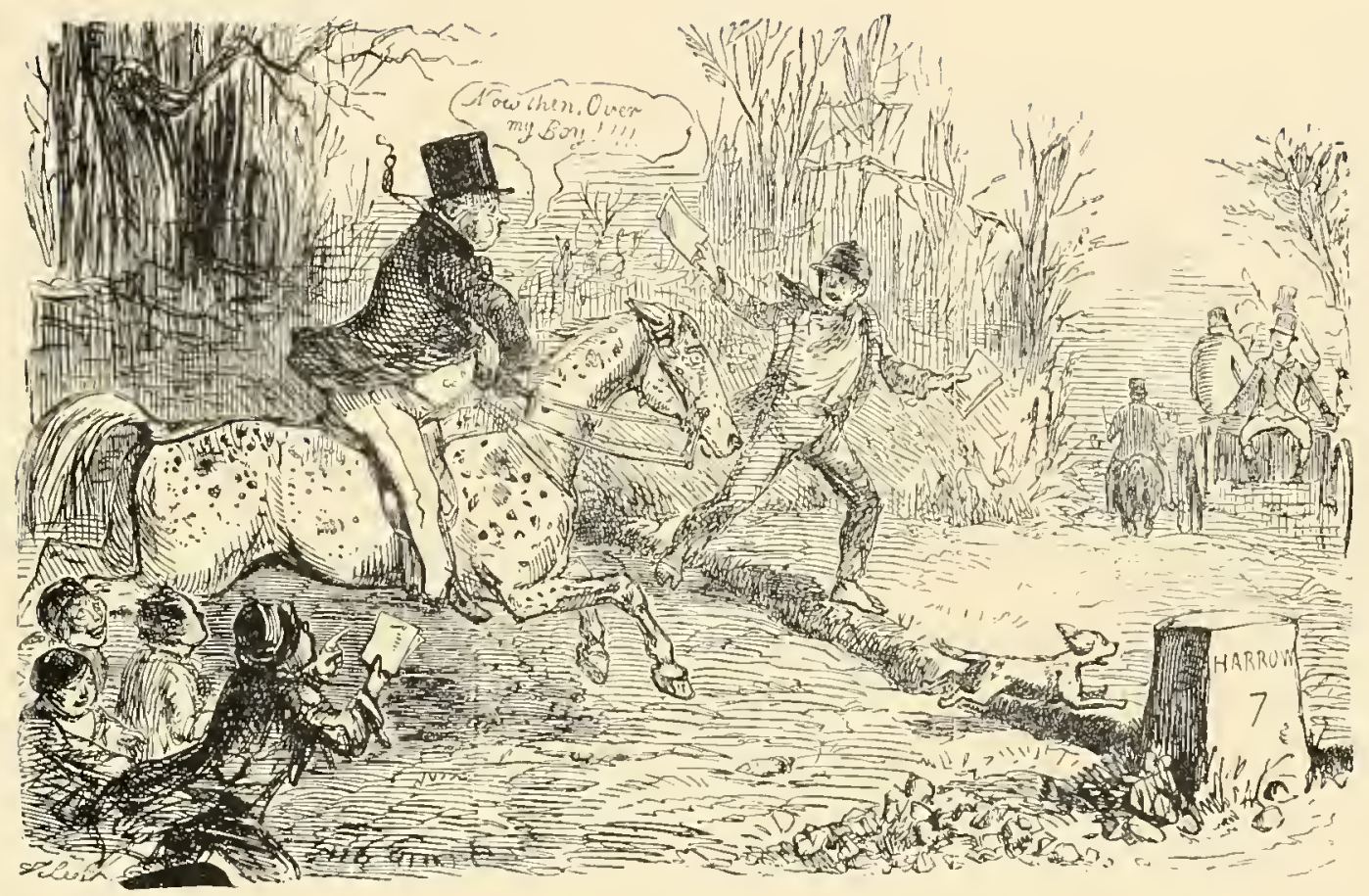

Mr. Briggs, on his way to the "Metropolitan Steeple Chase," tries whether his horse is a good one across country. He is represented riding at a brook (!). 


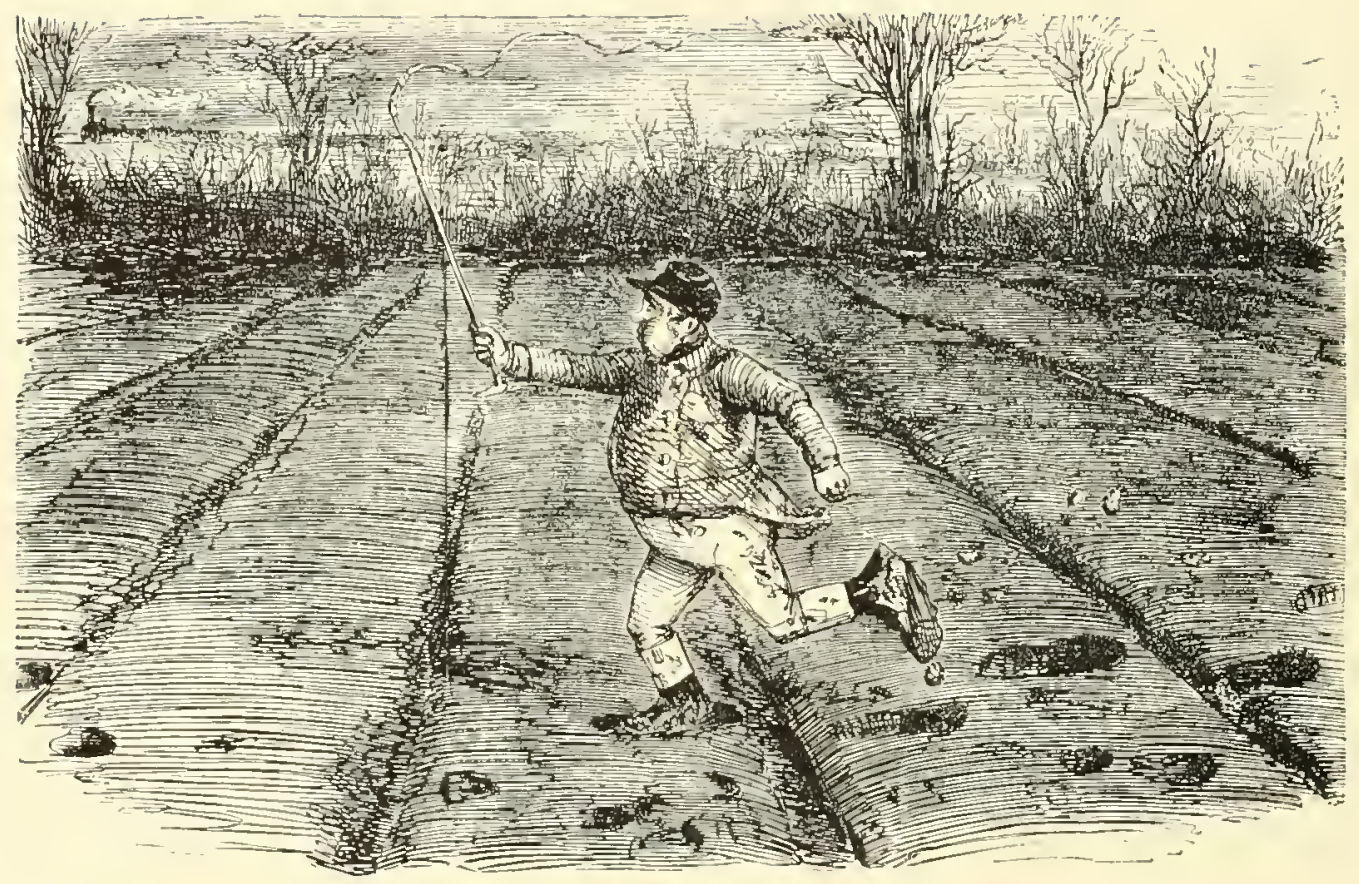

Mr. Briggs goes out for a day's hunting, and has a glorious run over a splendid country. 


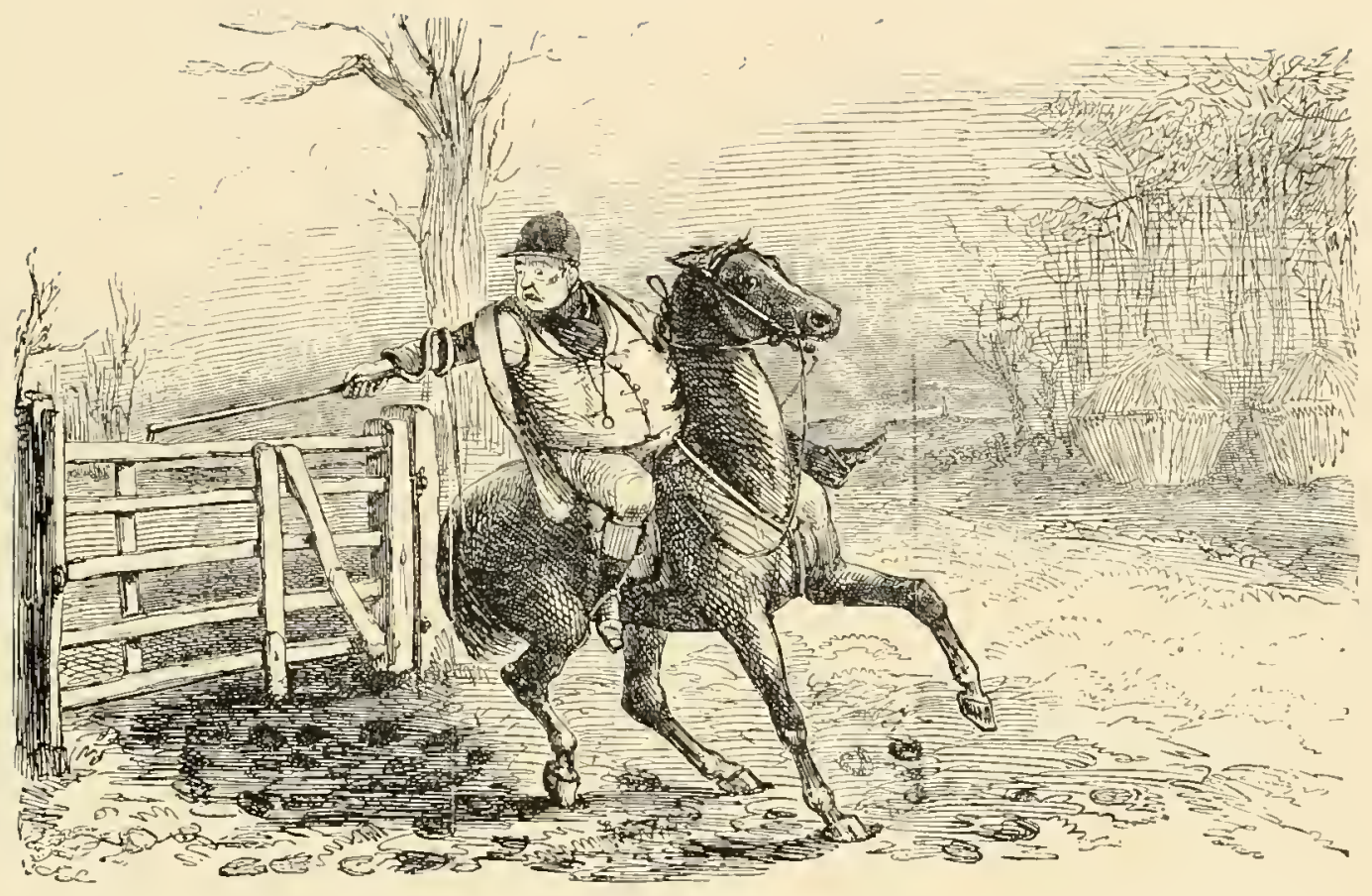

Mr. Briggs, not being good at his "fences," goes through the performance of opening a gate. 


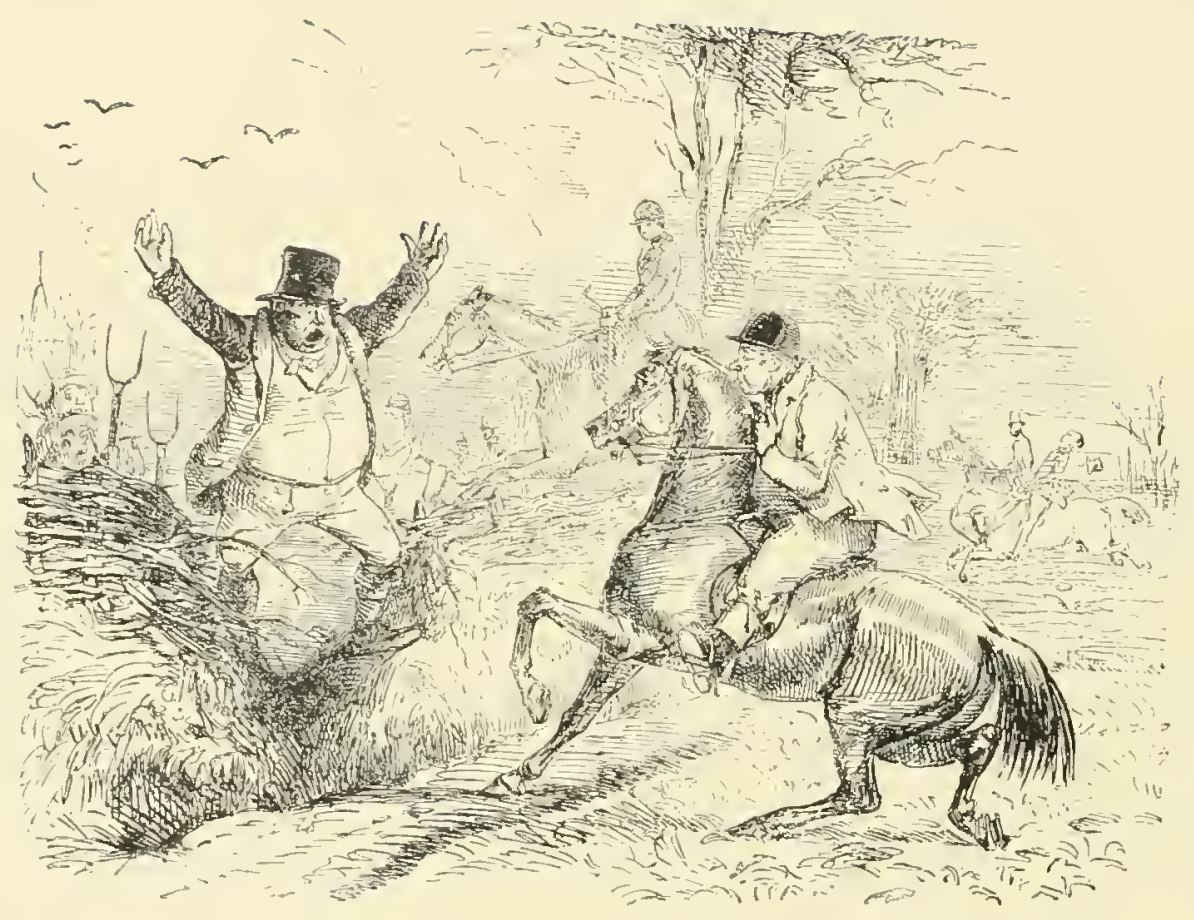

MR. BRIGGS HAS ANOTHER DAY WITH THE HOUNDS.

Mr. Briggs can't bear flying leaps, so he makes for a gap--which is immediately filled by a frantic protectionist, who is vowing that he will pitchfork Mr. B. if he comes "galloperravering " over his fences-dang'd if he doan't. 


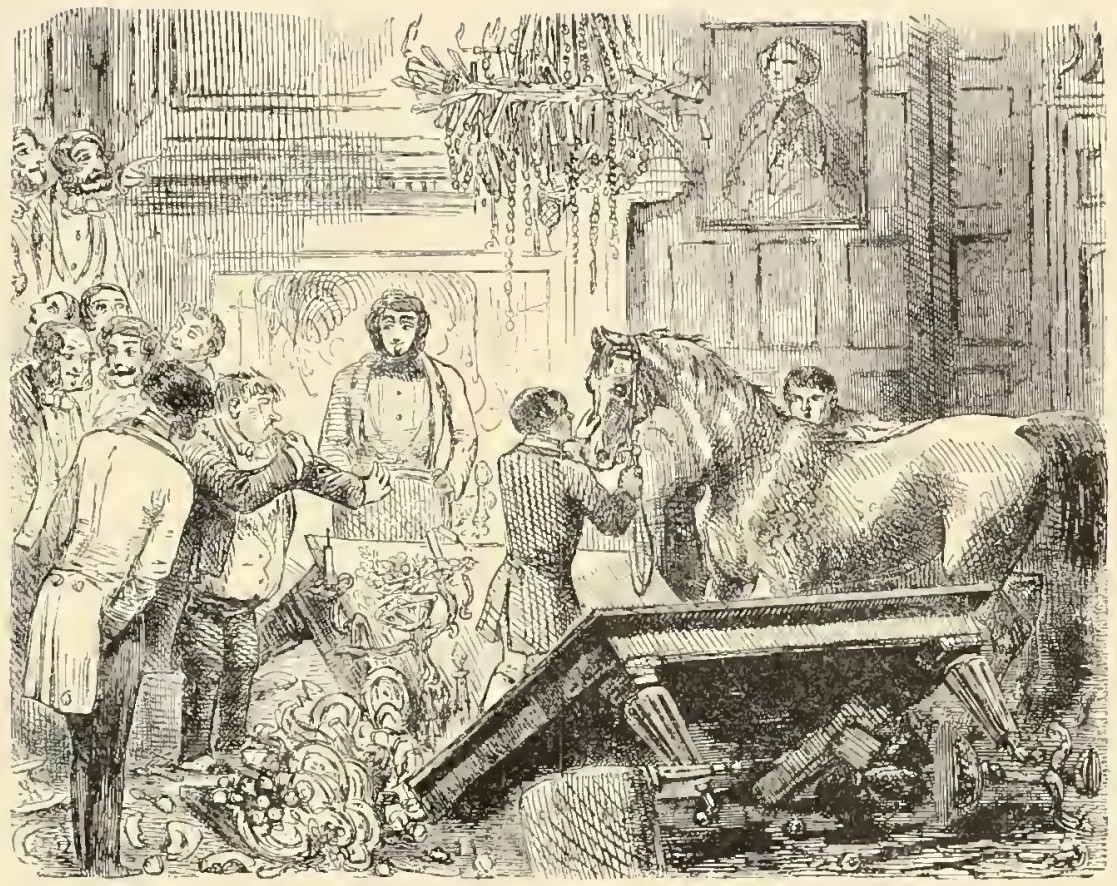

Mr. Briggs, stimulated by the accounts in the newspapers of the daring feat of horsemanship at Aylesbury, and excited by Mr. Haycock's claret, tries whether he also can ride over a dining-room table. 


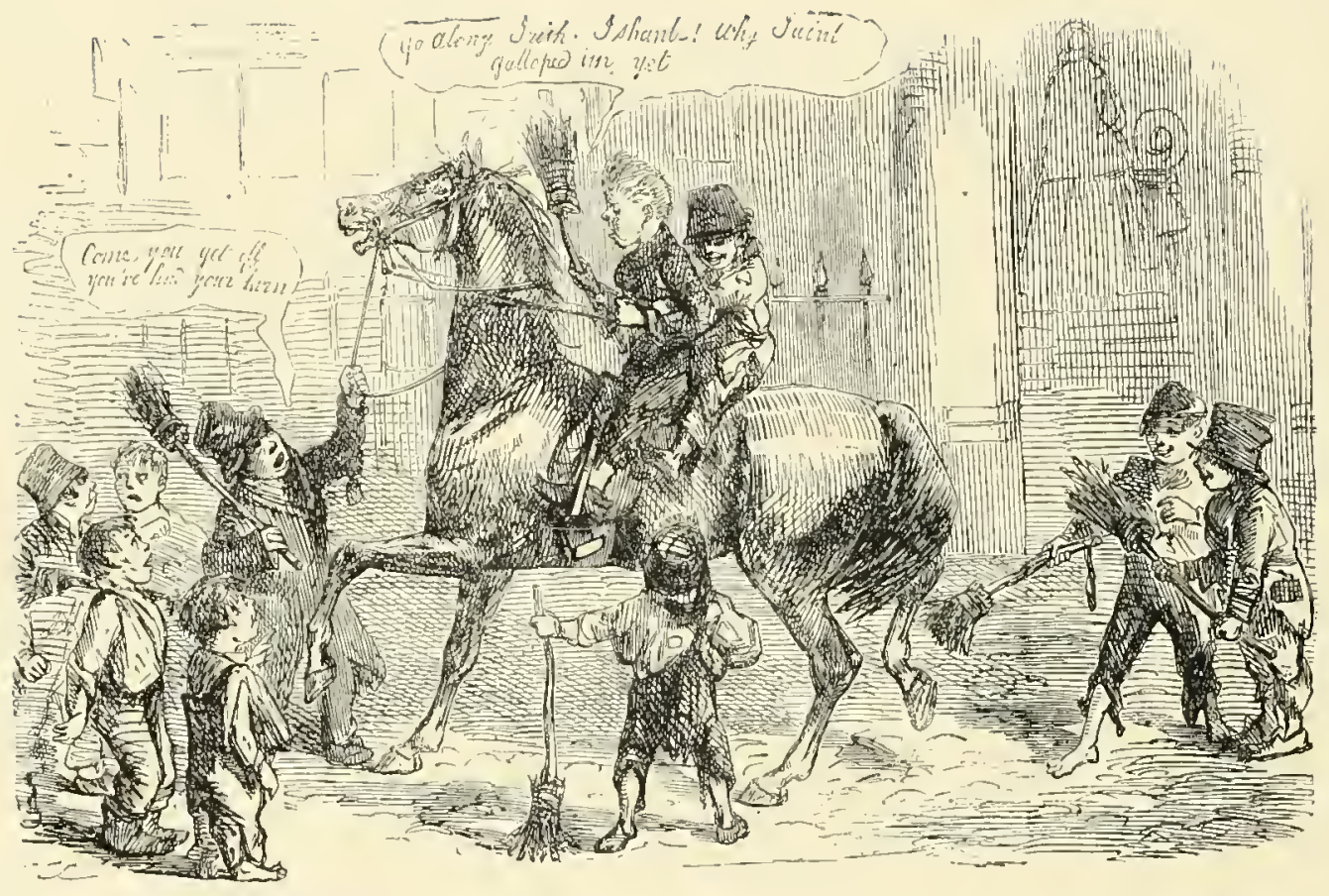

Mr. Briggs has gone to the exhibition.-A boy holds his horse in the meantime. 


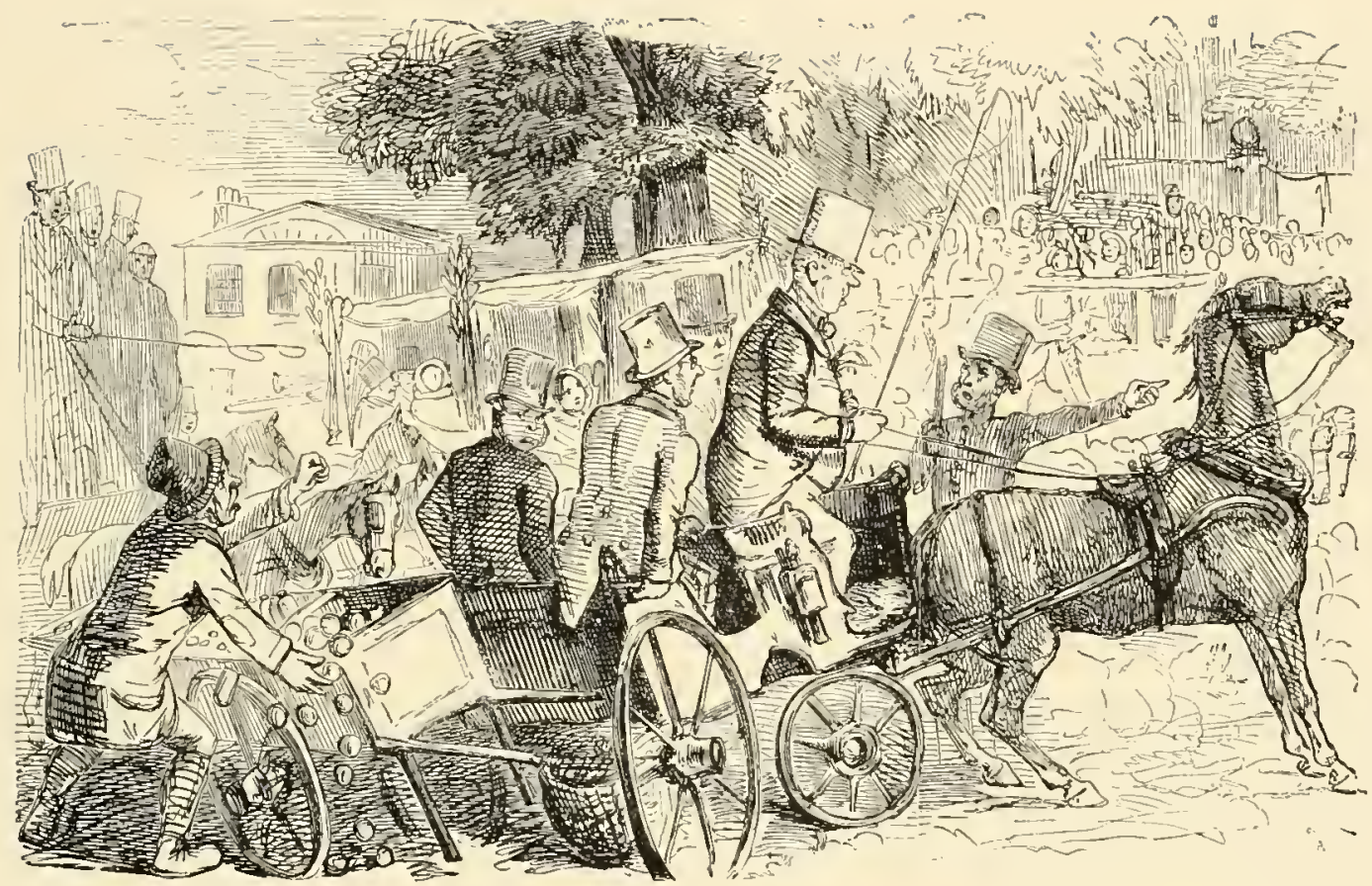

Mr. Briggs puts his horse in harness, and drives a few friends quietly down to the Derby. 


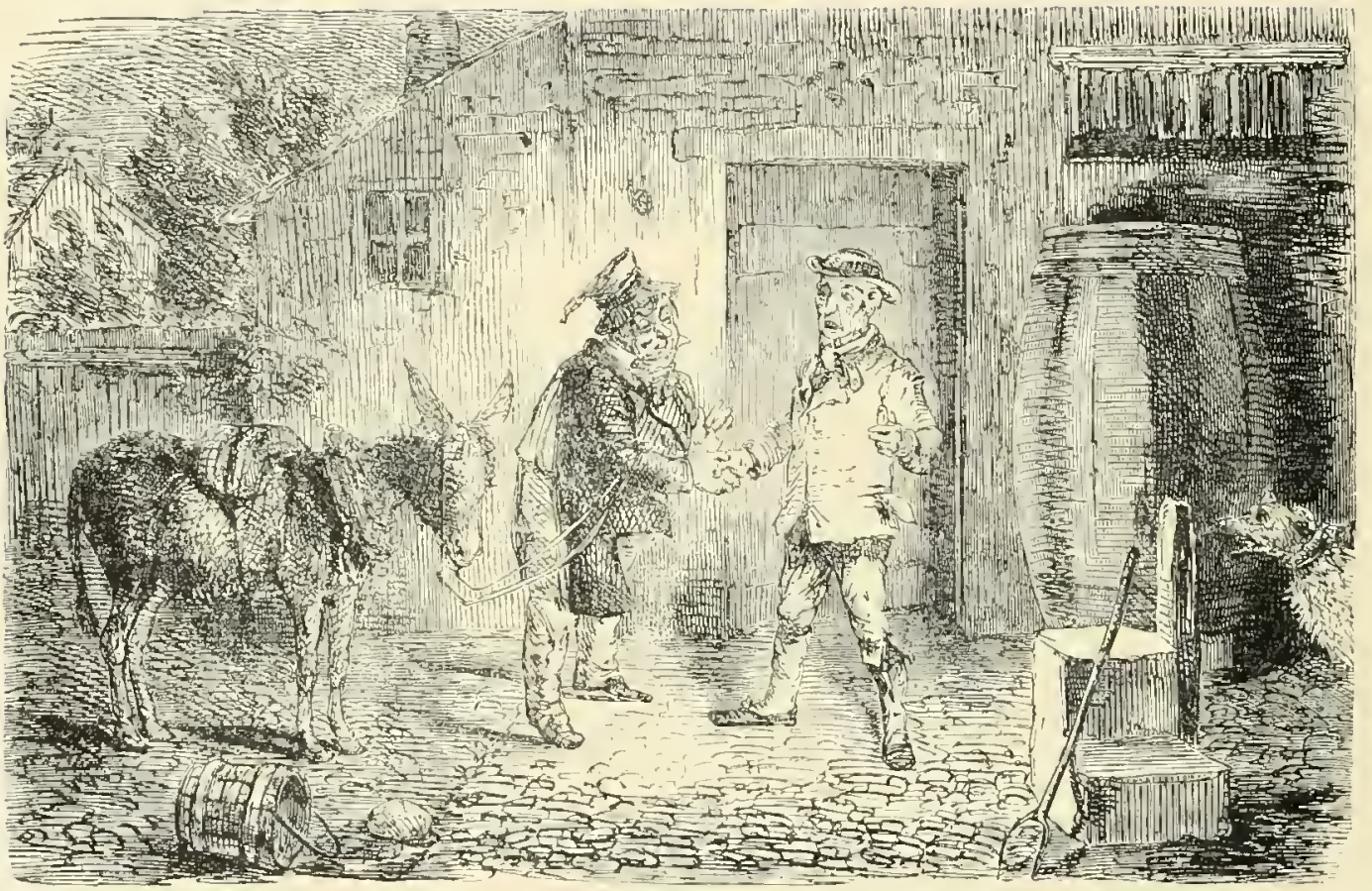

On his return from the races, he assures his man that he's a most "ekshellent servant "-that the mare never carried him better. He also tells him to make the mare quite "comf-able," and to be " very caref-1 of hish candle," because there's so much straw about! 


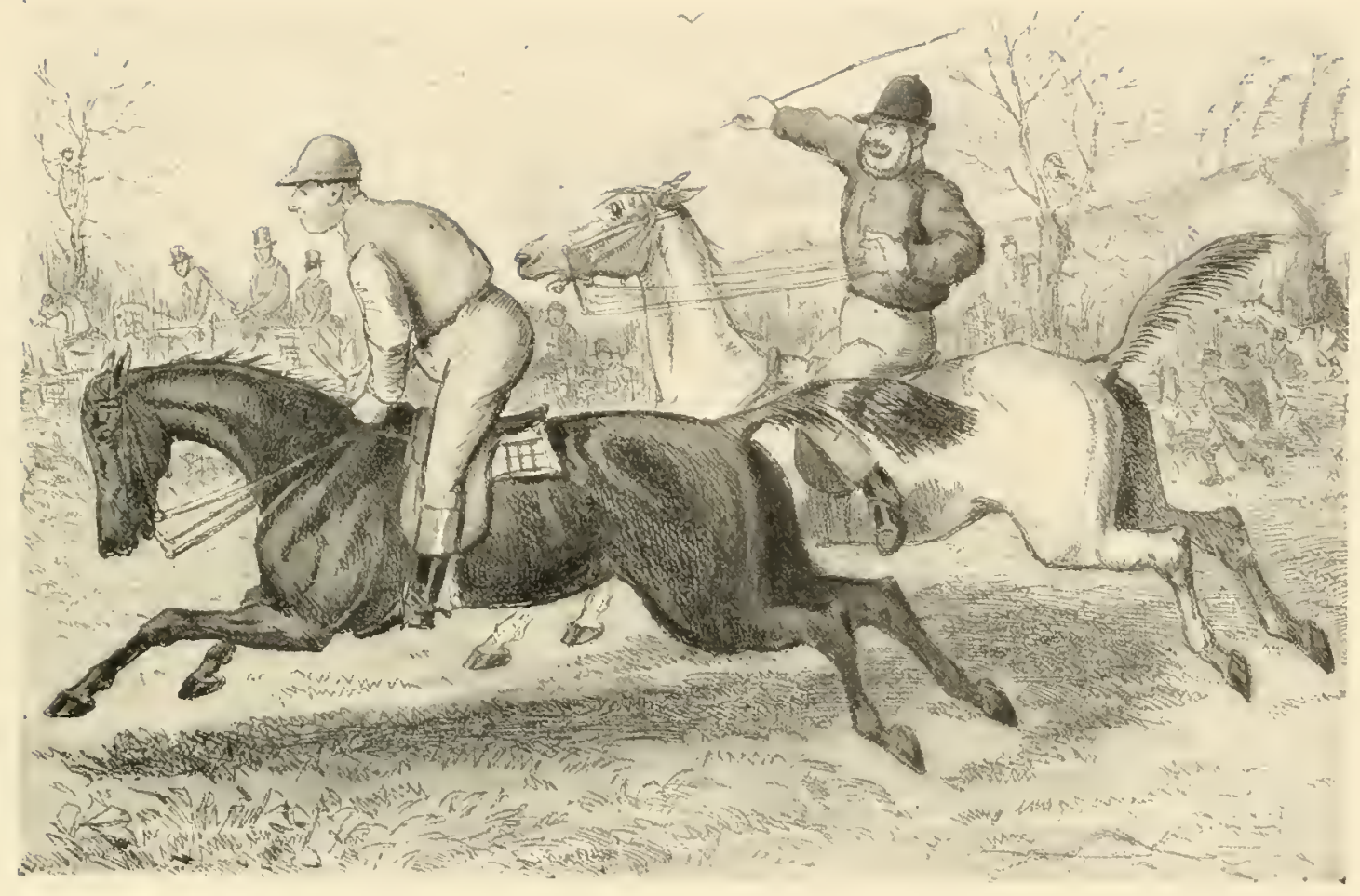

The great Match between Mr. Flintoff and Jack Rogers.-From "Isk Mammu," 


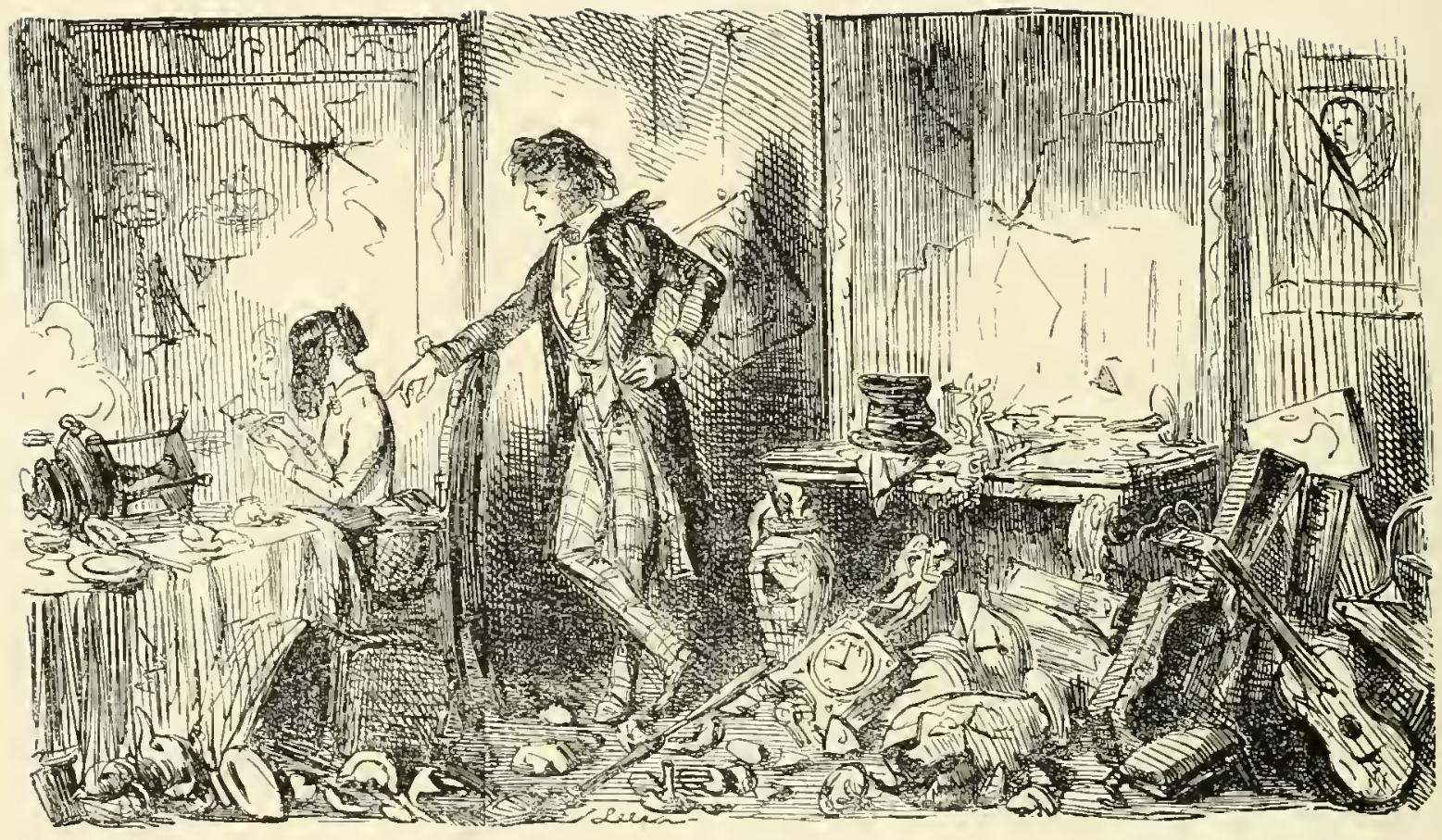

A FINE DISPOSITION.

Affectionate Husband. "Come, Polly, if I am a little irritable, it's over in a minute!!" 


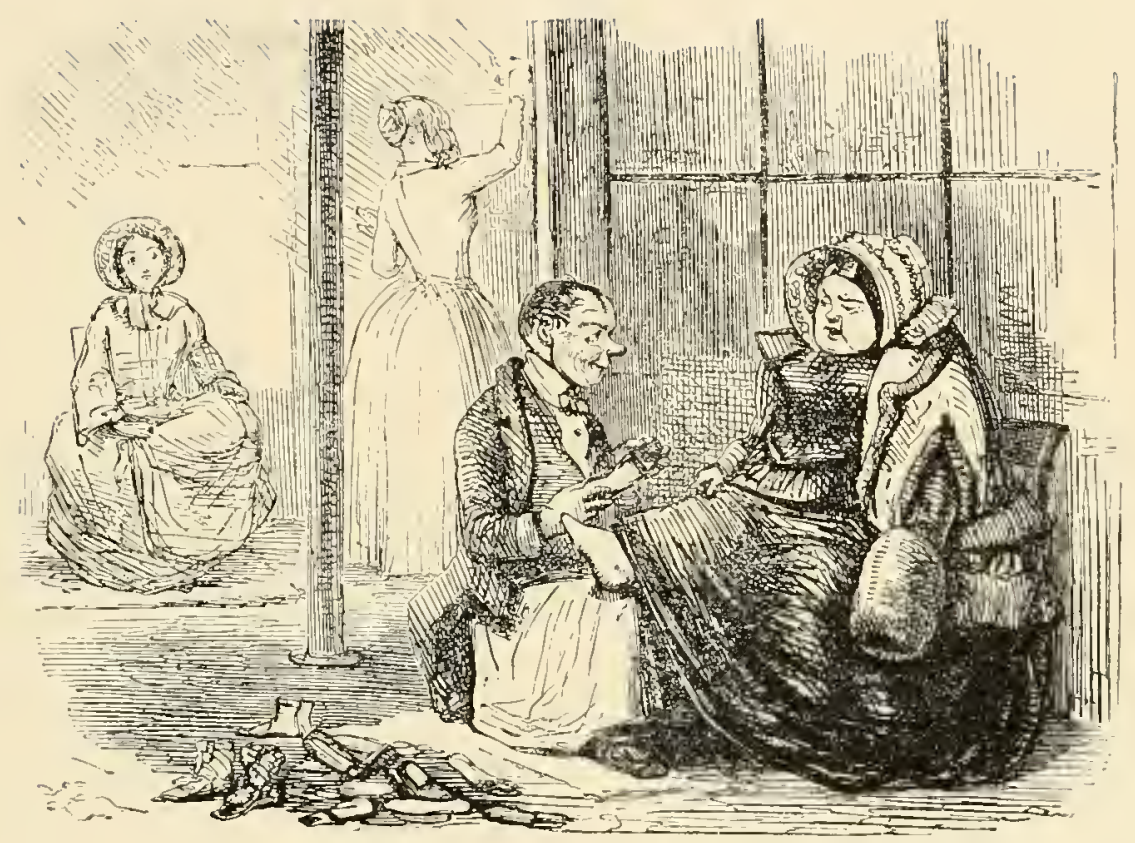

A LITTLE BIT OF HUMBUG.

Shocmaker. "I think, mum, we had better make a pair. You see, mum, yours is such a remarkable long and narrer foot!" 


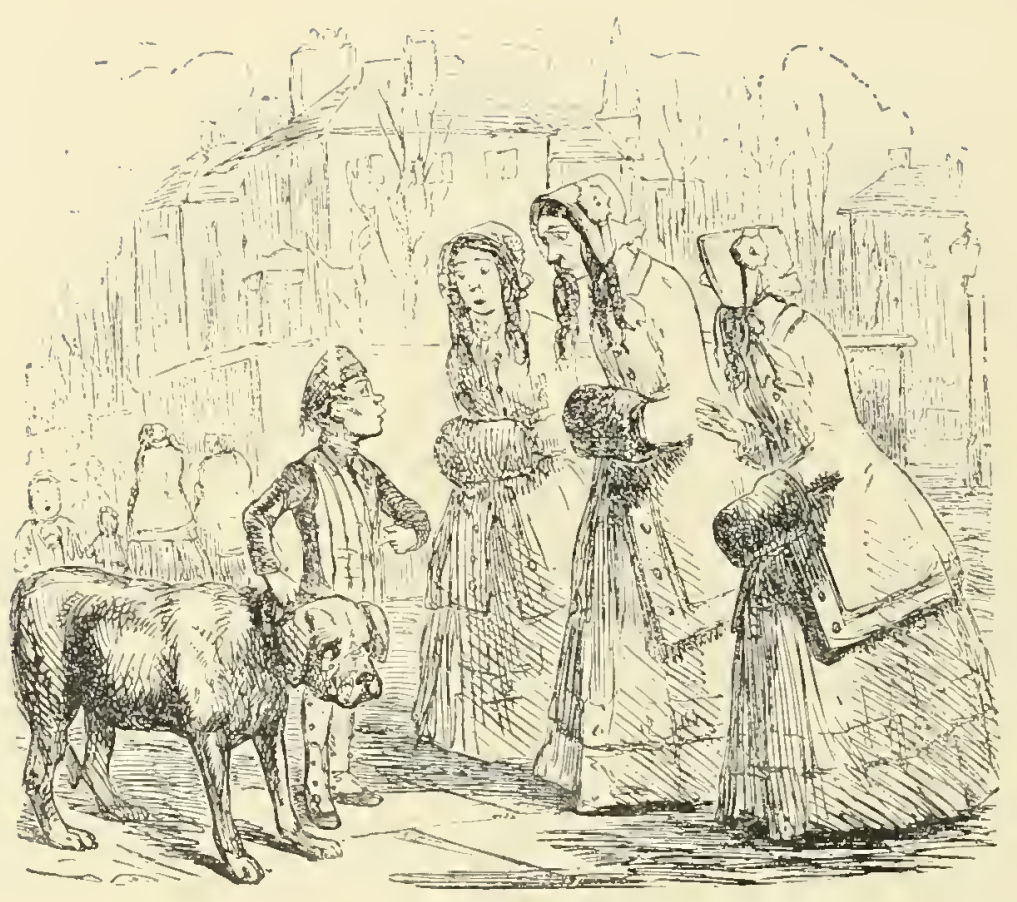

THE LOST ONE.

Boy. "If you please, M', was you a looking for a little dog?"

Young Ladics. "Yes! Oh, yes!"

Boy". "Was it a spannel, Mum?"

Foung Ladies. "Oh, yes! a most beautiful little spaniel, with very long ears."

Boy. "Ah, then, Mum, it's the same as flew at master's bir dog here, wot's bin and swallered of it." 


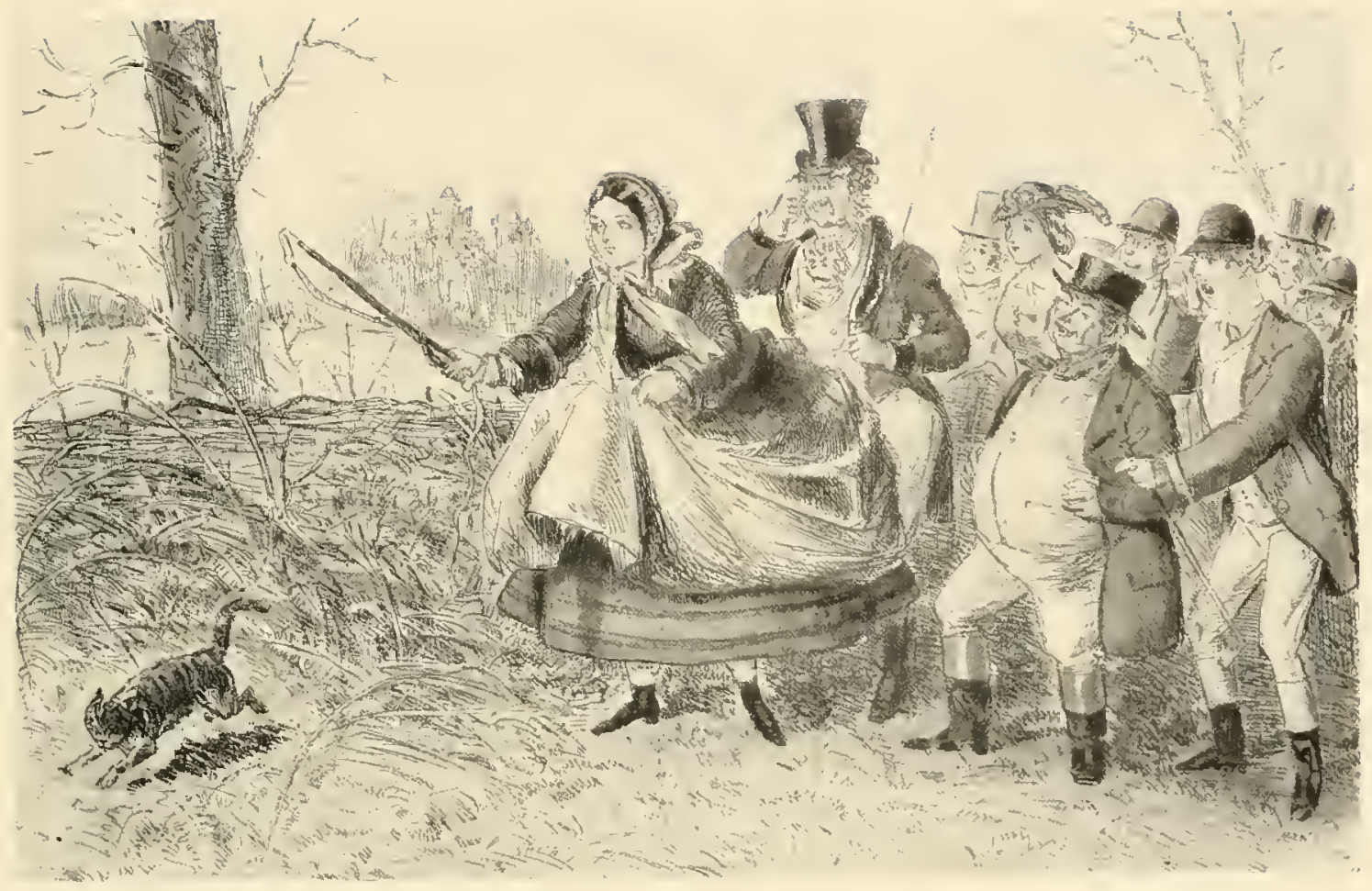

Old Wotherspoon's Hare!-From "Ask Mamma." 


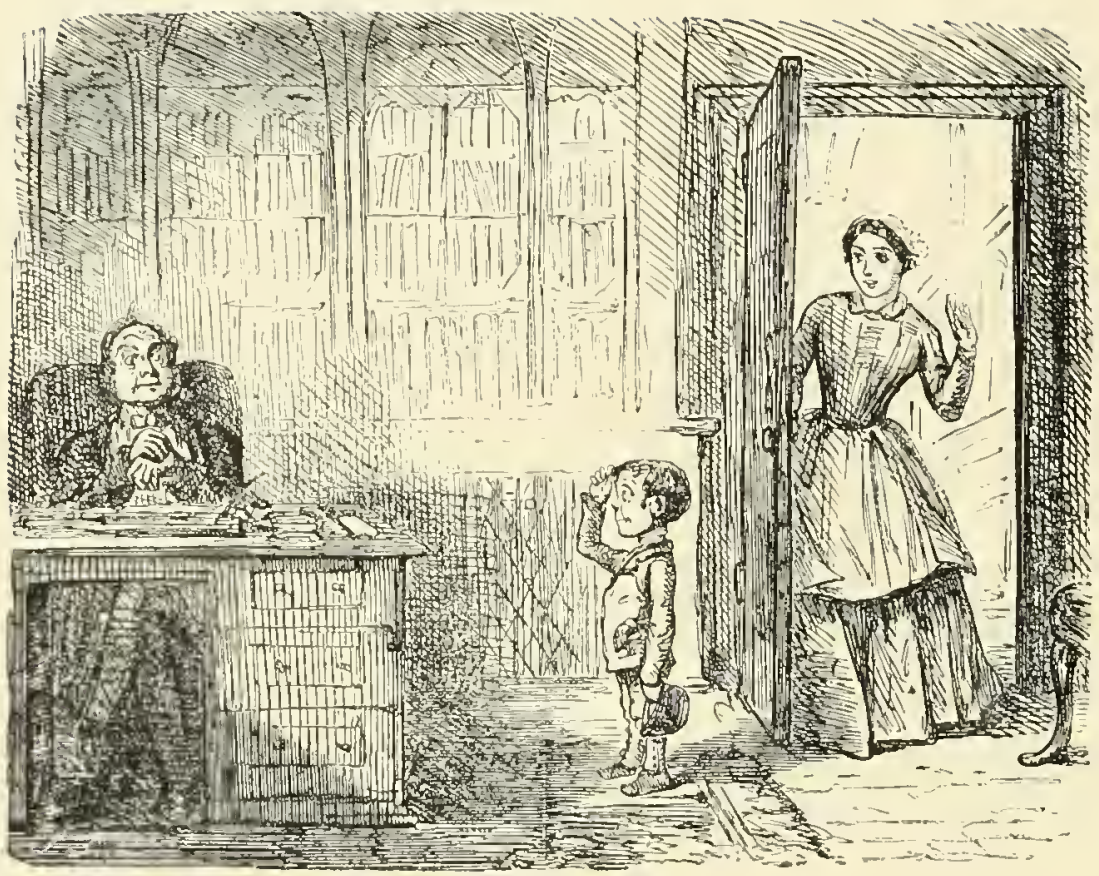

THE NEW GROOM.

Gentlcman. "Do you mean to say that you understand the care of horses?" Boy. "Well, Sir, I had ought to-for I've been amongst 'em all my life." 


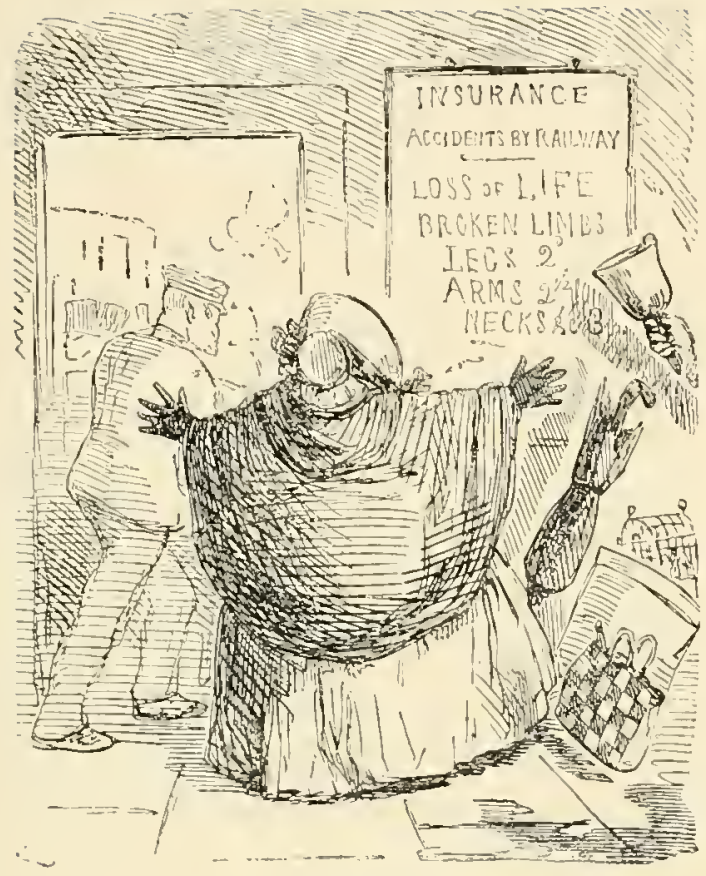

ALARMING.

The old lady is supposed (after a great effort) to have made up her mind to travel, just for once, by one "of those new fangled railways," and the first thing she beholds on arriving at the station, is the above most alarming placard.

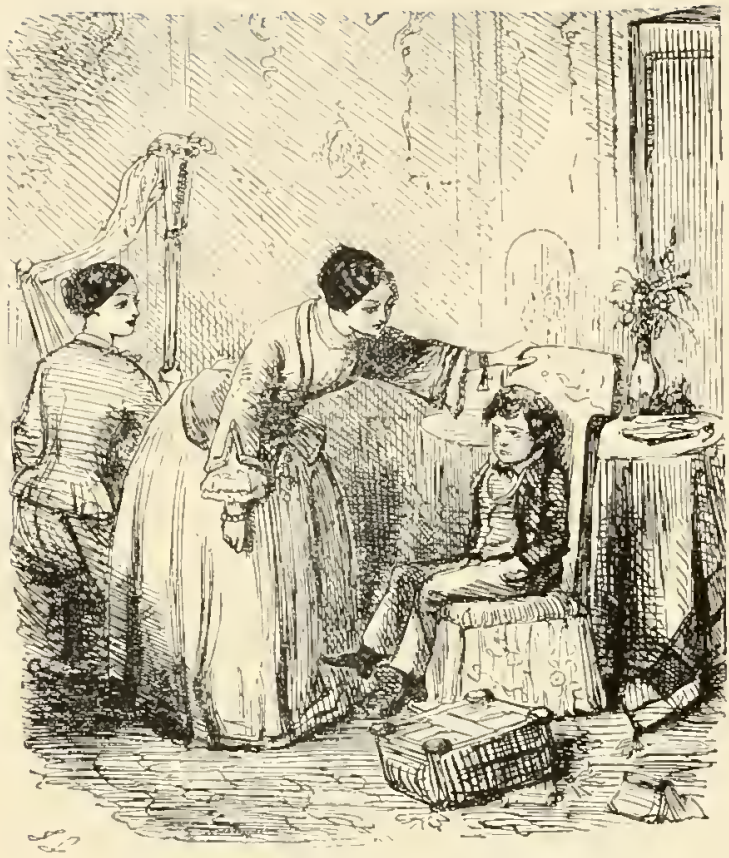

WE ALL HAVE OUR TROUBLES.

Sister Mary. "Why, Charley, dear boy, what's the matter? You seem quite miserable!"

Charley. “Ah! ain't I just! Here's ma' says I must wear turn-down collars till Christmas, and there's young Sidney Bowler (who's not half so tall as I am) has had stick-ups and white chokers for ever so long!" 


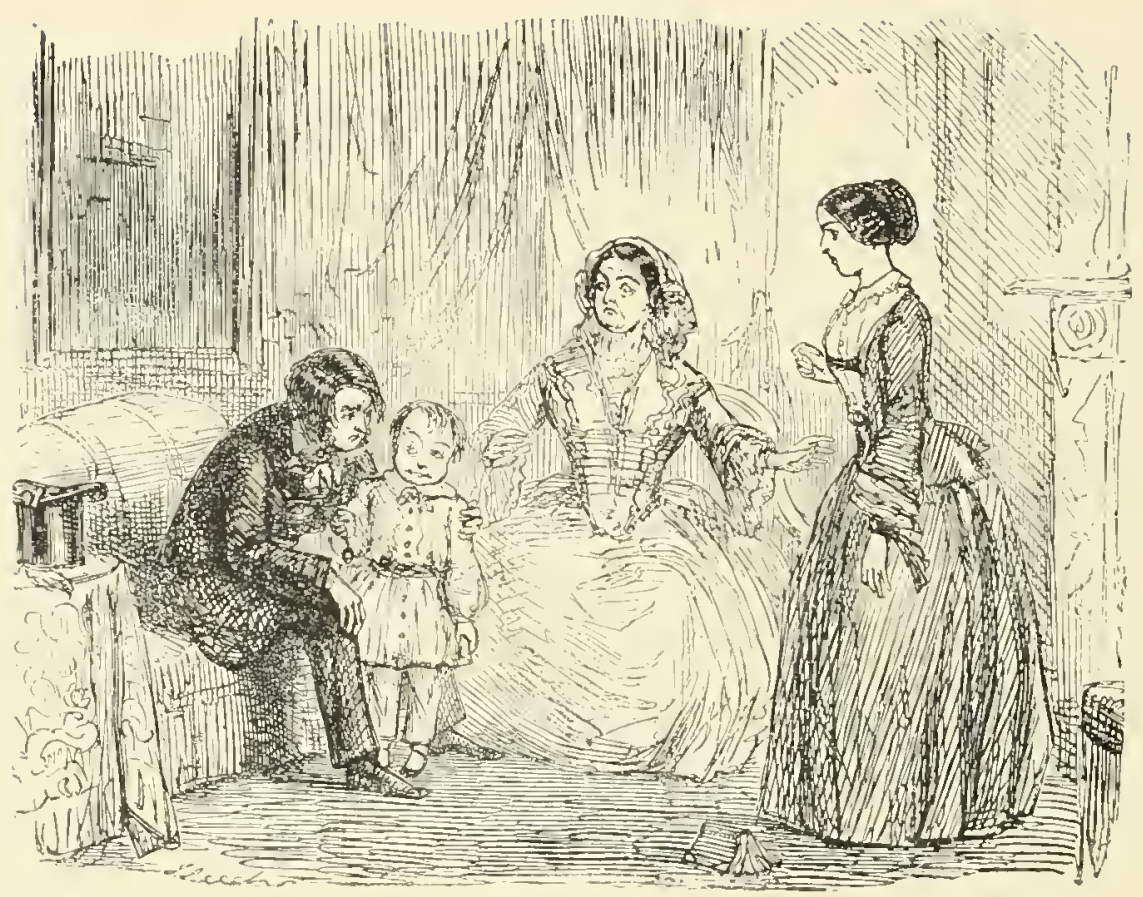

VERY ACUTE.

Mr. - "So your name is Charley, is it? Now, Charley doesn't know who I am?

Sharp Little Boy". "Oh, yes! But I do, though."

Ir. - "Well, who am I ?"

Sharp Little Boy. "Why, you're the gentleman who kissed sister Sophy in the library, on Twelf th Night, when you thought no one was there." 


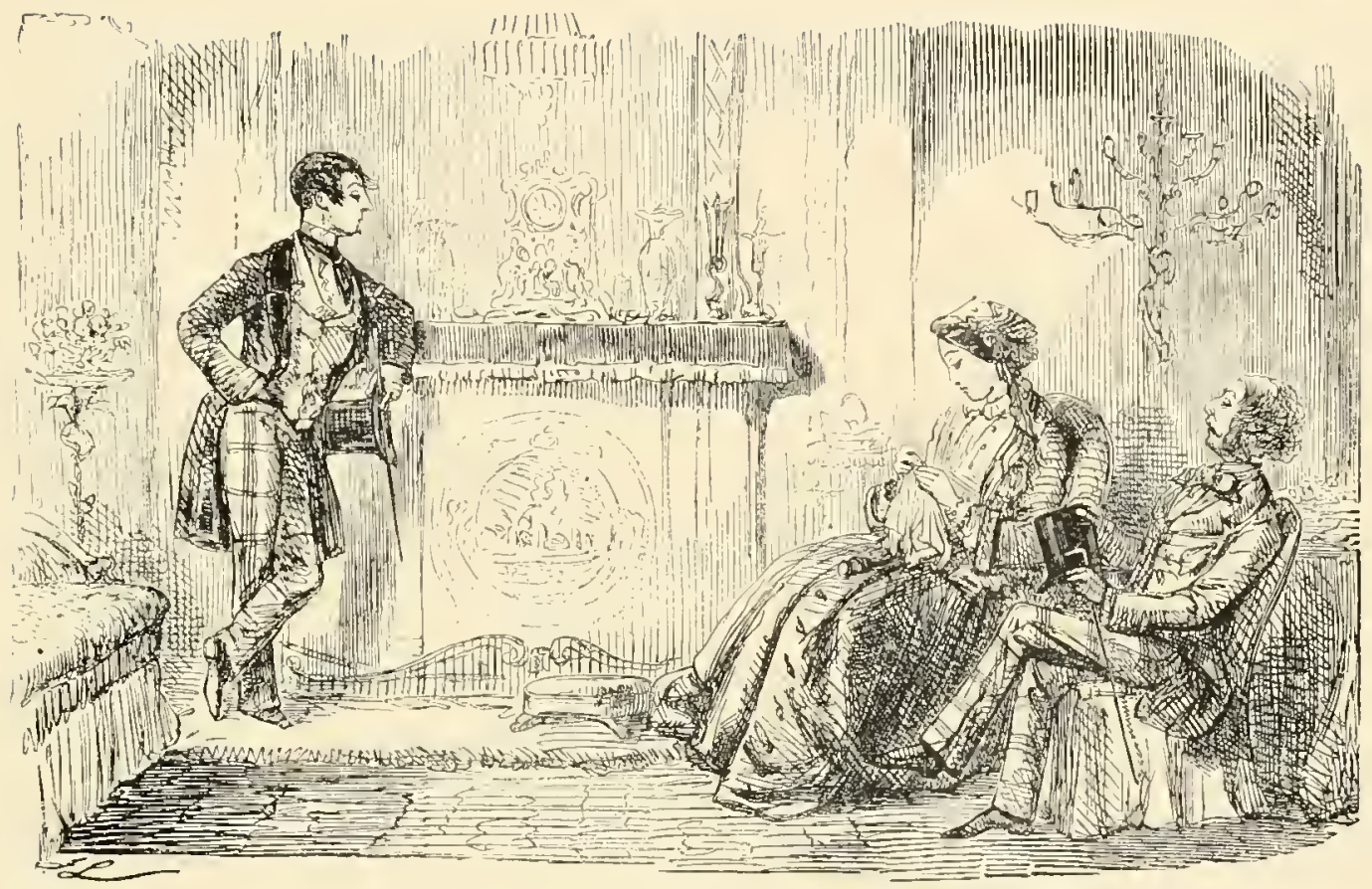

WHAT THEY SAID TO THEMSELVES.

Honourable .Ir. Fiddle. "I wish that conceited ass, Faddle, would go!"

Captain Faddle. "That stupid idiot, Fiddle, never knows when he's in the way!"

Rich I'idow'. "I shall be uncommonly glad when both of these simpletons take their departure." 


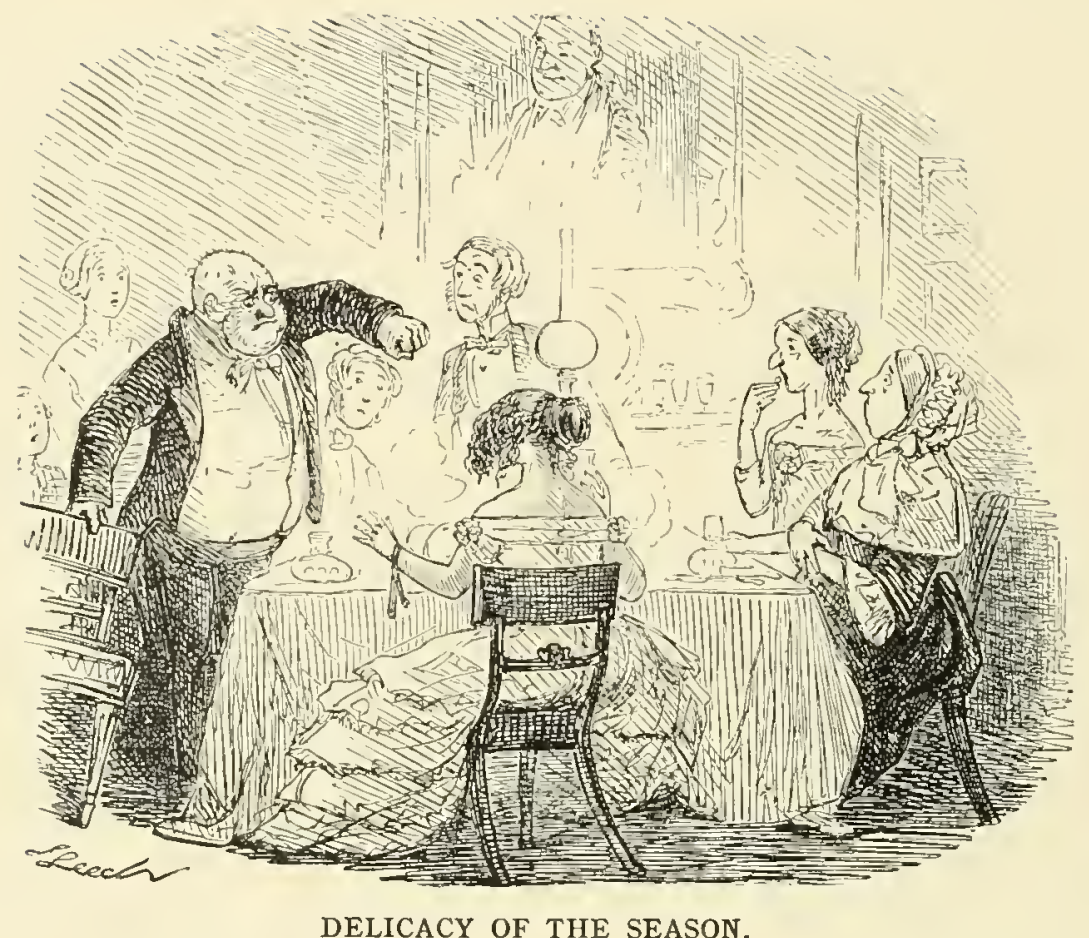

DELICACY OF THE SEASON.

Testy Old Uncle (unable to control his passion). "Really, Sir, this is quite intolerable! You must intend to insult me. For the last fourteen days, wherever I have dined, I have had nothing but saddle of mutton and boiled turkey--boiled turkey and saddle of mutton. I'll endure it no longer." (Exit Old Gont., who altors his Will.)

MORAL.

Hone ridiculons a man appears particularly a man at a grave period of life who is coer anxions about his cating and drinking. 


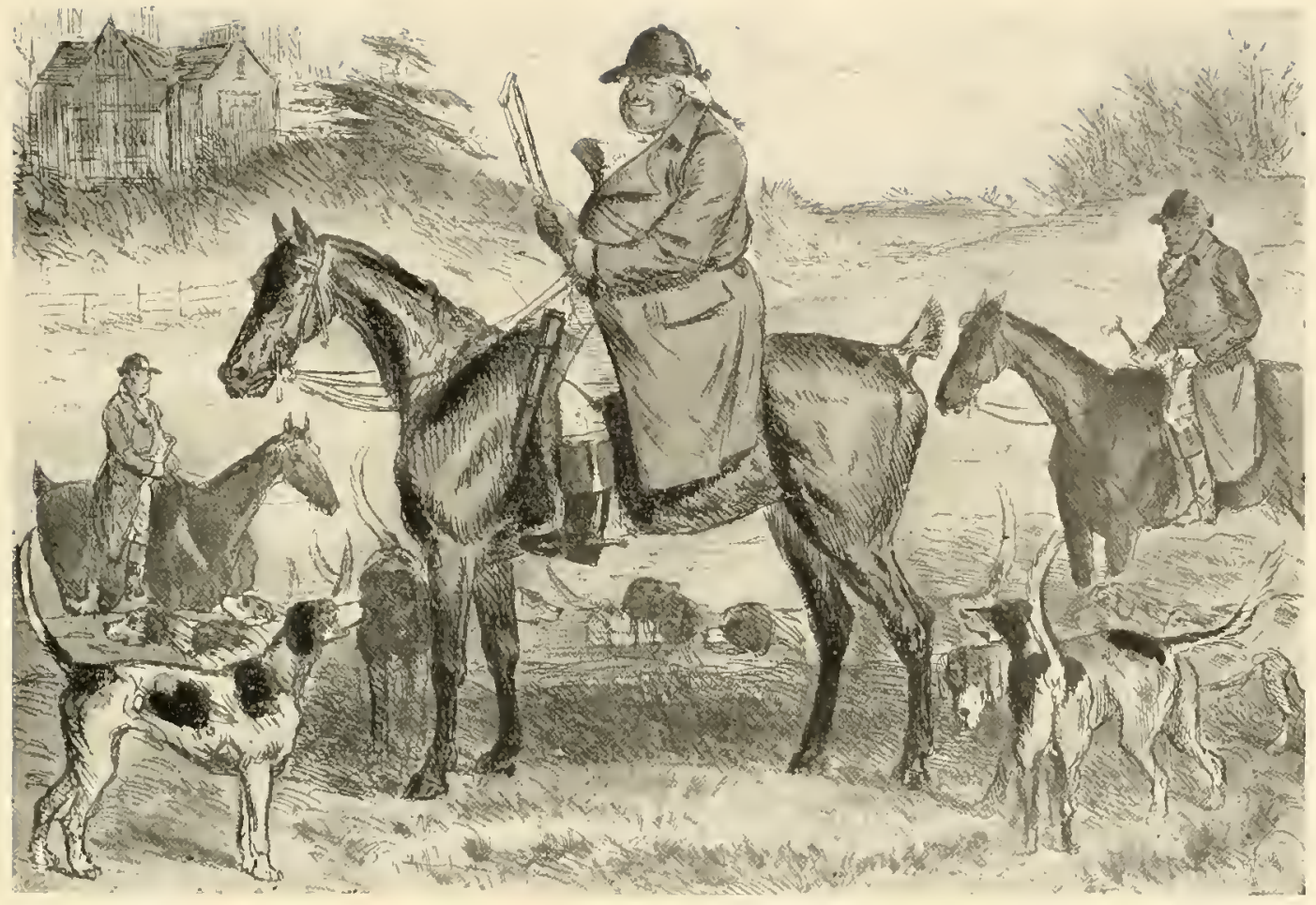

Simon Heavy-side and his Hounds.-From "Mr. Fuccy Romford's Hounds." 


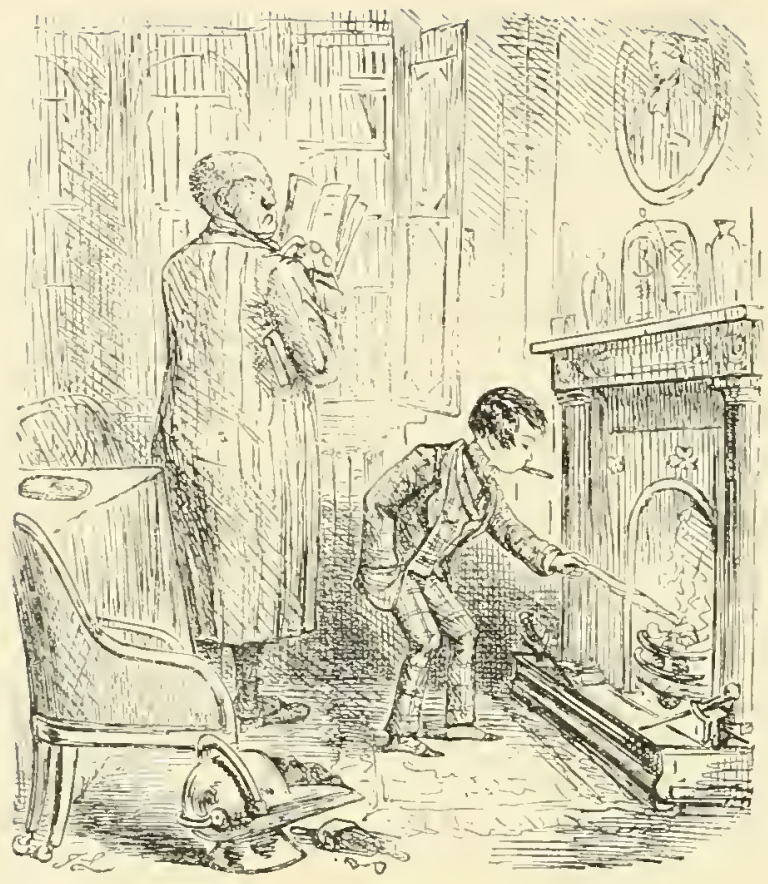

SOUND ADVICE

Master Tom. "Have a weed, Grand'pa?"

Gran"pa. "A what! Sir?"

Master Tom. "A weed! - A cigar, you know."

Gran"pa. "Certainly not, Sir. I never smoked in my life."

Waster Tom. "Ah! then I wouldn't advise you to begin." 


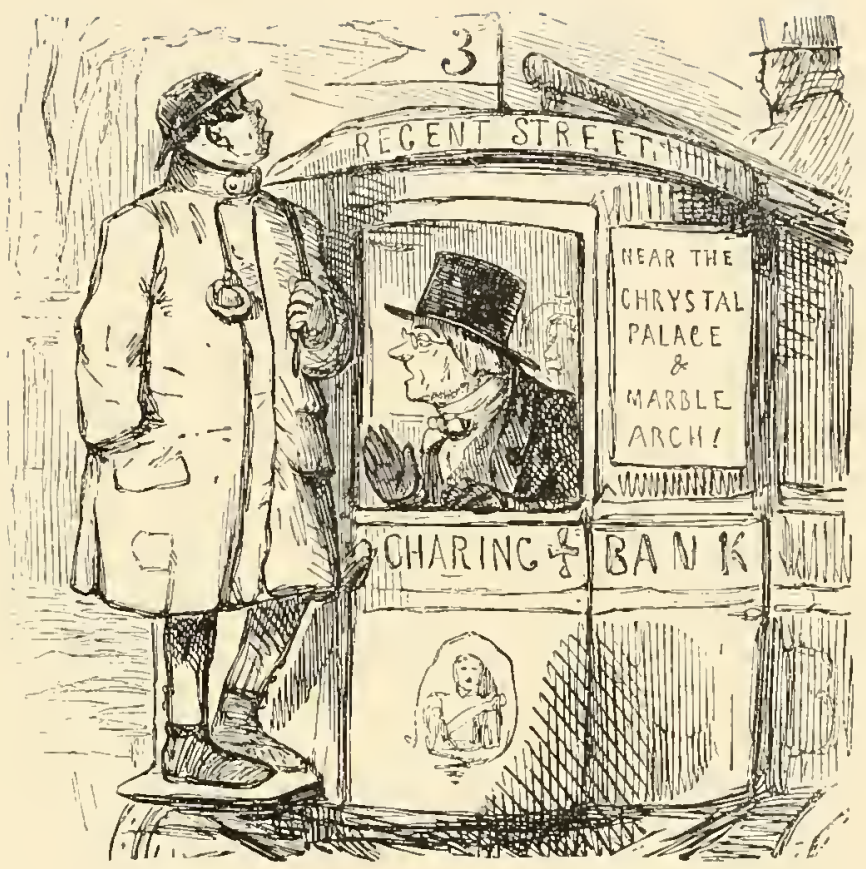

DID YOU EVER?

Old Gentlcman (politcly). " $\mathrm{Oh}$, conductor! I shall feel greatly obliged to you if you would proceed, for I have an appointment in the Strand, and I am afraid I shall be too late."

Conductor (slamming the door). "Go on, Jim! here's an old cove a cussin' and a swearing like any think! ! !" 


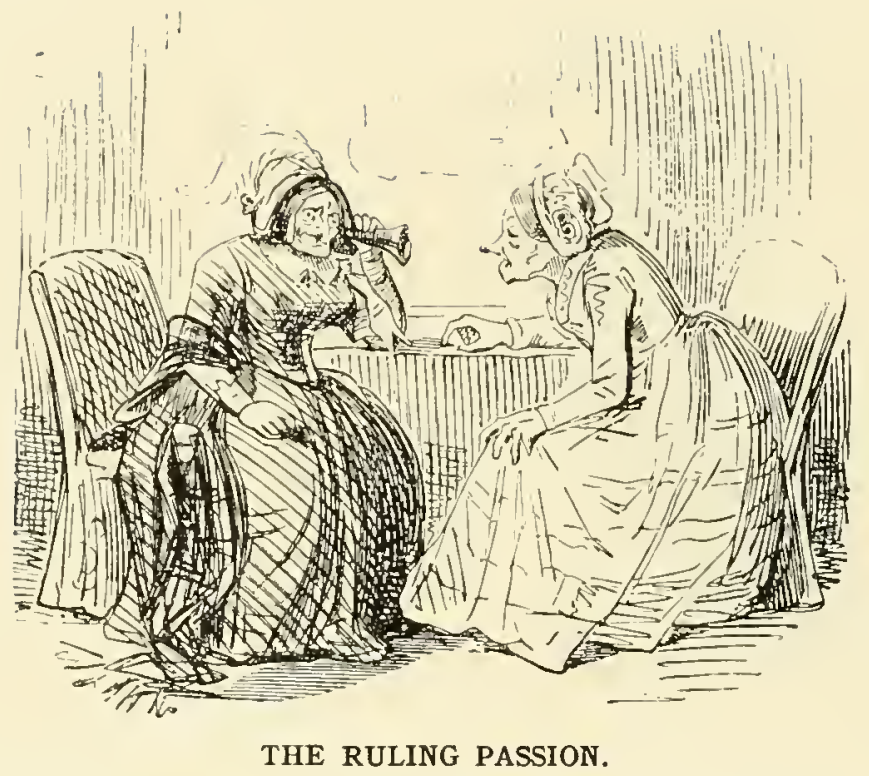

"Now, tell me, dear, is there anything new in the fashions?" 


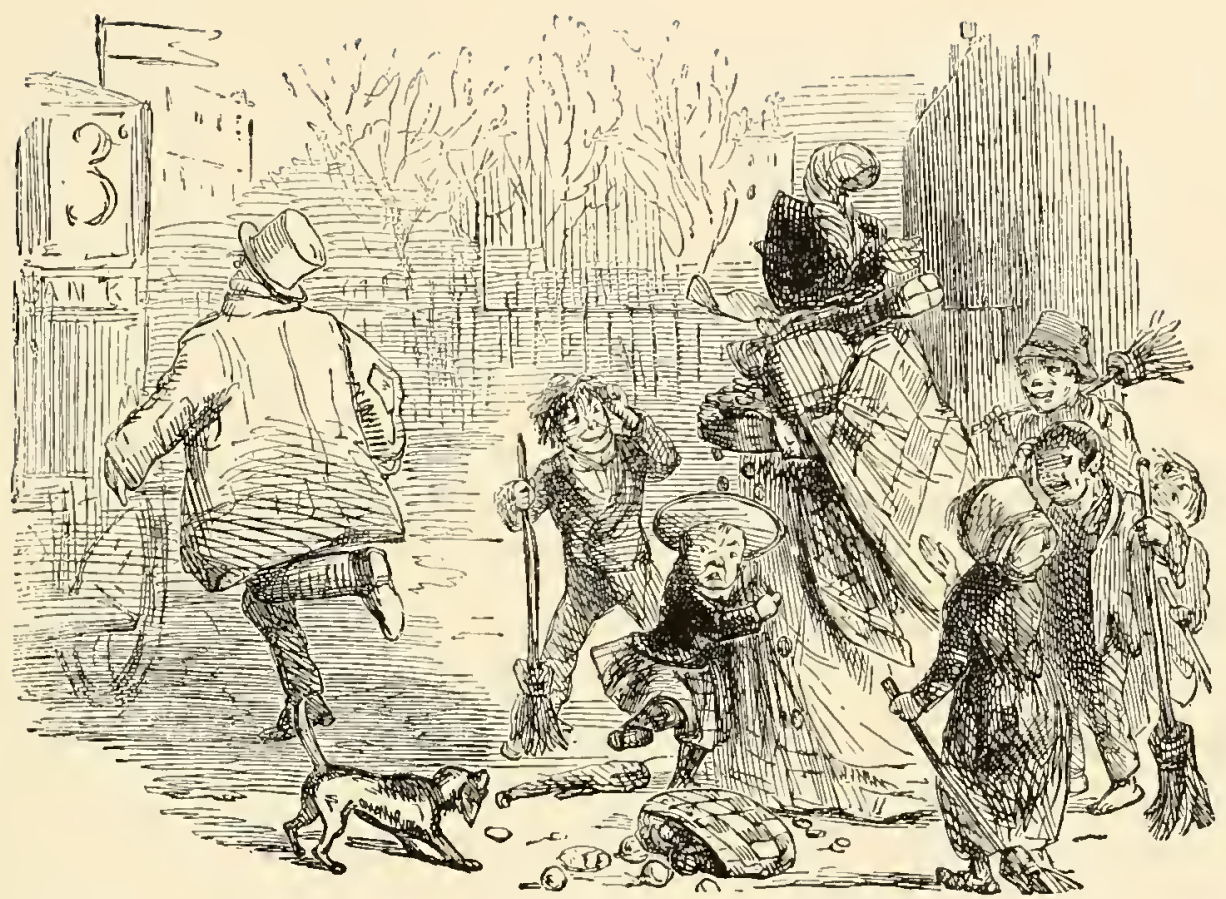

TAKING CHANGE

Conductor. "All right, Jim. Push along, I've served the old gal out this time."

Old Lady. "Here, stop! conductor! I won't take change for a five-shilling piece in half-pence-that I won't! Here, police! conductor!" \&c. 


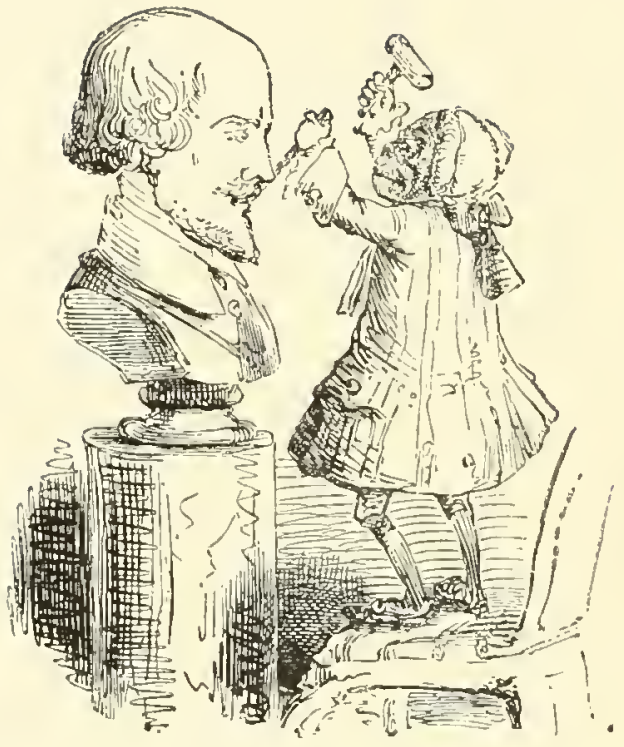

CIBBER AND SHAKESPEARE.

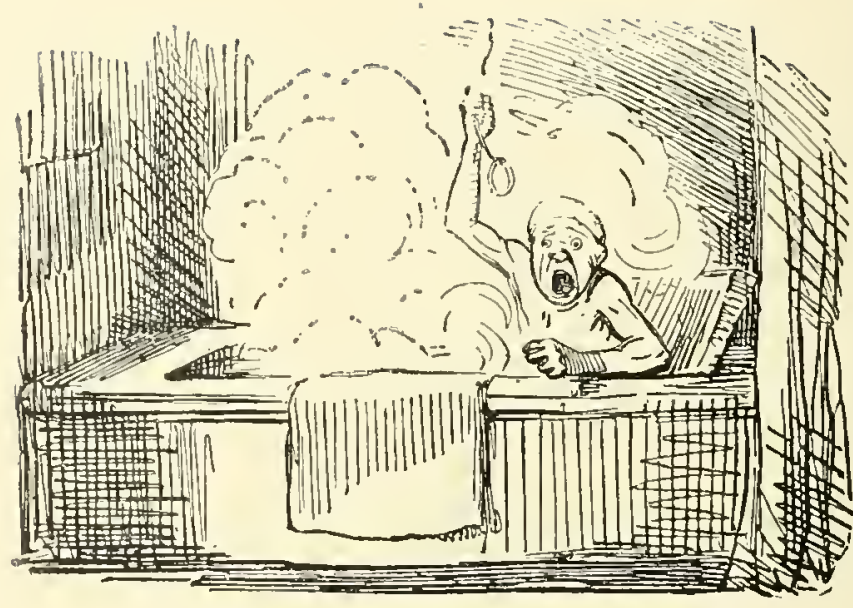

NOTHING LIKE WARM BATHING.

"Hollo! hi! here! somebody! I've turned on the hot water, and I can't turn it off again!" 


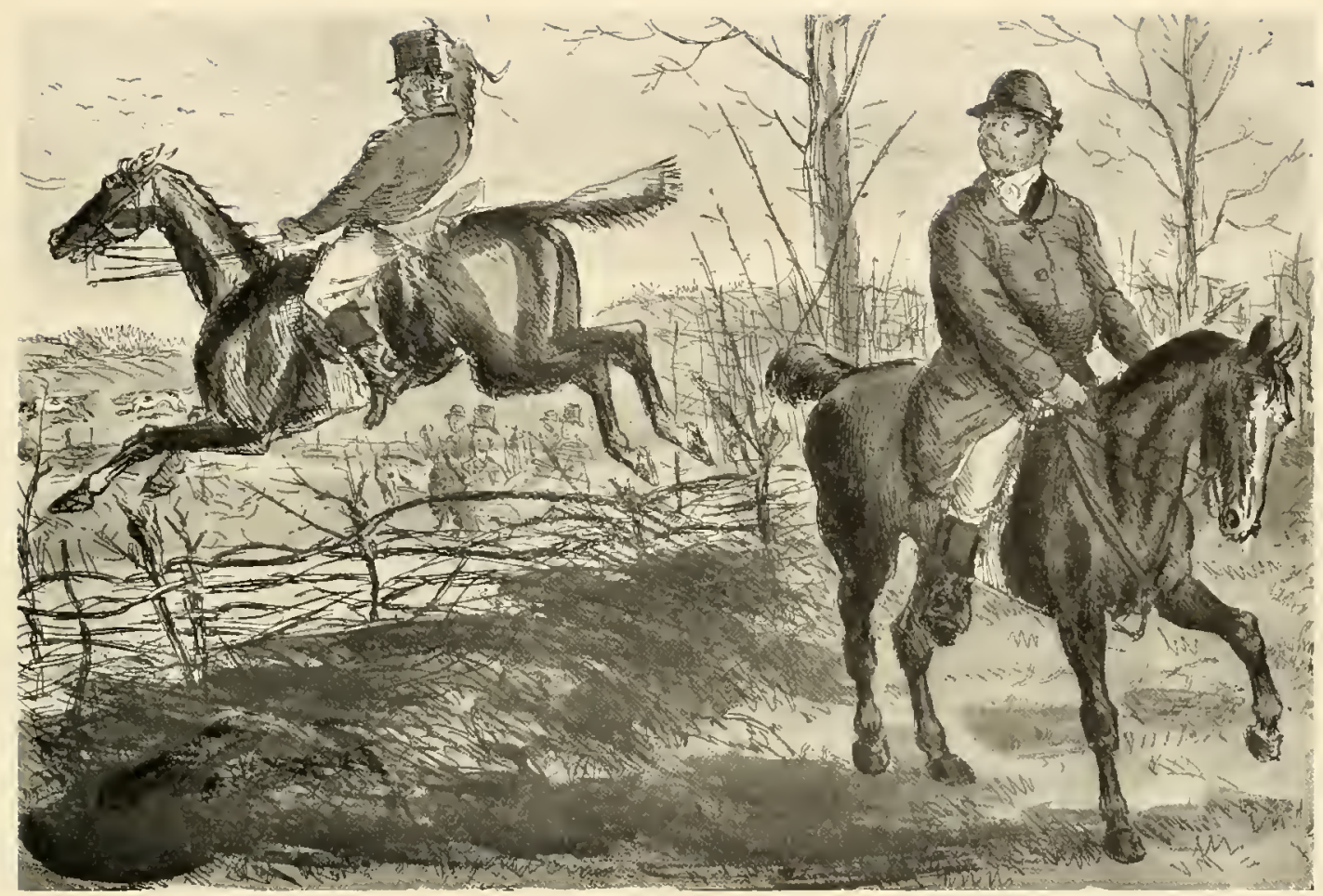

Romford disturbs the dignity of his Huntsman.-From "Mr. Facey Romford's Hounds." 


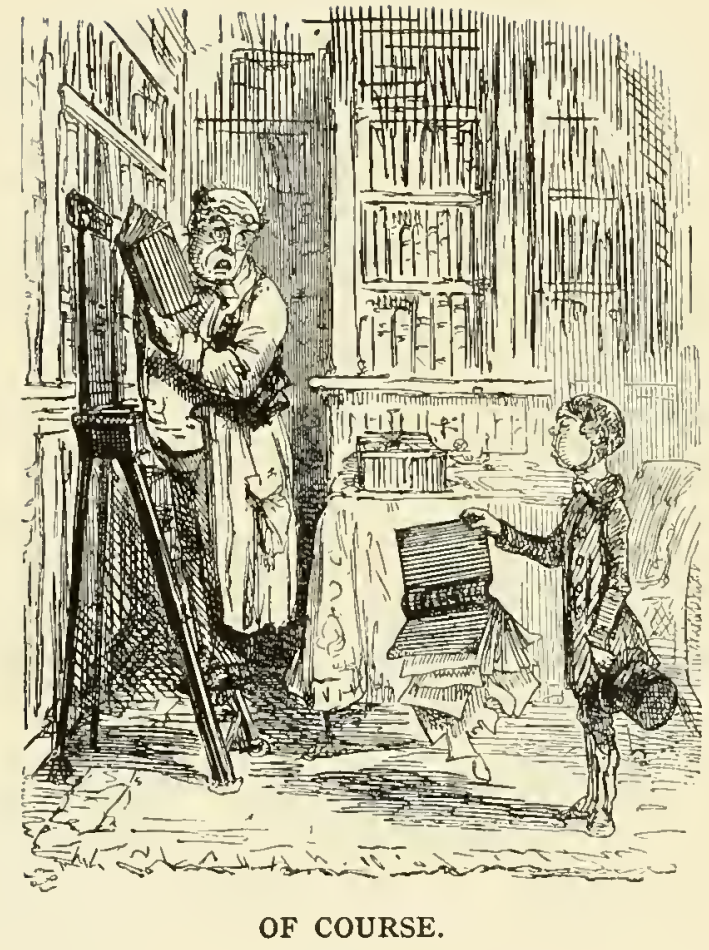

"If you please, Sir, Master's sent back the first volume, and he says, will you be so good as to let him 'ave the second?"

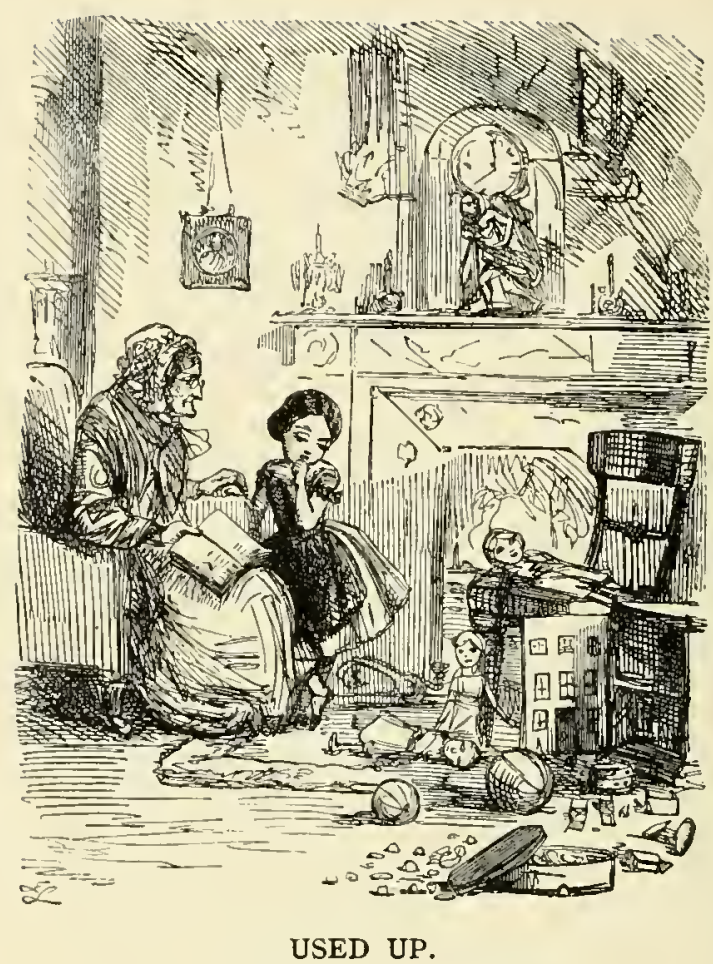

Grandmamma. "Why, what's the matter with my pet?"

Clild. "Why, Grandma, after giving the subject every consideration, I have come to the conclusion that - the world is hollow, and my doll is stuffed with sawdust, so-I should-like-if you please, to be a nun!" 


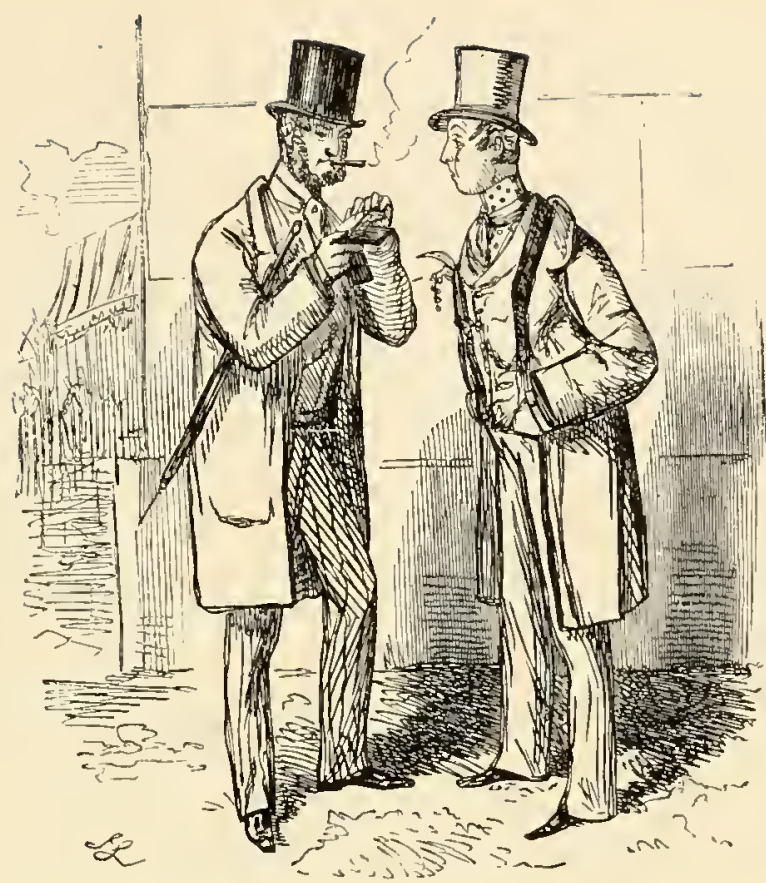

MR. VERDANT'S FIRST ATTEMPT AT BOOKMAKING.

Verdant's Friend. "Well-as near as I can make it out-you must lose $f_{1} 5^{\circ}$, and may lose $£_{300 . "}$

(Verdant subsides into his Book.) 


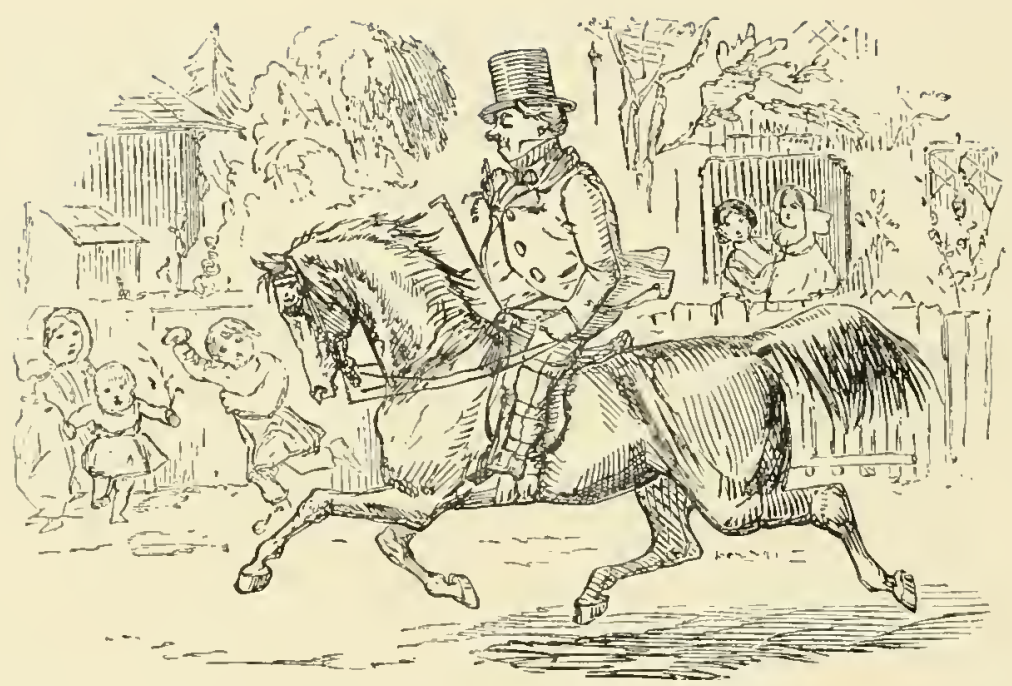

Mr. Br-ggs (He suppress the Gentleman's name for obvious rasons) thinks he will go to Hampton races. 


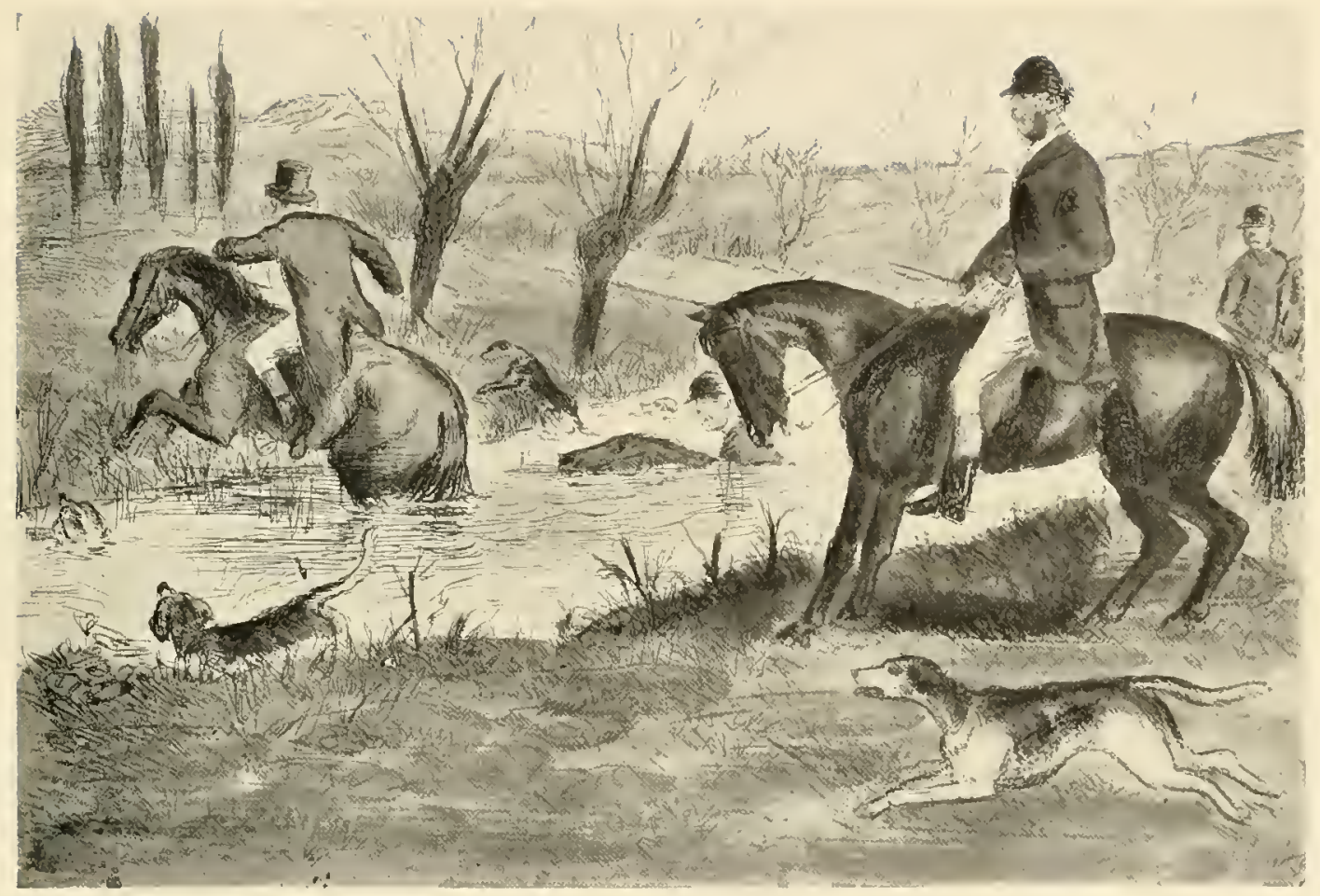

Captain Spurrier "cut down " by Romford.-From "Mr. Facey Romford's Hounds." 


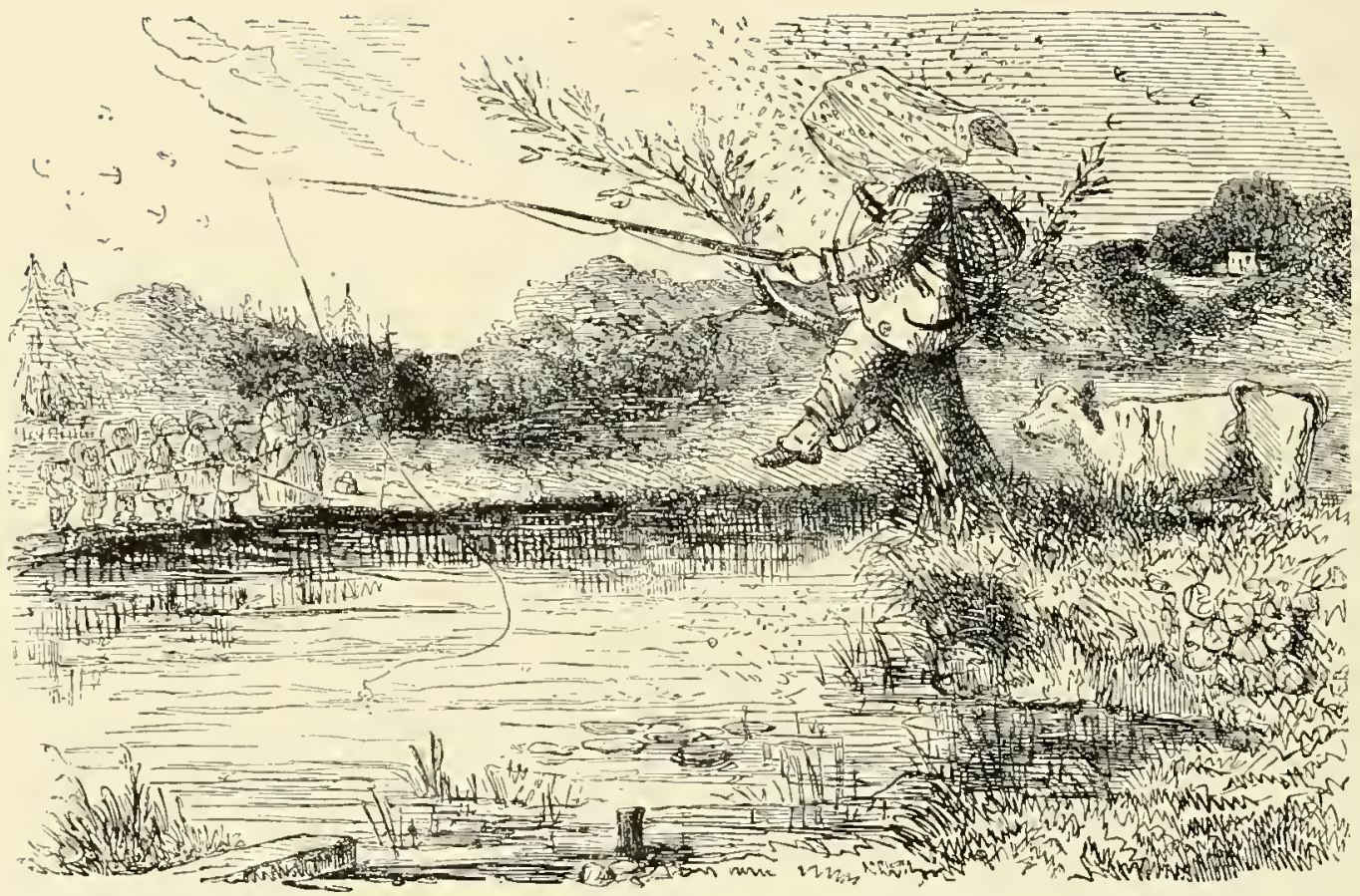

Disciple of Old Isaac. "This wouldn't be a bad place if the fish would only bite, and if it wasn't for this confounded wasps' nest." 


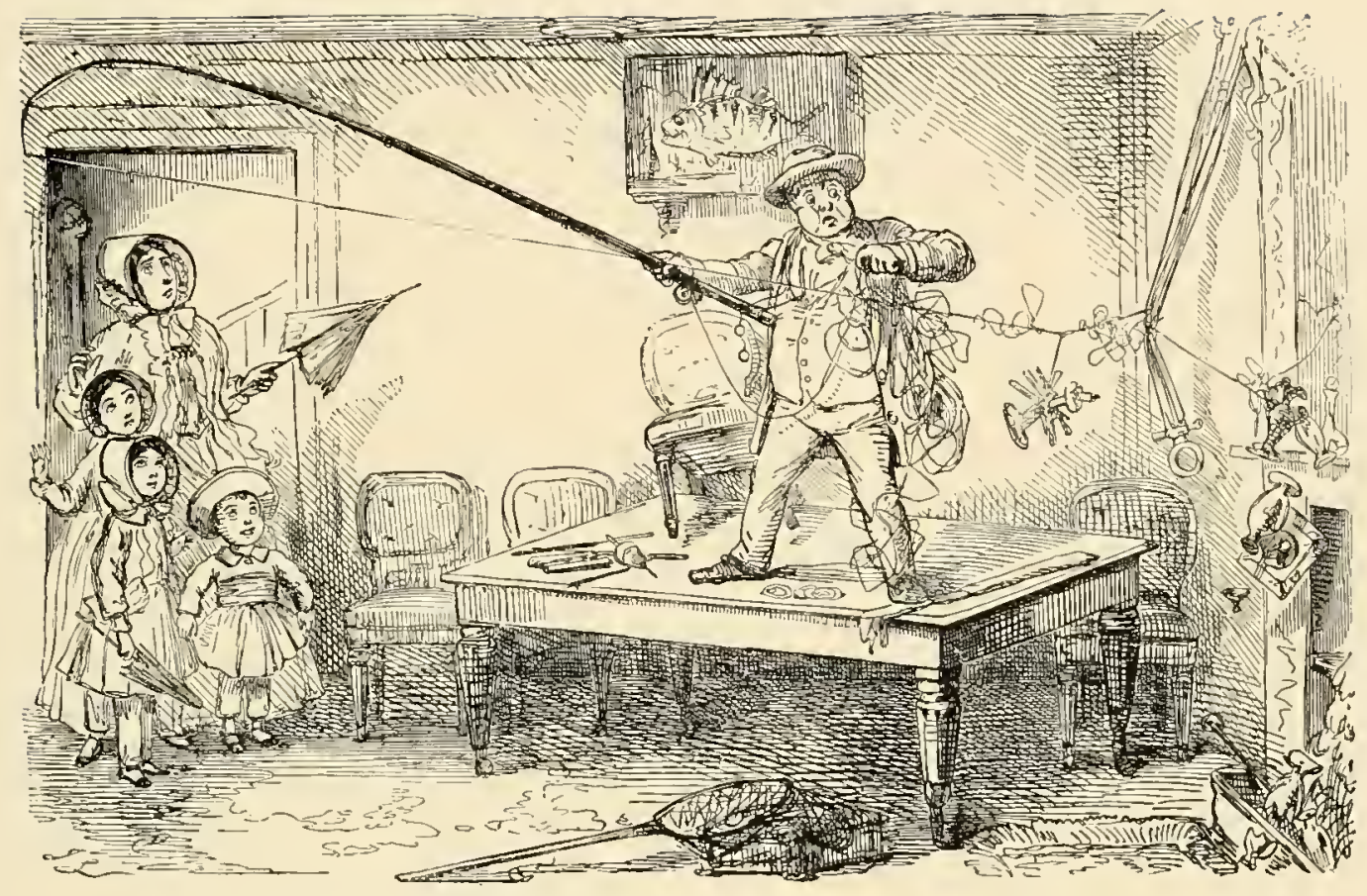

OUR FRIEND BRIGGS CONTEMPLATES A DAY'S FISHING. 


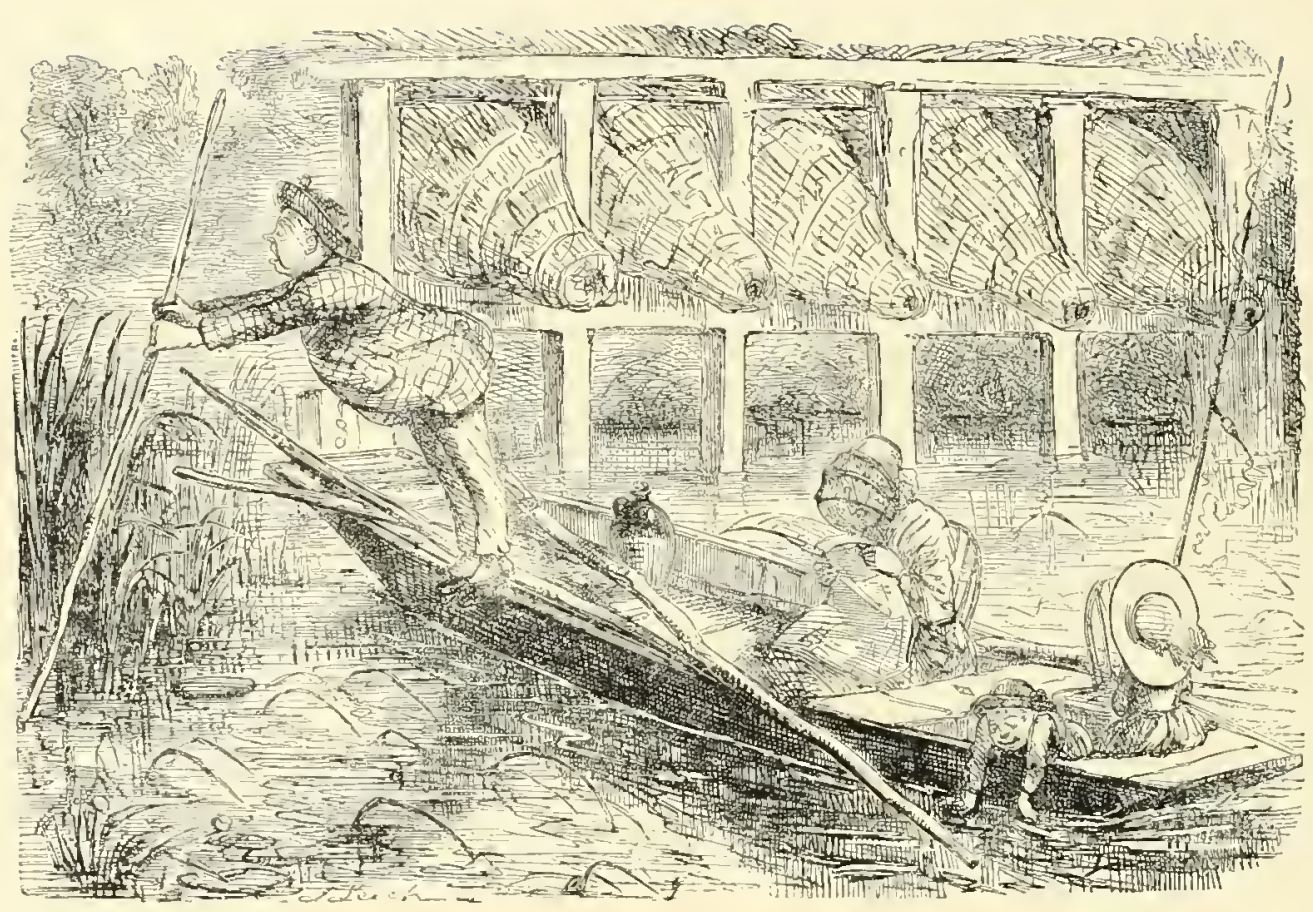

MR. BRIGGS STARTS ON HIS FISHING EXCURSION. 


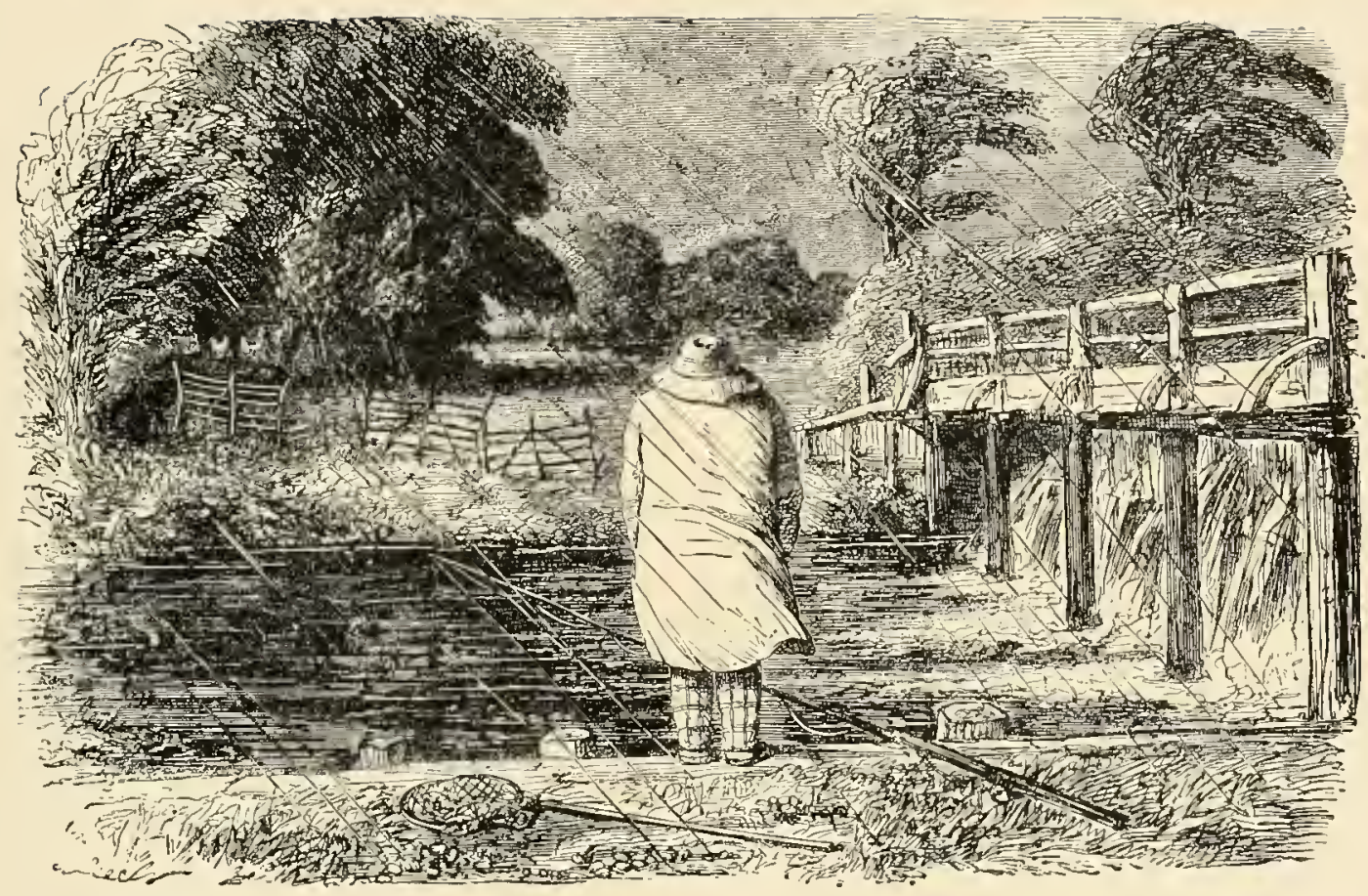

Mr. Briggs tries (for many hours) a likely place for a perch. But upon this occasion the wind is not in a favourable quarter. 


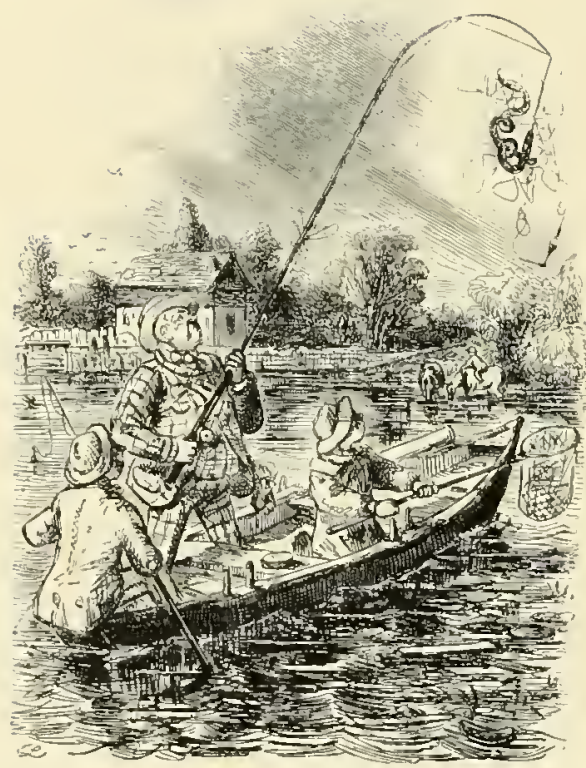

MR. BRIGGS HAS ANOTHER DAY'S FISHING.

$\mathrm{He}$ is so fortunate as to catch a large eel. 


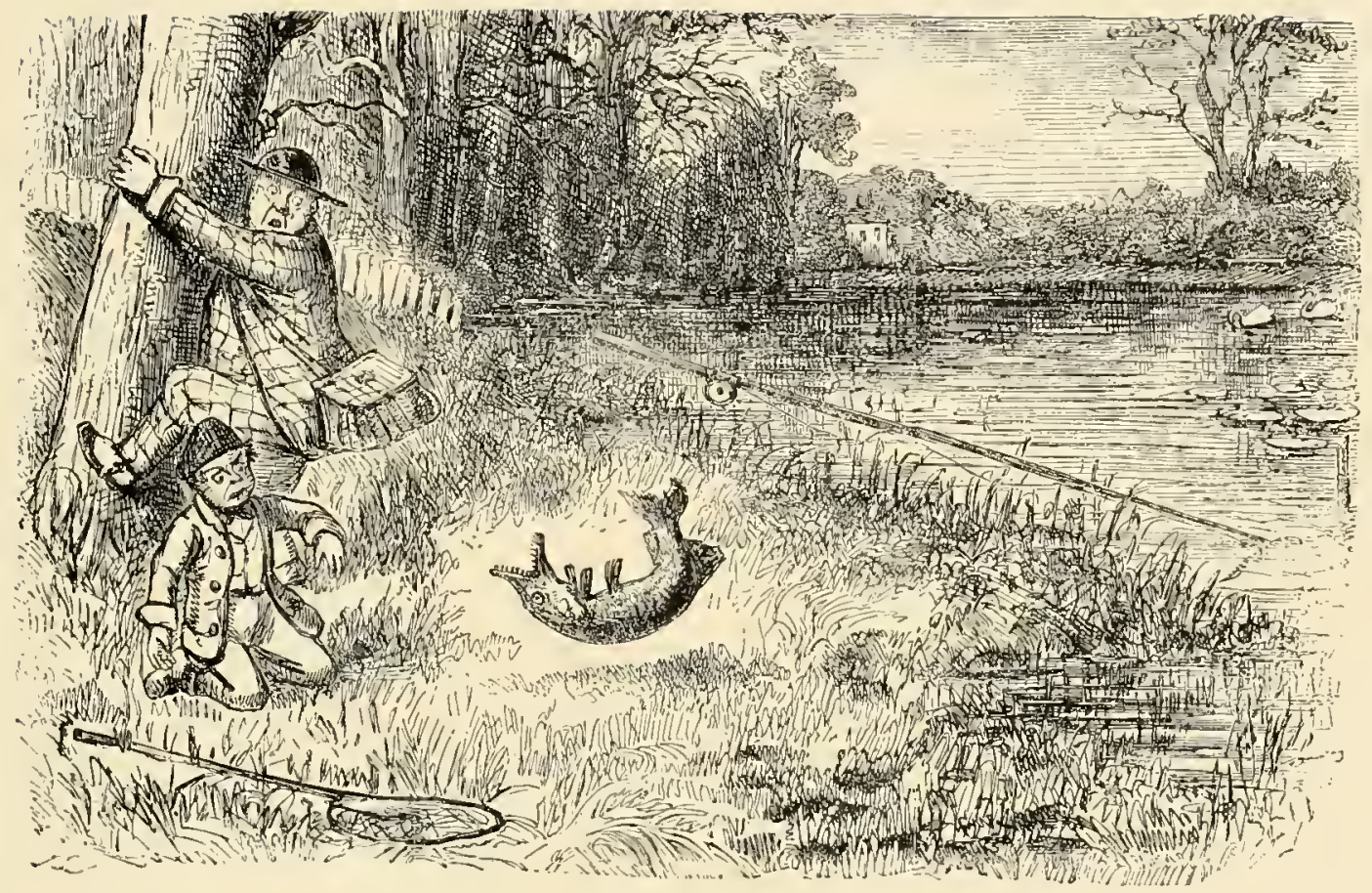

TRIUMPHANT SUCCESS OF MR. BRIGGS.

Somehow or other (assisted by his little boy Walter), he catches a jack which, to use Mr. B's own words, flies at him, and barks like a dog. 


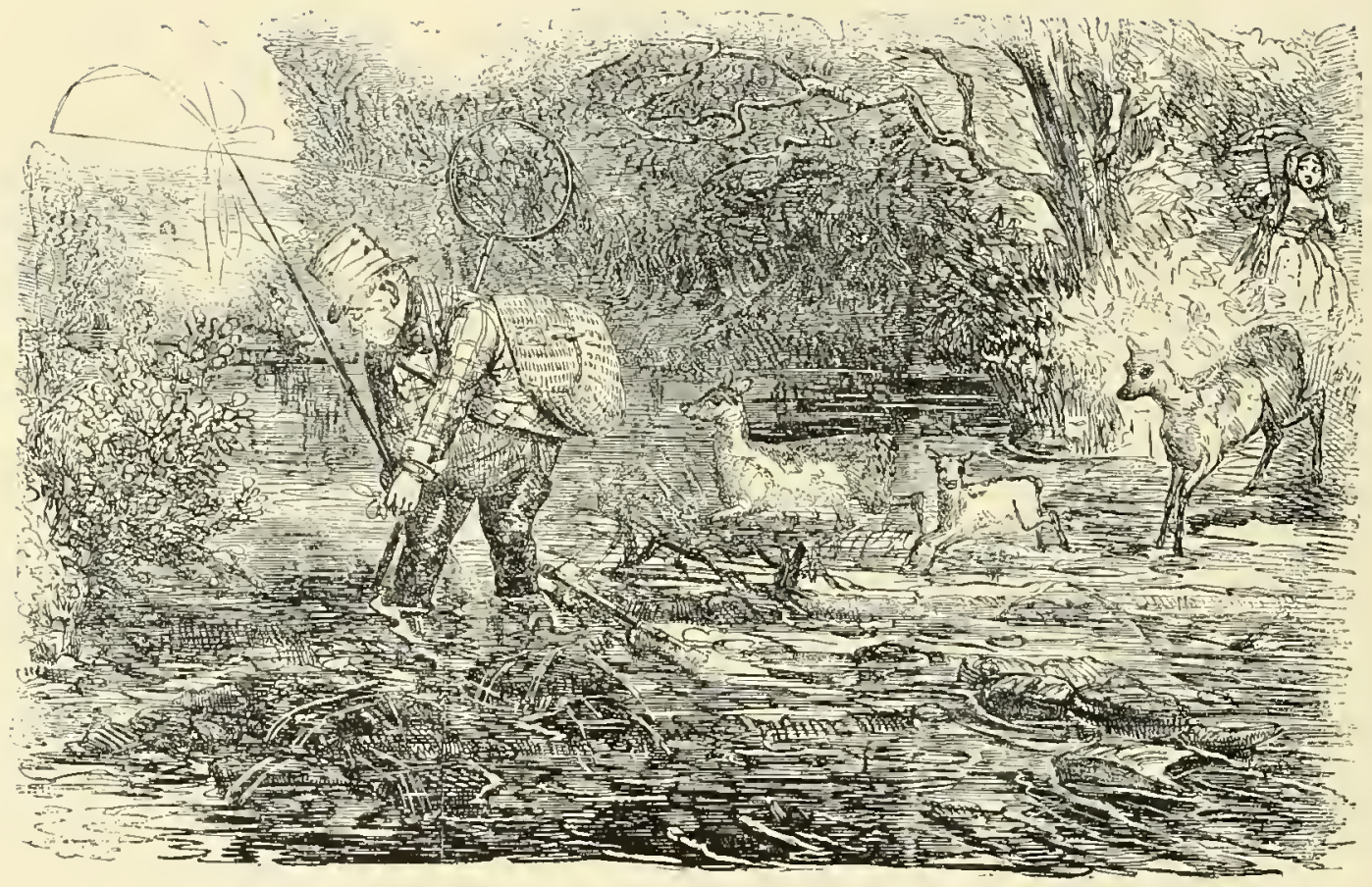

Mr. B. goes out. His chief difficulty is, that every time he throws his line-the hooks (of which there are five) will stick behind in his jacket and tr-ws-rs. 


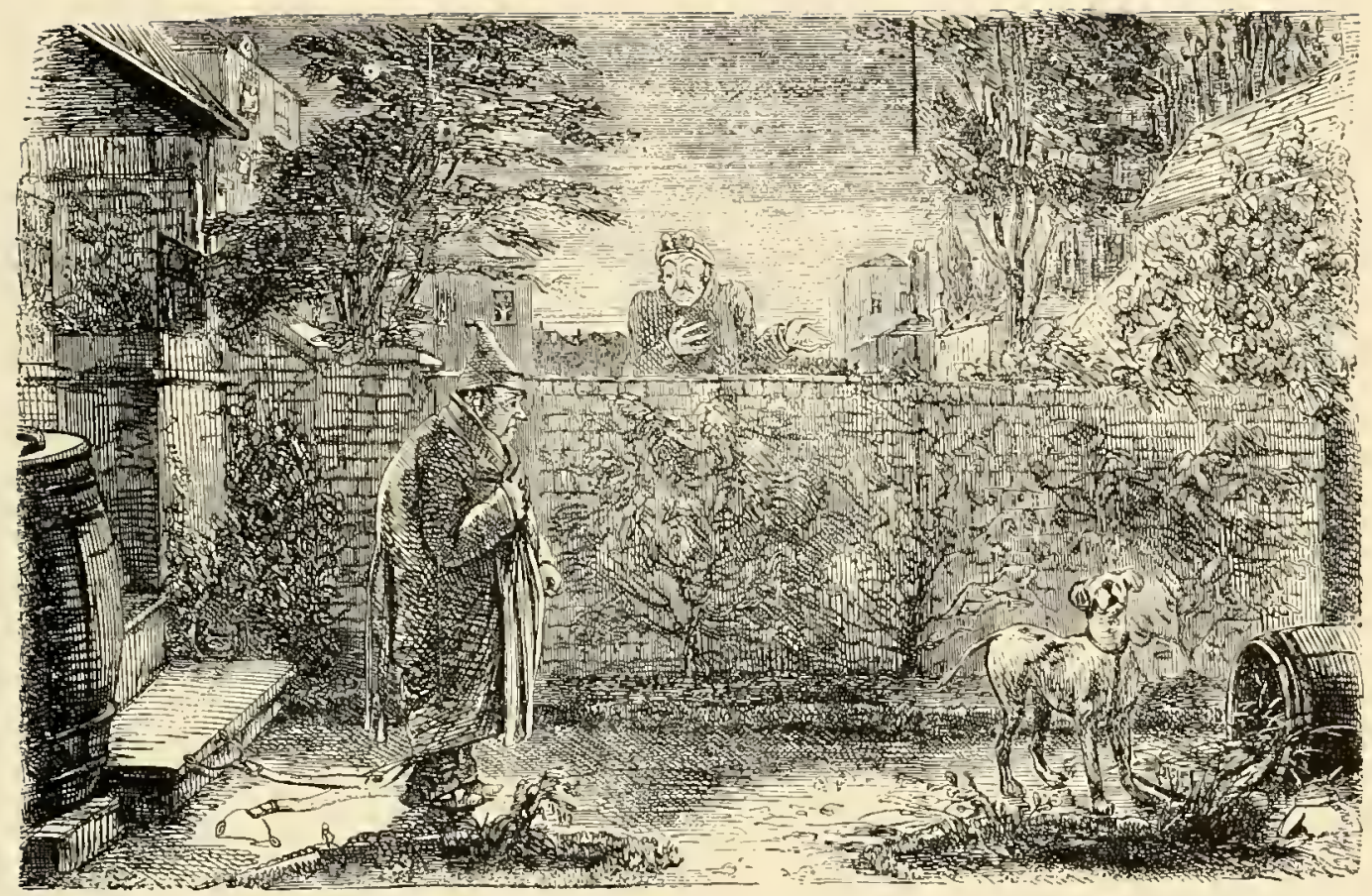

Mr. Briggs thinks of running down the day after to-morrow to his friend Haycock for a day's shooting, and has borrowed a dog to go with him. For the ninth time during the night he has been disturbed by the howling of the animal. 


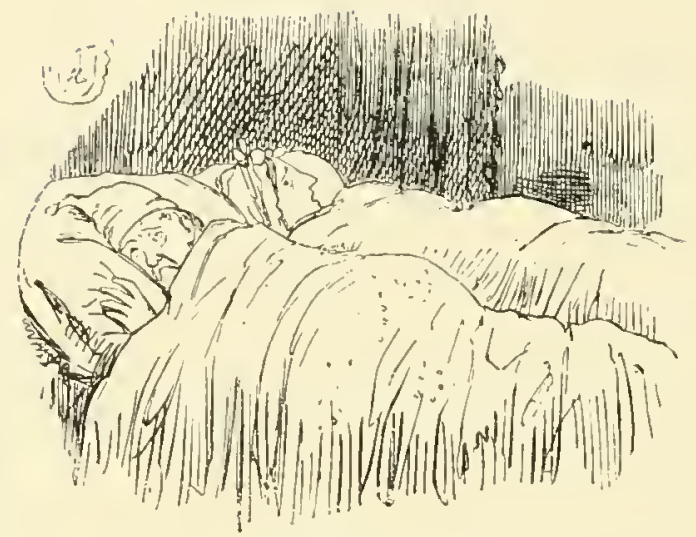

Mr. Briggs no sooner returns to his bed, than Mrs. Briggs says, "My dear! there's that nasty, tiresome dog again!!" 


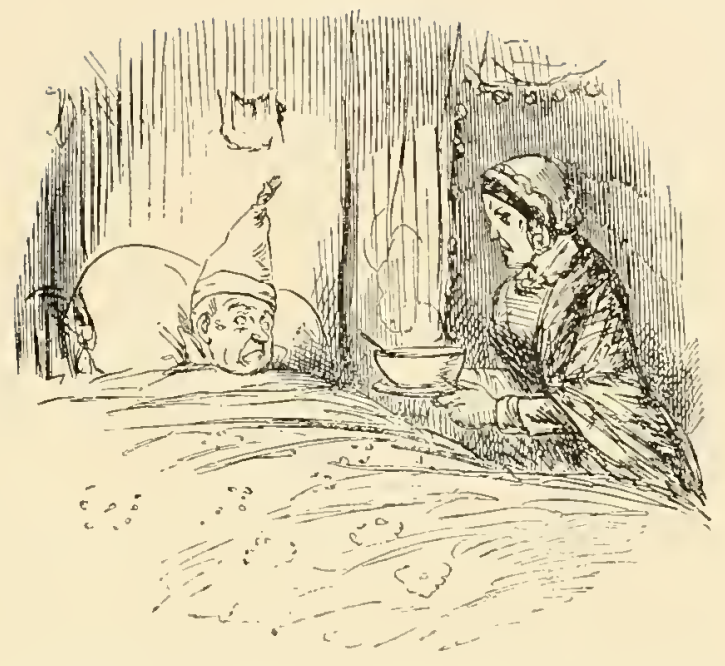

Mr. B. won't have a man with him, as he thinks he can manage a punt by himself; and the consequence is, he is obliged to go to bed while his things are dried, having upset himself, as a matter of course. 


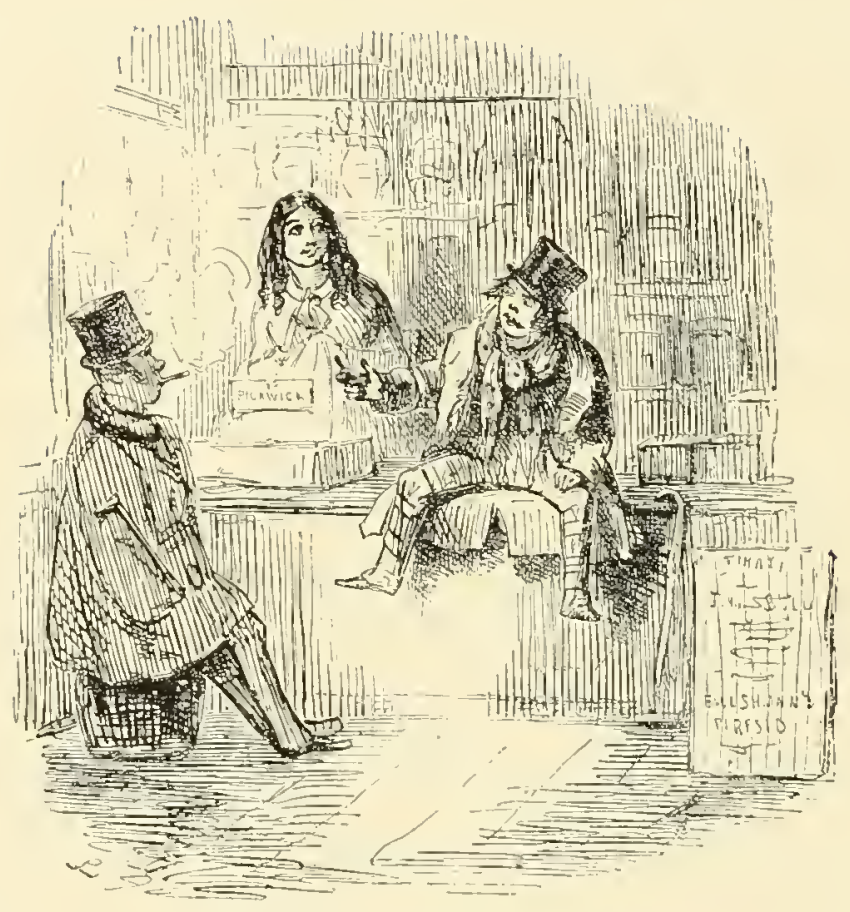

OUR NATIONAL DEFENCES.

Small Briton. "The French invade us, indeed! and what should we be about all the time? - why, we should rise like one man!" 


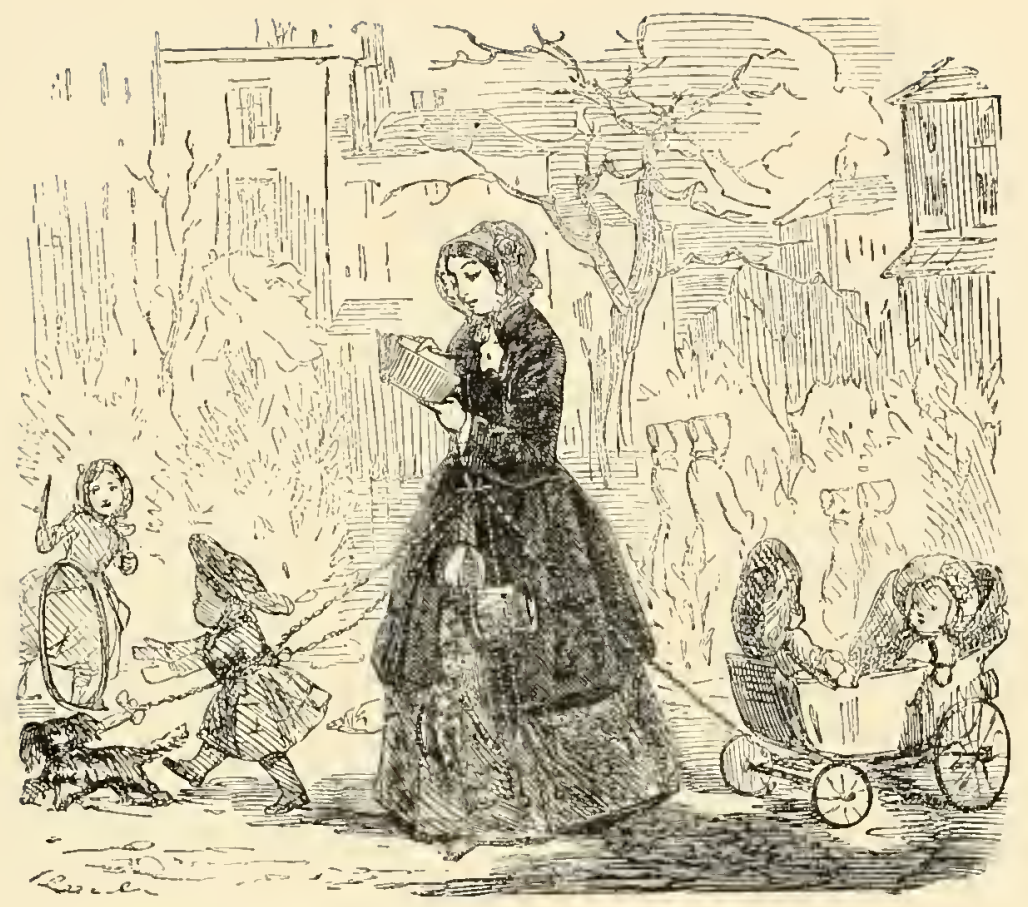

HOW TO MAKE A CHATELAINE A REAL BLESSING TO MOTHERS. 


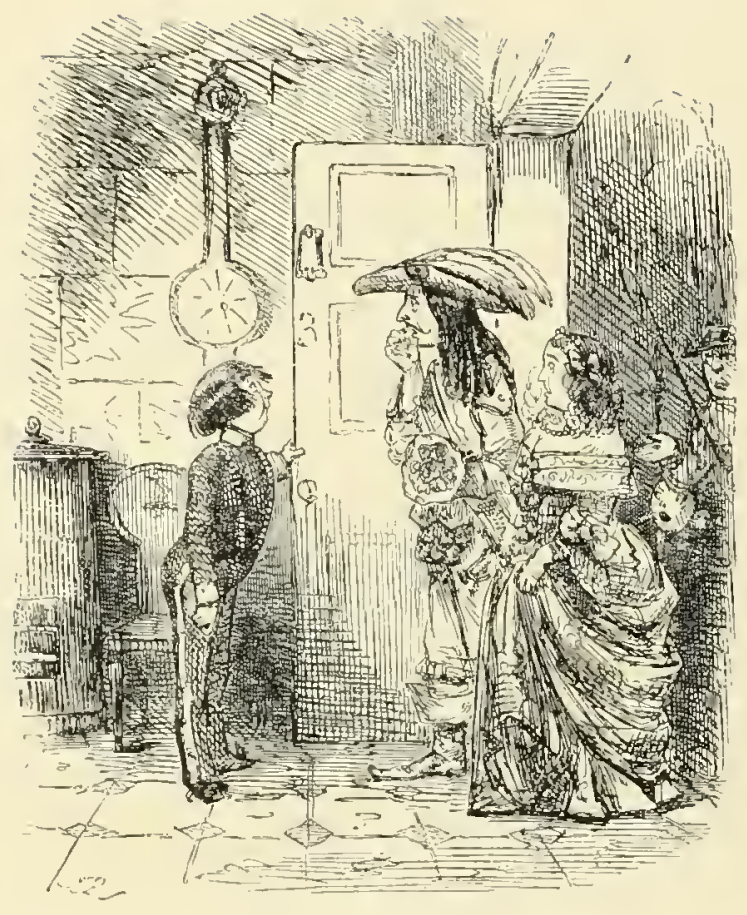

A LATE ARRIVAL.

Page. “Fancy ball, Sir! No, Sir! Missus's fancy ball, Sir, were last Toosday, Sir." 


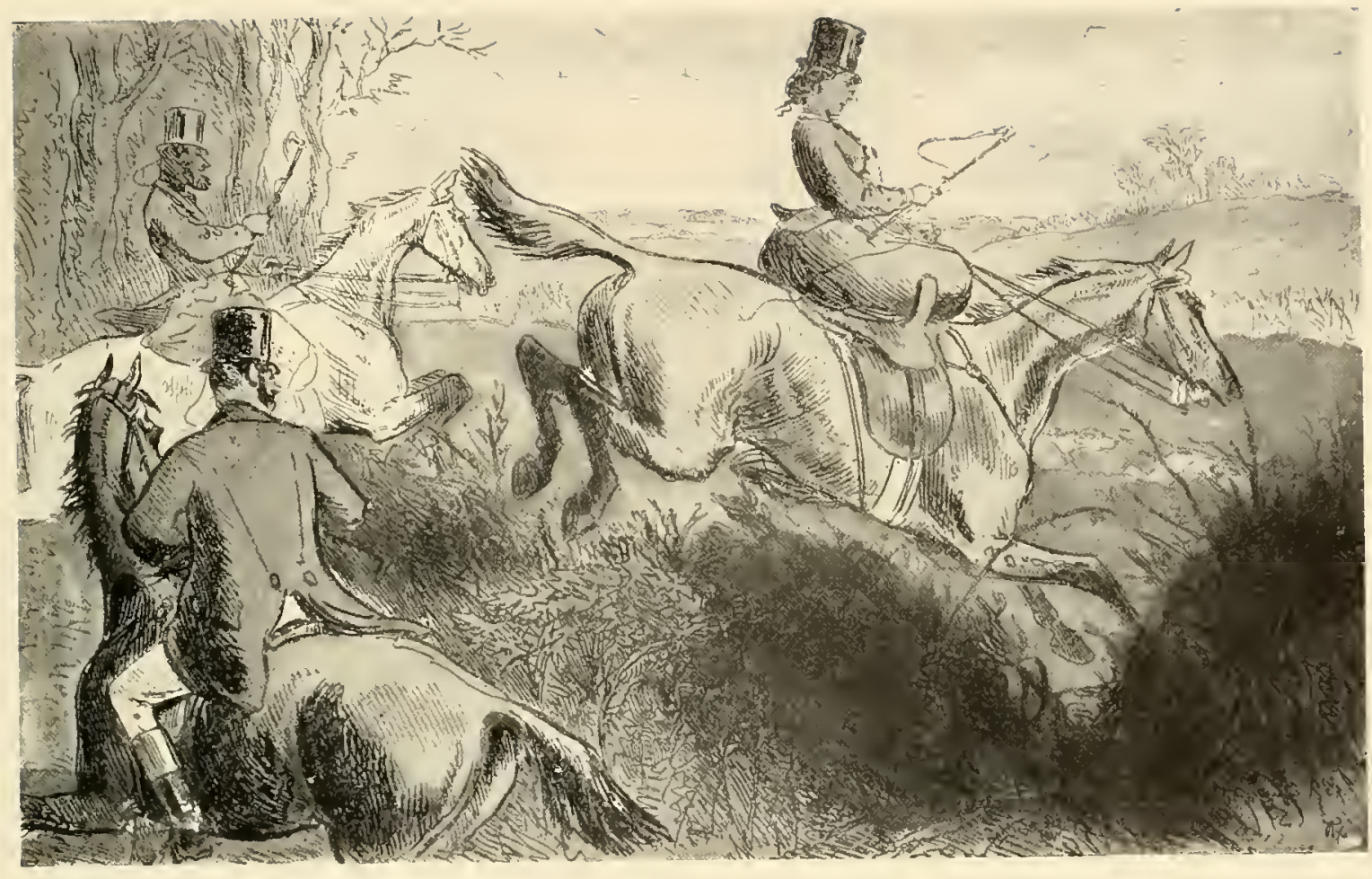

"What matter did it make to him how she rode,-confound this ugly place."-From " Mr. Facey" Romford's Hounds." 


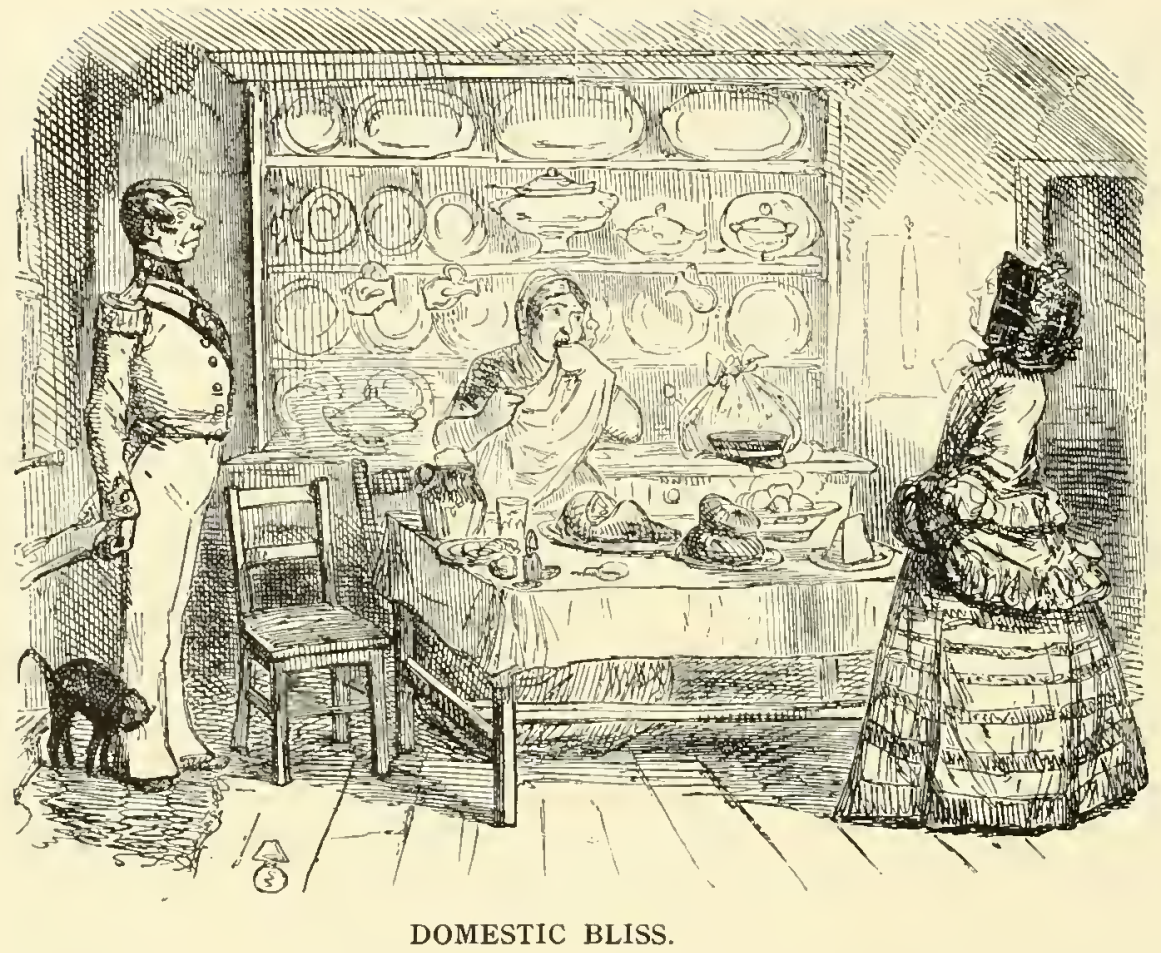

Mistress. "Well, I'm sure; and pray who is that?"

Cook. "Oh, if you please ' $m$, it's only my cousin who has called just to show me how to boil a potato." 


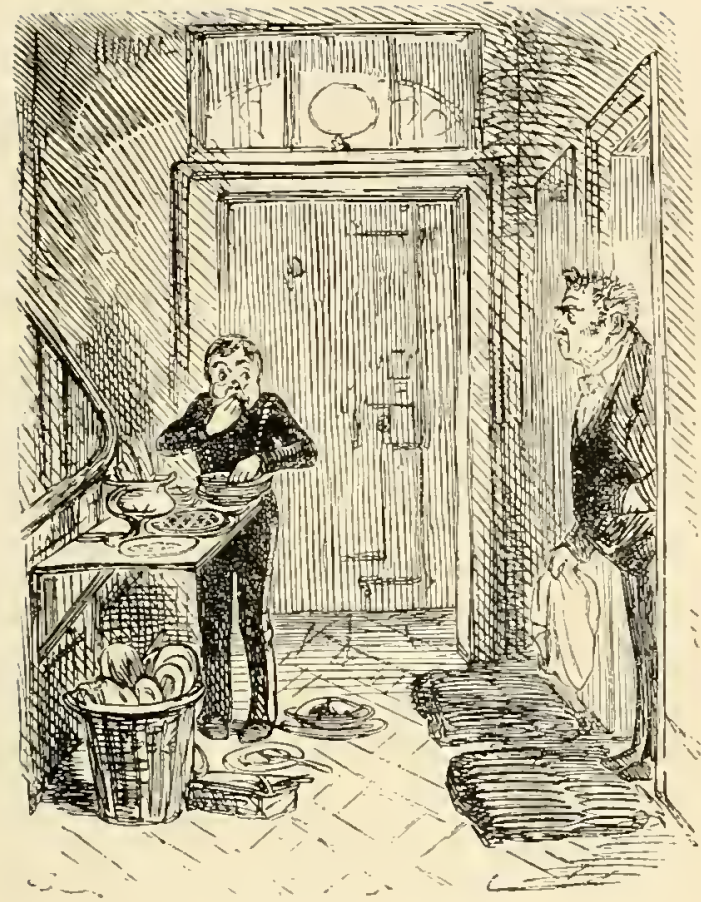

A DUMB WAITER.

Old Gentlonan. "What the deuce is the reason, Sir, you don't answer when you are called?" (The reason is obvious. The poor child has his mouth full of green peas and jam wart.)

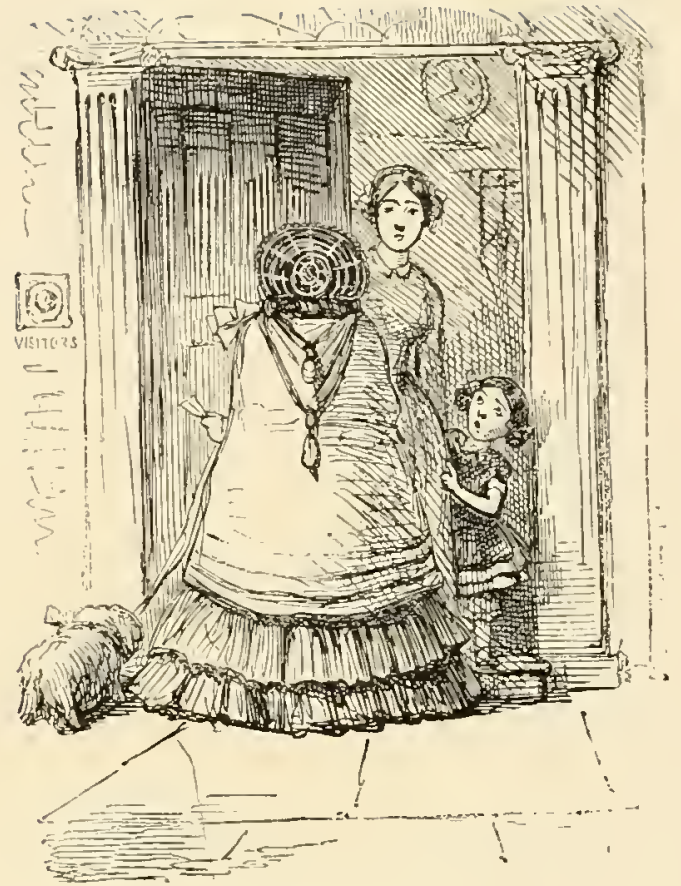

MURDER WILL OUT.

Mrs. Smith. "Is Mrs. Brown in?"

lanc. "No, mem, she's not at home."

Little Girl. "Oh! what a horrid story, Jane! Ma's in the kitchen, helping cook!" 


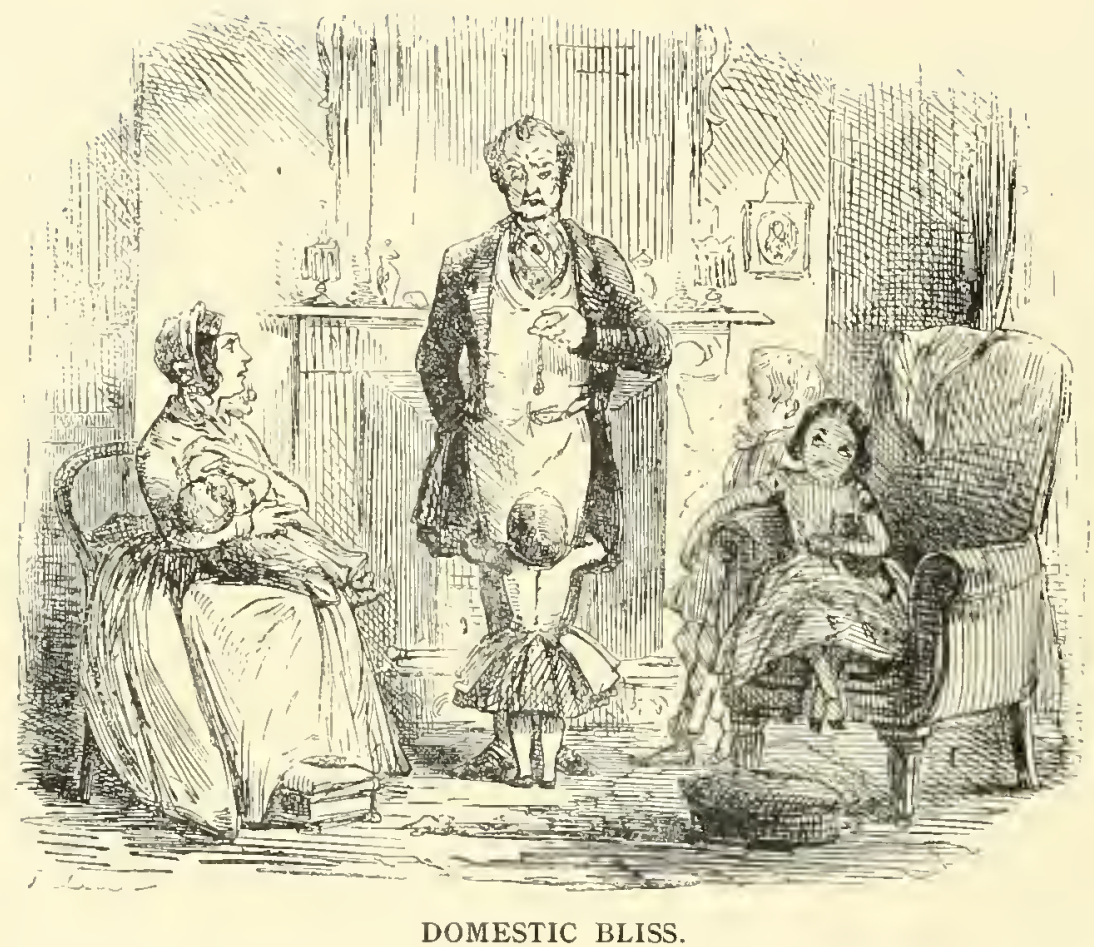

Patcrfamitias. "I cannot conceive, my love, what is the matter with my watch; I think it must want cleaning."

Pet C'ild. "Oh, no! Papa dear! I don't think it wants cleaning, because baby and I had it washing in the basin for ever so long this morning!" 


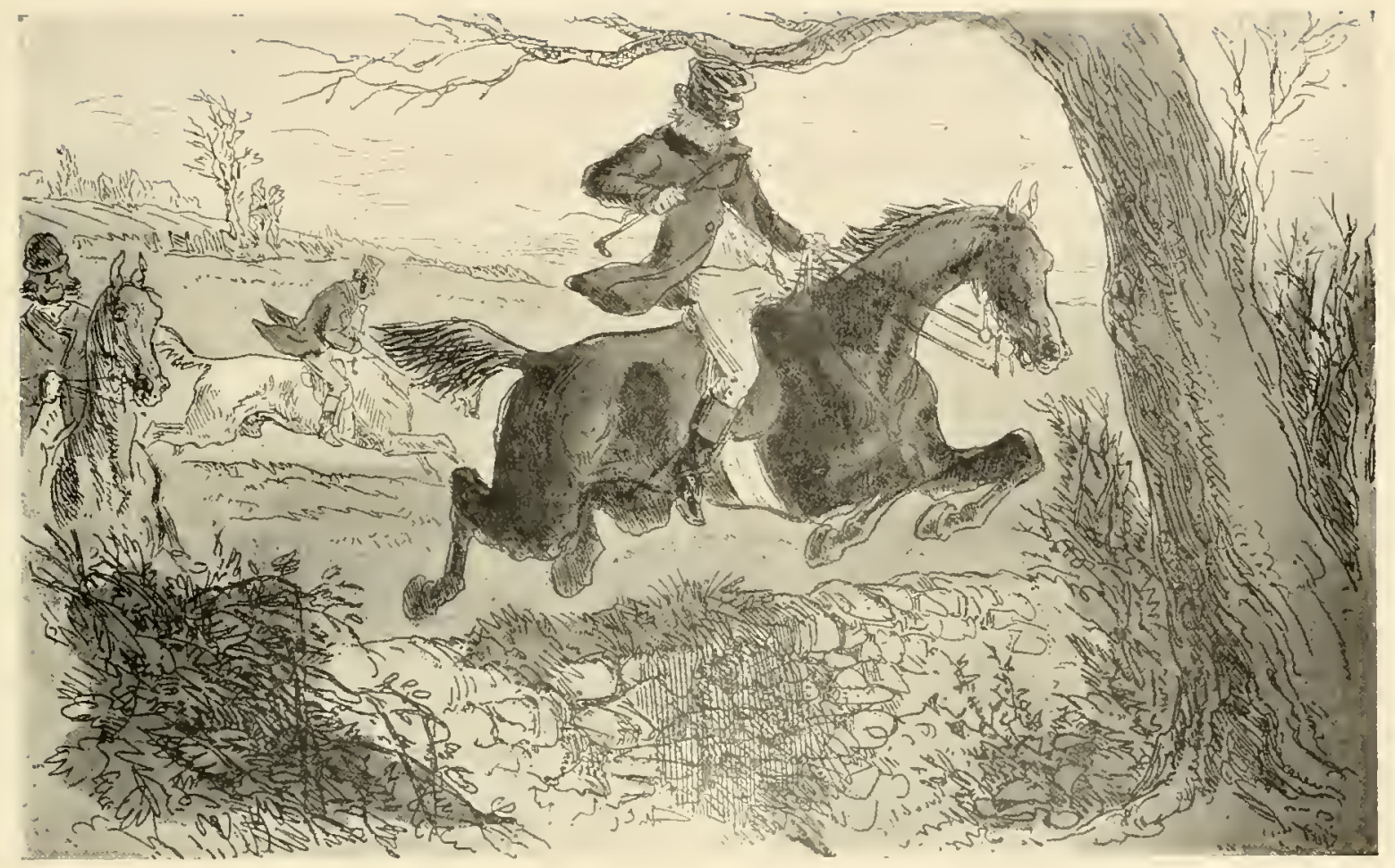

"Rot the beggar," exclaims Romford.-From "Mr. Facey Romford's Hounds." 


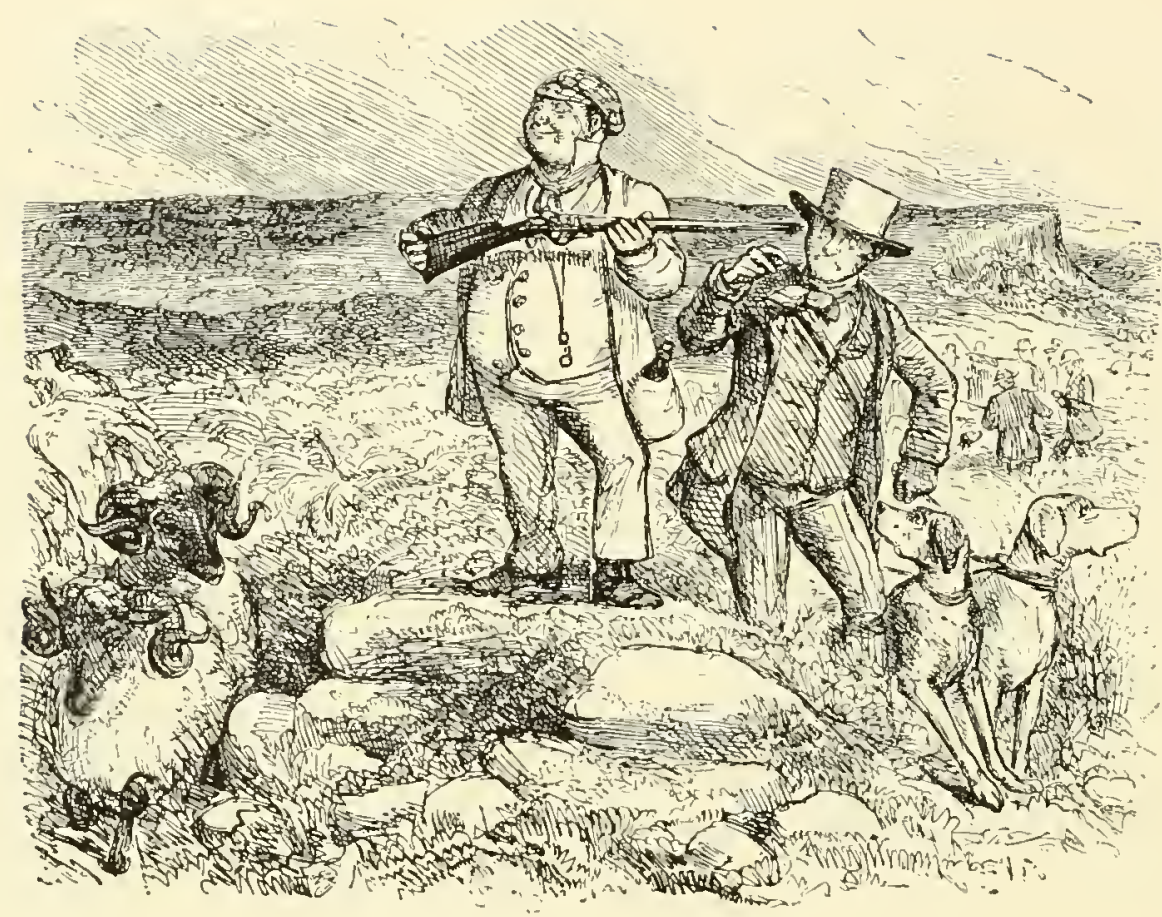

MR. BRIGGS GROUSE SHOOTING.

9 A.M., his arrival on the moor. Mr. Briggs says that the fine bracing air makes him so vigorous that he shall never be beat. He also facetiously remarks that he is on " his native heath," and that his " name is Macgregor!"

The result of the Day's Sport will be communicated by Electric Telegraph. 


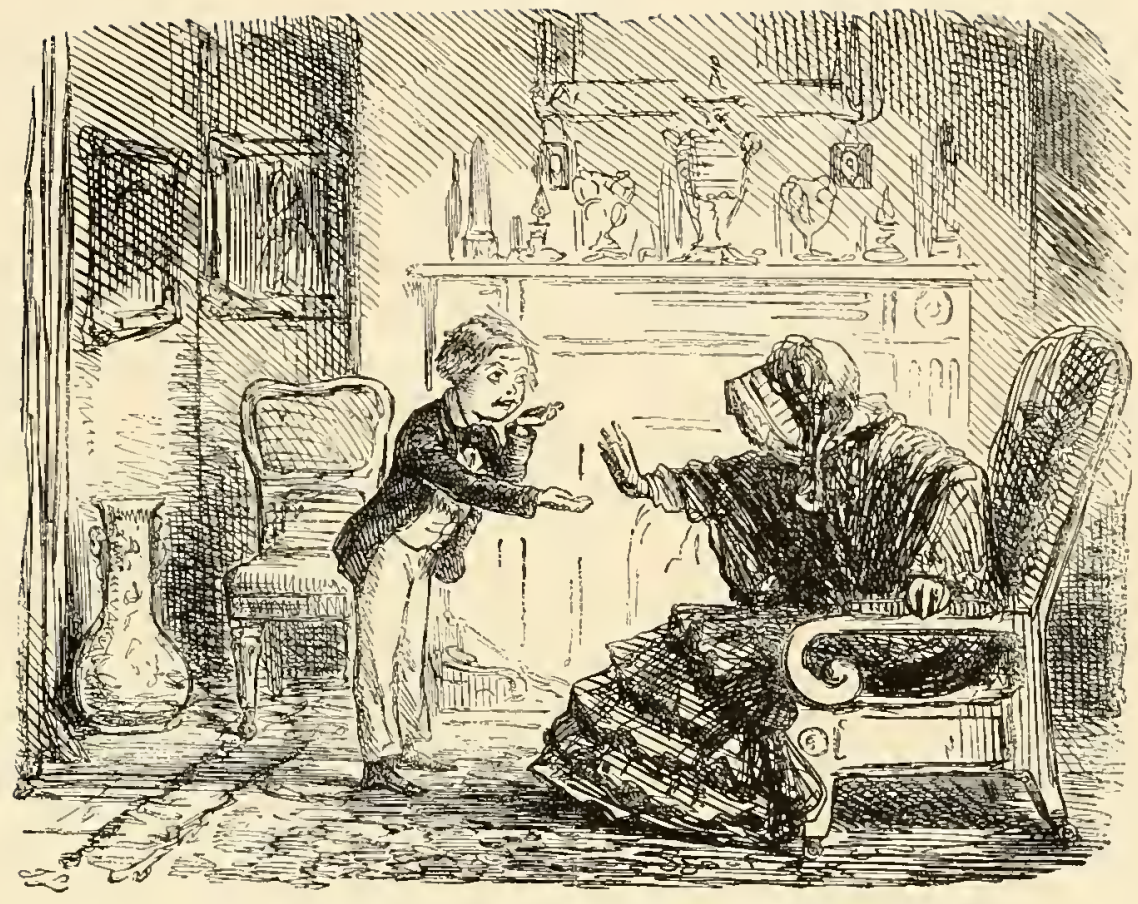

GRANDMAMMA IS SUPPOSED TO HAVE GIVEN MASTER TOM SOME PLUMS.

Master Tom. "Now, then, Granny, I've eaten the plums, and if you don't give me sixpence, I'll swallow the stones!" 


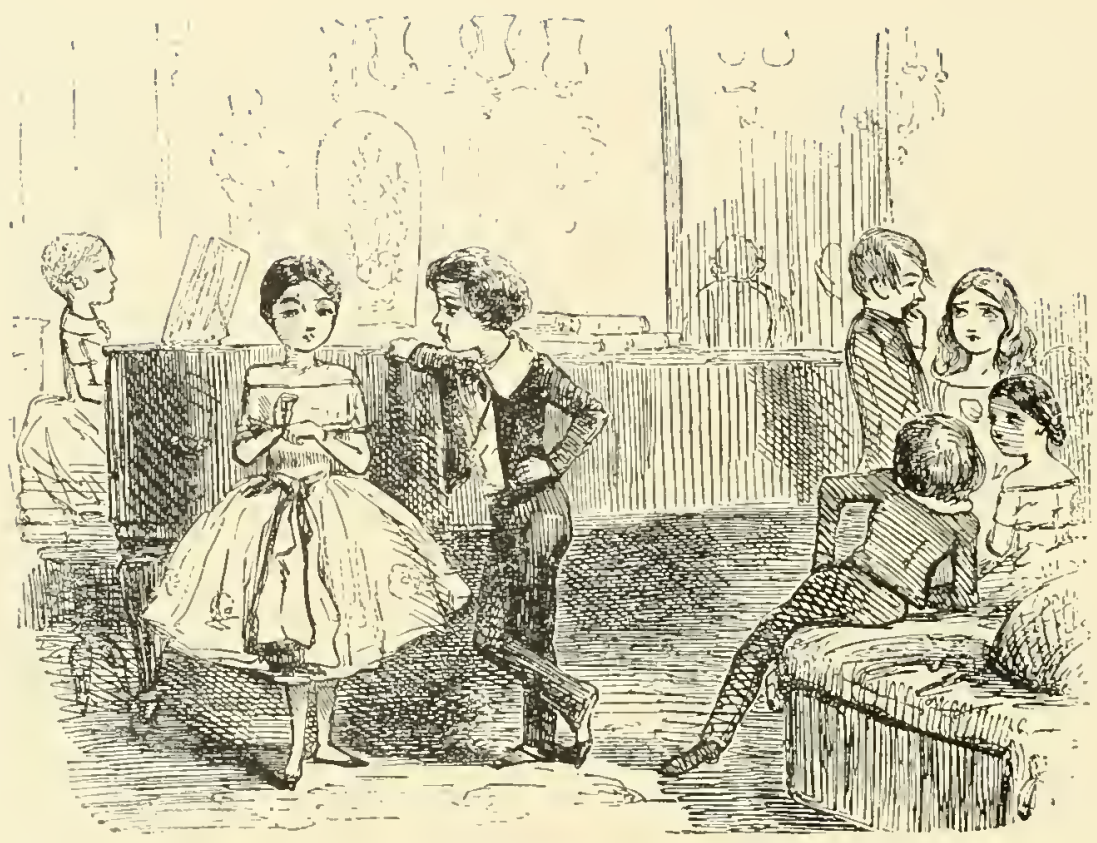

NOTHING LIKE PRUDENCE.

Maria (loq.). "My dear Charles, before we think of marrying, I must ask you what you have?"

Charles. "My dear Maria, I will tell you frankly that all I have in the world is a drum and a cricket bat; but papa has promised me a bow and arrows, and a pony, if I'm a good ioy." that!"

Maria. "Oh! my dear Charles, we could never live and keep house upon 


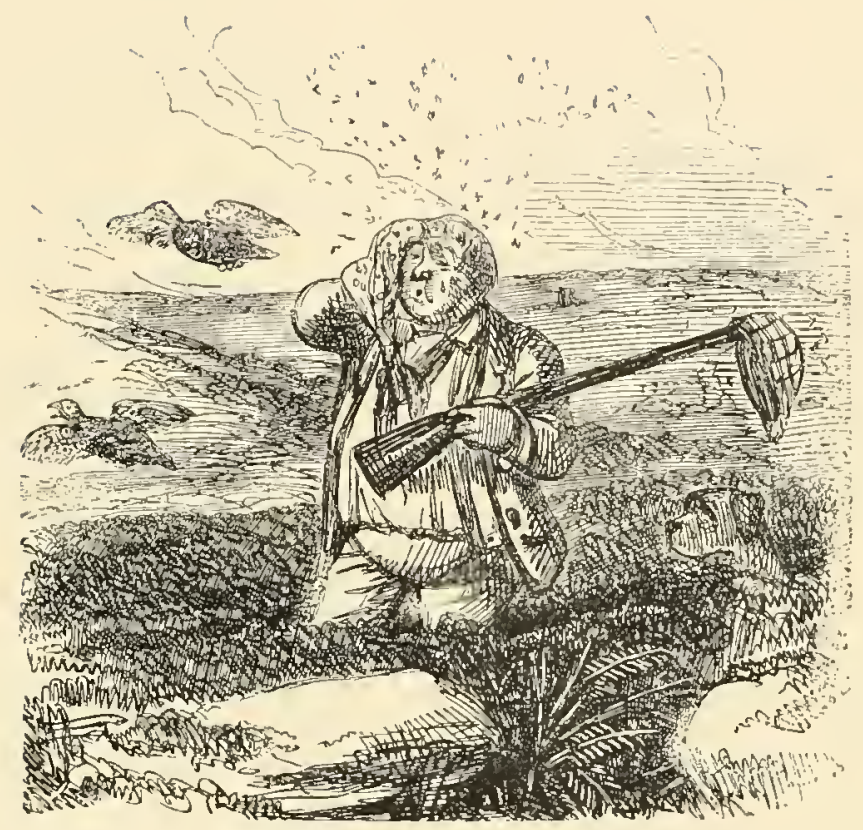

MR. BRIGGS GROUSE SHOOTING.

II A.M. Mr. Briggs begins to show symptoms of distress. He finds his " native heath" a very different thing to his

"native flagstones." 


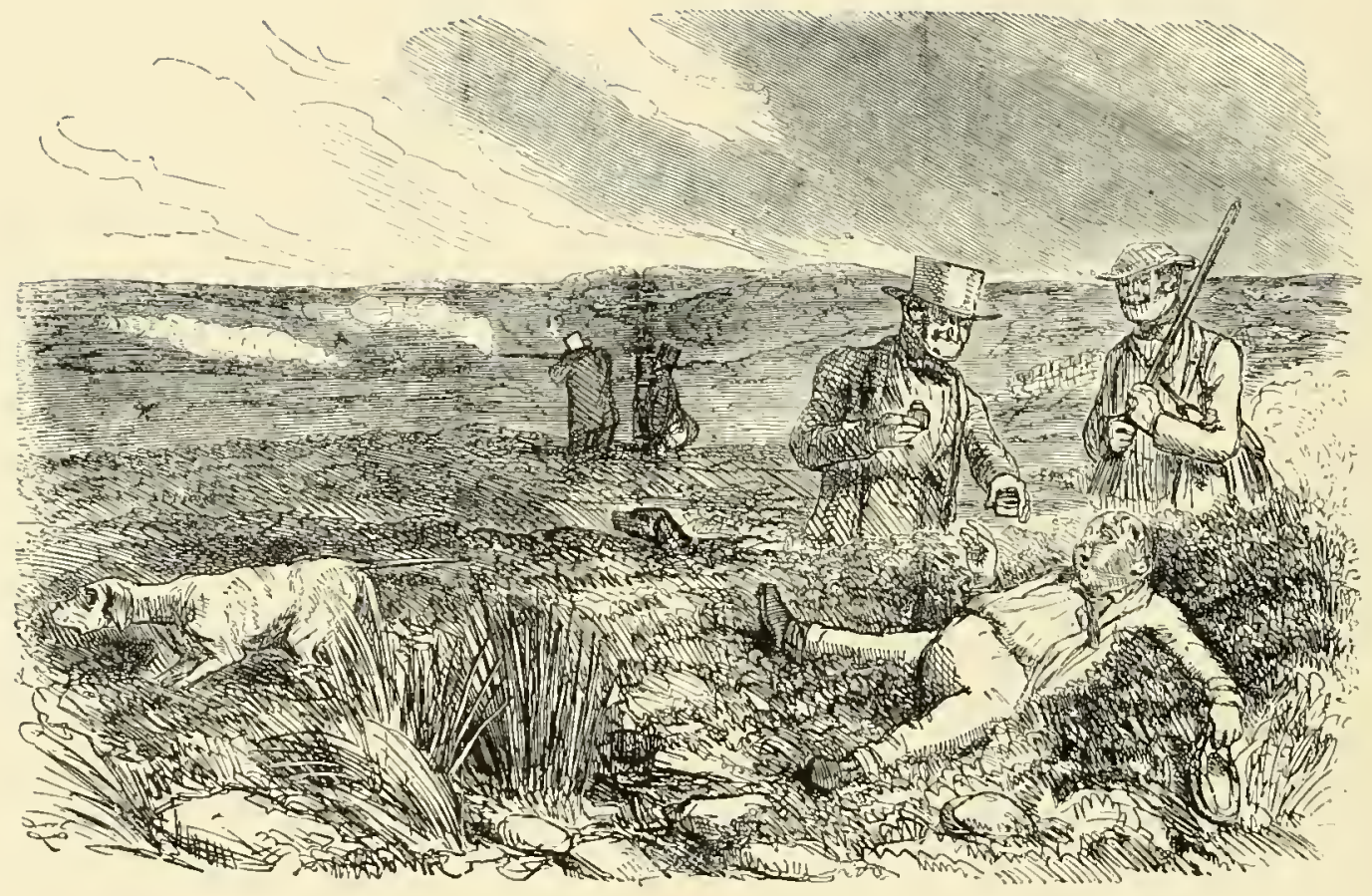

I2 M. Total prostration of Mr. Briggs. 


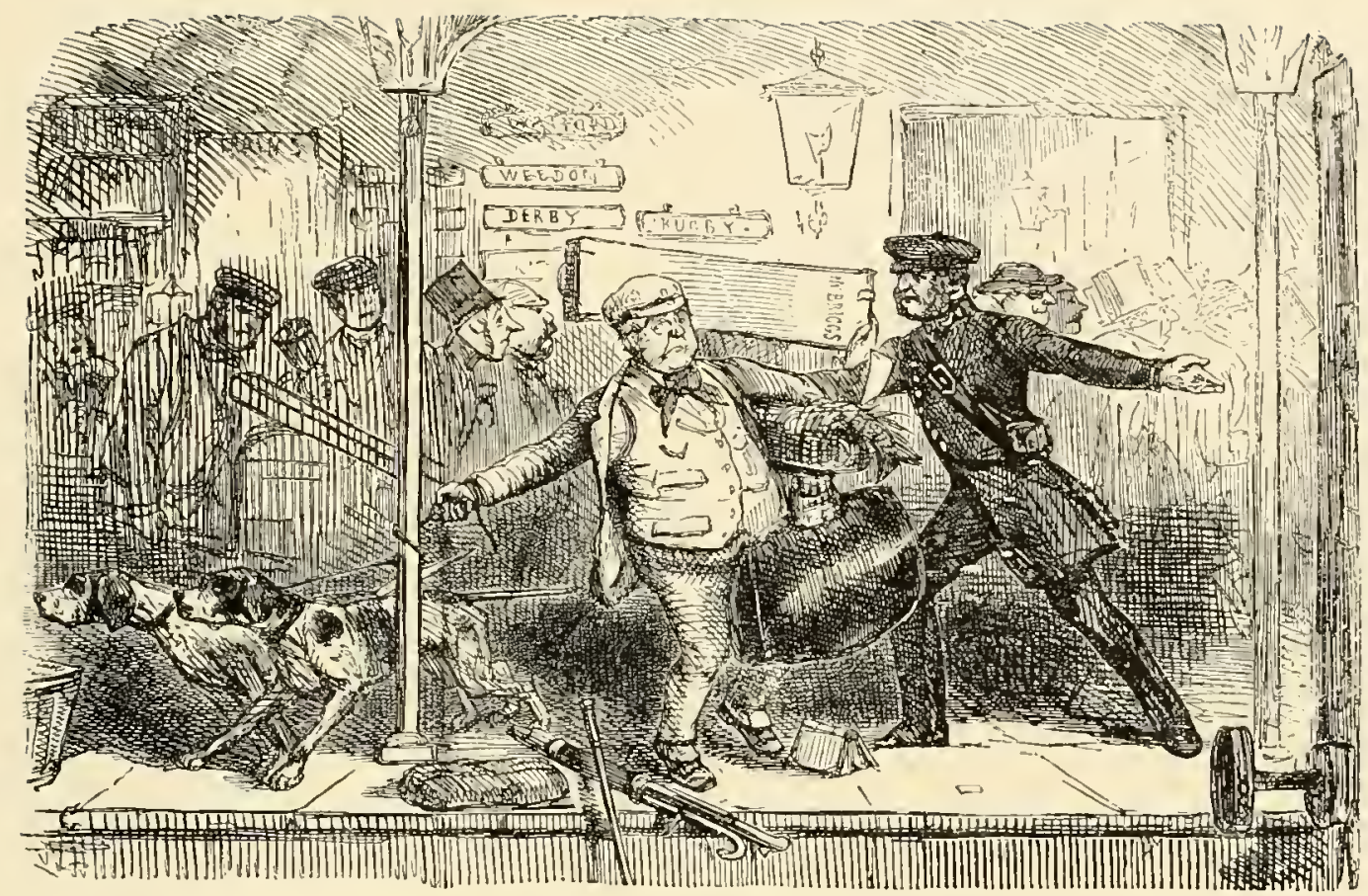

MR. BRIGGS IS OFF AGAIN SHOOTING. 


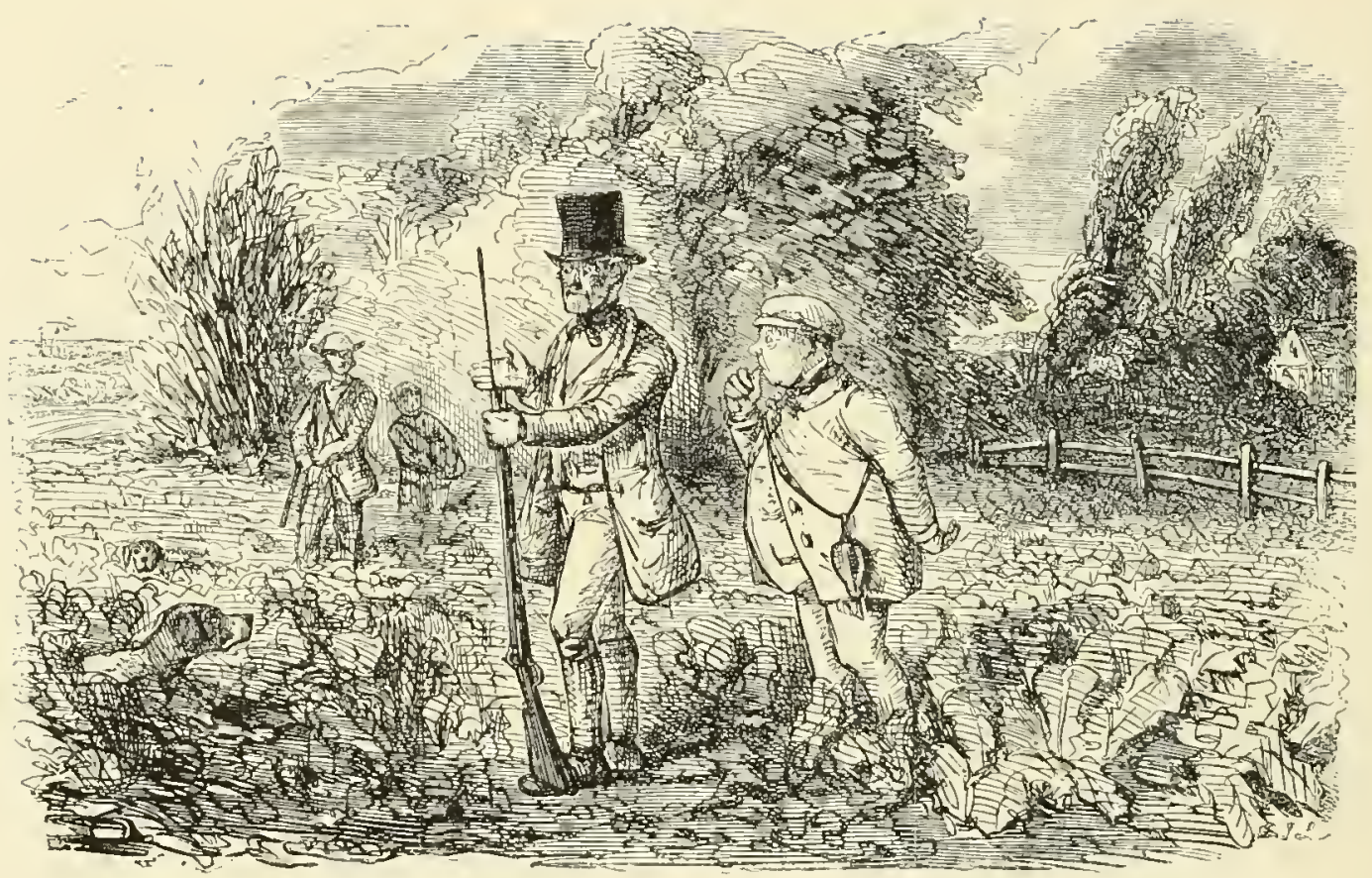

MR. BRIGGS ON THE FIRST.

Fortunately for Mr. Briggs (who will load his own gun because then he knows what he is about) the keeper discovers that he has put about three quarters of a pound of shot into his right-hand barrel. 


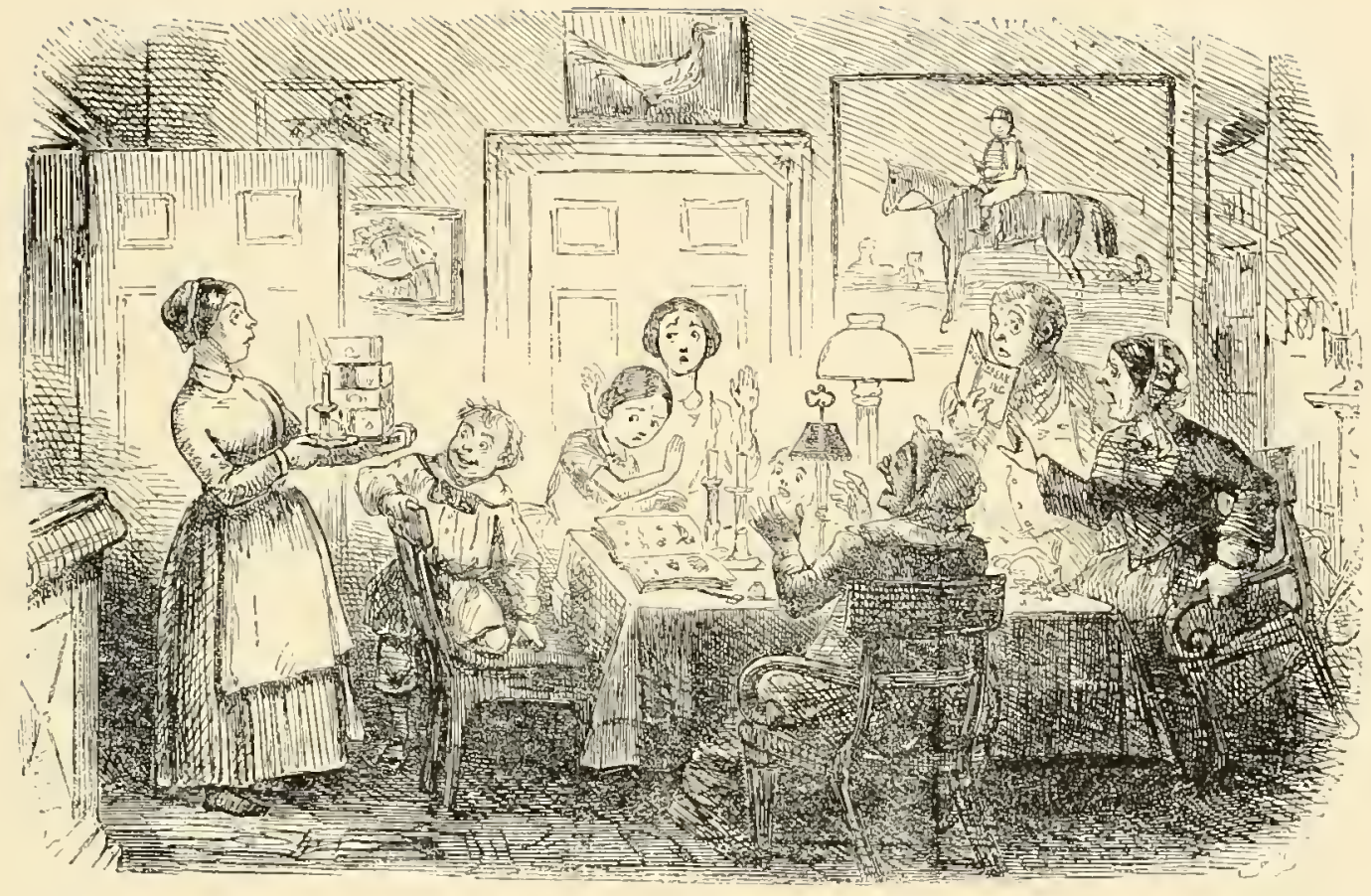

Few things are more annoying than to be short of powder when there is a chance of good sport. Mr. Briggs, feeling this, orders a good supply, to bang away at the pheasants to-morrow. He suggests to Mrs. Briggs, that it should be kept under their bed, to be out of the way of the children! 


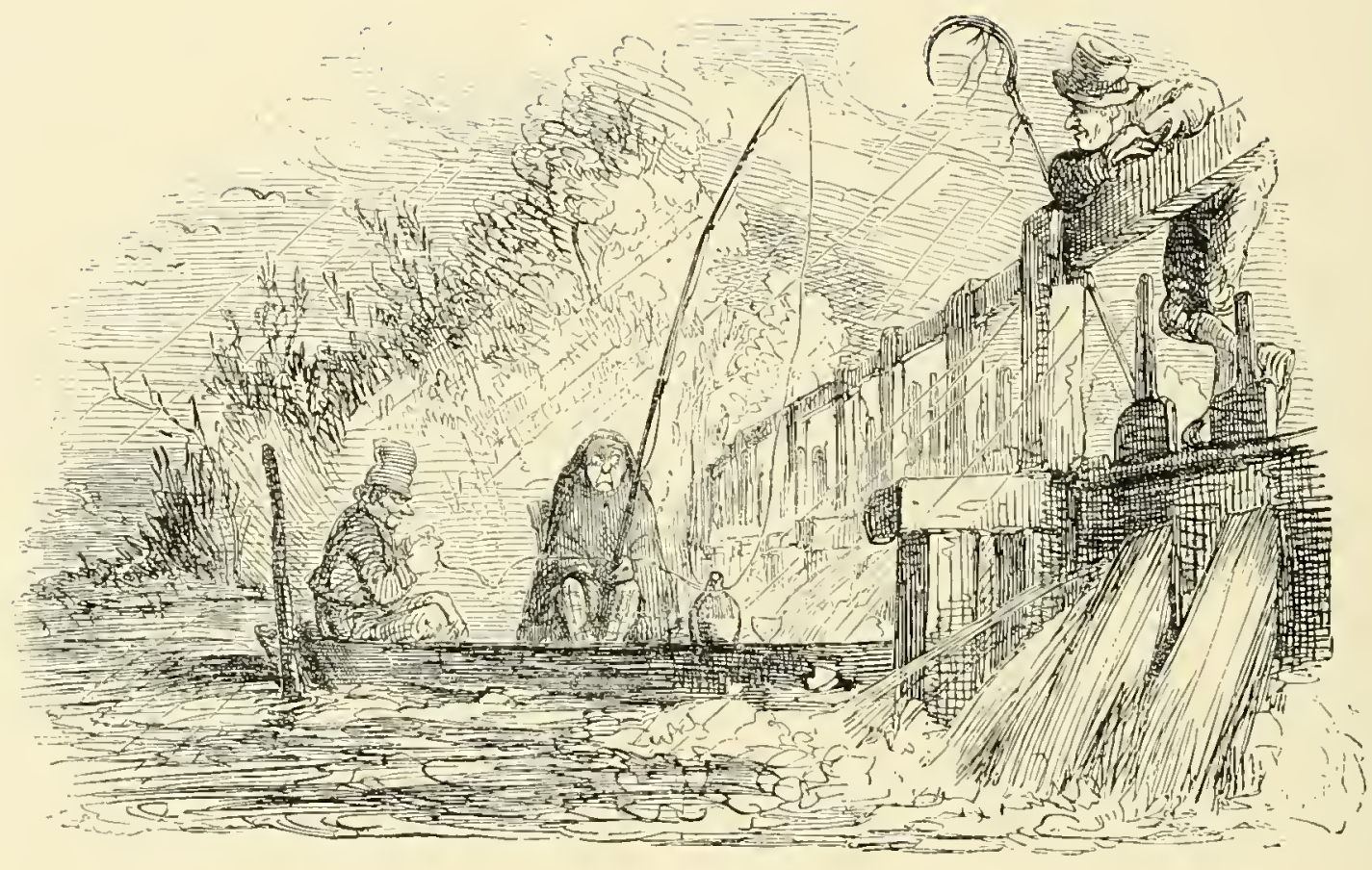

\section{CONSOLATION.}

"Not kitched none! Ah! Sir, you should ha' bin here last Toosday; there was two gents. killed a uncommon sight a' fish to be sure, then." 


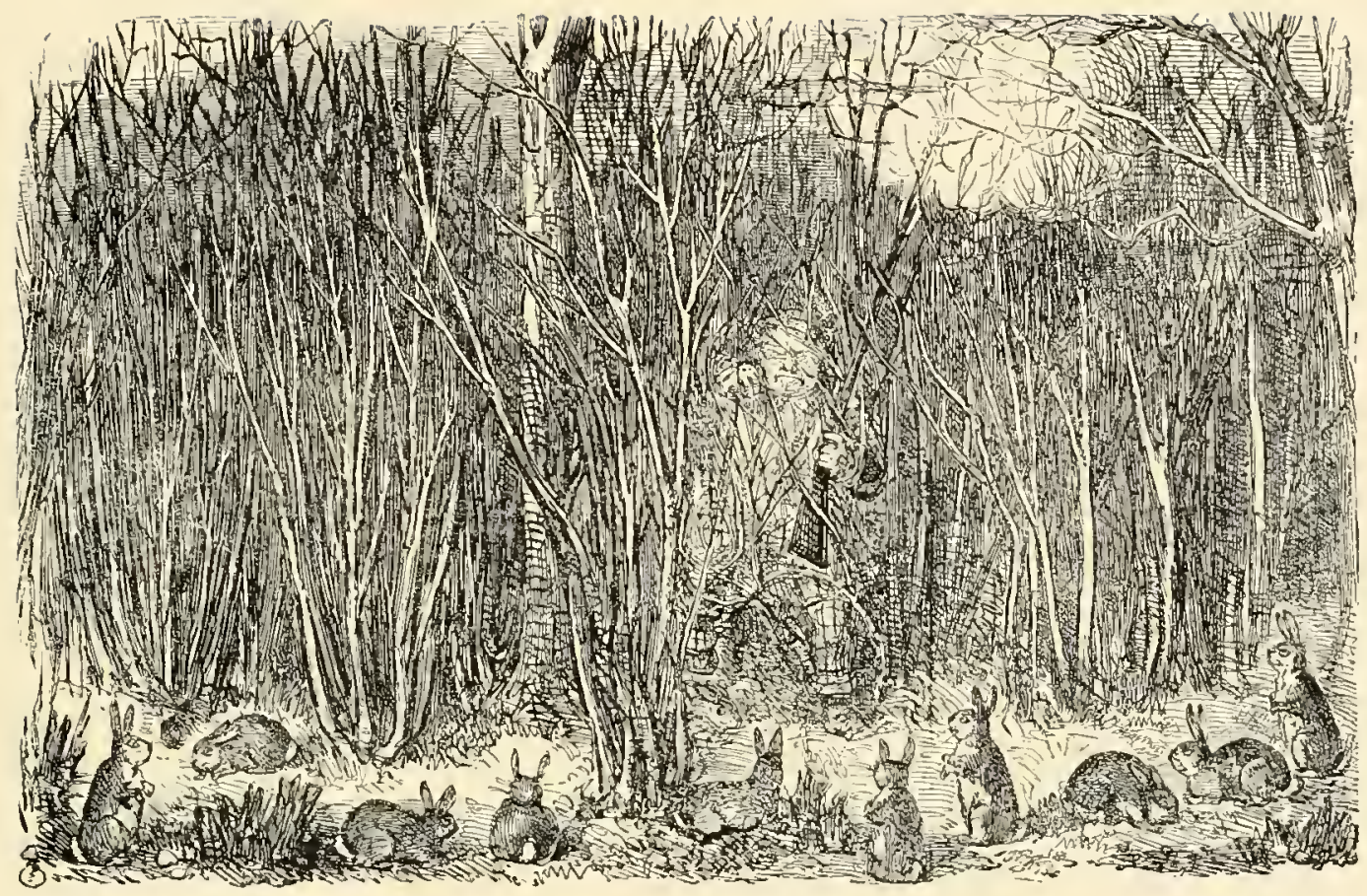

TABLEAU-REPRESENTING MR. BRIGGS OUT FOR A DAY'S RABBIT-SHOOTING. 


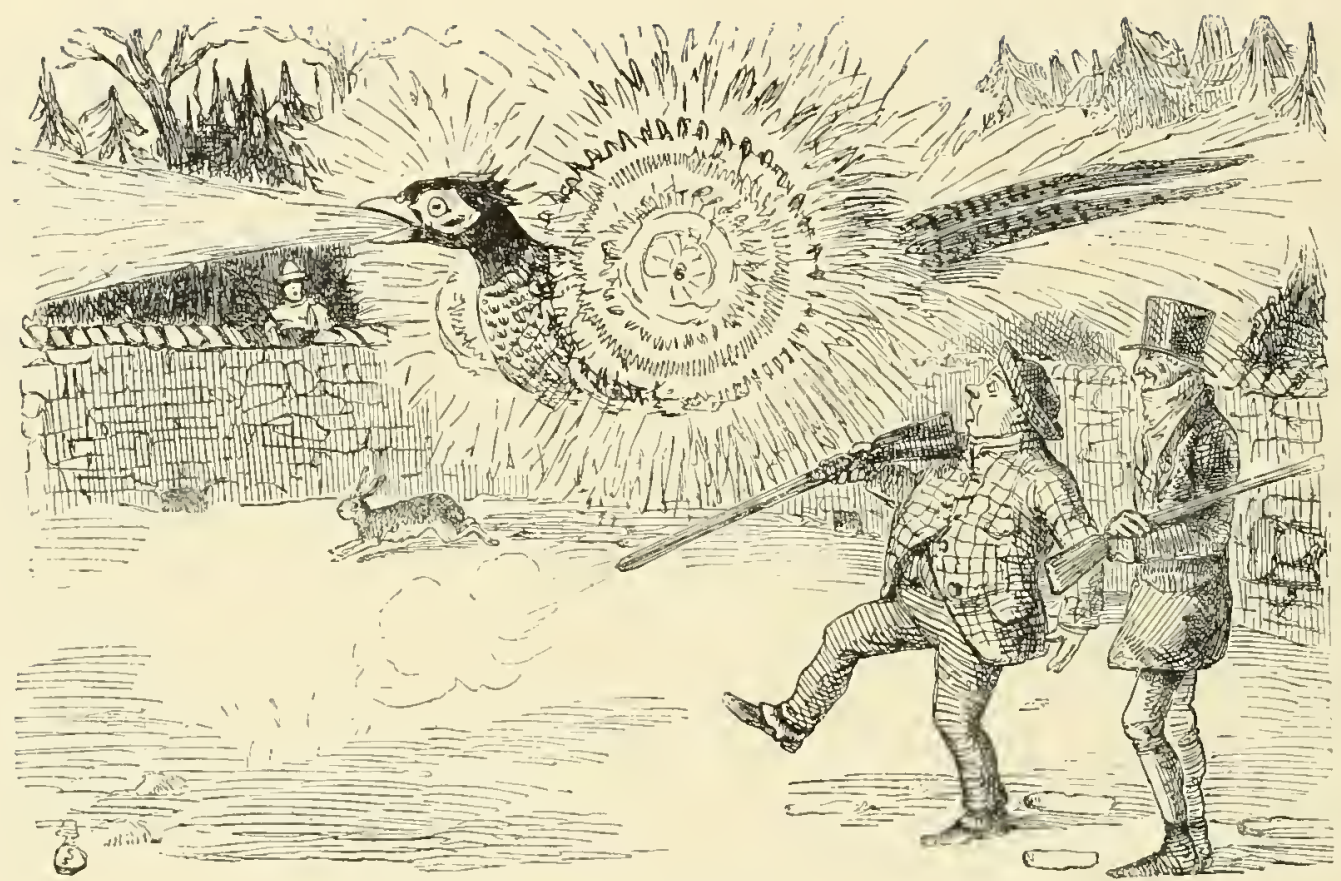

A FRIEND HAS GIVEN MR. BRIGGS A DAY'S SHOOTING.

A cock pheasant gets up, and Mr. Briggs's impression is, that a very large firework has been let off close to him. He is almost frightened to death. 


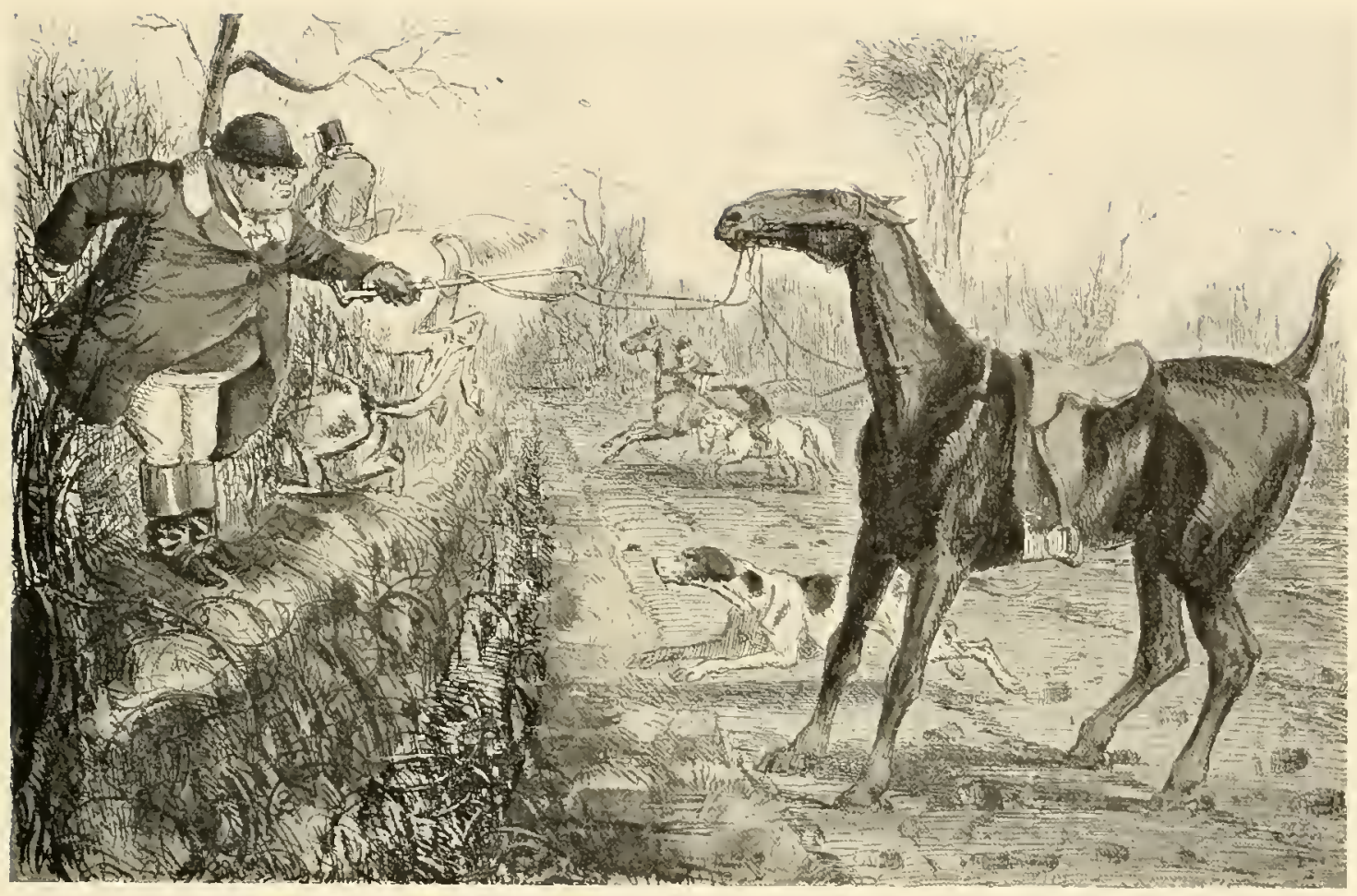

Mr. Jorrocks (loq.). "Come hup! I say,-you ugly Beast."-From "Handley Cross." 


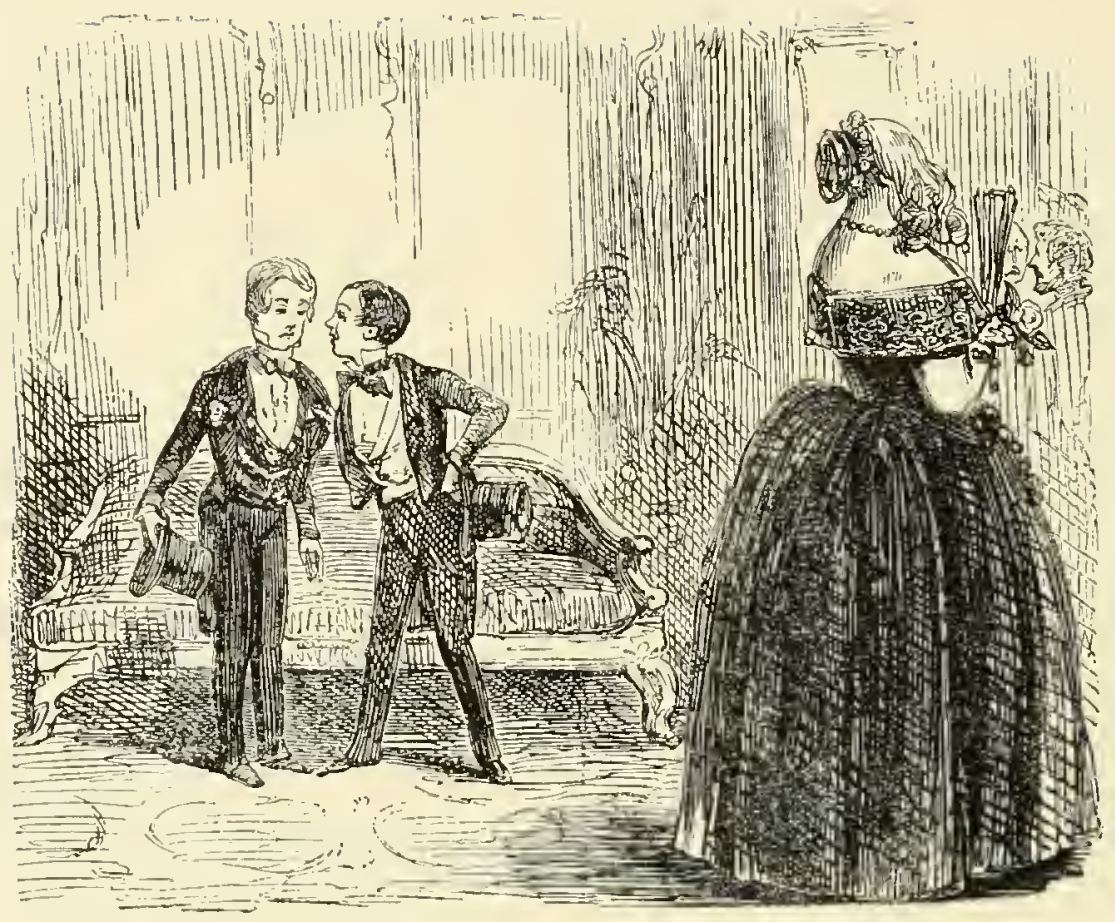

THE RISING GENERATION.

Juvenile. "Oh, Charley. If you hear a report that I'm going to be married to that girl in black, you can contradict it. There's nothing in it." 


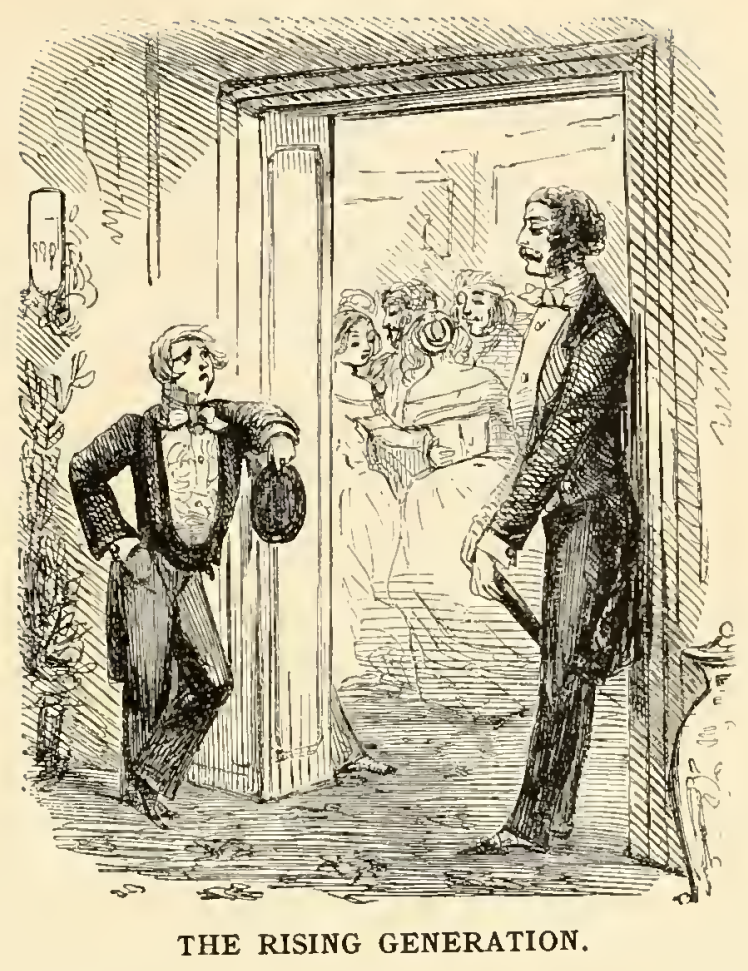

Juvenile Oxford Man (who does not think Vin Ordinaire of himsclf). "A-were you at either University ?" Awful Swell. "Ya-as-when I was a-boy!" (Oxford man departs in a Hansom.) 


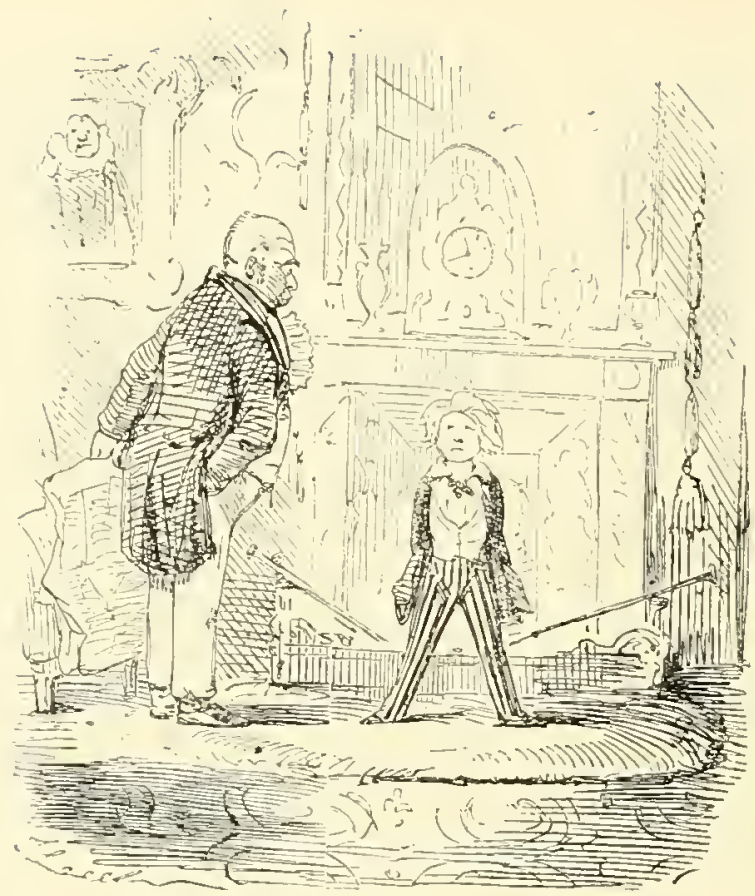

THE RISING GENERATION.

Juvenile. "I tell you what it is, Governor, the sooner we come to some understanding the better. You can't expect a young feller to be always at home; and if you don't like the way I go on, why I must have chambers, and so much a-week!" 


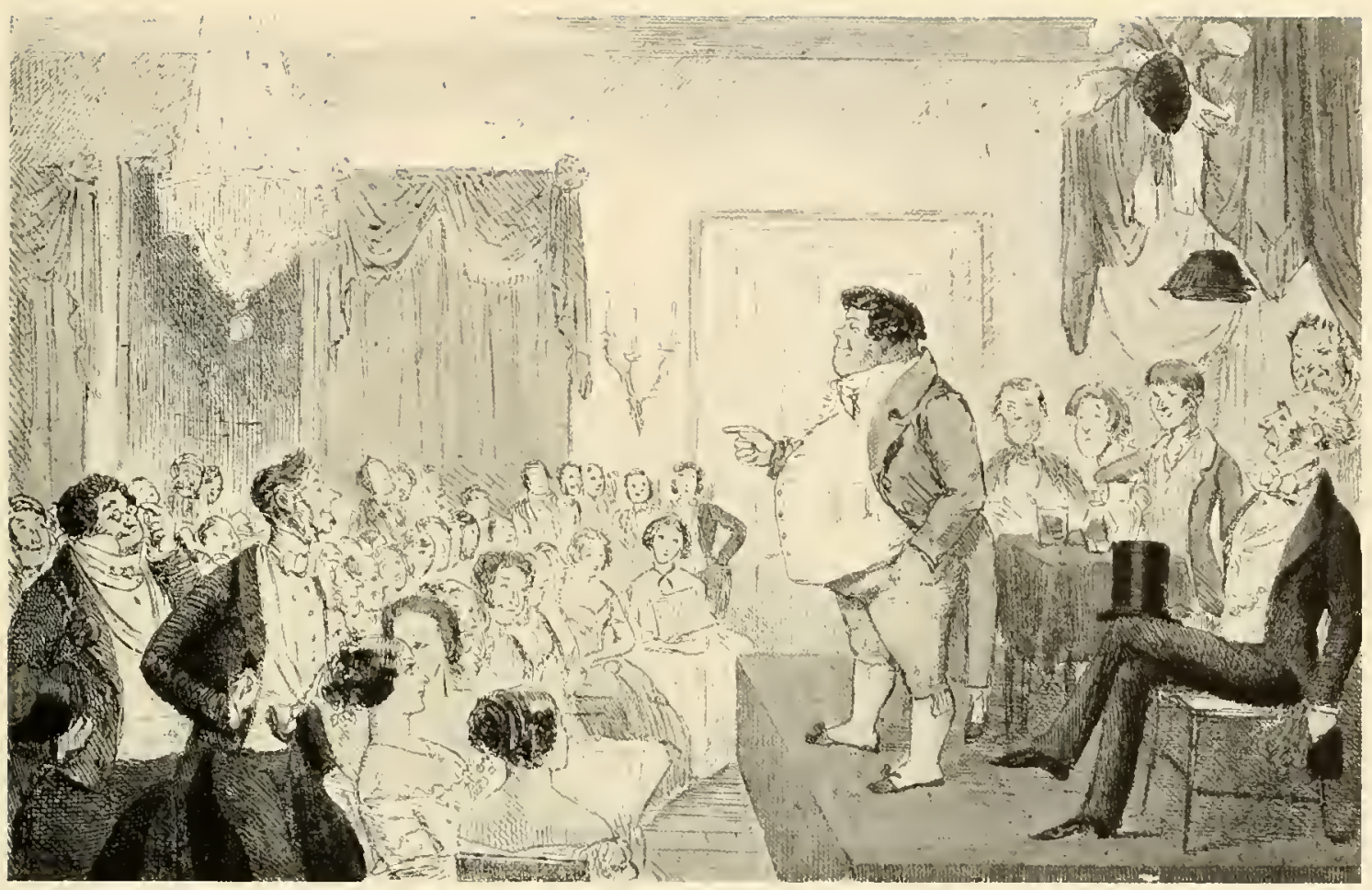

Mr. Jorrocks's Lecture on " 'Unting." -From "Handley Cross." 


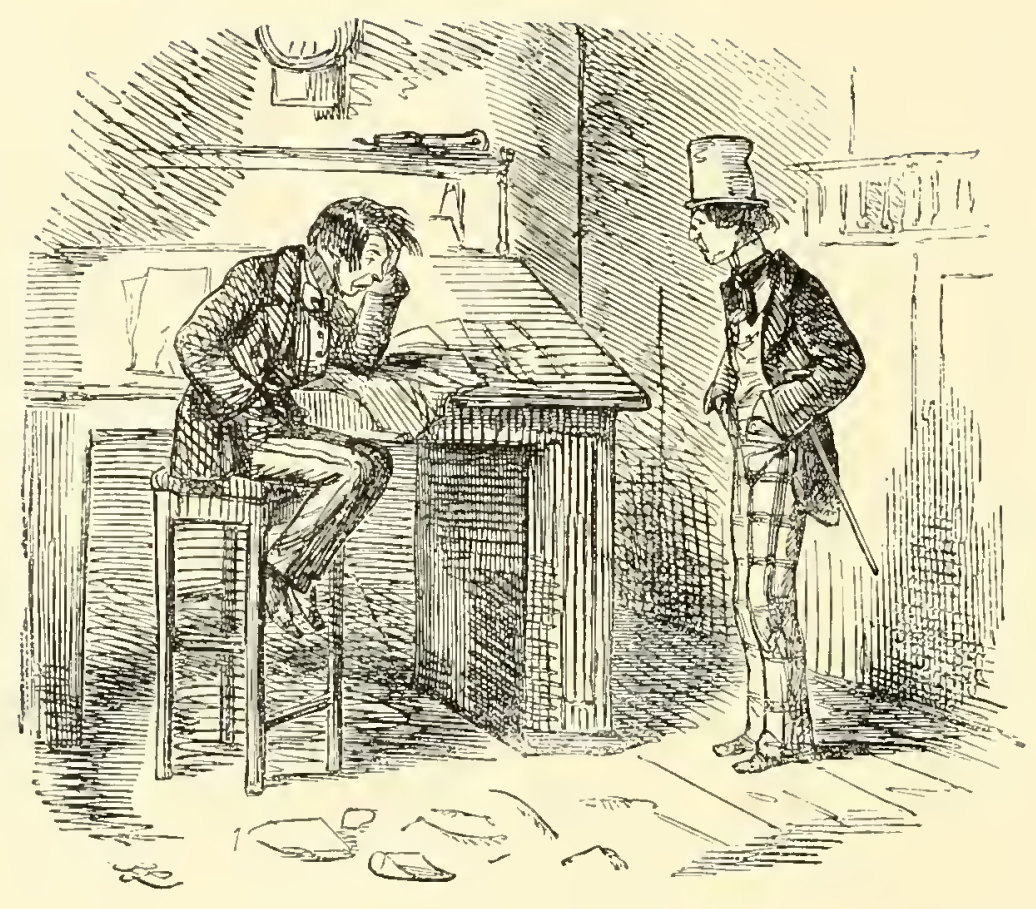

THE MORNING AFTER THE DERBY.

First Gcnt. "Well, Ned, how did we get home last night?"

Second Gcul. "Oh, I don't know! Didn't I go home with you? " 


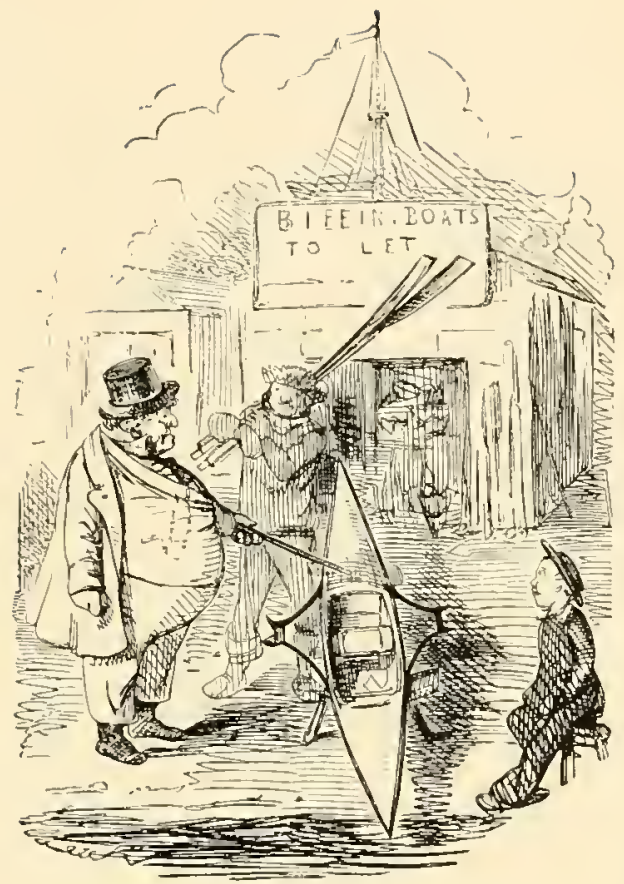

A BOAT FOR AN HOUR.

Stout Gentleman. "What! is that the only boat you have in?" 


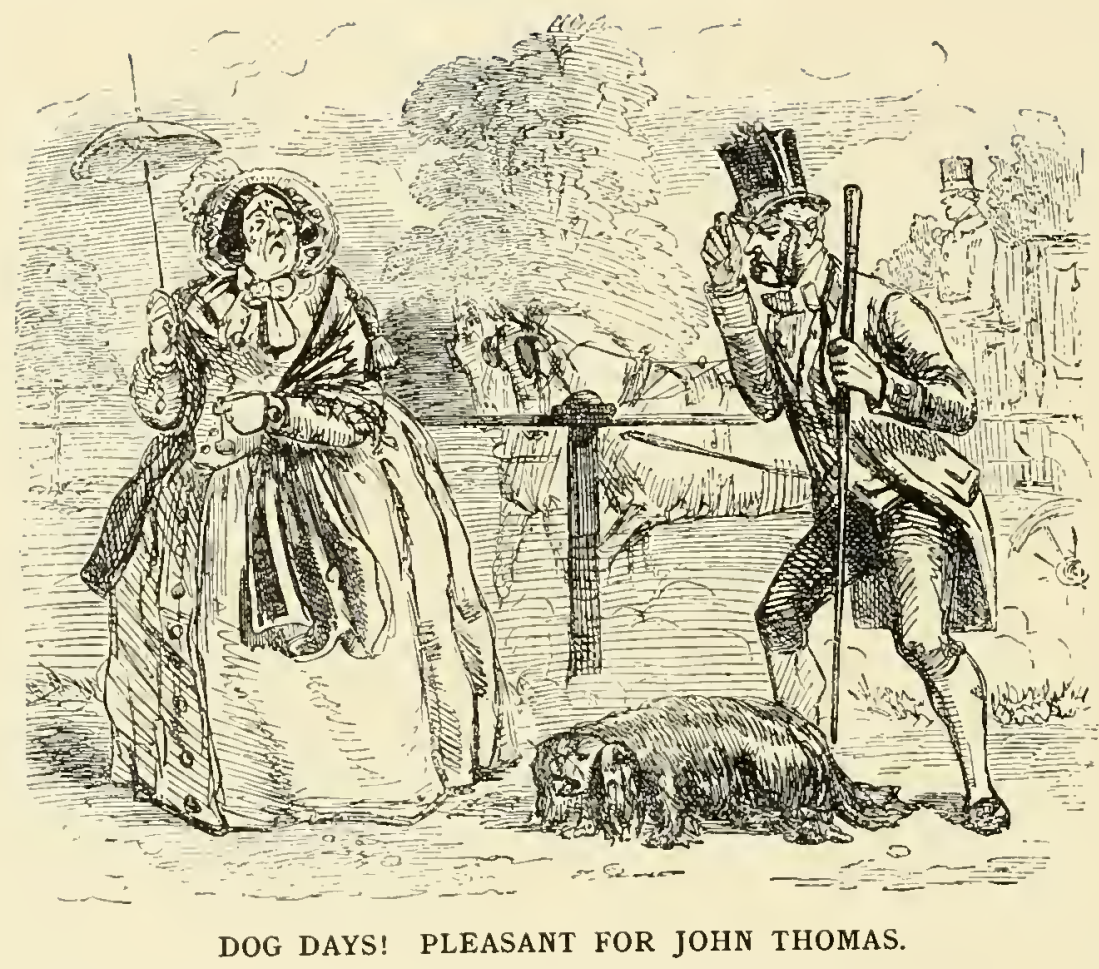

Old Lady. " John Thomas!"

John Thomas. "Yes, my lady!"

Old Lady. " Carry Esmeralda-she's getting tired, poor darling!" 


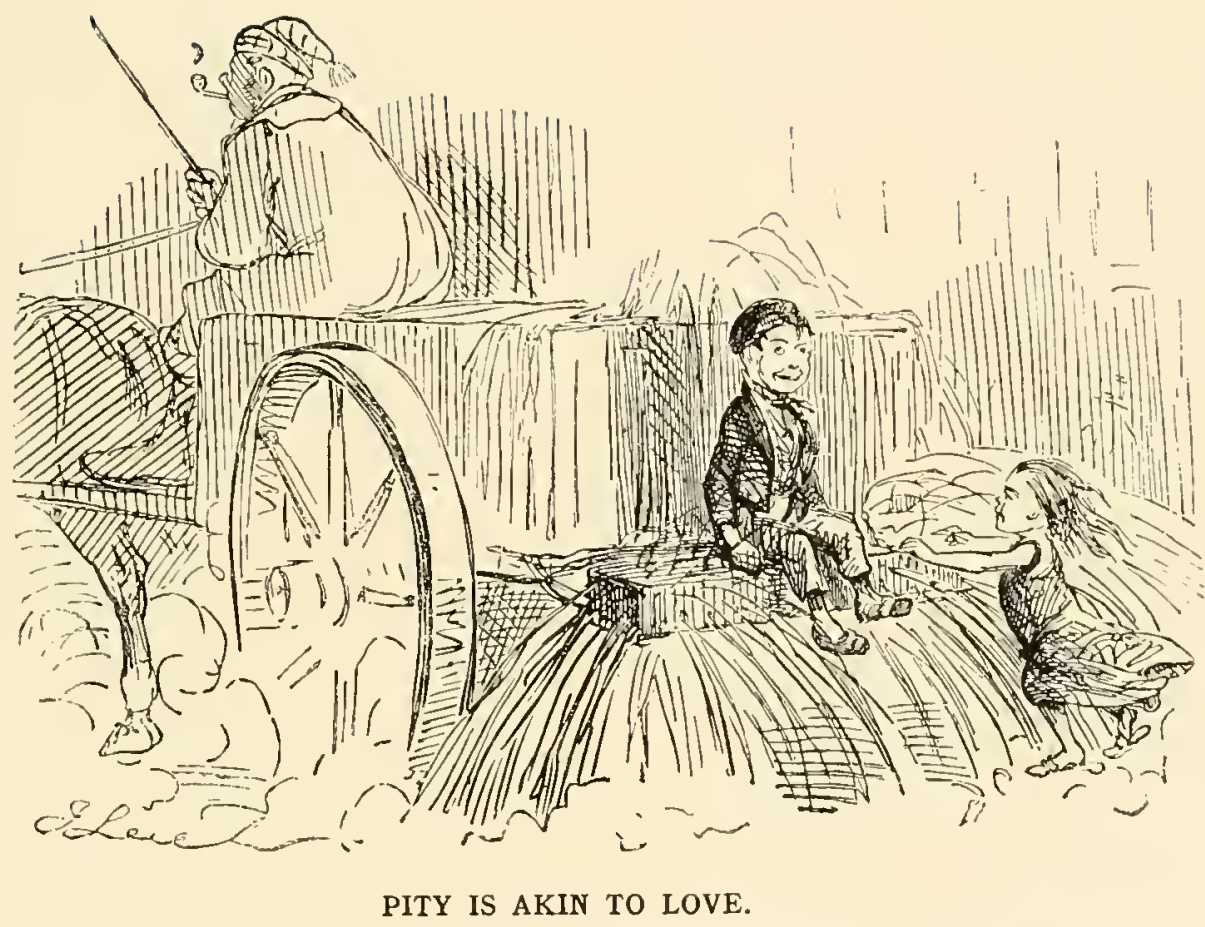

Boy (loq.). "O don't I pity them poor nobs in carridges this hot weather!" 


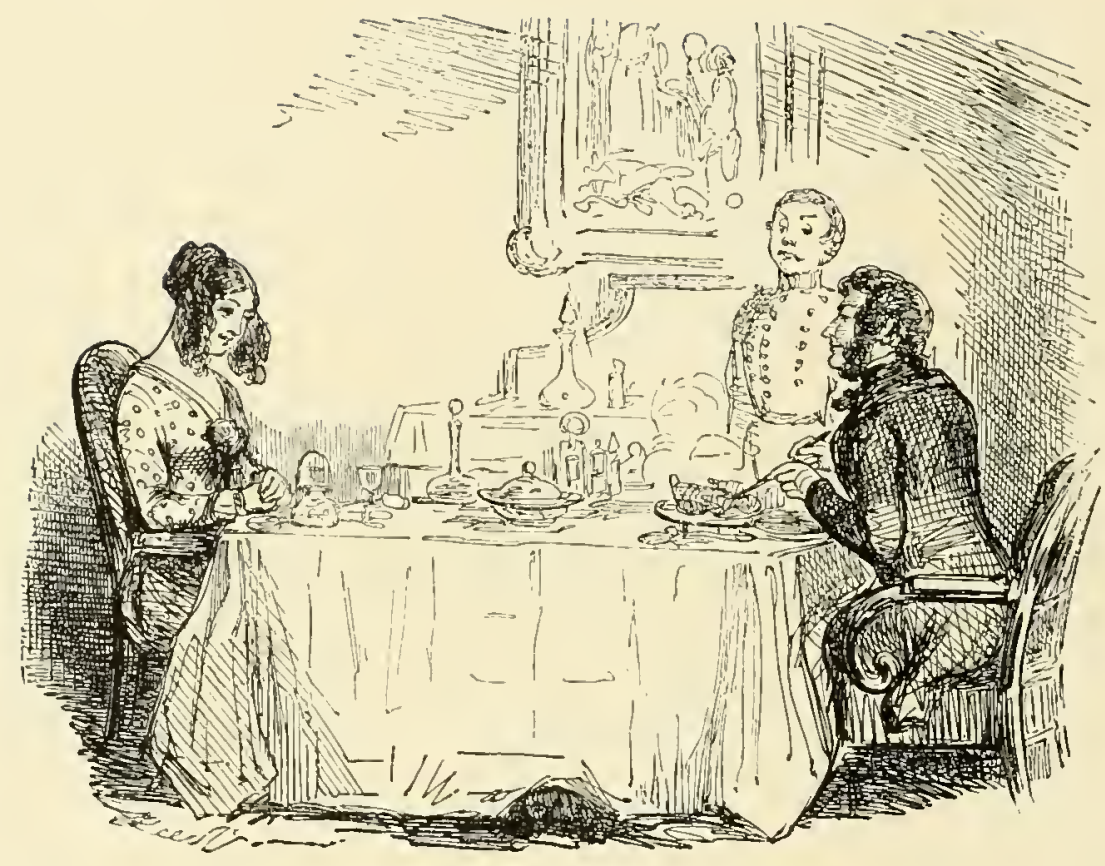

A ROMANCE OF ROAST DUCKS.

"My darling, will you take a little of the-a-the stuffing?"

"I will, dear, if you do; but if you don't, I won't." 


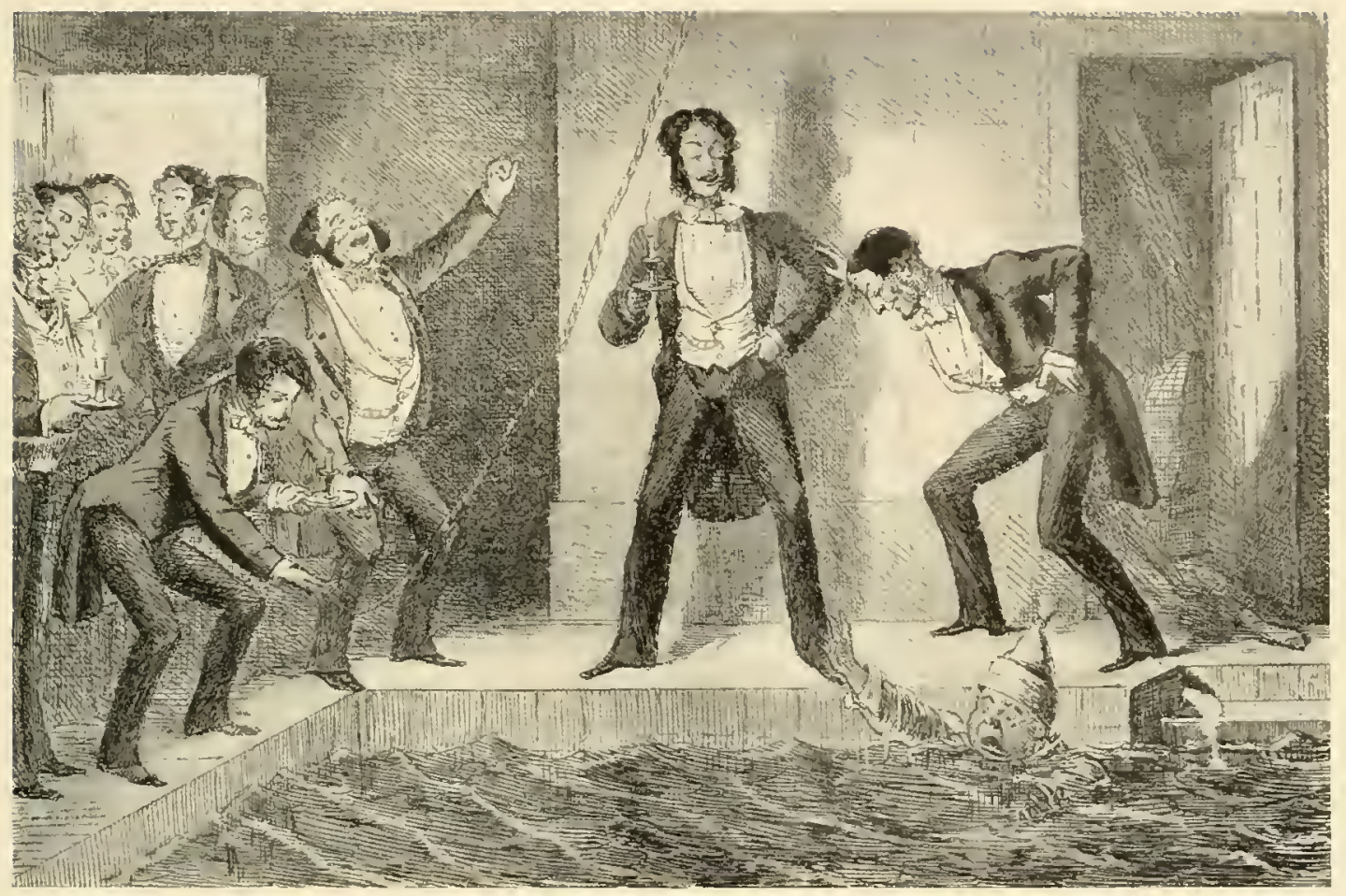

Mr. Jorrocks's Bath.-From " Handley Cross." 


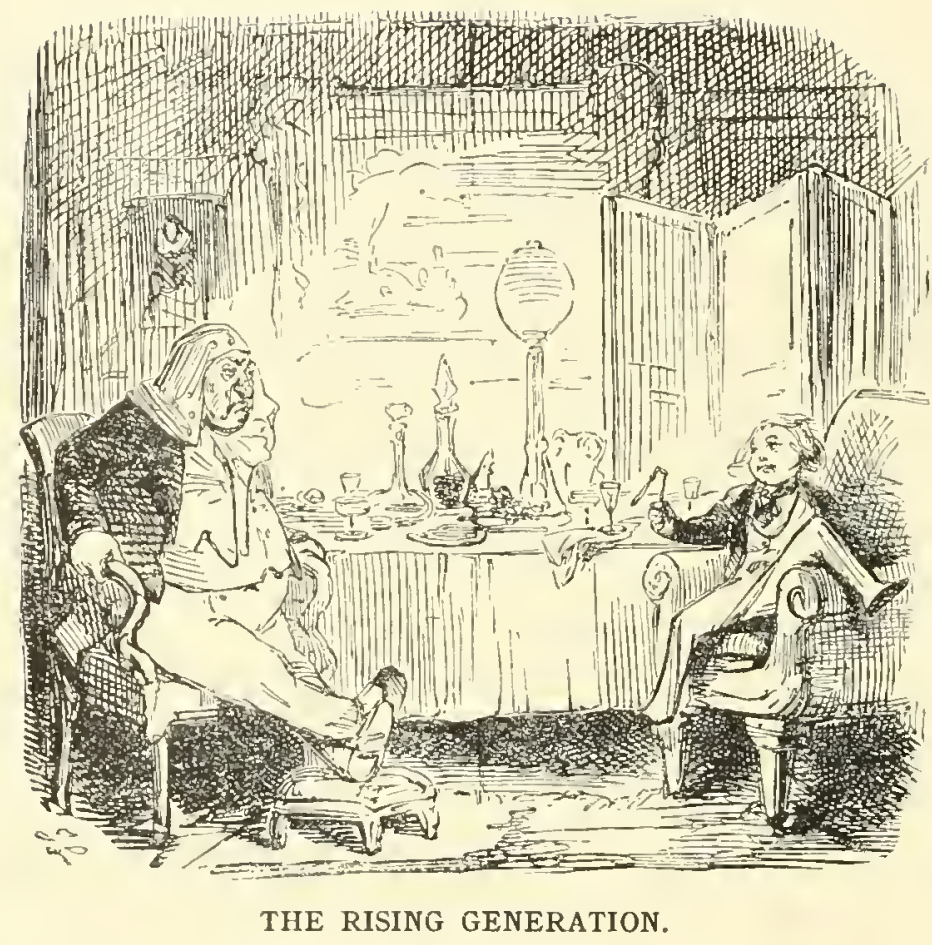

Juenile. "Uncle!"

Unule. "Now then, what is it? This is the fourth time you've woke me up, Sir!"

Juvenile. "Oh! just put a few coals on the fire, and pass the wine, that's a good old chap." 


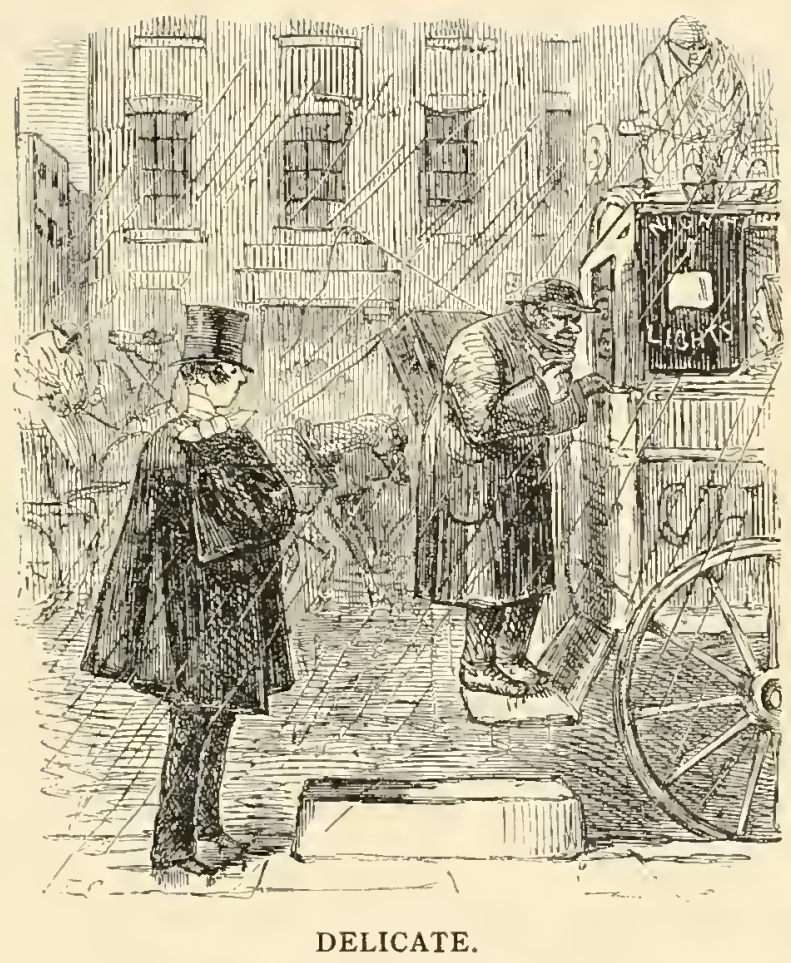

'Bus Conductor. "Would any lady be so kind as to ride outside to oblige a gentleman?" 


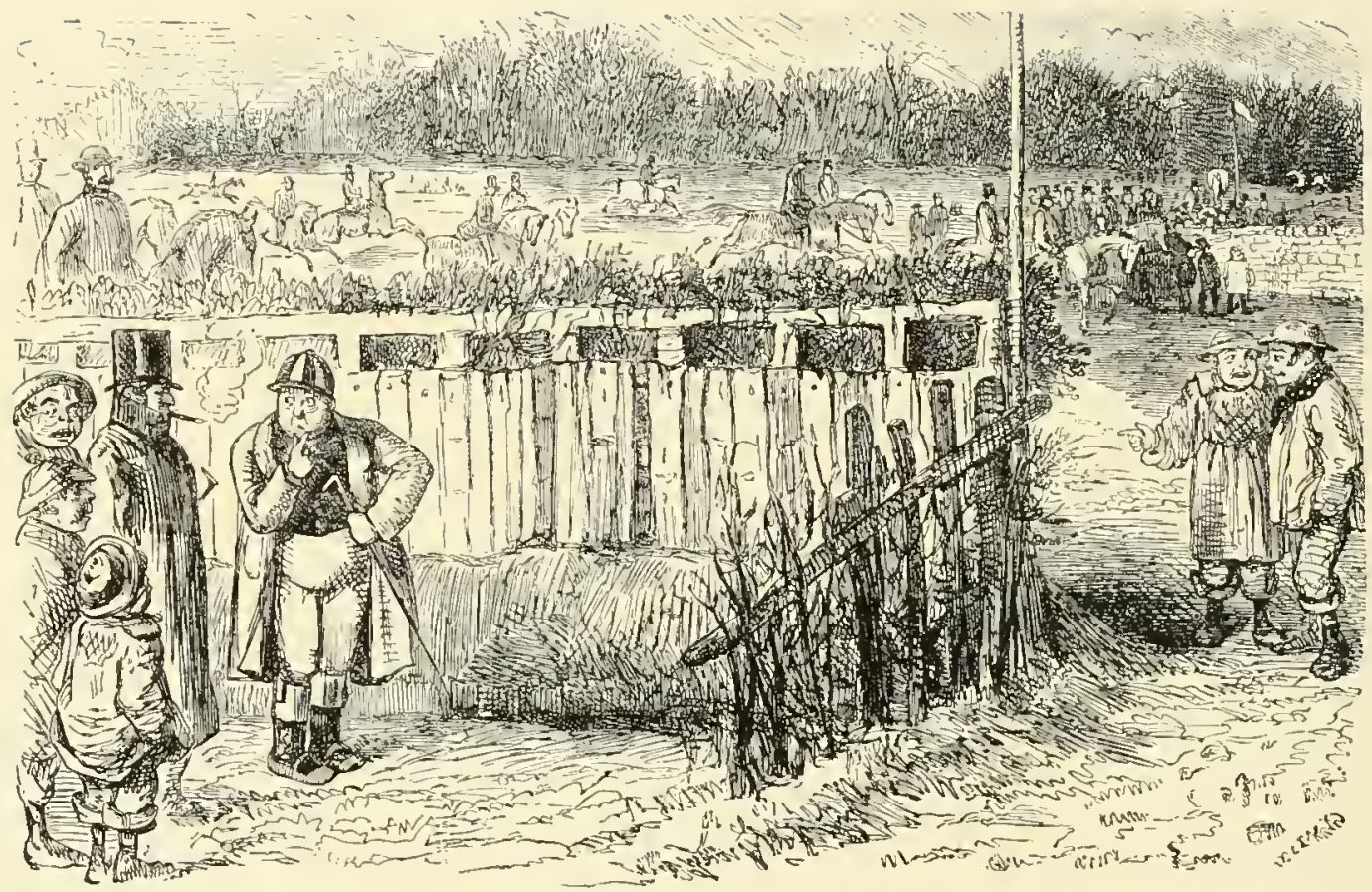

MR. BRIGGS HAS BACKED HIMSELF TO RIDE A STEEPLE CHASE AGAINST HIS FRIEND MUFFINS, OF THE ST-K EXCH-NGE. HE IS GOING ROUND THE COURSE JUST TO LOOK AT THE JUMPS.

Spcctator (to Mr. B.). "Oh no, Sir! - This ain't the big one. The big one is after you get out of the lane, and afore you come to the brook!" 


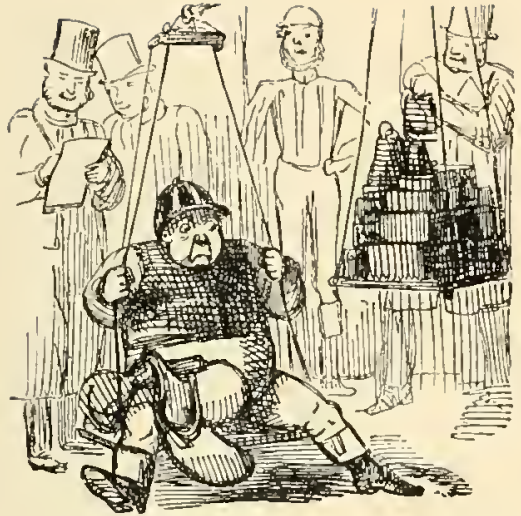

Mr. Briggs is weighed, of course.

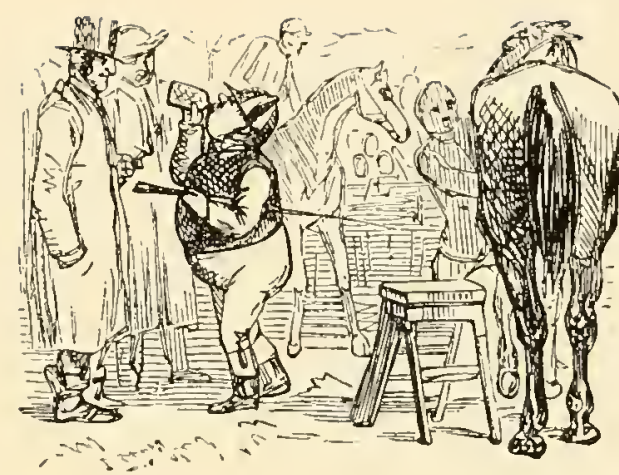

His friends recommend him a little jumping powder.

MR. BRIGGS RIDES HIS MATCH 


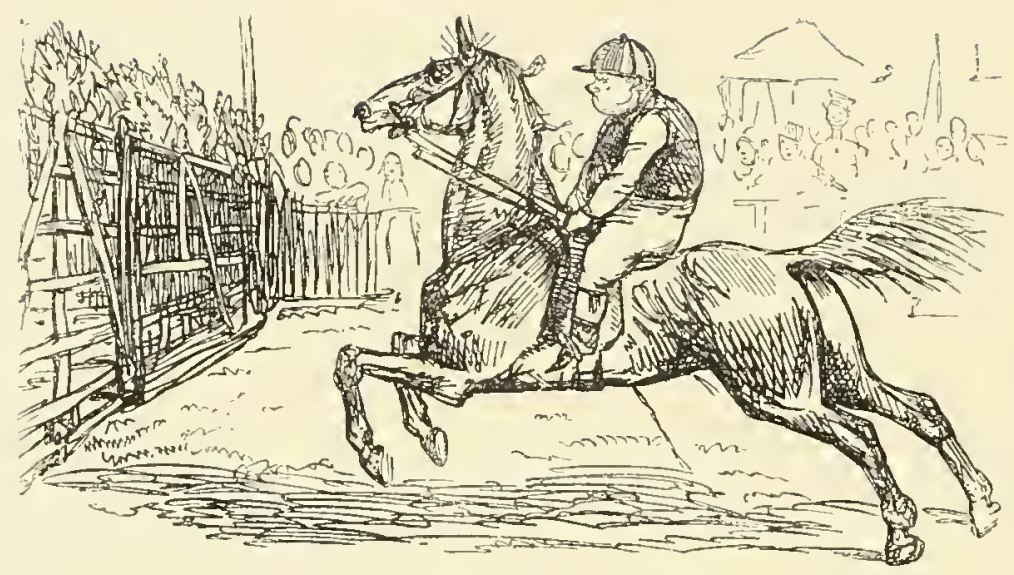

Here he takes a preliminary canter, and puts his horse at a flight of hurdles.

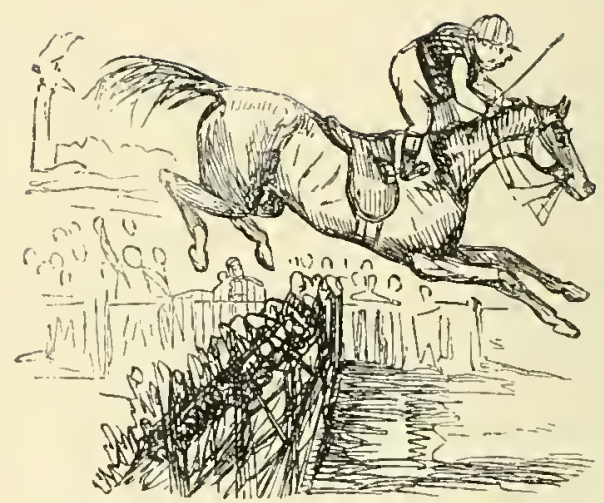

And gets over very cleverly. 


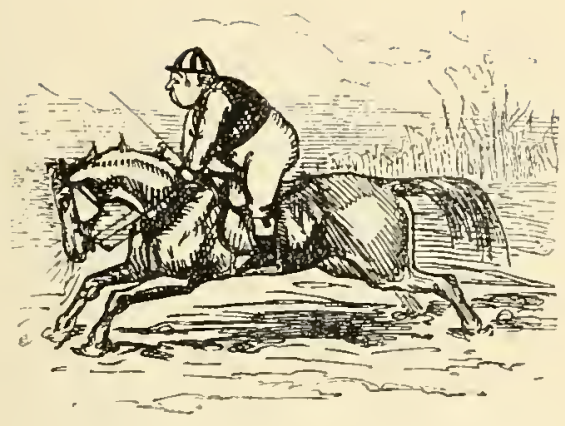

Some time after the start, Mr. Briggs goes on the wrong side of the flag, and is obliged to go back, which, as the ground is rather heavy, "takes it out of old Blunderbuss considerably."

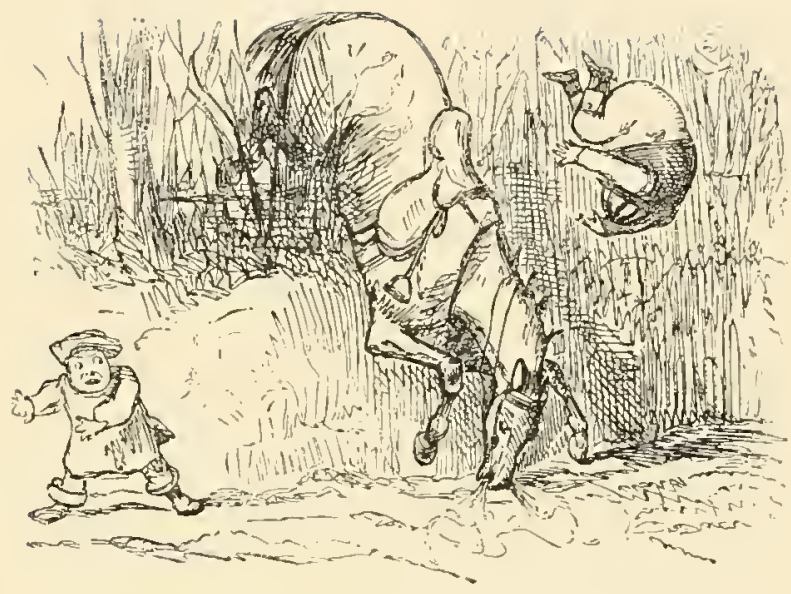

Who, in consequence, makes a mistake at the next fence. 


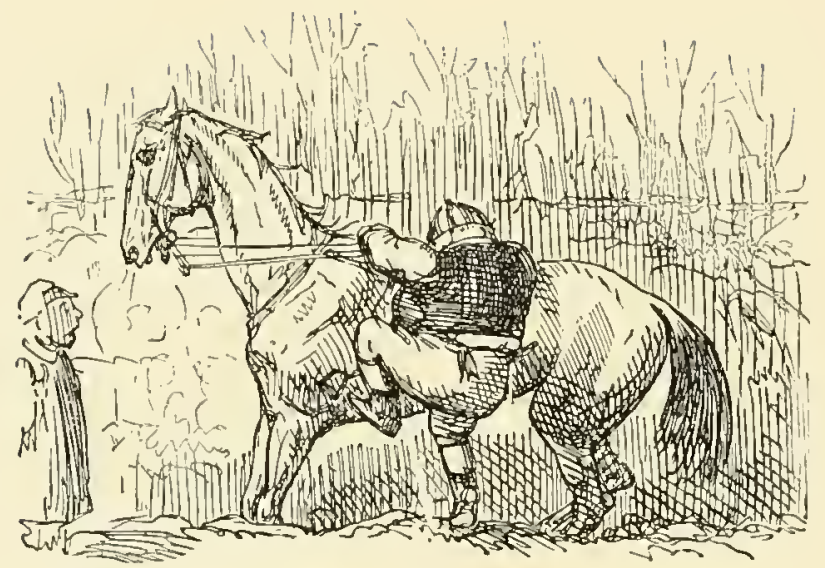

However, Mr. Briggs is not hurt; and, after some exertion re-mounts.

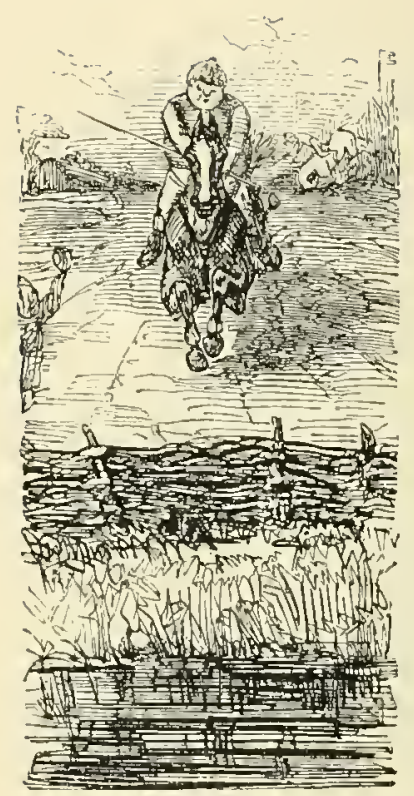

Mr. Briggs, as he appeared coming to the brook. In the distance may be observed his opponent, who has a nasty fall, but fortunately tumbles on his head. 


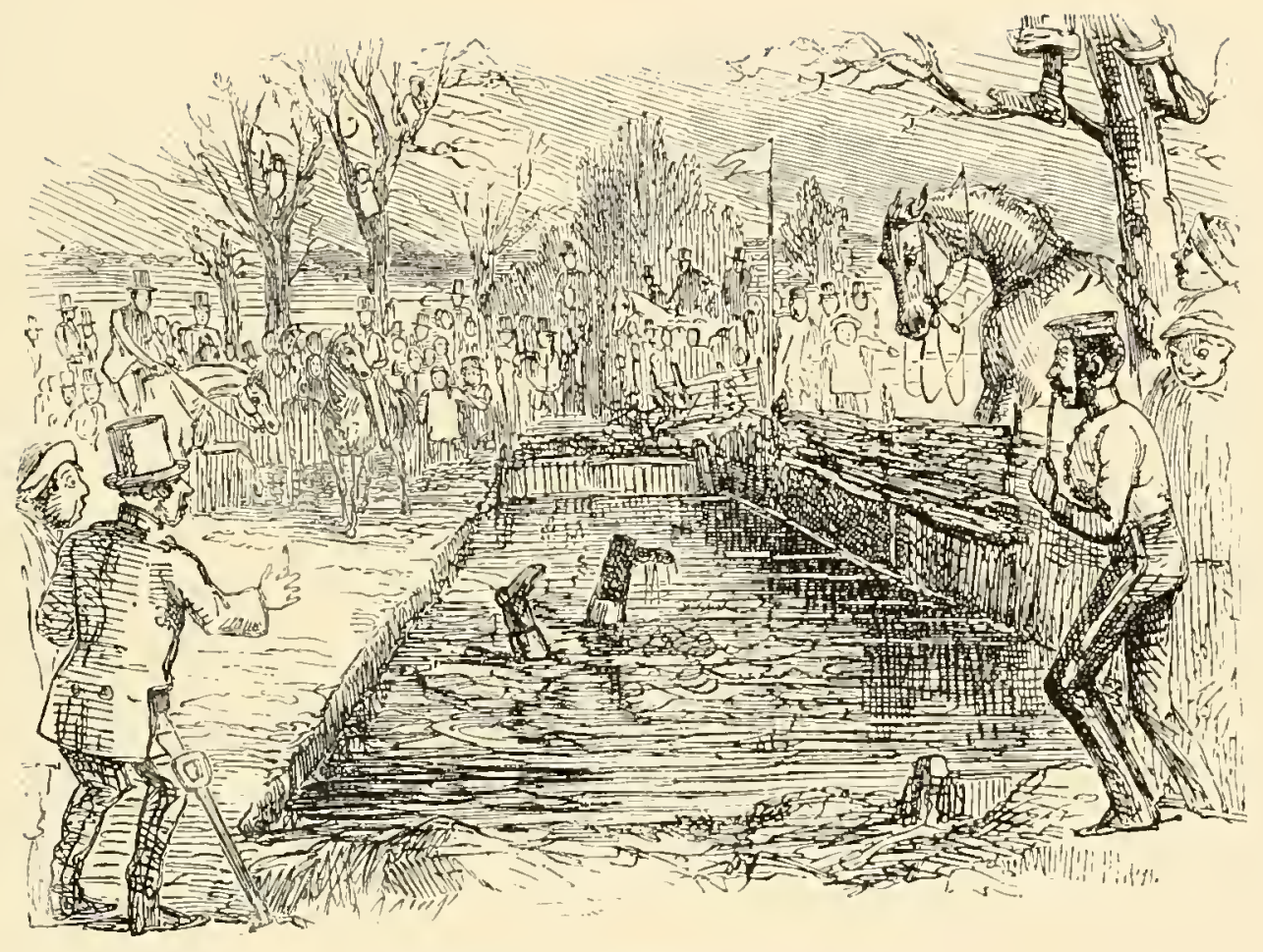

Mr. Briggs, as he appeared in the brook. 


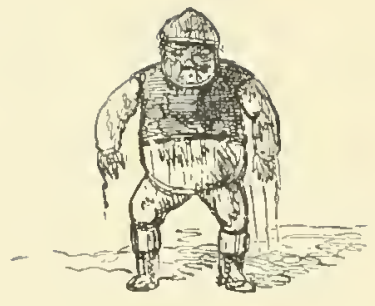

As he appeared when he came out of the brook.

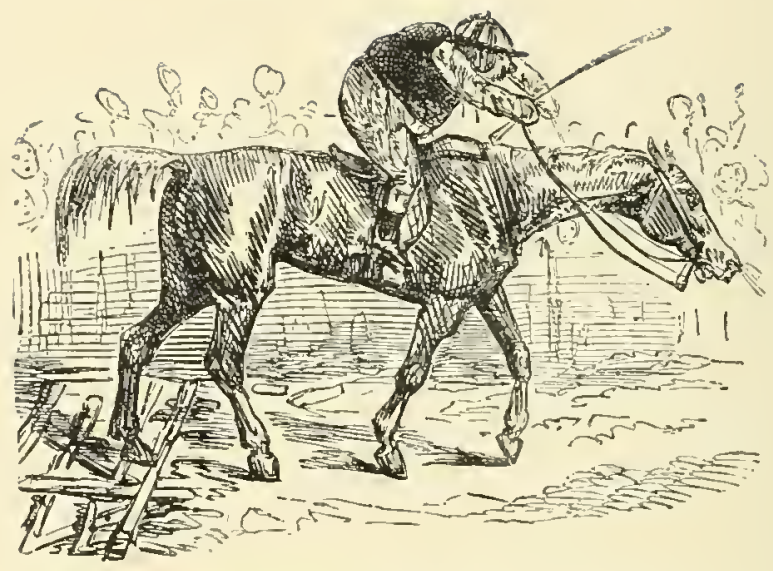

Portrait of Mr. Briggs winning the race. N.B. The dense crowd is cheering him. 


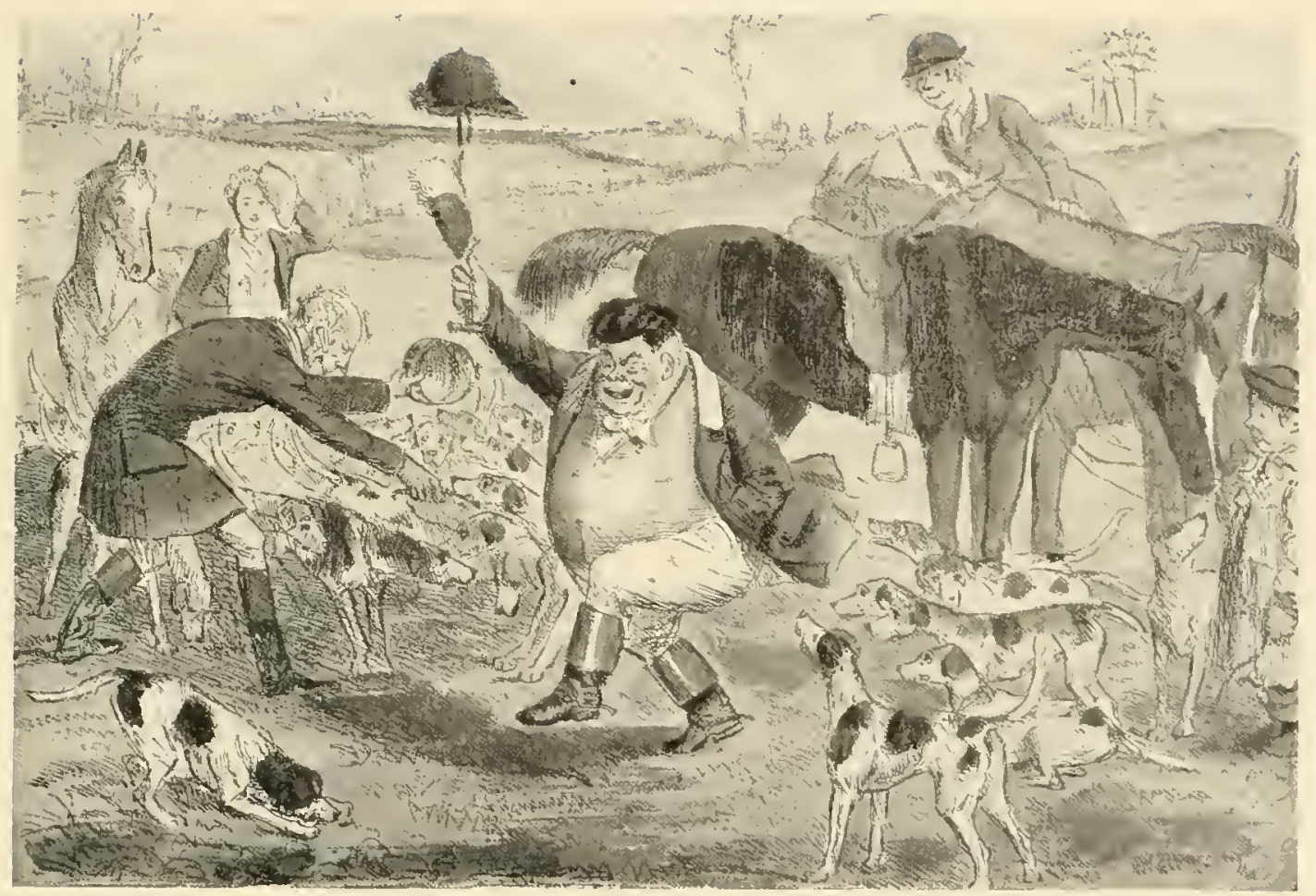

The kill, on the Cat \& Custard Pot Day.-Fron "Handley Cross." 


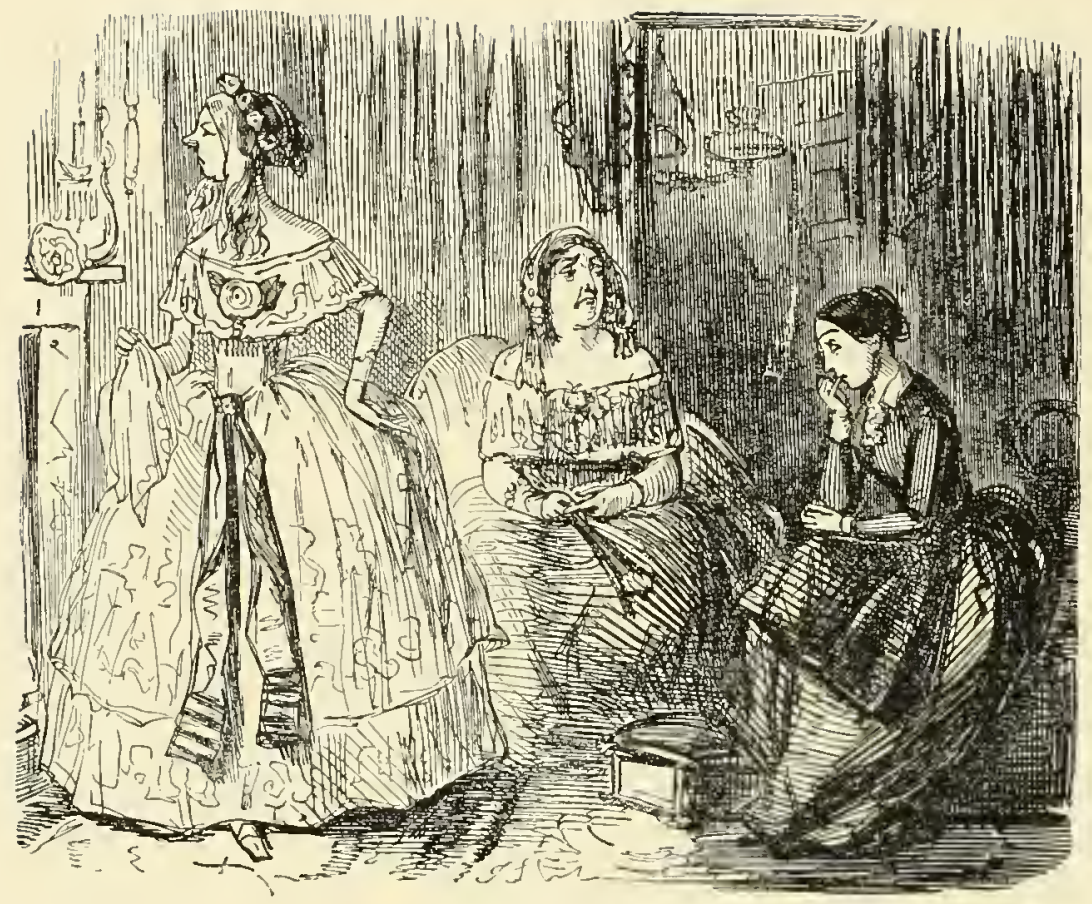

RATHER A BAD LOOK-OUT.

Young Sister. "I should so like to go to a party, Ma."

Mamma. "My dear, don't be ridiculous. As I have told you before (I am sure a hundred and fifty times), that until Flora is married, it is utterly impossible for you to go out; so do not allude to the subject again, I beg." 


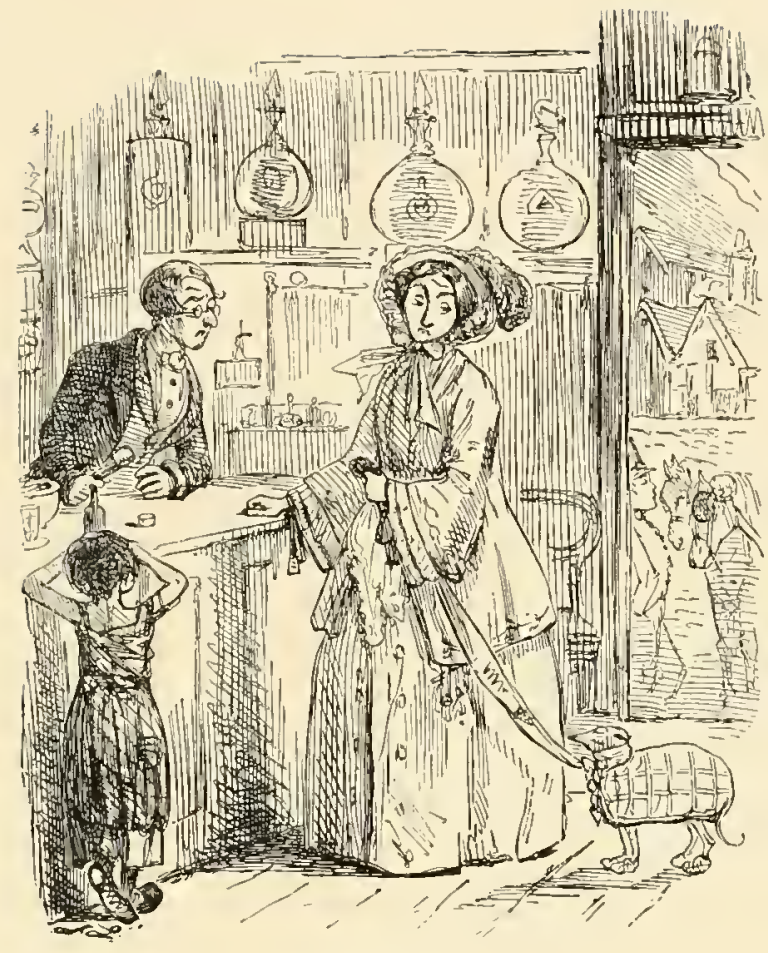

INTERESTING.

"I have called, Mr. Squills, to say that my darling little dog (!) has taken all his mixture, but his cough is no better." 


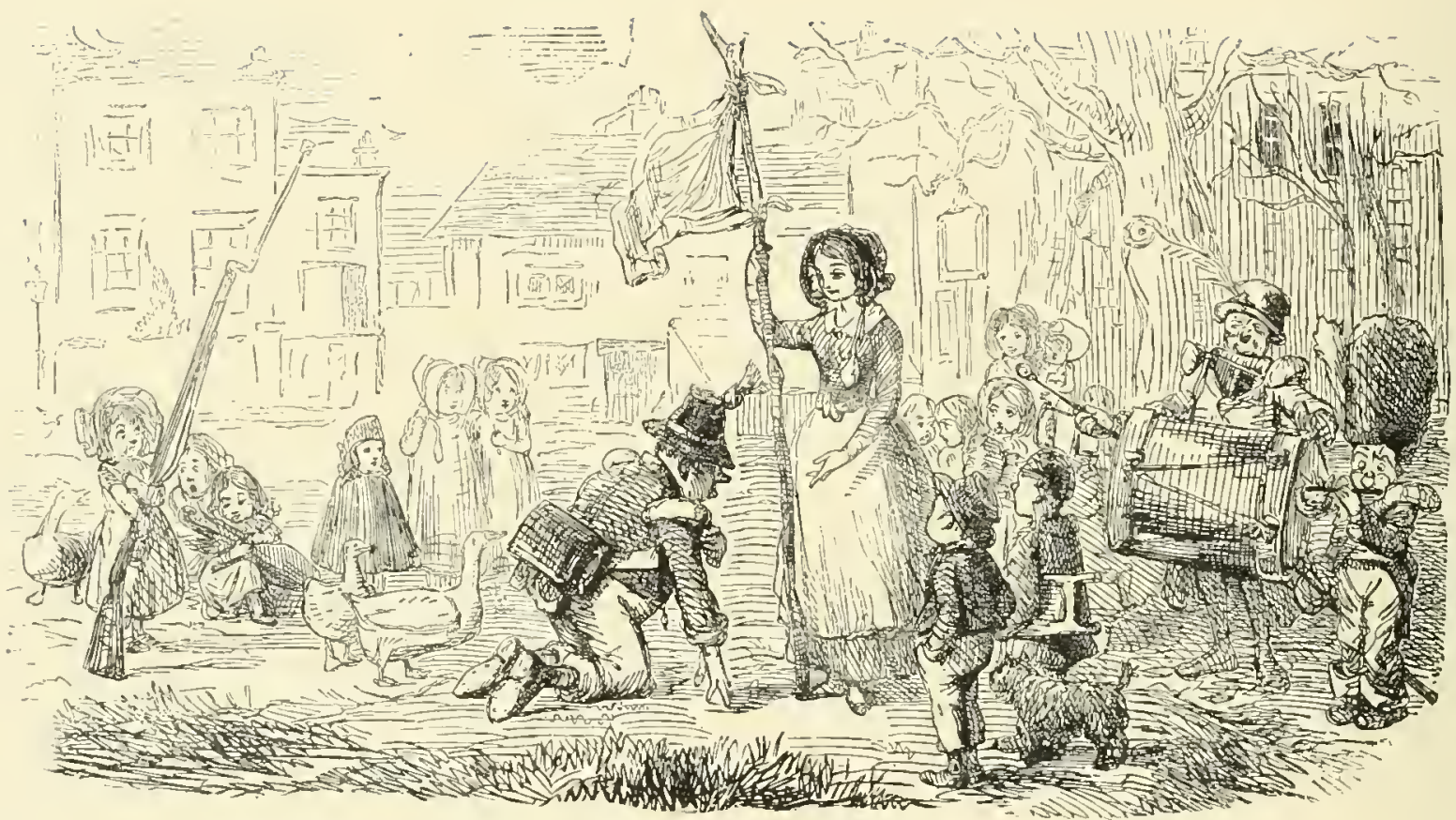

PRESENTATION OF COLOURS TO THE BROOK-GREEN VOL JNTEER. 


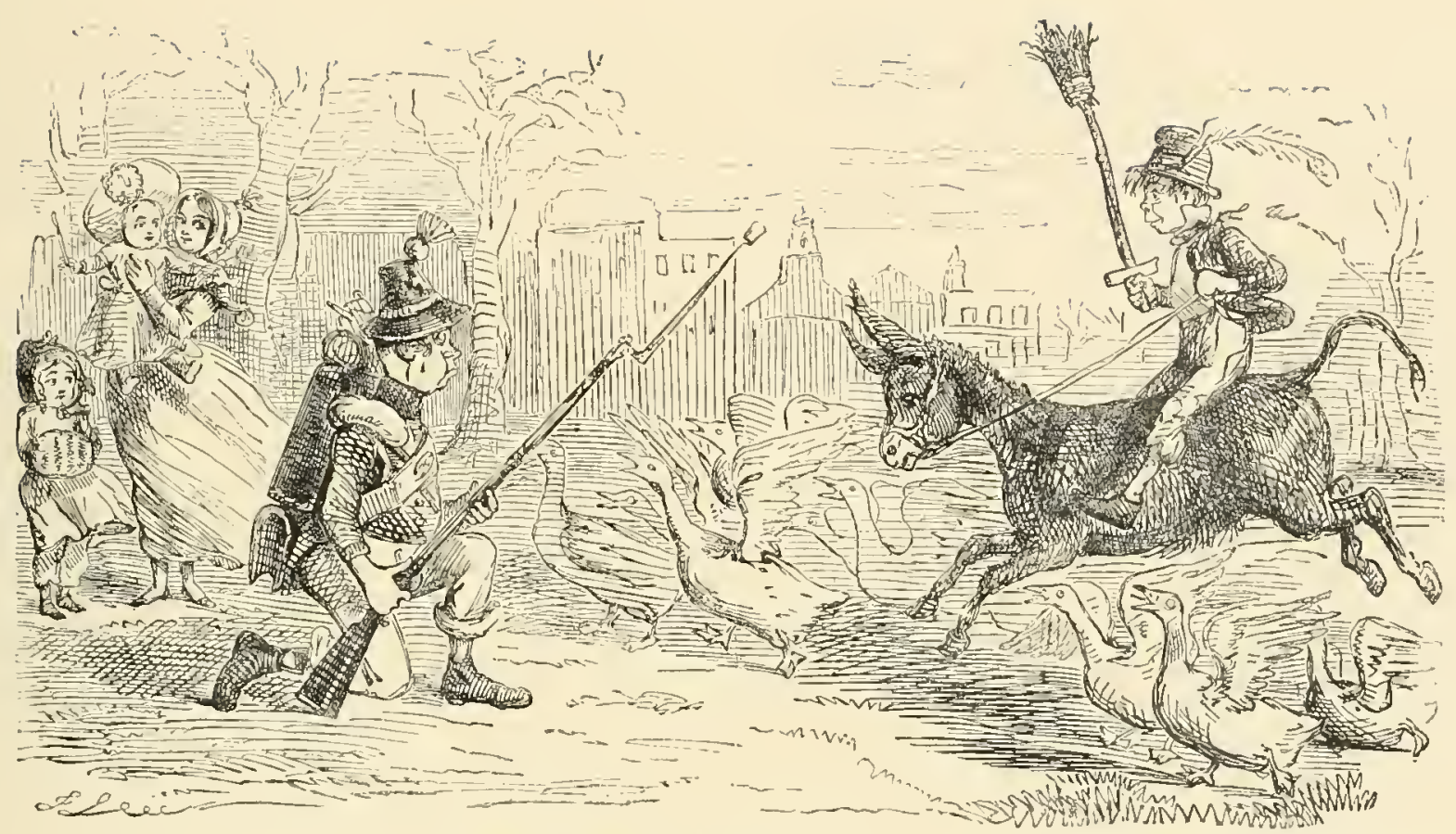

THE BROOK-GREEN VOLUNTEER FORMS HIMSELF INTO A SQUARE, AND RESISTS A CHARGE OF CAVALRY. 


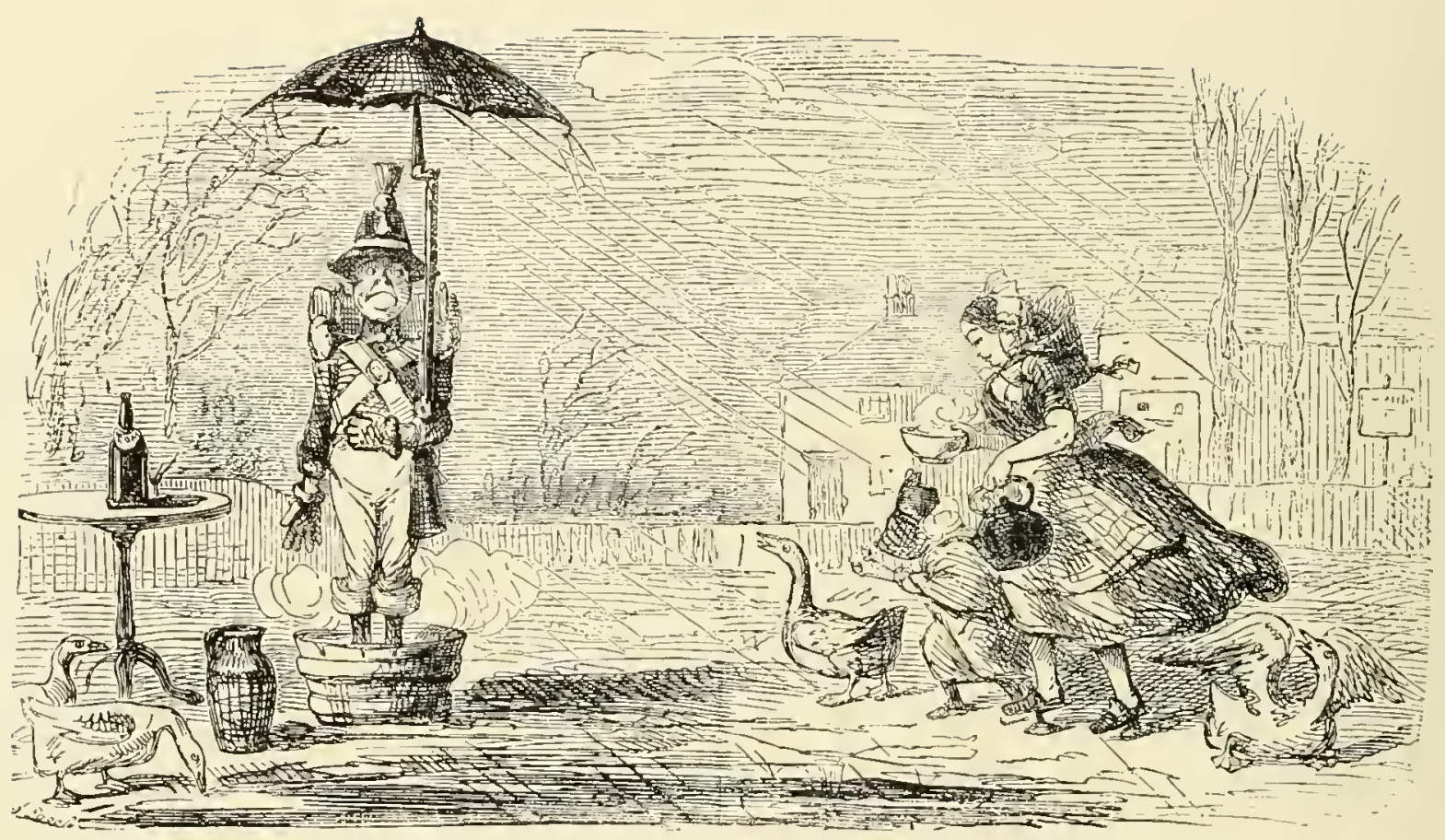

THE BROOK-GREEN VOLUNTEER.

Having a cold in his head, resorts to an ingenious method of preserving his health without deserting his post. 


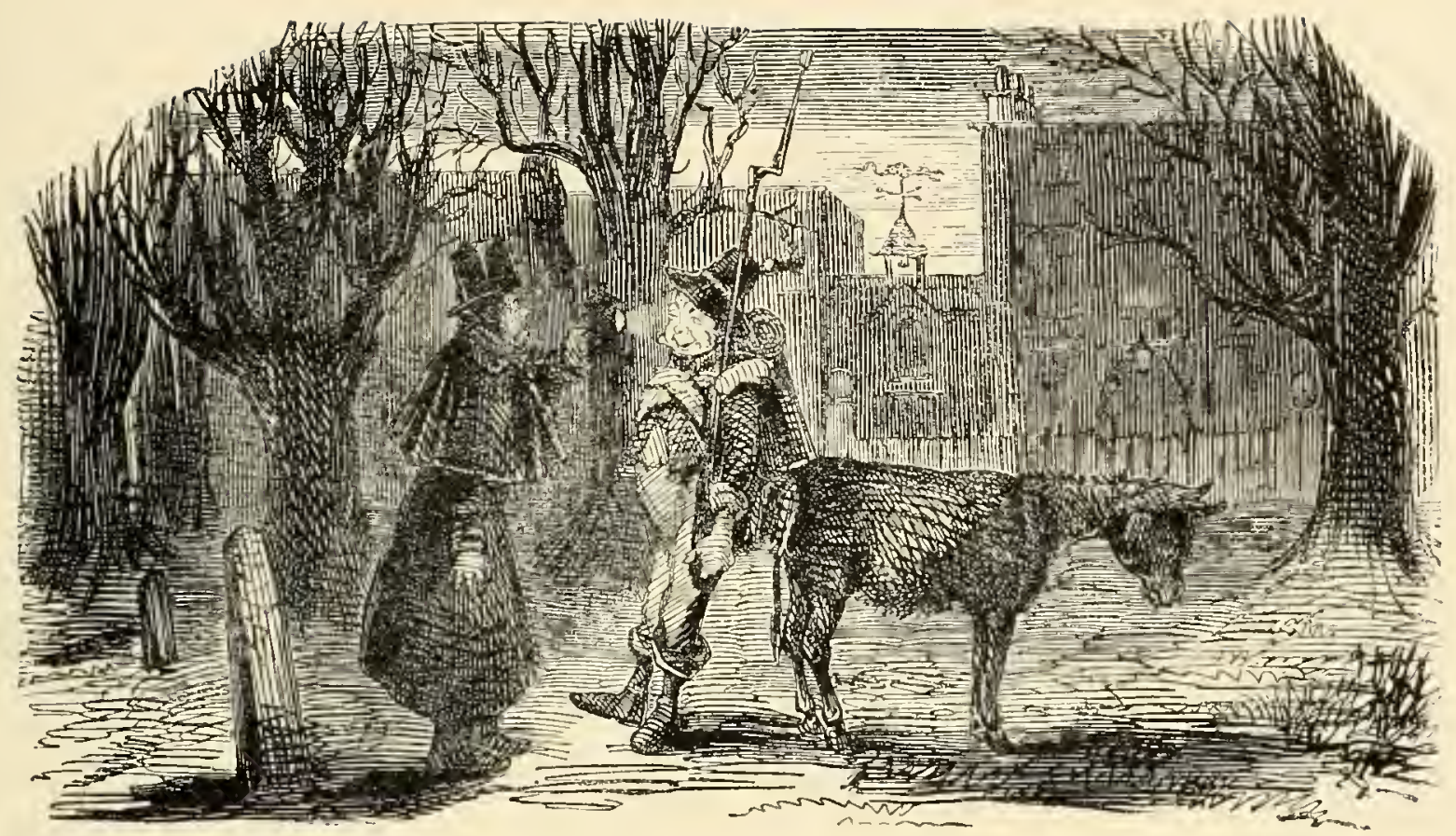

THE BROOK-GREEN VOLUNTEER.

Having cured his cold with rum-and-water, resolves not to go home " till day-light does appear." He assures the policeman that "It's all right." 


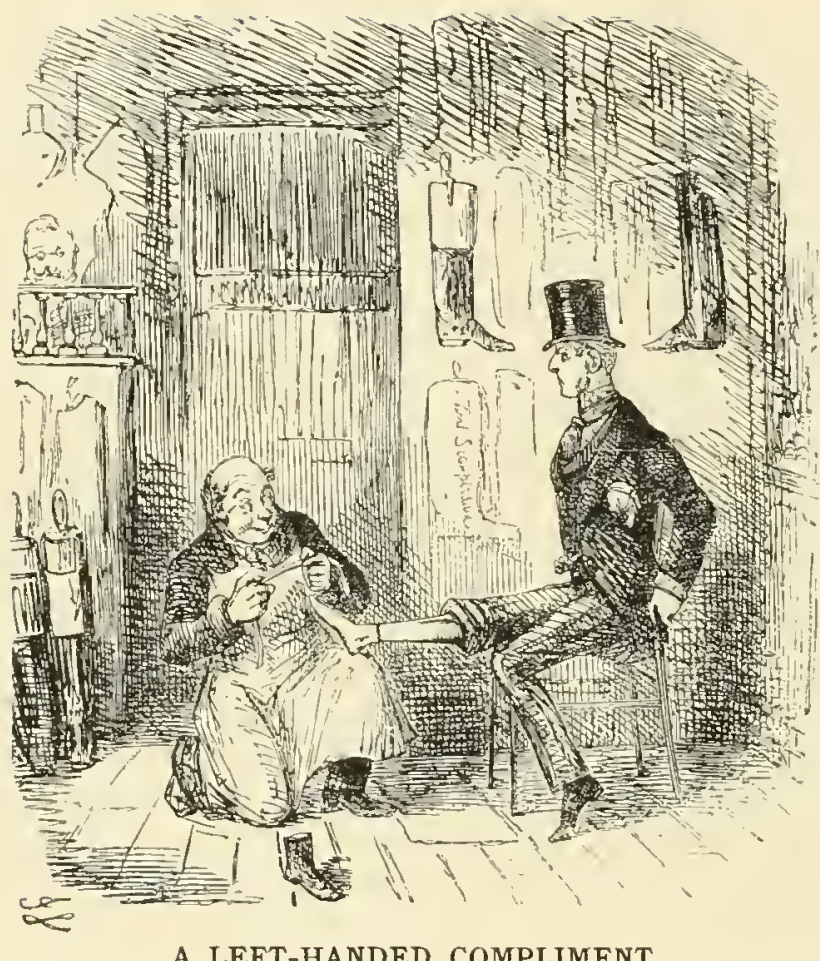

A LEFT-HANDED COMPLIMENT.

Bootmaker (with great fecling), "Oh no, Sir! don't have Napoleons; have tops, Sir!-yours is a beautiful leg for a top boot, Sir!-(yonng Nimrod is immensely pleased)beautiful leg, Sir! same size all the way down, Sir!"(young Nimrod is immensely disgusted). 


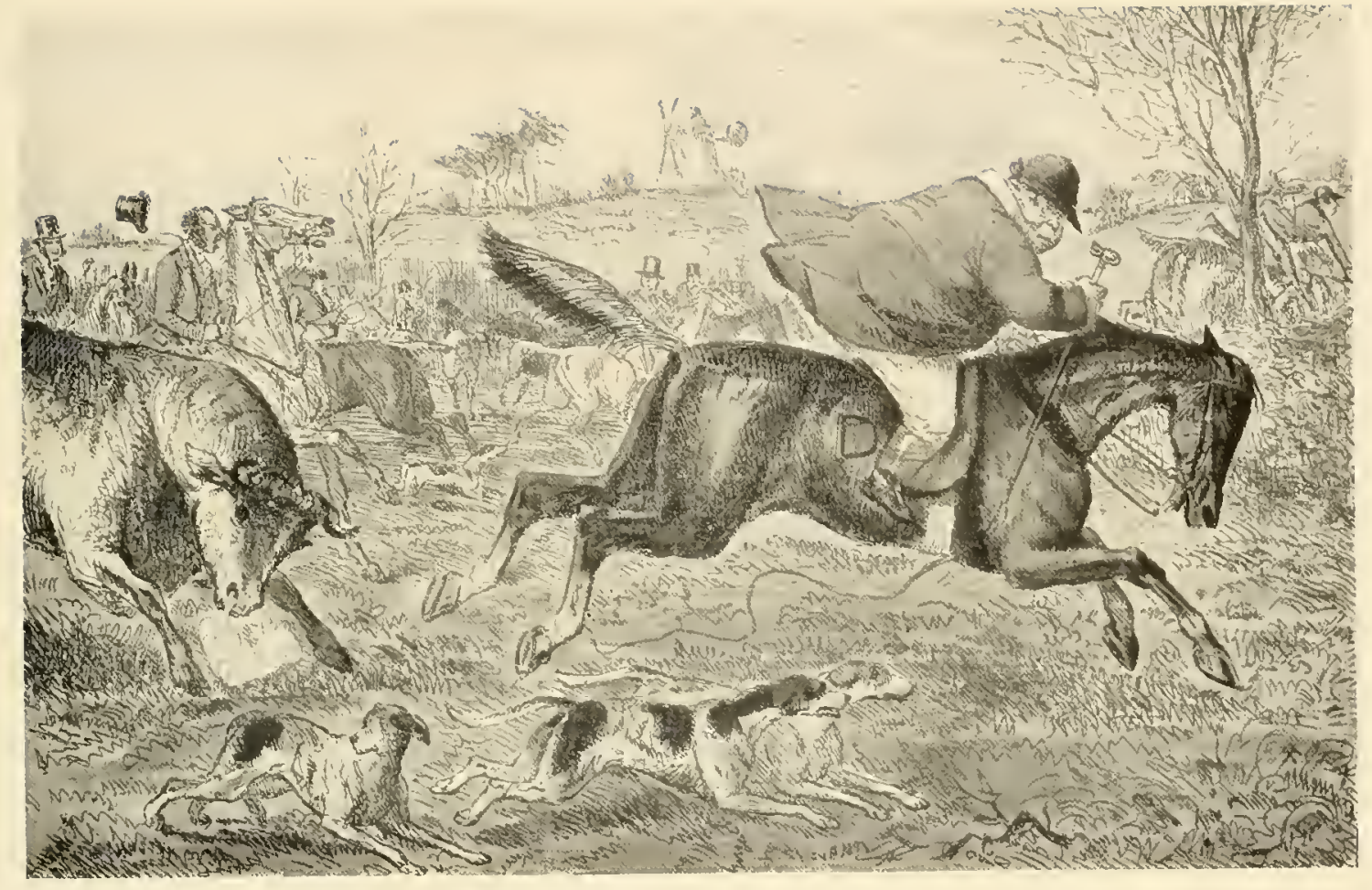

"Mind the Bull."-From "Handloy Cross." 


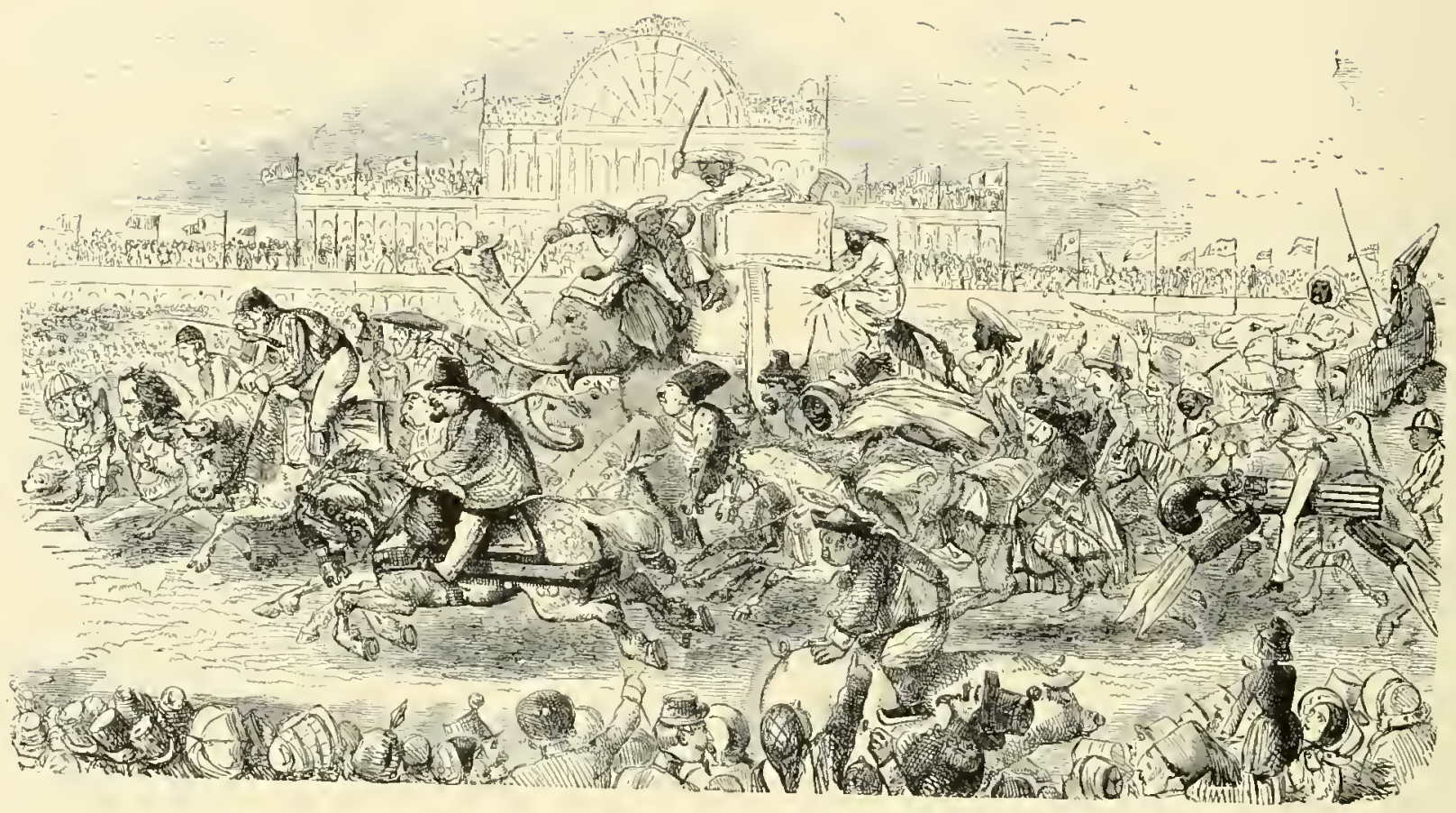

THE GREAT DERBY RACE FOR EIGHTEEN HUNDRED AND FIFTY-ONE. 


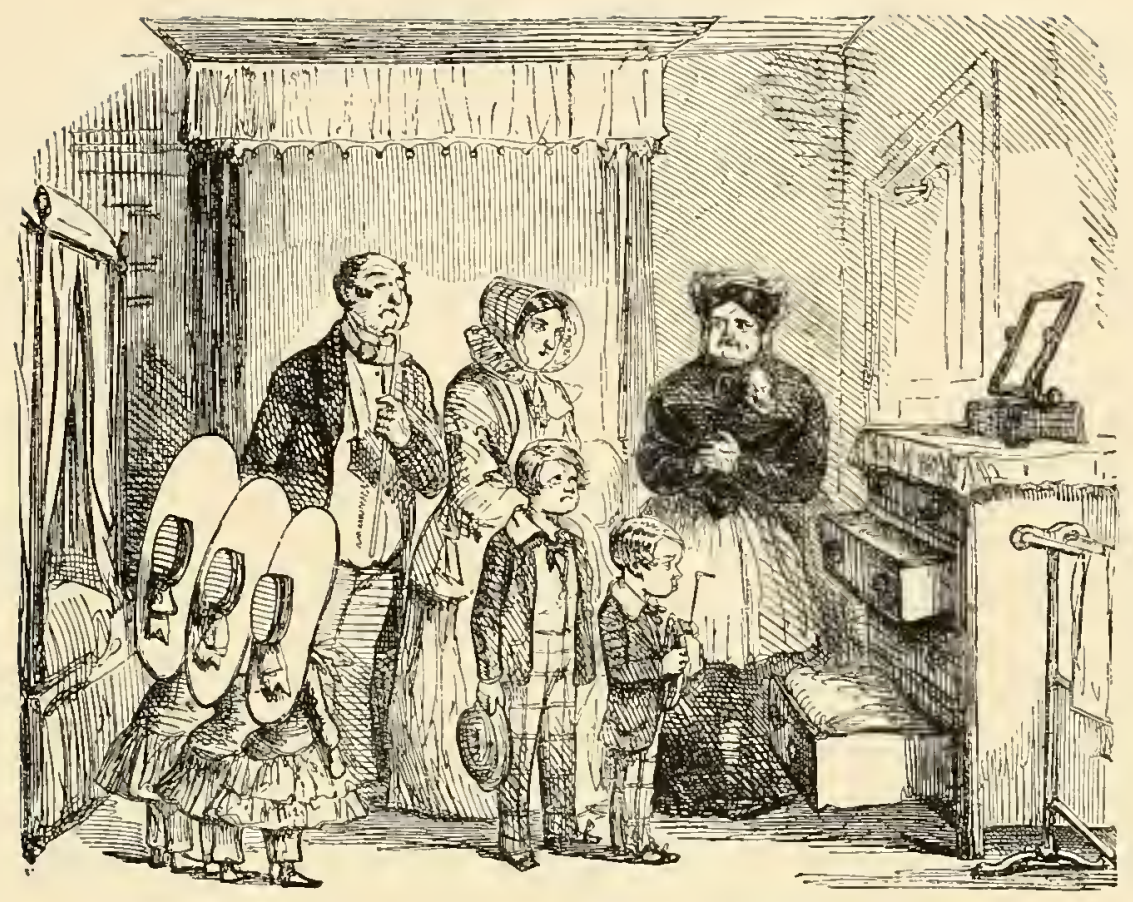

CROWDED STATE OF LODGING HOUSES.

Lodging-house Kceper. " "On'y this room to let, Mem. A four post-a tent -and a very comfortable double-bedded chest of drawers for the young gentlemen." 


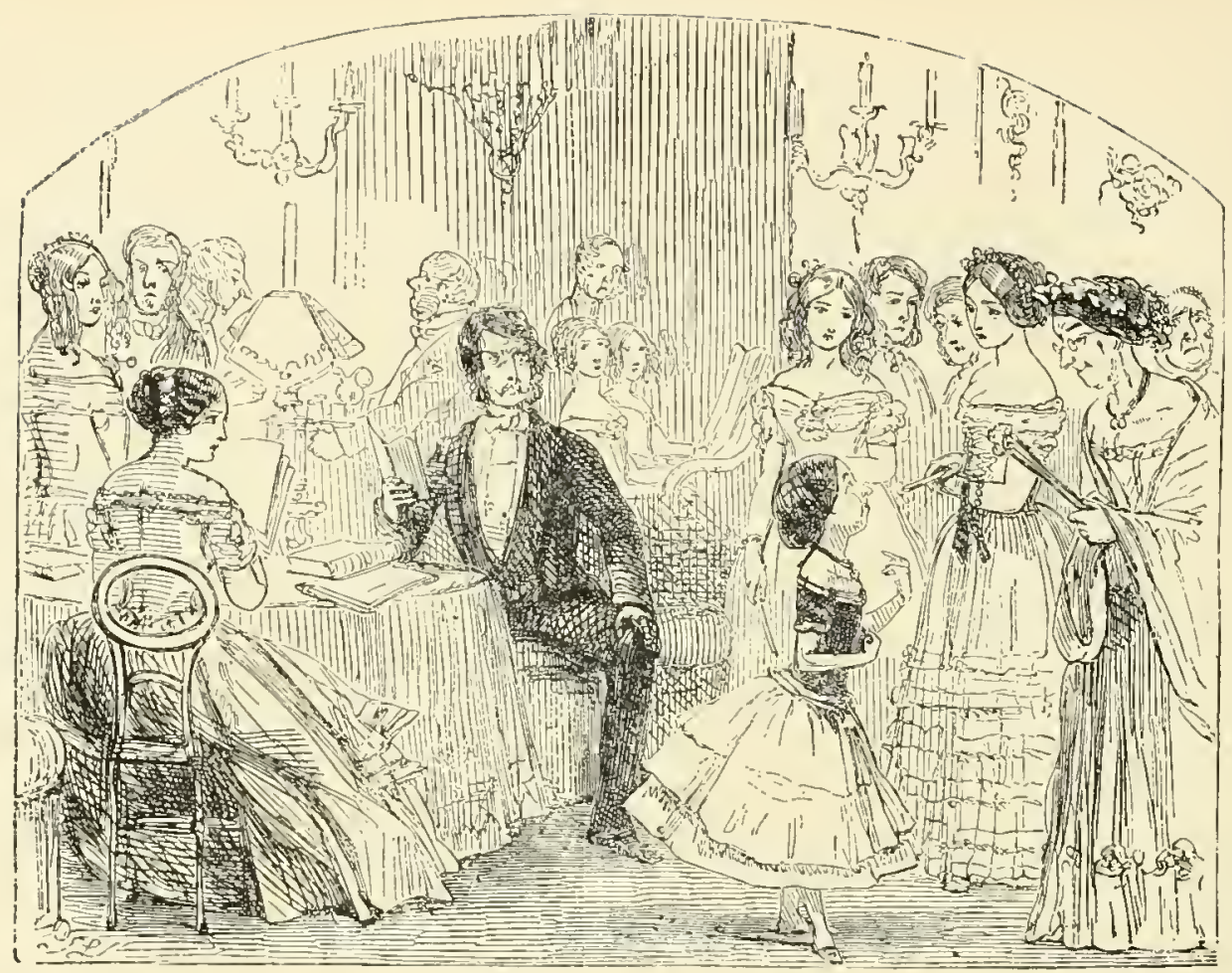

A PRODIGIOUS NUISANCE.

Learned (but otherwise highly objectionable) Child (loq.) "Oh, Mamma, dear! what do you think? I asked Mr. - and Miss — to name some of the remarkable events from the year 700 to the year 600 B.C., and they couldn't. But $I$ can-and-the second Messenian War commenced; and - the poet Tyrtæus flourished; Byzantium was founded by the inhabitants of Megara; Draco gave laws to Athens; Terpander of Lesbos, the musician and poet; Thales of Miletus, the philosopher; Alcæus and Sappho, the poets, flourished; and Nebuchadnez

(Sonsation from right and left, during which the voice of Child is happily dronuned.) 


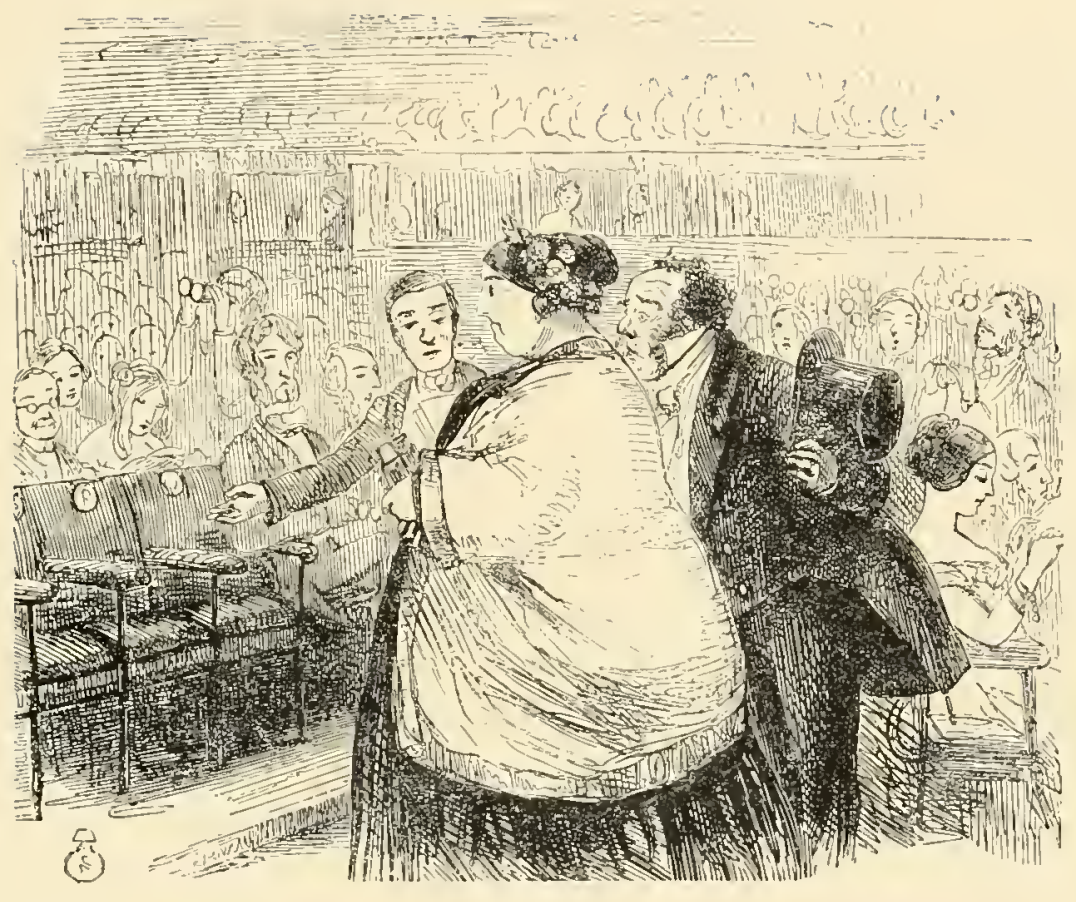

THE OPERA.

Box-Kecper. "Stalls 2 I 6 and I7, this way, Ma'am; last row, Ma'am. Won't you like a book, Ma'am?" 


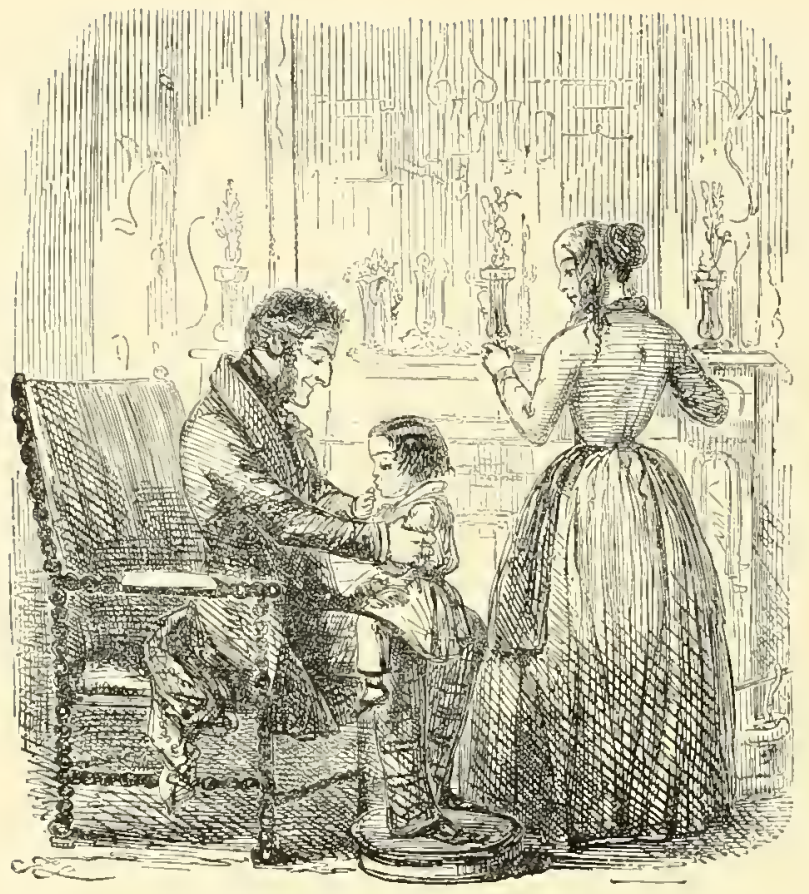

COMPARATIVE LOVE.

Papa. "So, Charley, you really are in love with the little black-eyed girl you met last night?"

Charley. "Yes, Papa, I love her dearly!"

Papa. "How much do you love her, Charley? Do you love her as much as pudding?"

Charlcy. "Oh yes, Papa! and a great deal better than pudding. But-(pausing to reflect) -I don't love-her so much as - jelly!" 


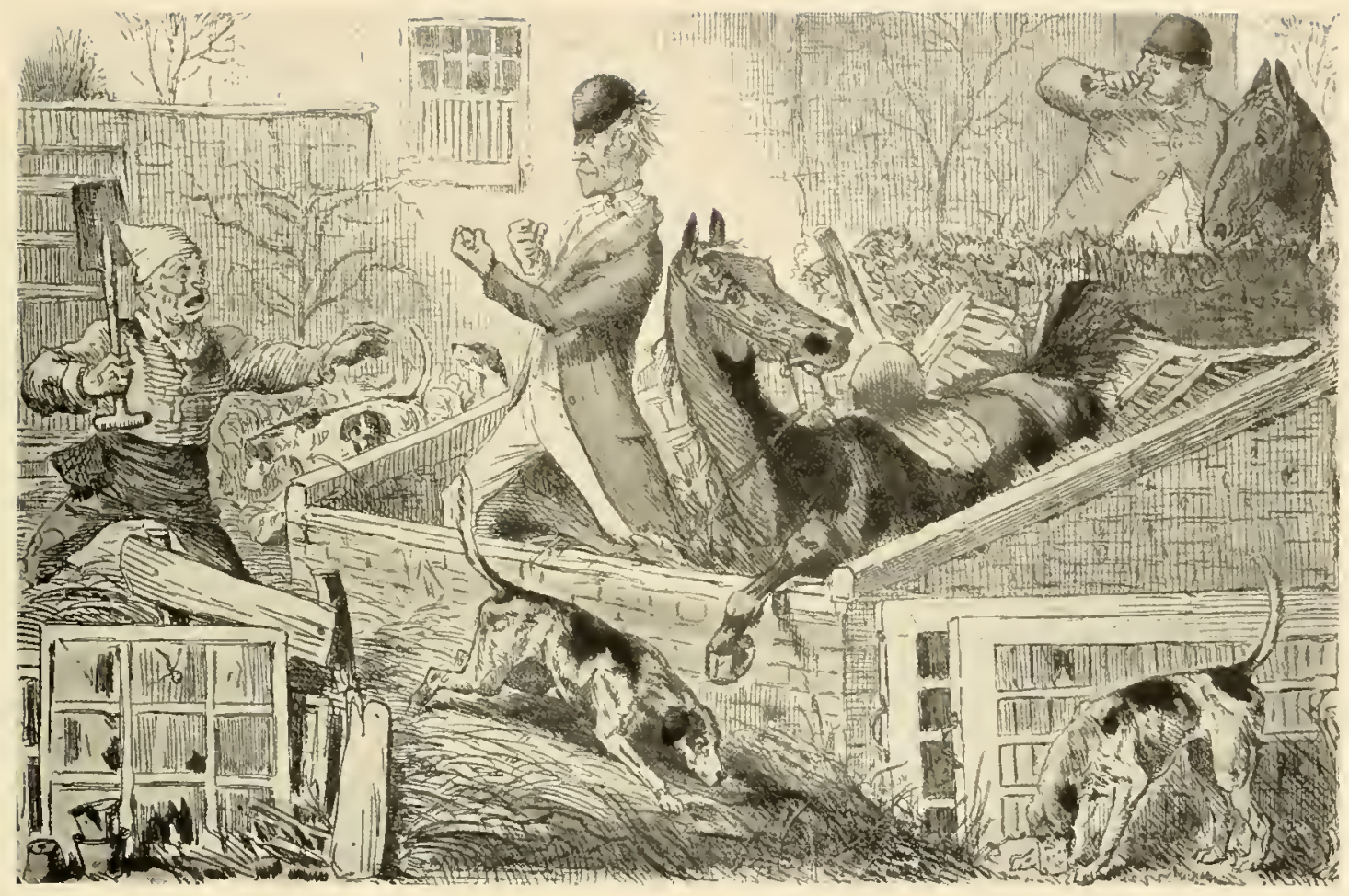

Pigg in the Melon Frame.-From "Handley Cross." 


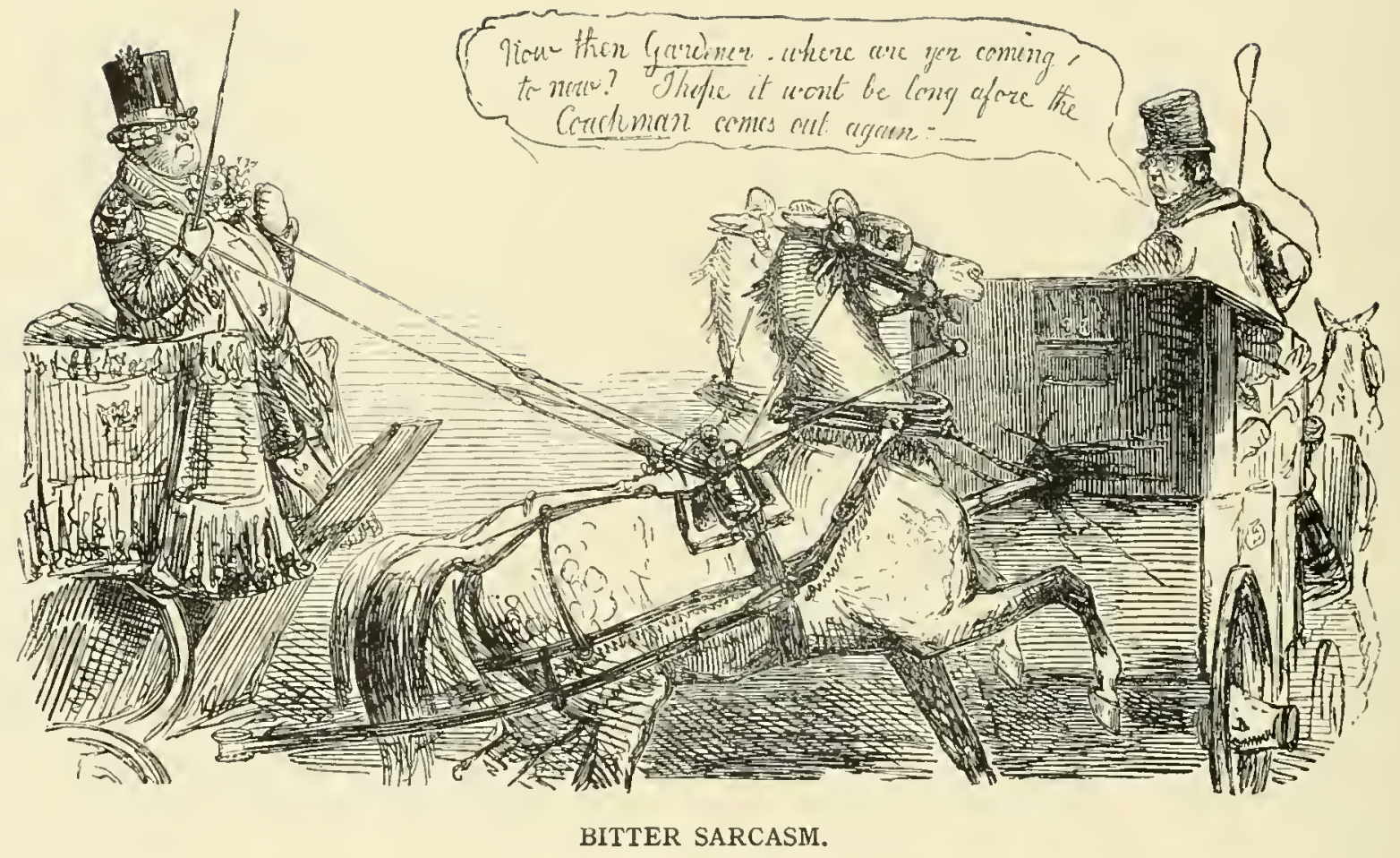




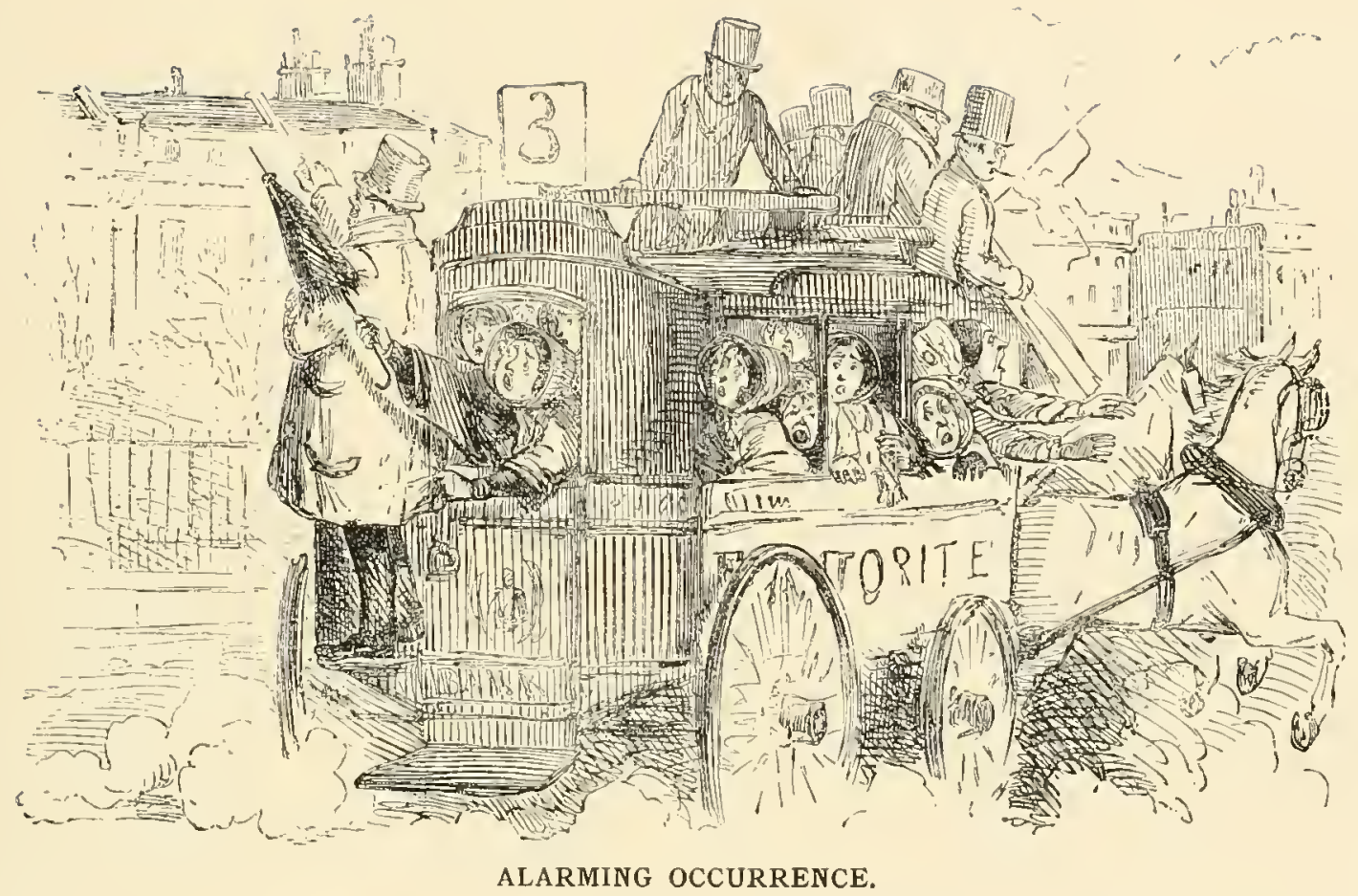

Chorus of Unproticted Females. "Conductor! Stop! Conductor! Omnibus-man! Here's a gentleman had an accident and broke a jar of leeches, and they're all over the omnibus!" 


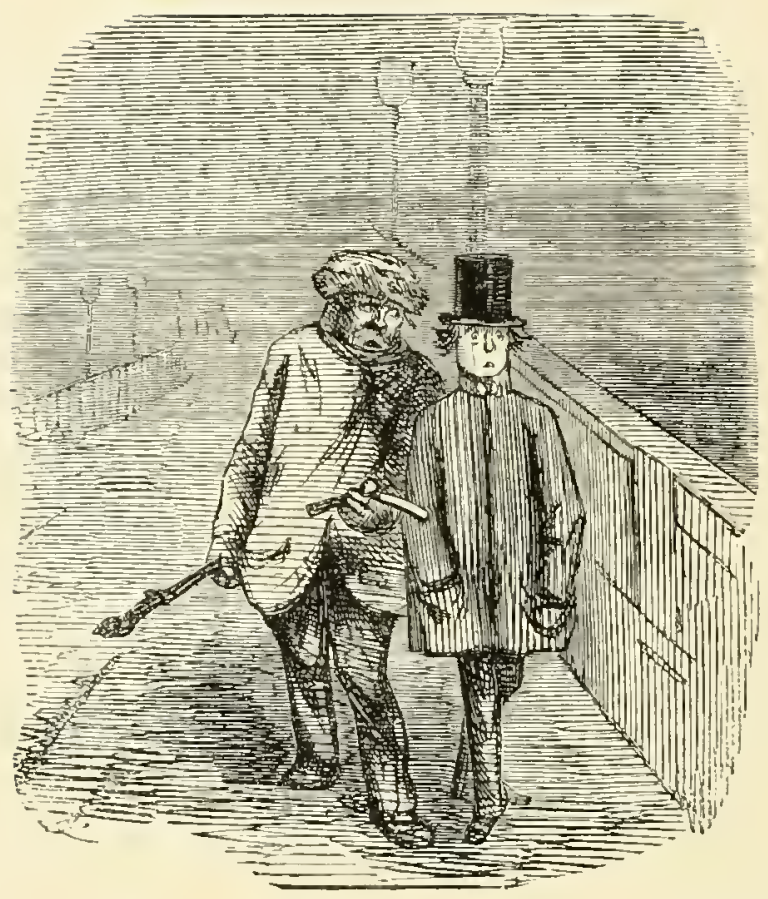

SCENE, WESTMINSTER BRIDGE.-TIME, TWO ON A FOGGY MORNING.

Reduced Tradesman (to a little party returning home). "Did you want to buy a good razor?" 


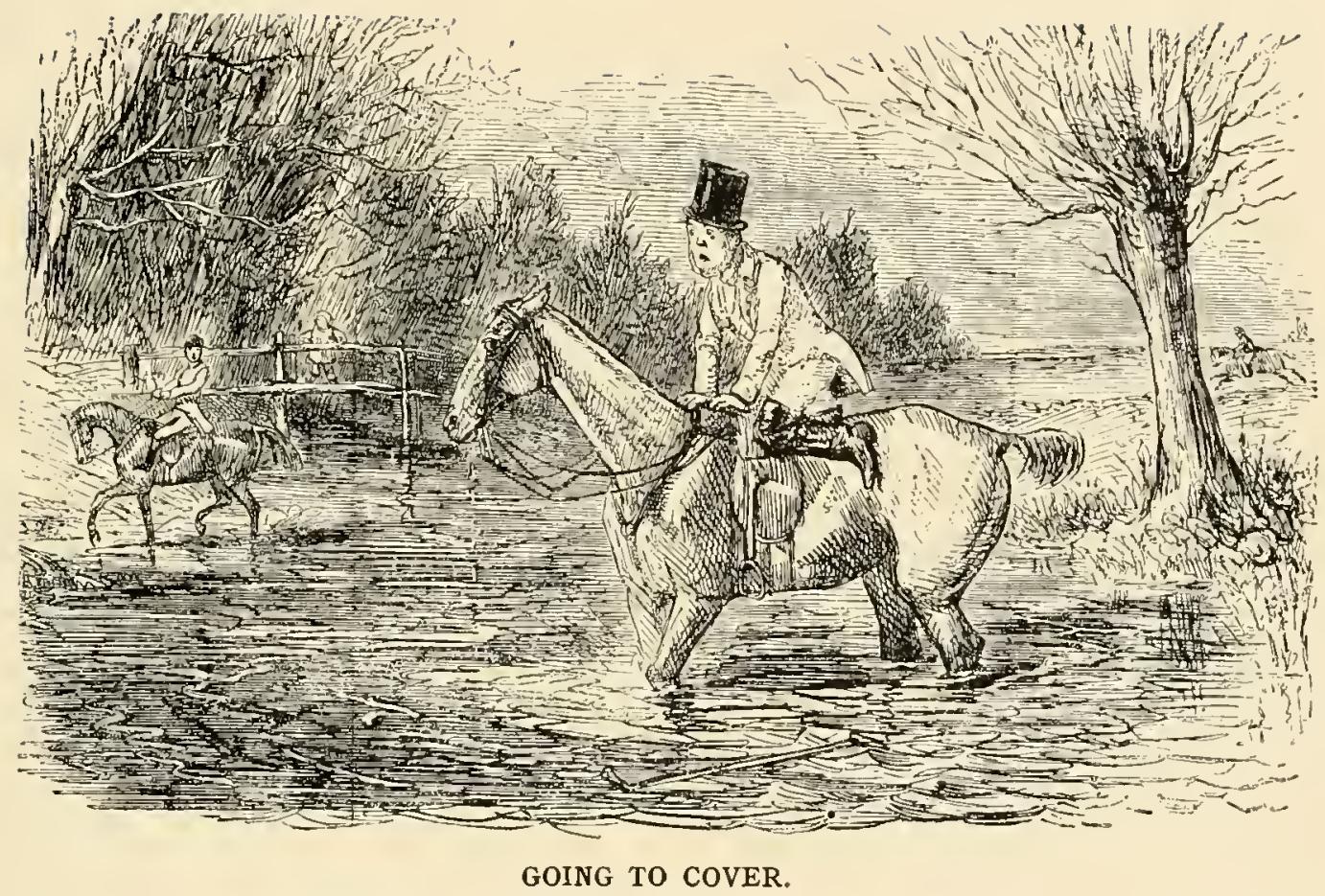

Voice in the distance. "Now, then, Smith-come along!"

Smith. "Oh, it's all very well to say, come along! When he won't move a step; and I'm afraid he's going to lie down." 


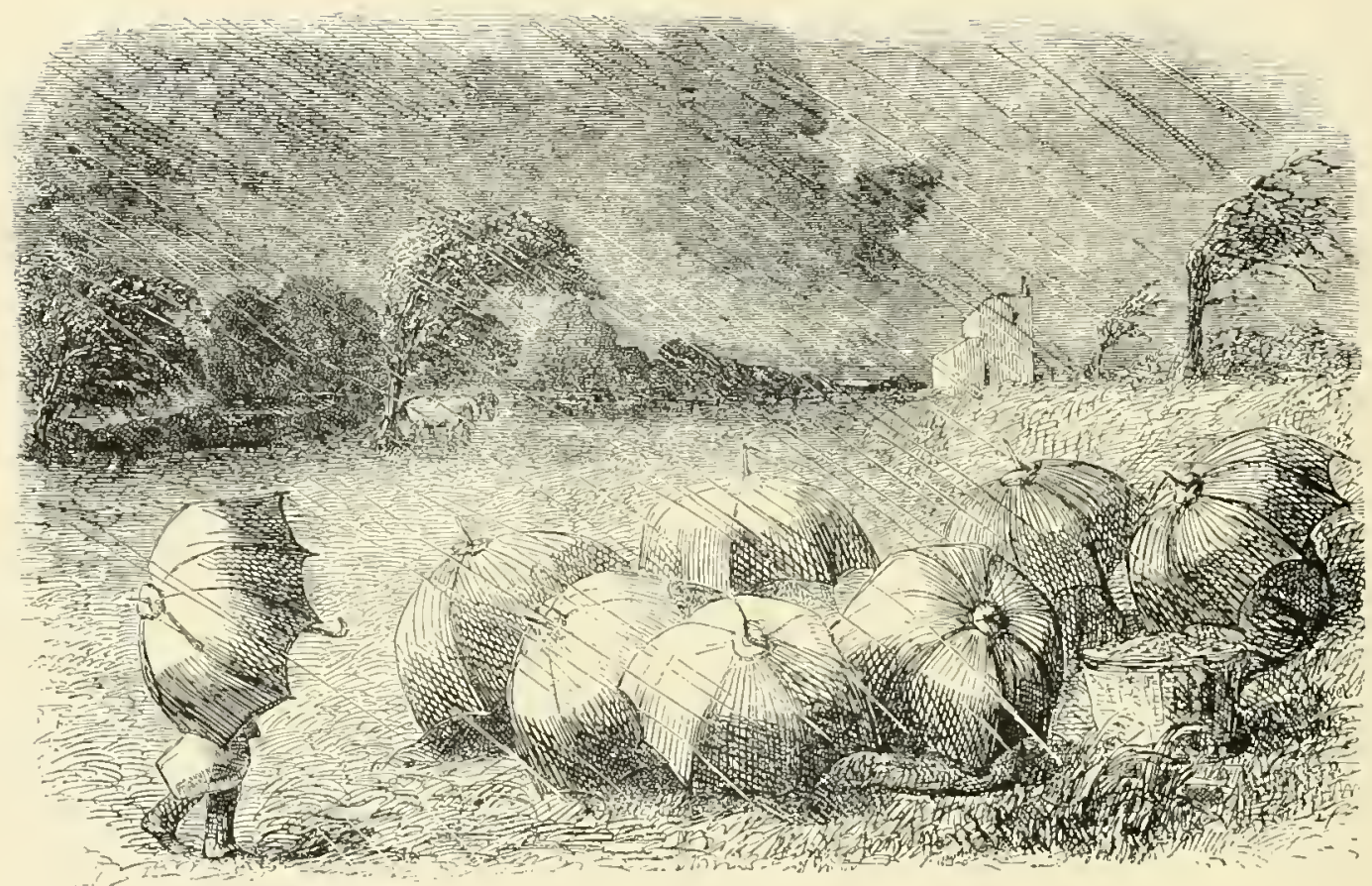

THE PIC-NIC.

Contcnted Man (loq.) "What a nice damp place we have secured; and how very fortunate we are in the weather; it would have been so provoking for us all to have brought our umbrellas and then to have had a fine day! ! Glass of wine, Briggs, eh?" 


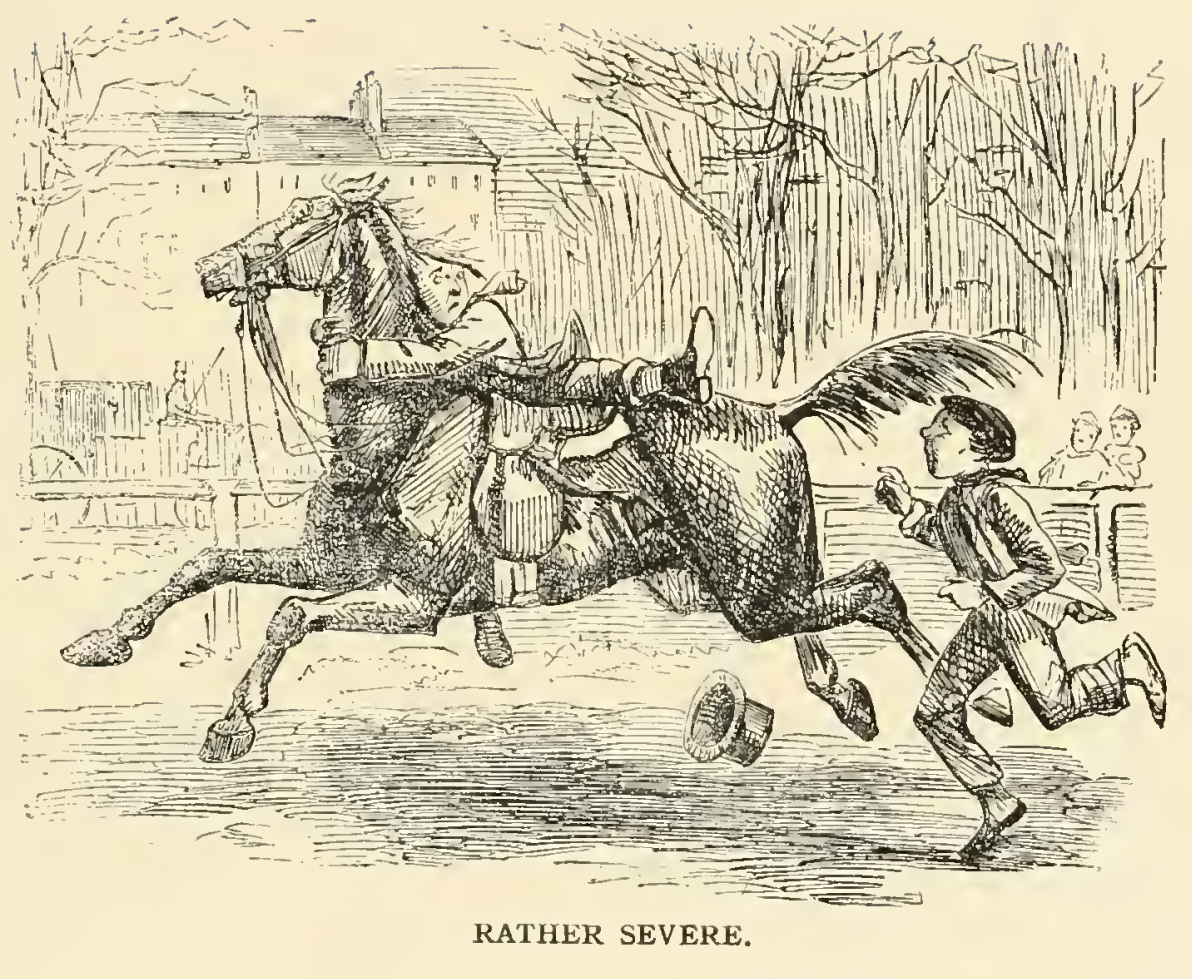

"Shall I 'old your 'orse, Sir?" 


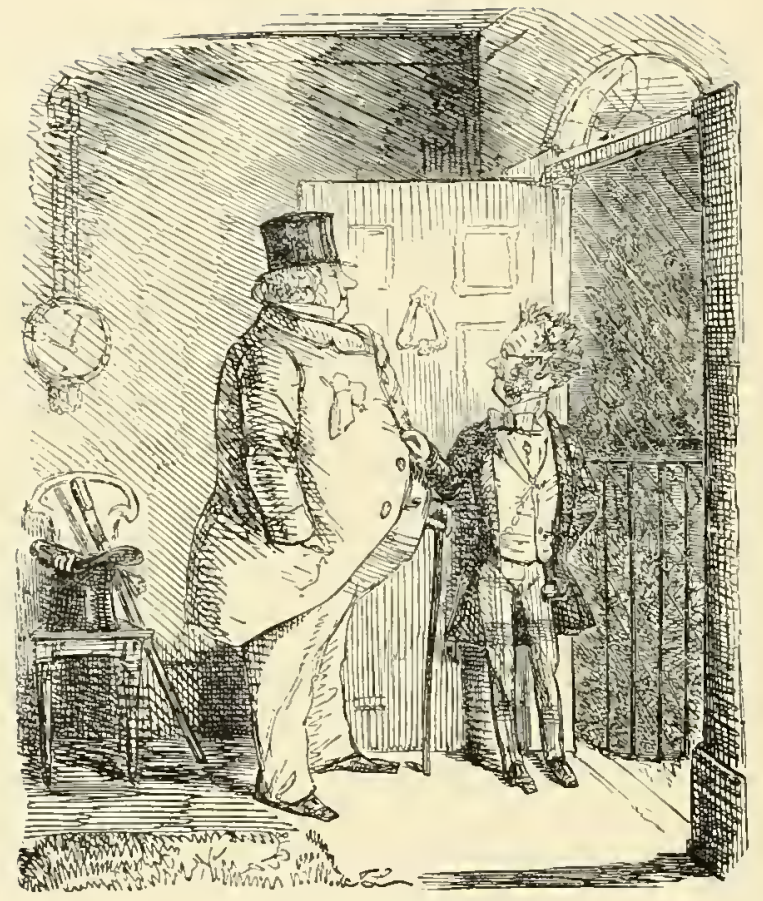

VERY CONSIDERATE.

Affable Little Gentleman. "Dear, oh dear! how it rains! I'm afraid you'll get very wet-can I offer you a great coat or anything ?" 


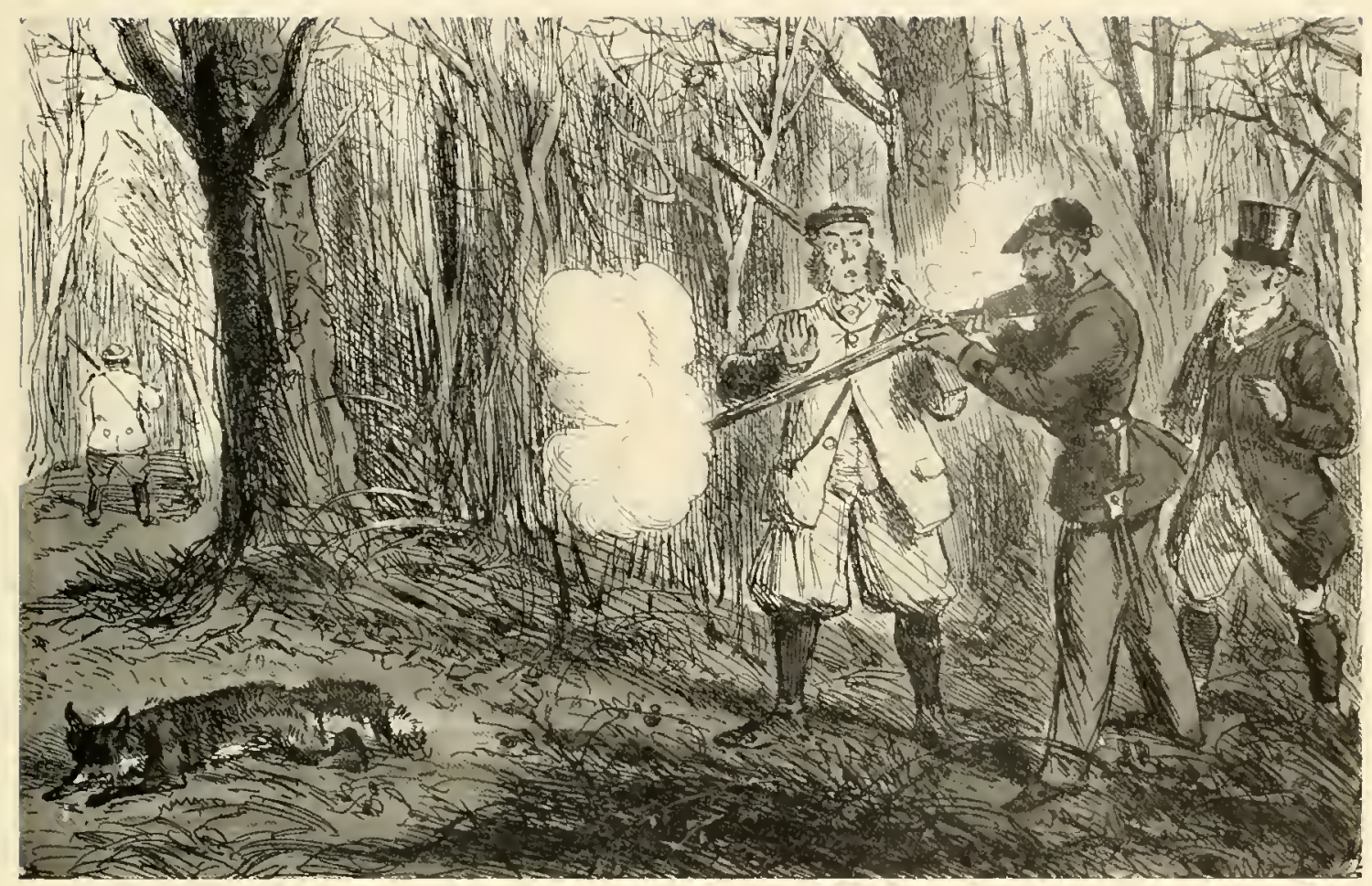

The Foreign Prince distinguishes himself.-From " Plain or Ringlets." 


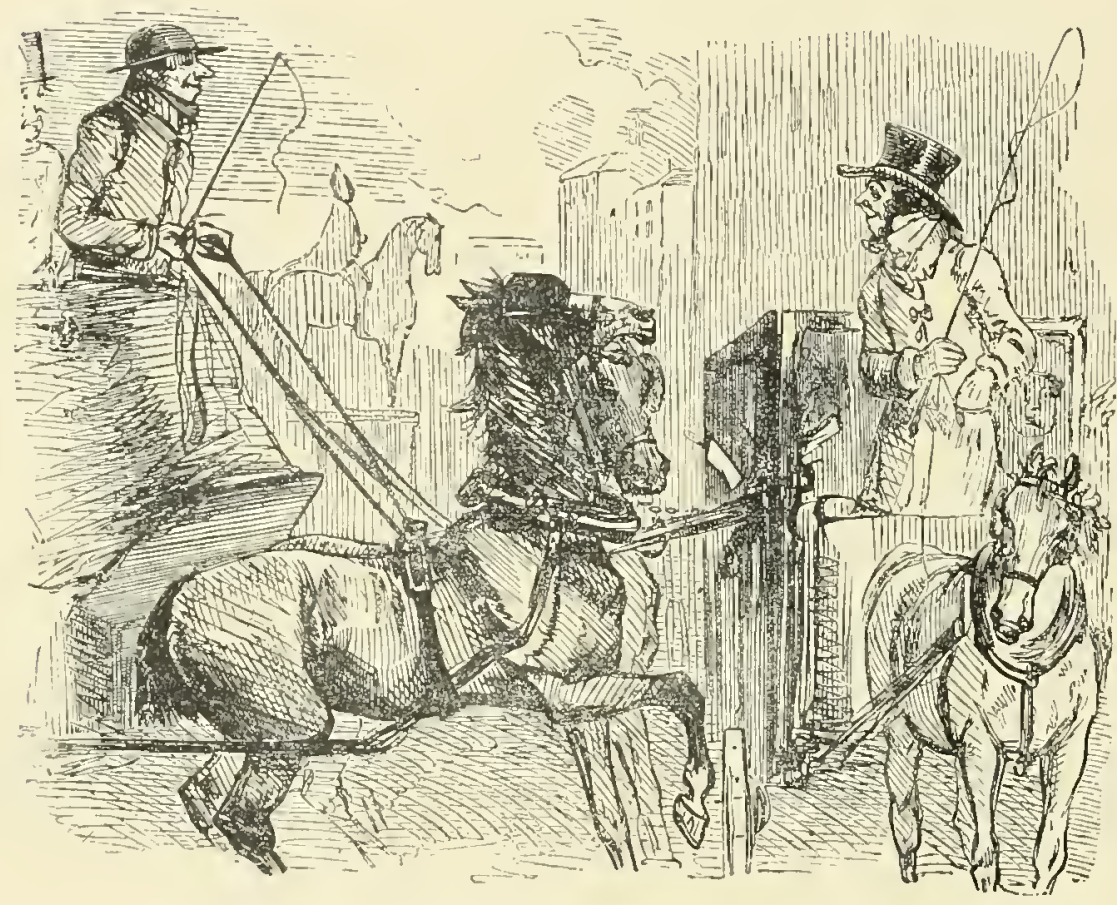

MANNERS MAKE THE MAN.

Omibus Driver, "I beg you a thousand pardons, I am sure."

Cabman. "Oh, pray don't mention it. It's of no consequence, believe me!" 


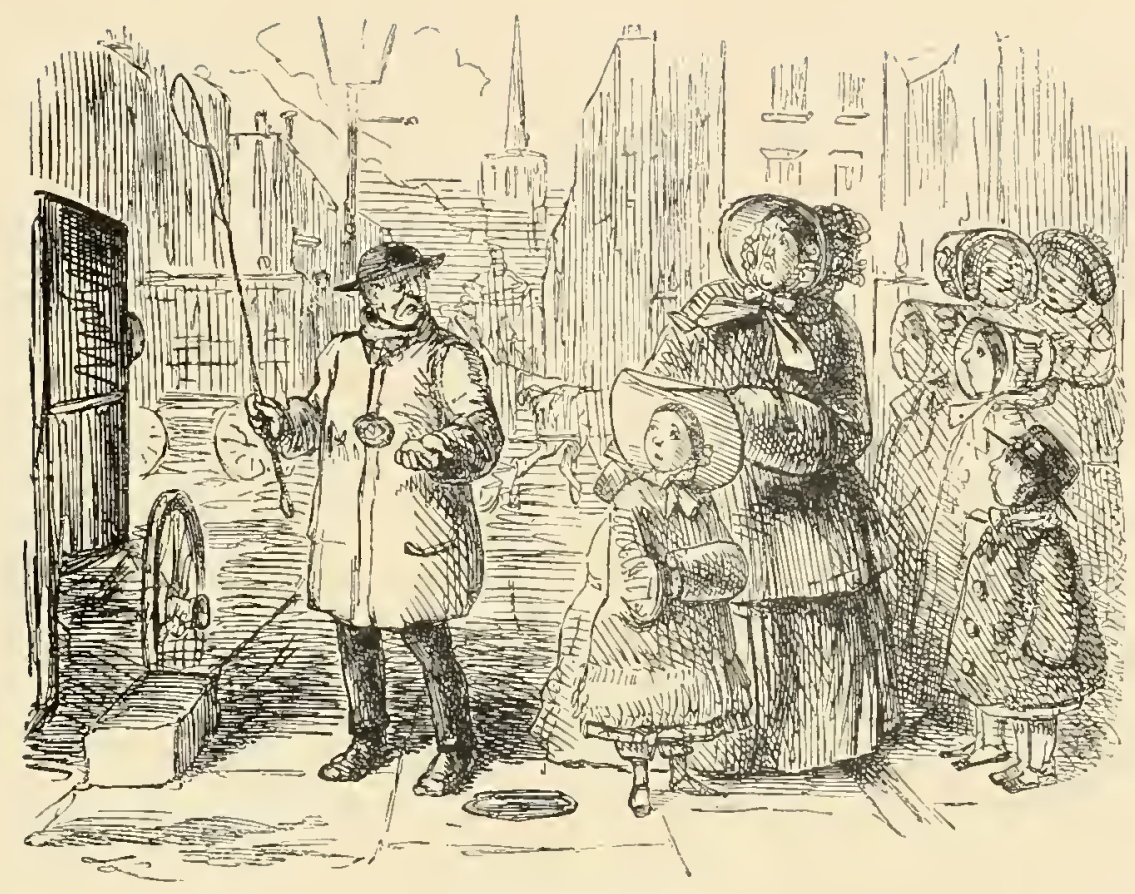

A BRITISH RUFFIAN.

Lady. "If you are not satisfied with what I have given you, there's a gentleman here who will settle with you."

Cabman. "No, there ain't! there ain't no gentlonan here!"

Lady. "I tell you there is. There is a gentleman in this house."

Cabman. "Oh, no, there ain't, not if he belongs to youl" 


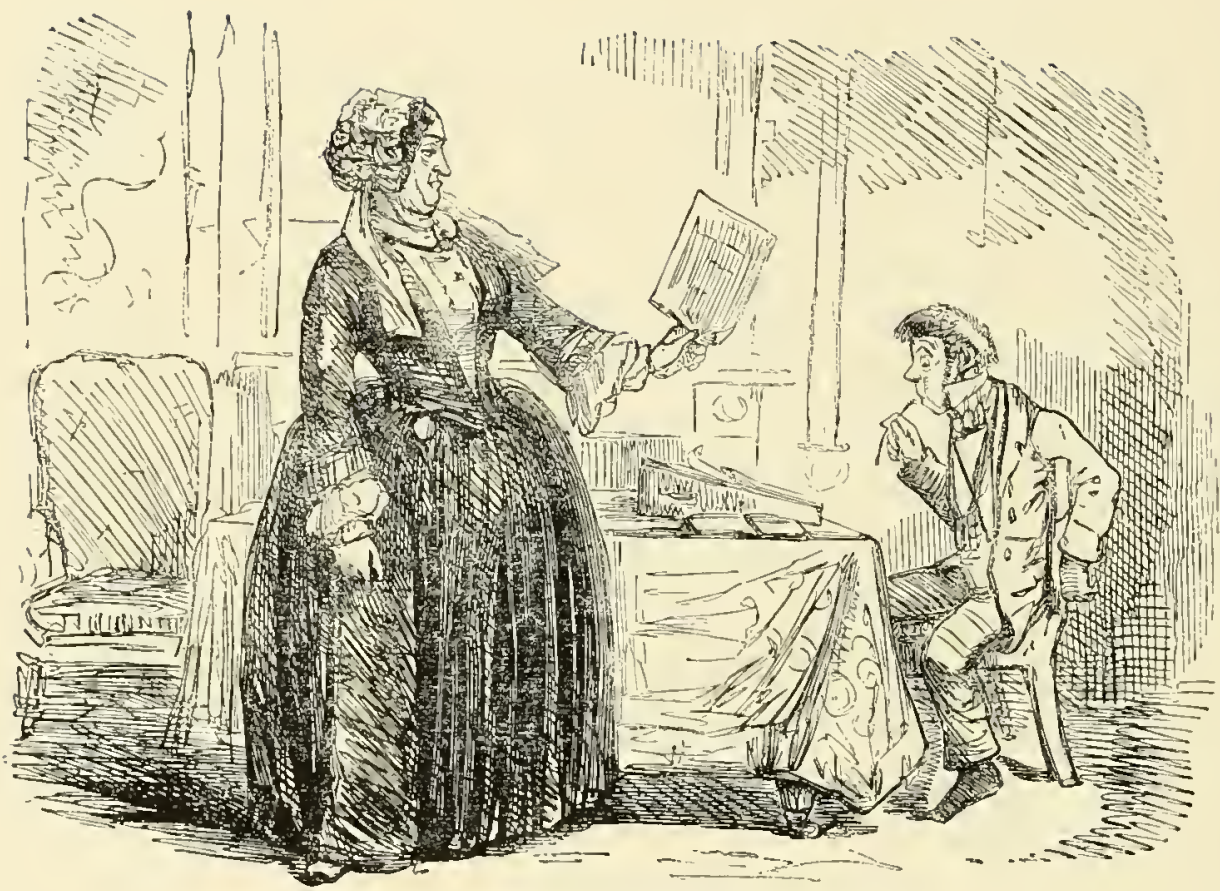

FILLING UP THE CENSUS PAPER.

Wife of his bosom. "Upon my word, Mr. Peewitt! Is this the way you fill up your census? So you call yourself the "head of the family'-do you-and me a femalel" 


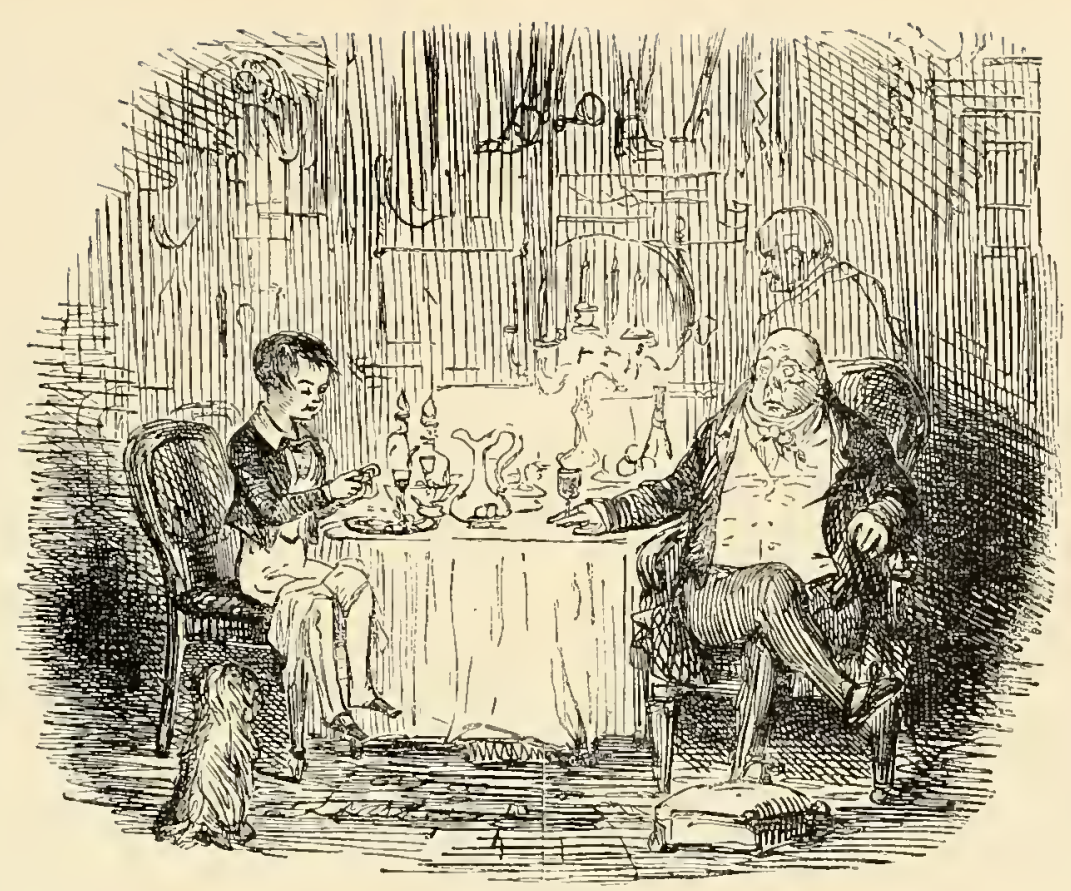

THE RISING GENERATION.

Old Gentlcman. “Well, Walter, I suppose you have got into Latin and Greek at school by this time, eh?"

Juvenile. "Oh, yes, Sir, I have just finished Xenophon and Thucidides, and am now in Euripides. By the way, Sir, how would you render the

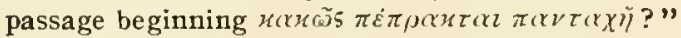

Old Gcntlcman. "Ahem! Hey?-What?-Ahem! here, Ruggles, bring another bottle of claret, and-.-eh? what? Walter, I think you had better join the ladies." 


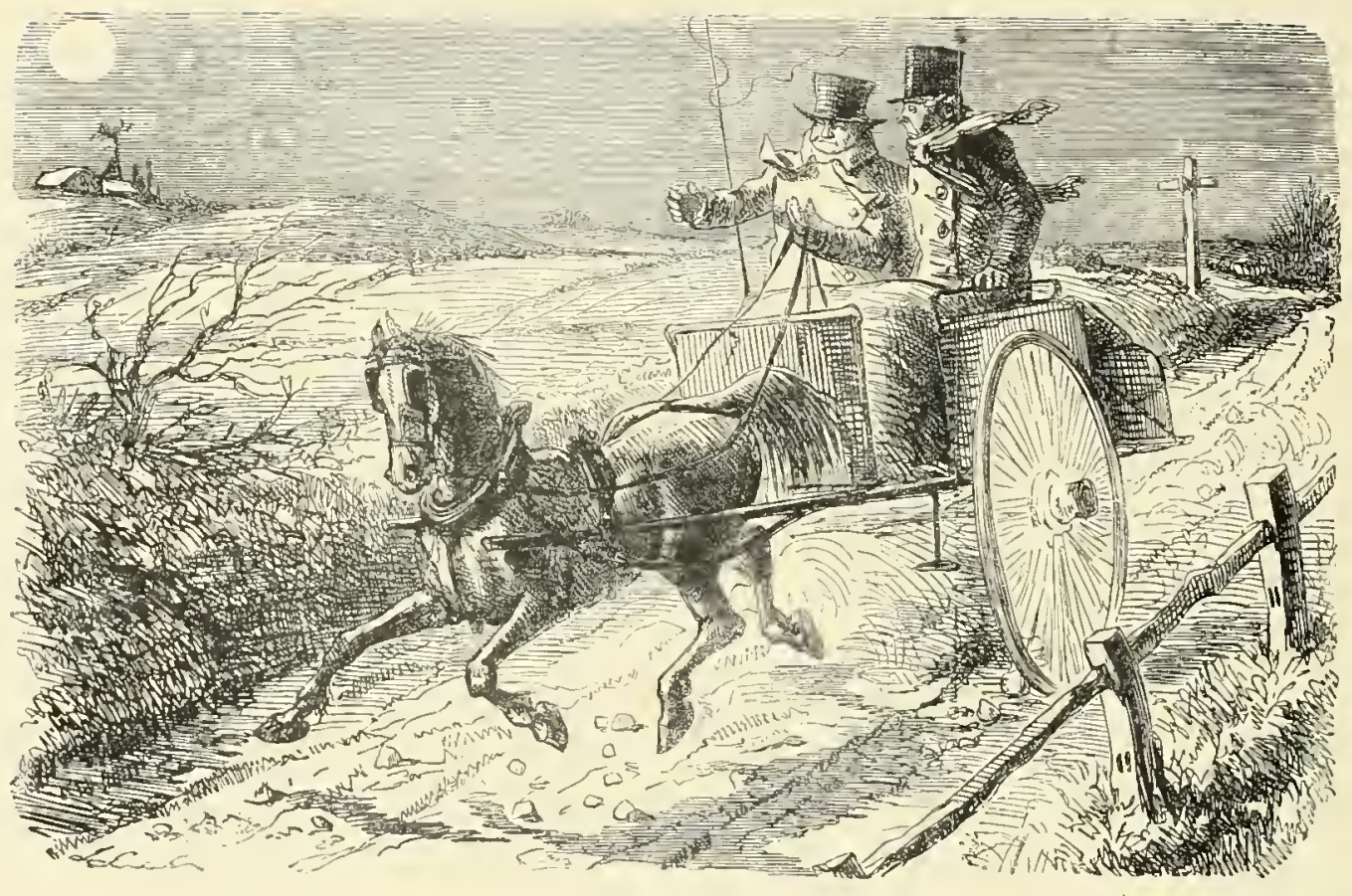

\section{PLEASANT!}

Nermons Gentleman. "Don't you think, Robert, going so fast down hill is very likely to make the horse fall?"

Robert. "Lor bless yer-no Sir! I never throwed a oss down in my life, 'xcept once, and that was one frosty moonlight night (just such a night as this it was), as I was a-drivin' a gent (as might be you) from the station, when I throwed down this werry oss in this werry identical place." 


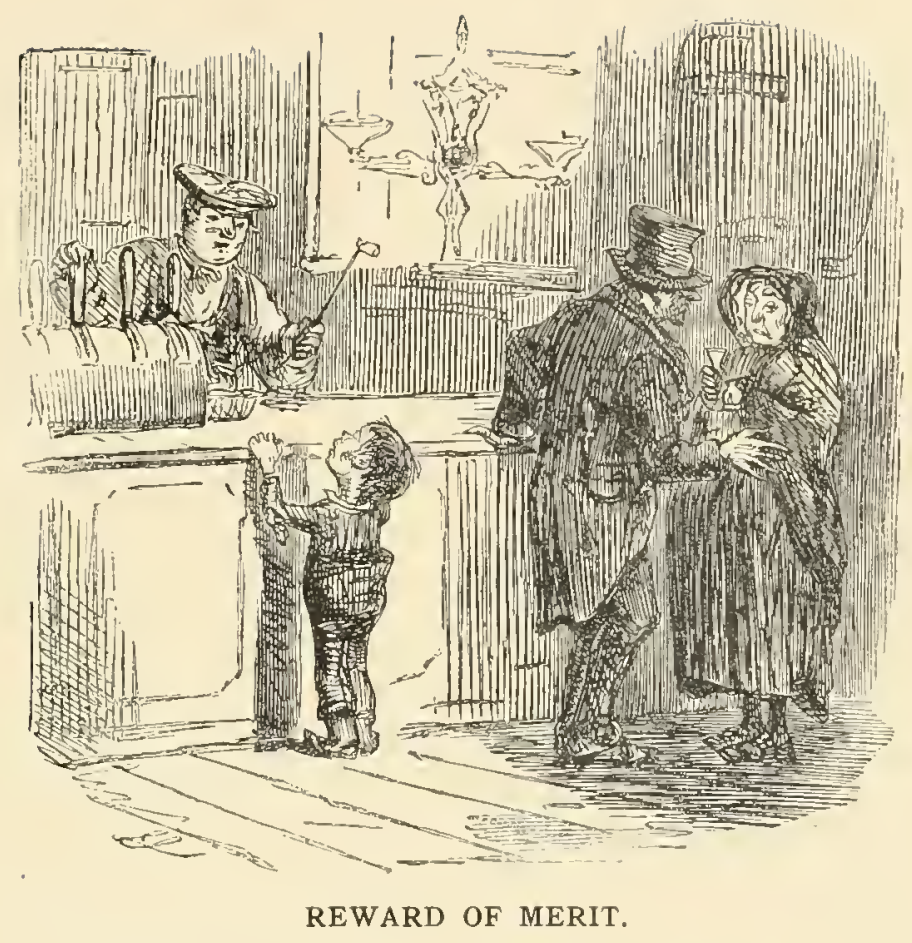

Ragged L'rchin. "Please, give Dad a short pipe."

Barman. "Can't do it. Don't know him."

Ragged Crchin. "Why, he gets drunk here every Saturday night."

Barman. "Oh! does he, my little dear? Then 'ere's a nice long 'un, with a bit of wax at the end." 


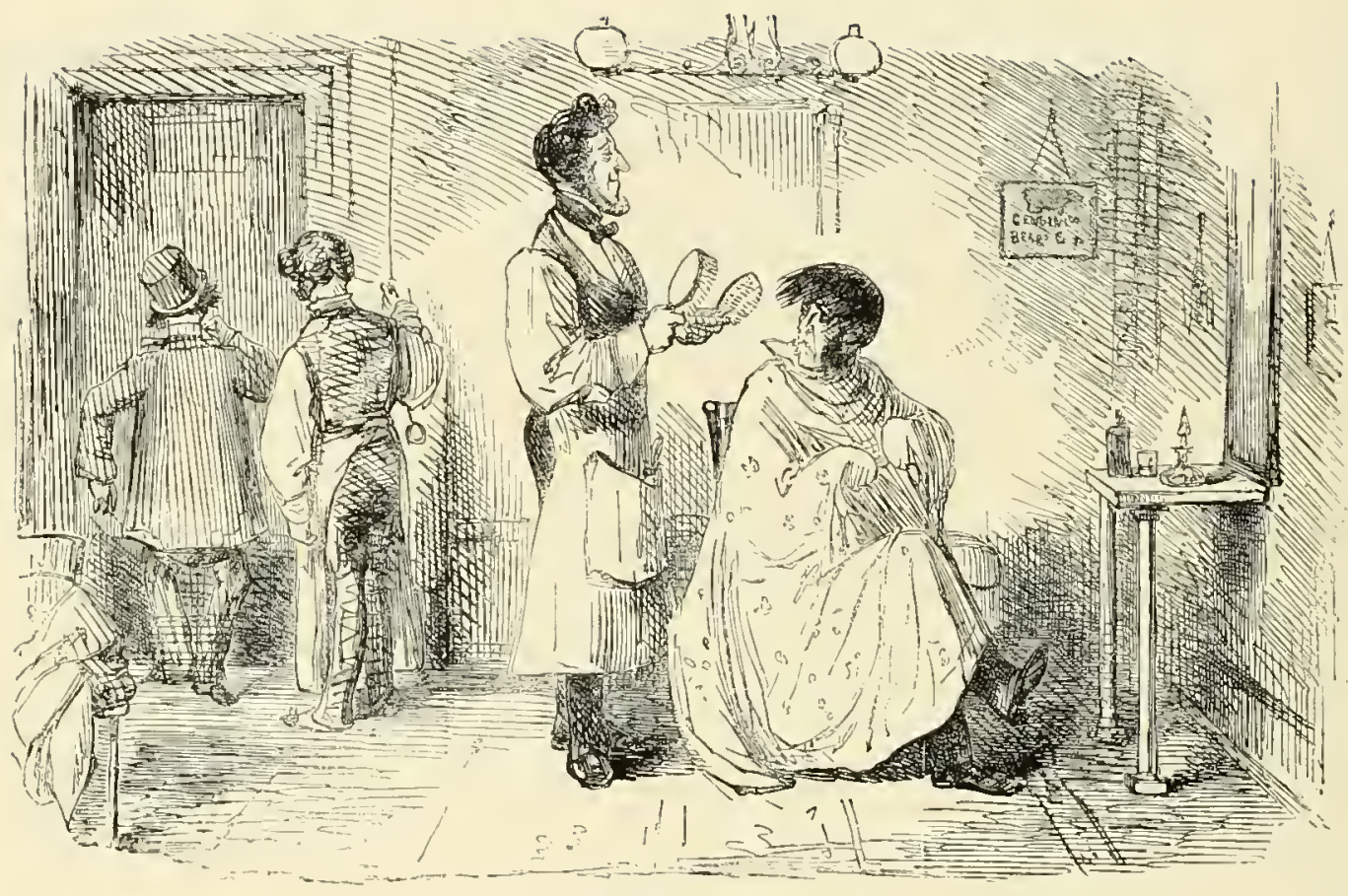

\section{ALARMING.}

Hairdresscr. "They say, Sir, the cholera's in the hair, Sir!"

Gent., very uncasy. " Indeed! Ahem! Then I hope you are very particular about the brushes you use."

Hairdresser. "Oh! I see you don't hunderstand me, Sir. I don't mean the 'air of the 'ed, but the hair $h$ cf the hatmosphere?" 


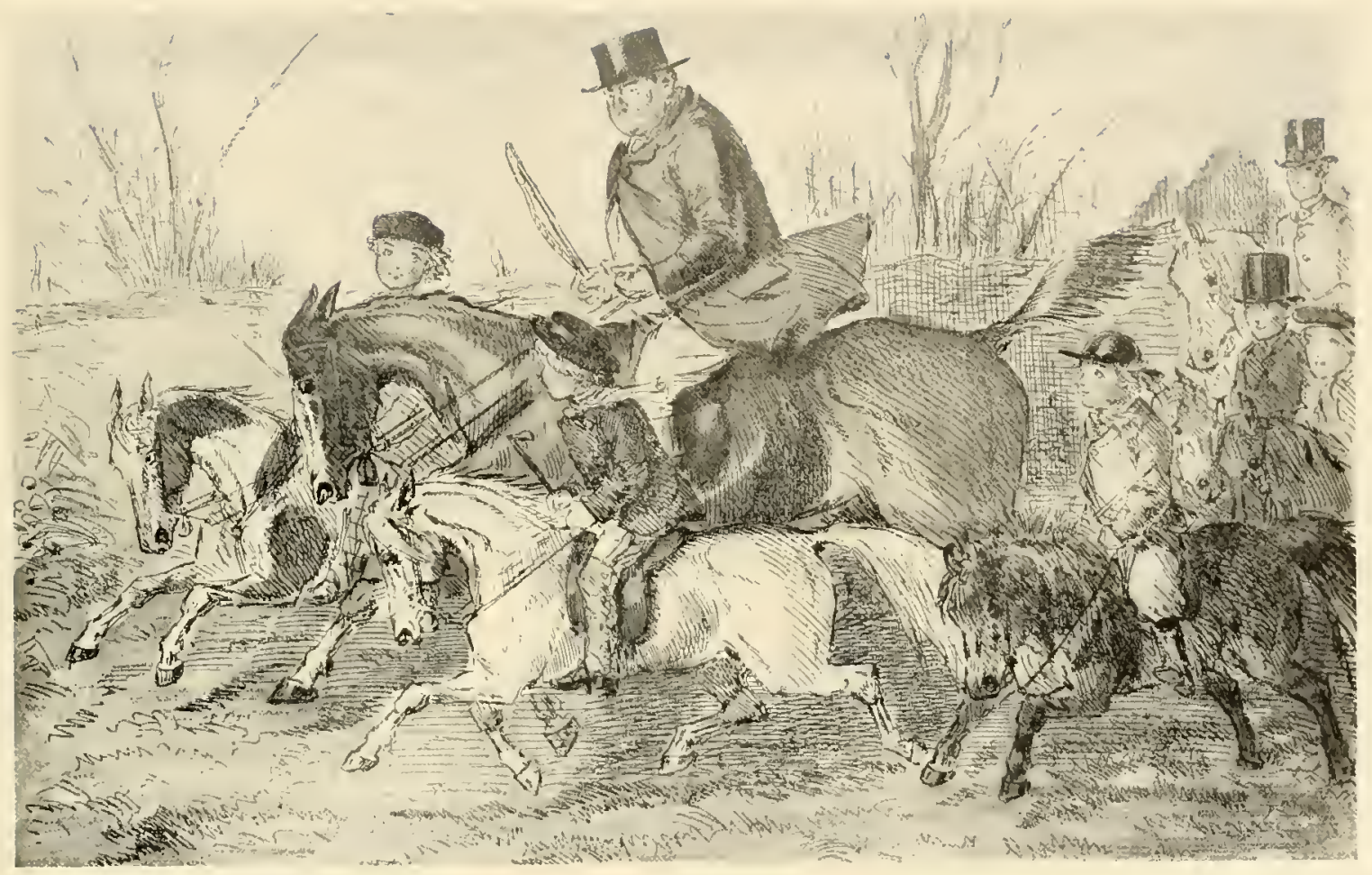

The Jug and his Juvenile Field.-From "Plain or Ringlets." 


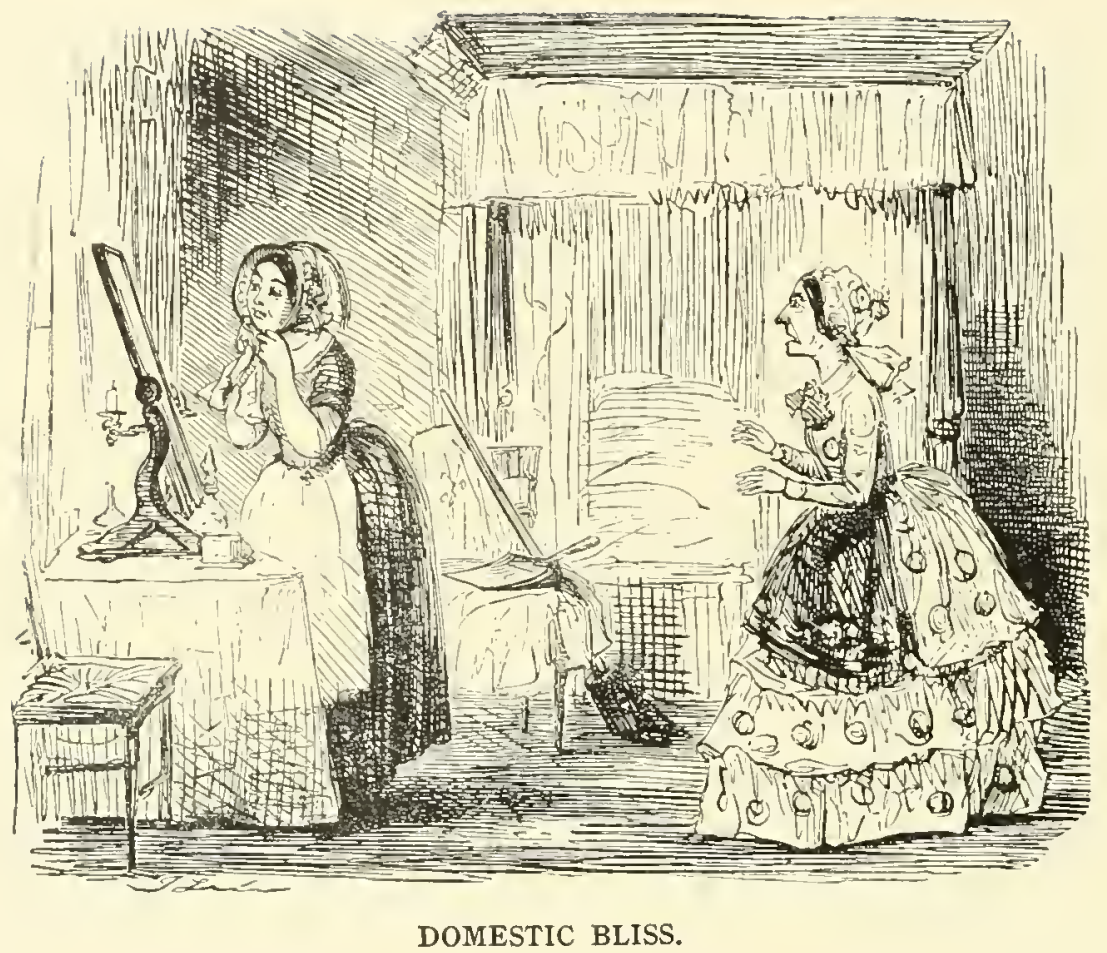

Domestic (soliloquising). "Well! I'm sure Missus had better give this new bonnet to me, instead of sticking such a young-looking thing upon her old shoulders." (The impudent minx has immediate warming.) 


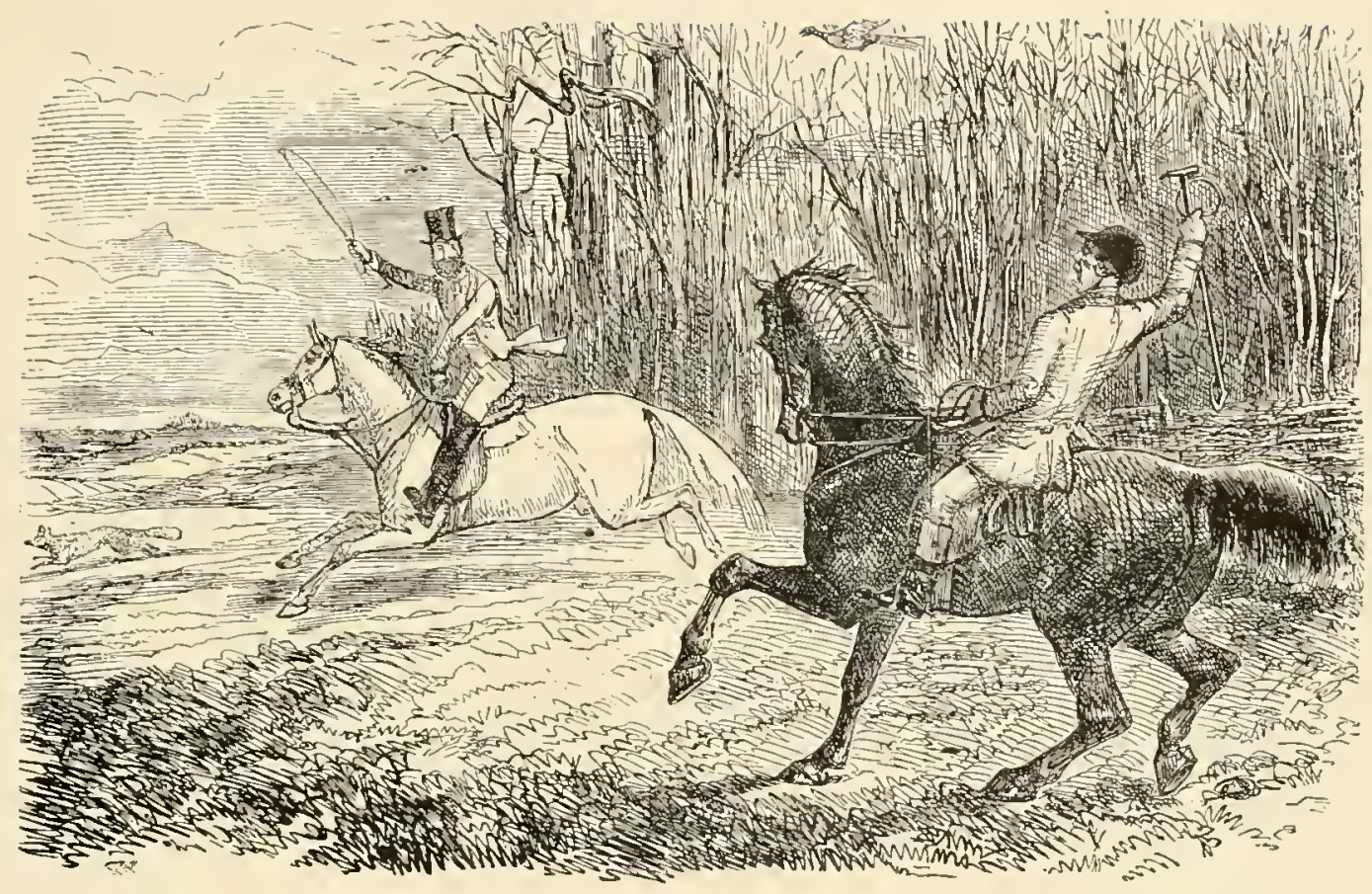

FOX STEALS AWAY FROM THE COVER; BEARDED FOREIGNER OF DISTINCTION IMMEDIATELY GIVES CHASE.

IVhipper-in (with cxcitemcnt, loquitur). "'Old 'ard, there! 'old 'ard! where are you a-galloping to? Do you think you can catch a fox?" trai!"

Forcigner of Distinction (with greut glec).

"I do not know, mon ami; but I will trai-I will 


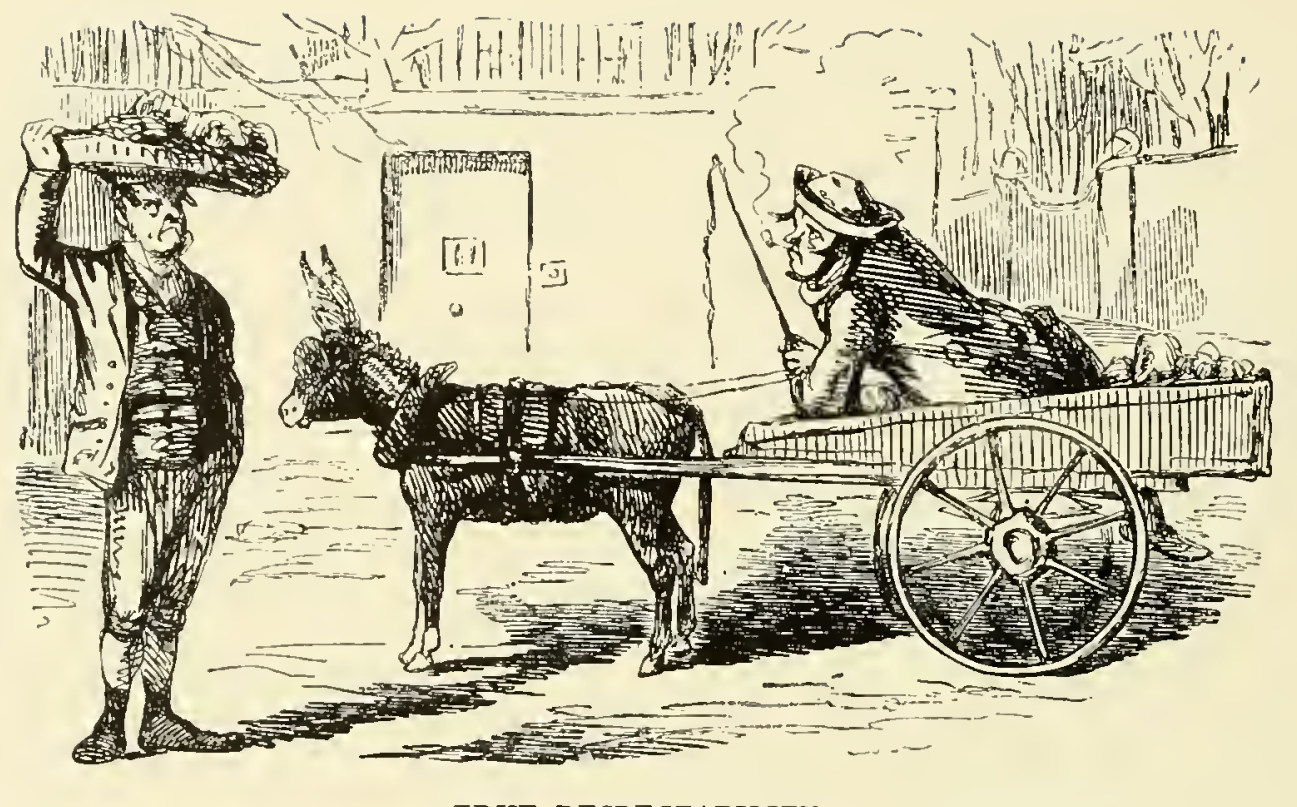

TRUE RESPECTABILITY.

First Costcrmongcr. "I wonder a respectable cove like you, Bill, carries your own collyflowers! Why don't yer keep a carridge like mine?"

Second Costcrmonger. "Why don't I keep a carridge? Why, because I don't choose to waste my hincum in mere show and fashionable display!" 


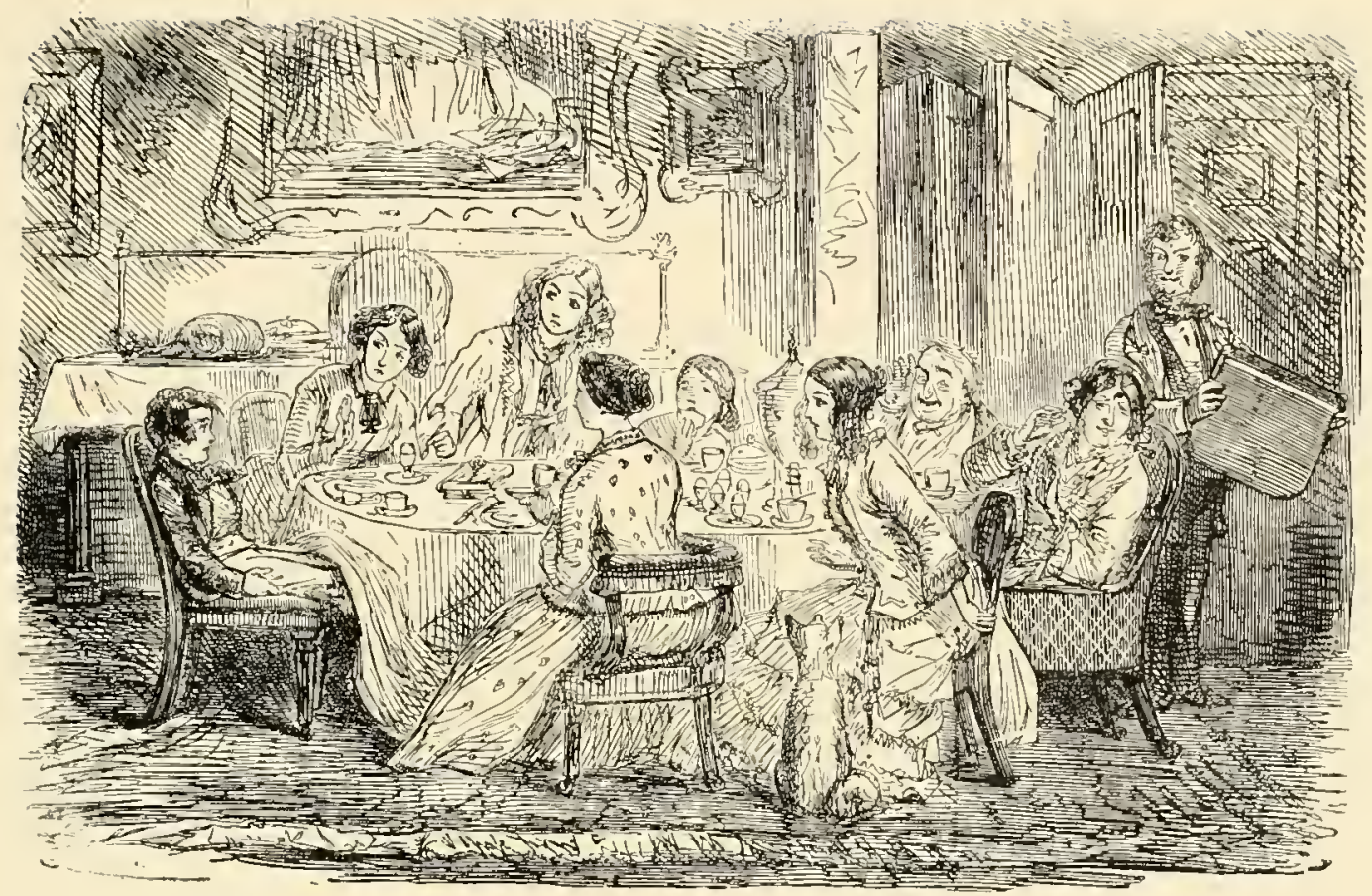

WALTONIANS.-SCENE.-ROOM IN COUNTRY-HOUSE.-BREAKFAST-TIME.

Mastcr Tont. "Oh, Robert!"

Kobert. "Yes, Sir!"

Mastcr Tom. "Oh, I say, Robert! The ladies want me to take 'em out fishing to-day, so just tell young Evans I shall want him to go with me to get some wasp grubs; and-look here! Tell the gardener he must get me some large lobworms directly, and a few small frogs, as perhaps we shall try for a jack. And-hi! Robert, tell him to send 'em in here, that I may see whether they're the right sort!" (General Exclanation of "Nasty Monkey!" from the Ladies. Old Gentlenon being rather dea! wishes MASTER TOM's remarks repeated.) 


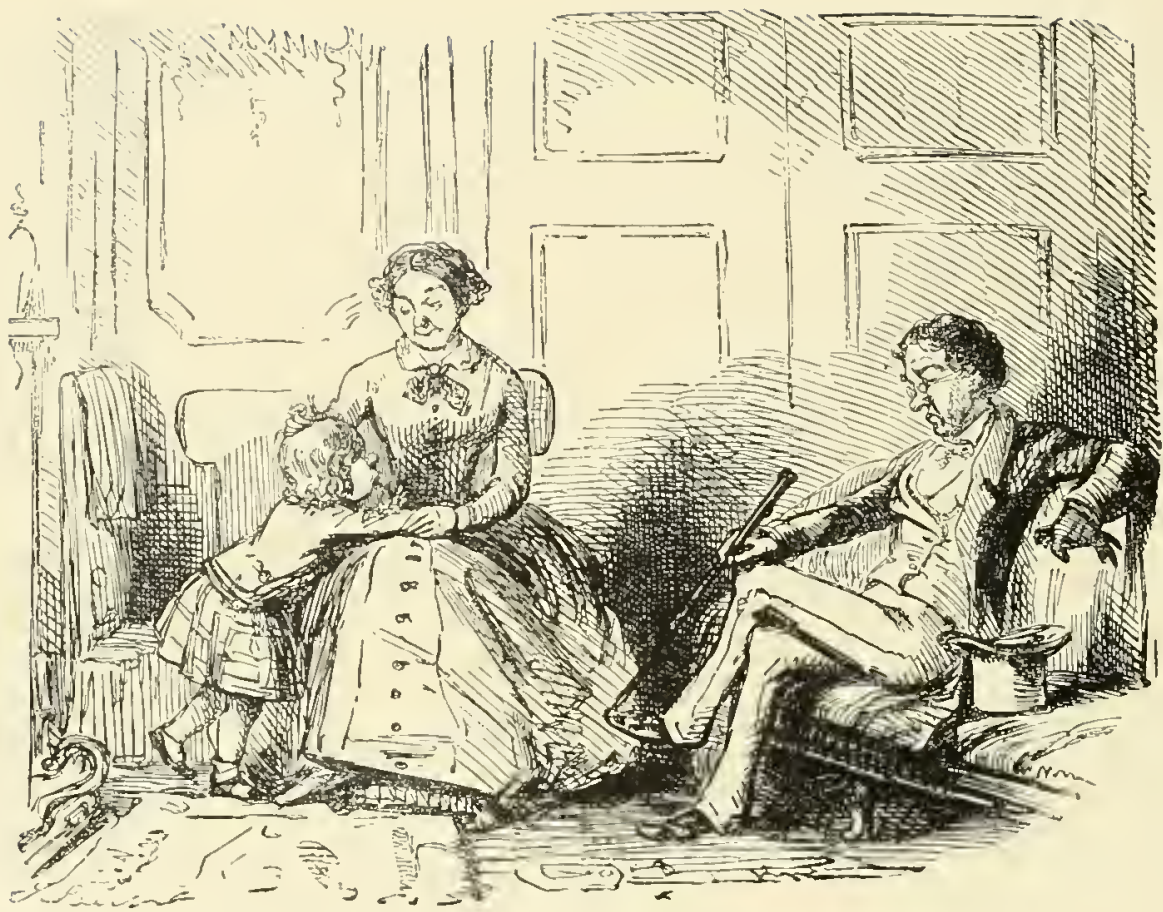

PERFECT SINCERITY; OR, THINKINGS ALOUD.

Mamma. "You are a disagreeable old bachelor, and generally hate children, I know - but isn't dear little Wormwood a fine, noble little fellow!"

Old Gent. "Well, if you want my candid opinion, I may as well tell you at once-that I think him the most detestable little beast I ever saw-and if you imagine I am going to leave him anything because you have named him after me. you are mightily mistaken." 


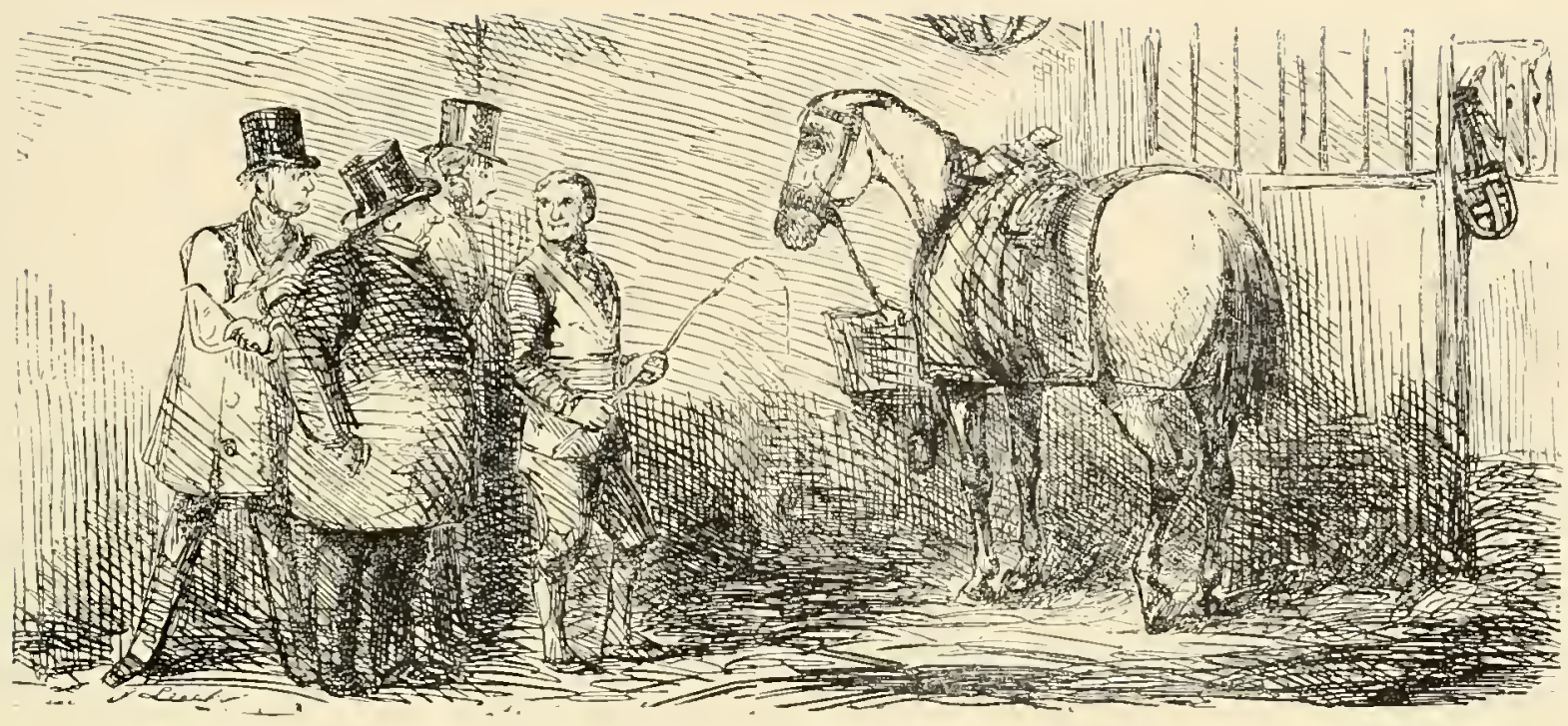

Groom. "That's another favourite oss of master's, Sir, and a good un he is, too, Sir, only he ain't very quiet." Mr. Green. "Oh, how do you mean- Not very quiet?"

Groom. "Why, Sir, he'd get you up in a corner and kick yer brains out in no time. He's a'most killed two men already." 


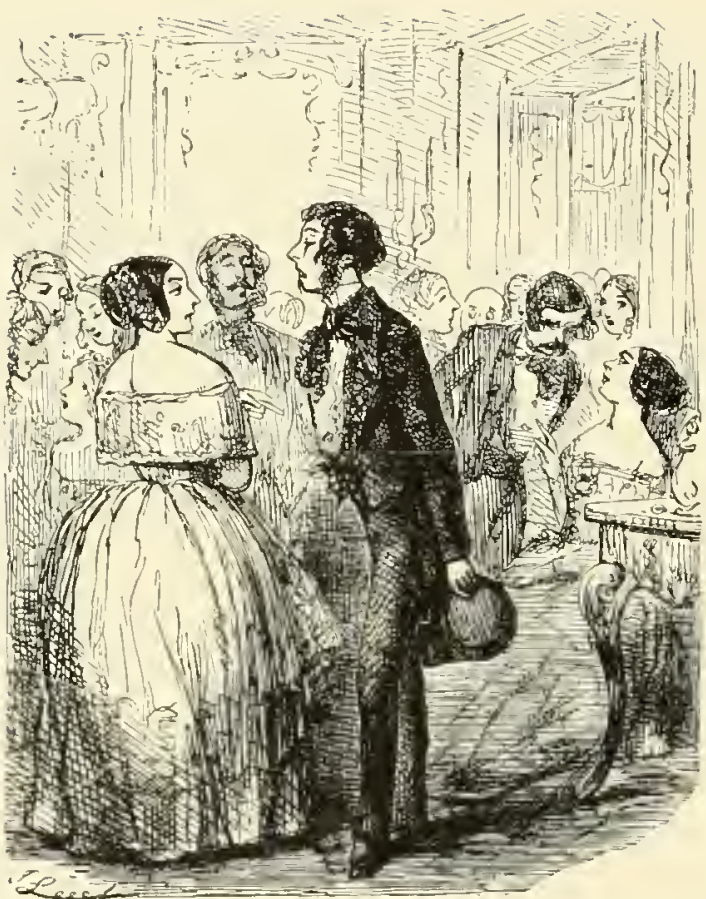

PERFECT SINCERITY; OR, THINKINGS ALOUD.

"Are you going?"

"Why, ye-es. The fact is, that your party is so slow, and I am weally so infernally bored, that I shall go somewhere and smoke a quiet cigar."

"Well, good night. As you are by no means handsome, a great puppy, and not in the least amusing, I think it's the best thing you can do."

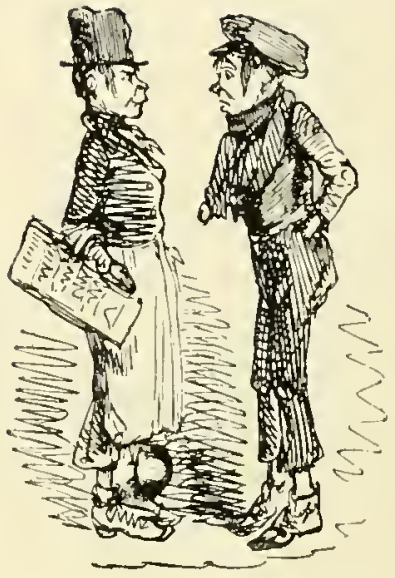

STREET DIALOGUE.

First Boy". "I'll punch ye: ed, if yer say much."

Sccond Boy. punch my ed?"

First Boy. "I will."

Second Boy. "You will?"

First Boy. "Yes, I will."

Sccond Boy. "Well!-Do it."

First Boy, "Ah!"

Second Boy. "Yes!"

First Boy. "Oh!"

(Boy's craporate). 


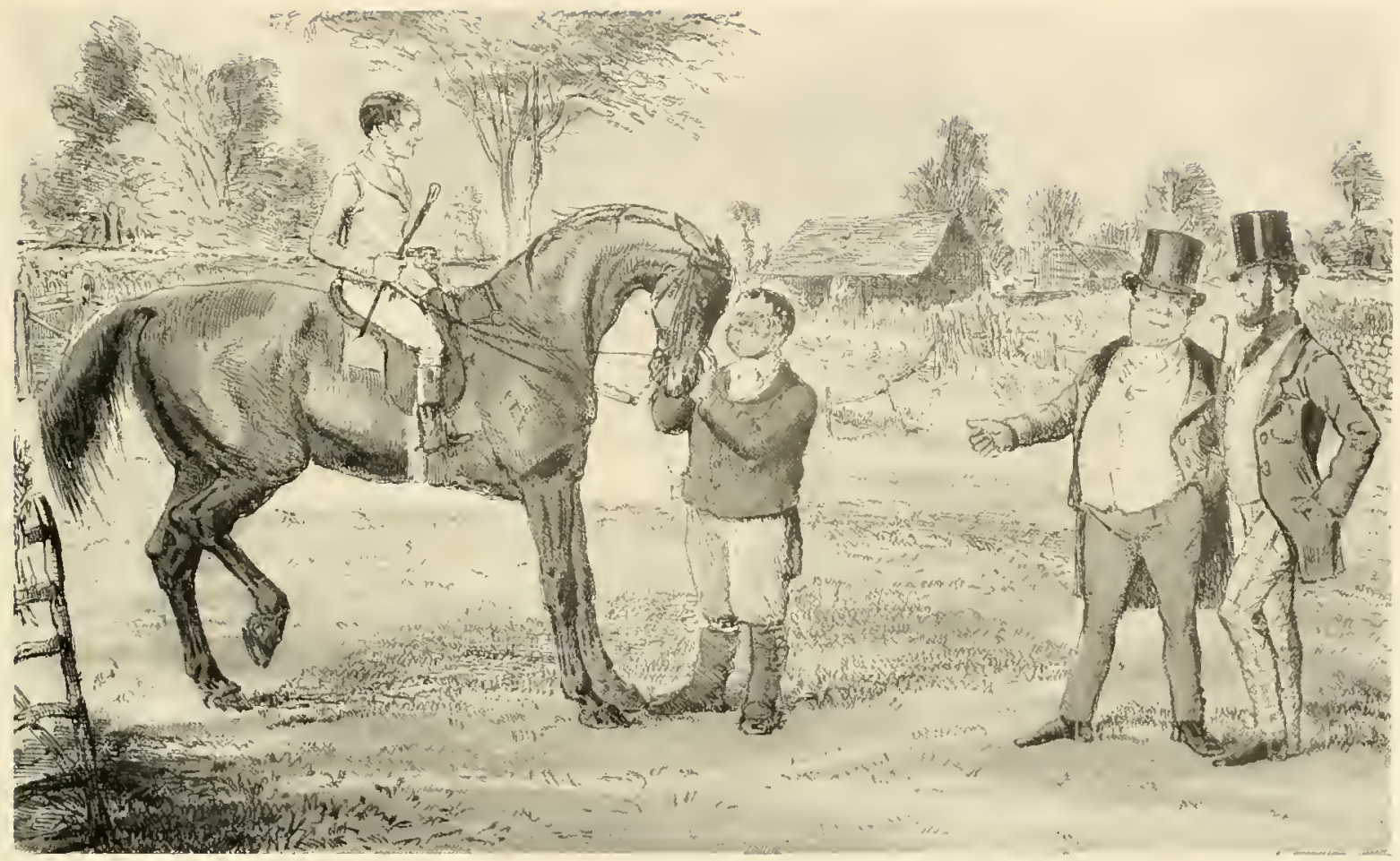

Mr. Sponge is introduced to "Ercles."-From "Mr. Spongc's Sporting Tour." 


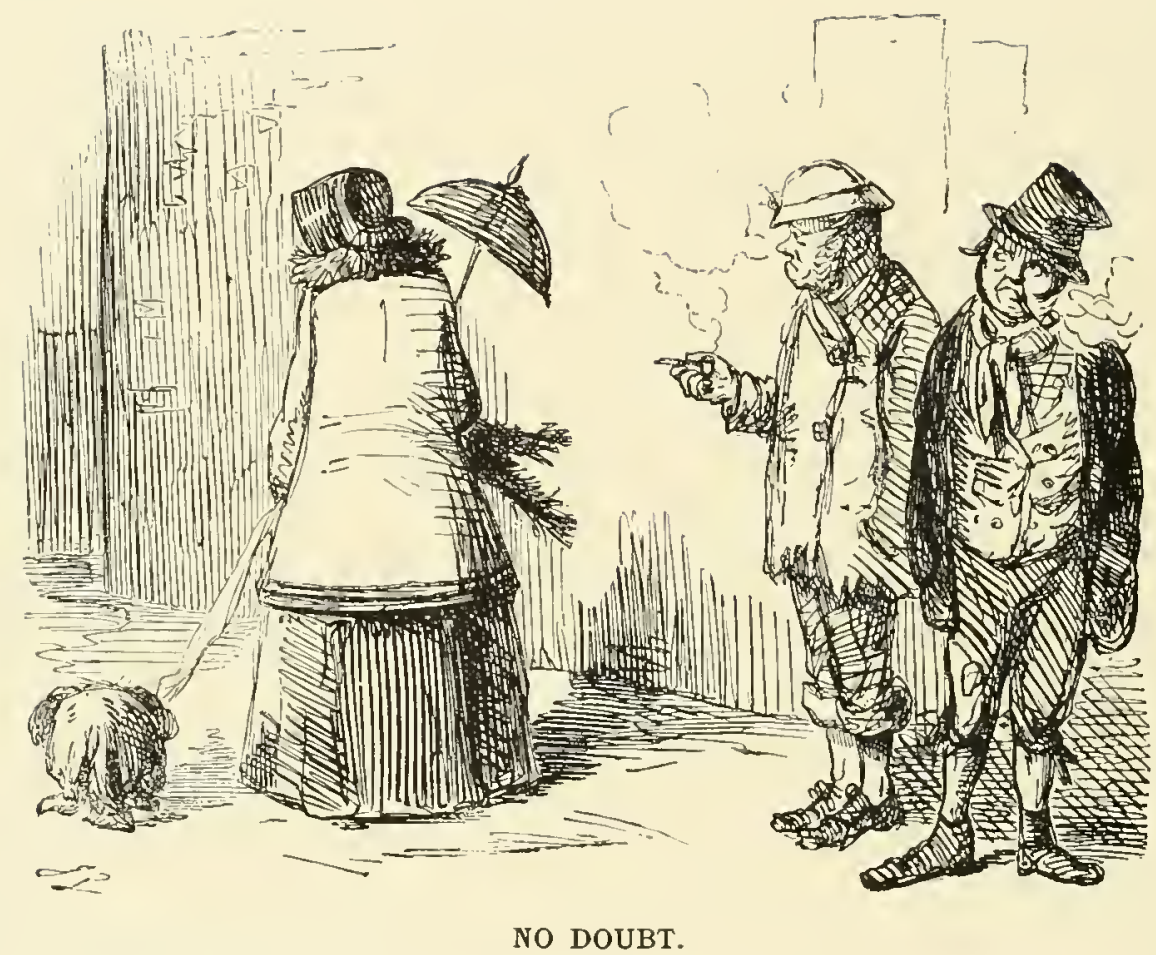

"Now I dare say, Bill, that air beast of a dog is a good deal more petted than you or I should be." 


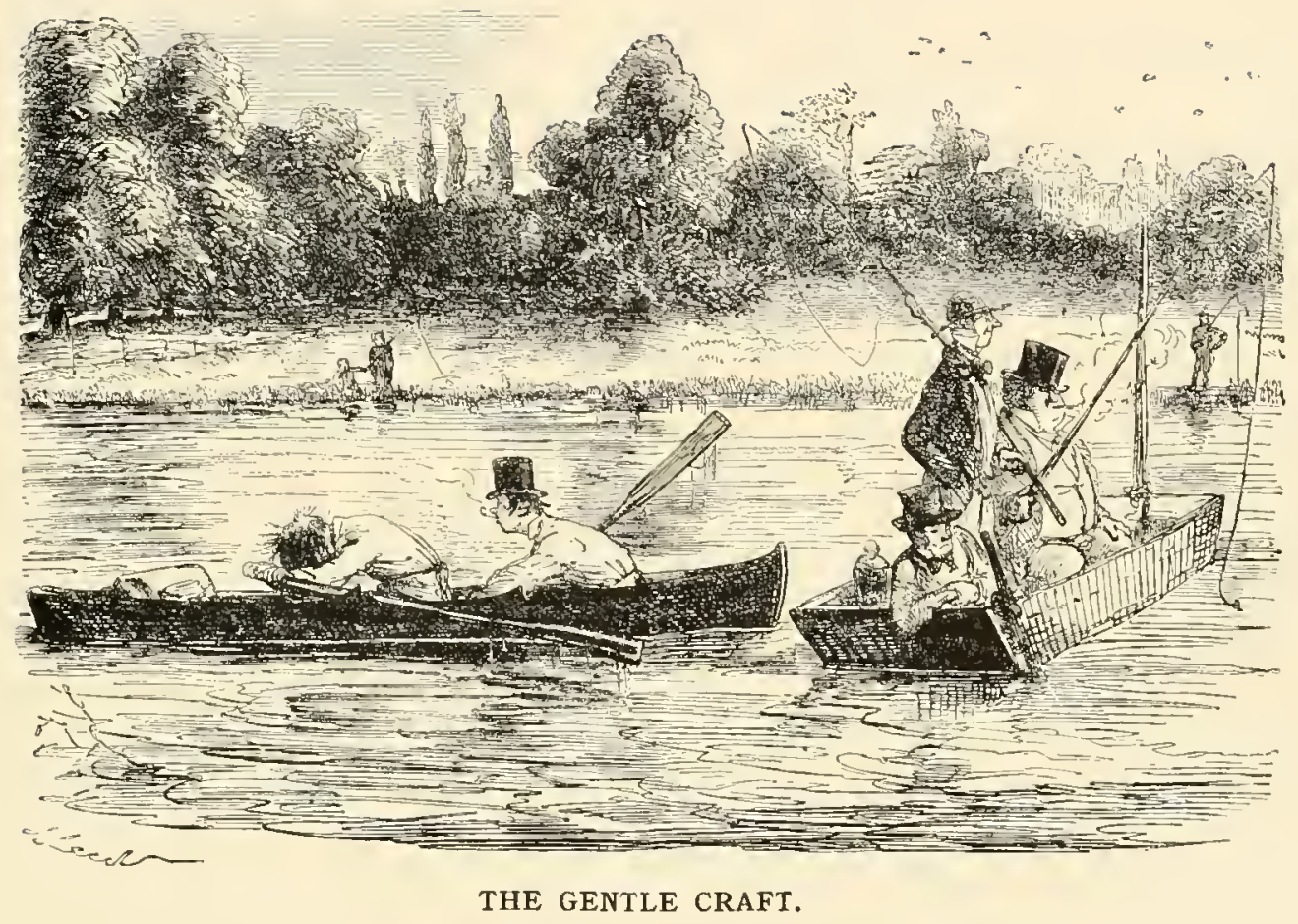

Contemplative Man (in punt). "I don't so much care about the sport, it's the delicious refose I enjoy so." 


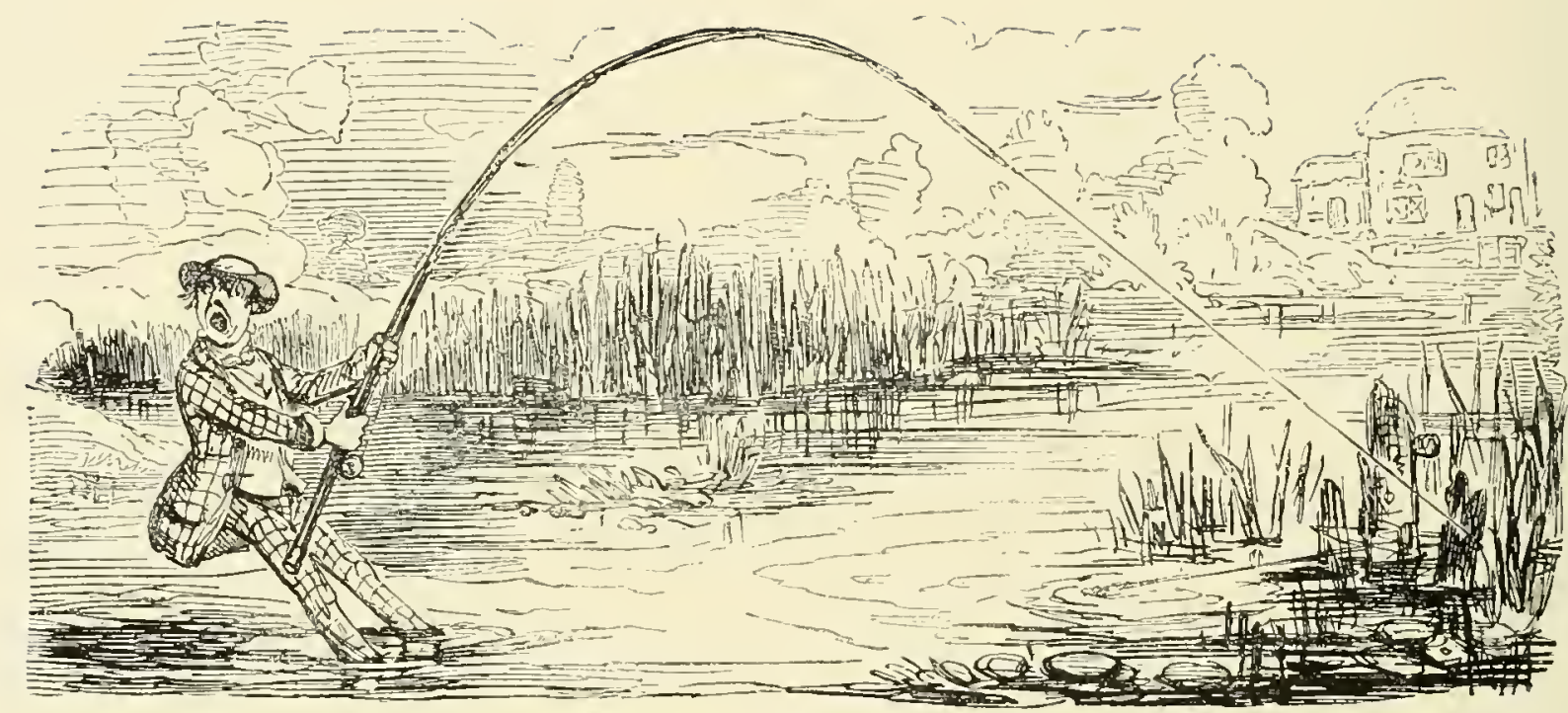

a PLEASANT State of things.

Piscator (at the top of his voice). " $\mathrm{Hi}$--Tom! Bring the landing-net; he's pulled me in, and got round a post." 


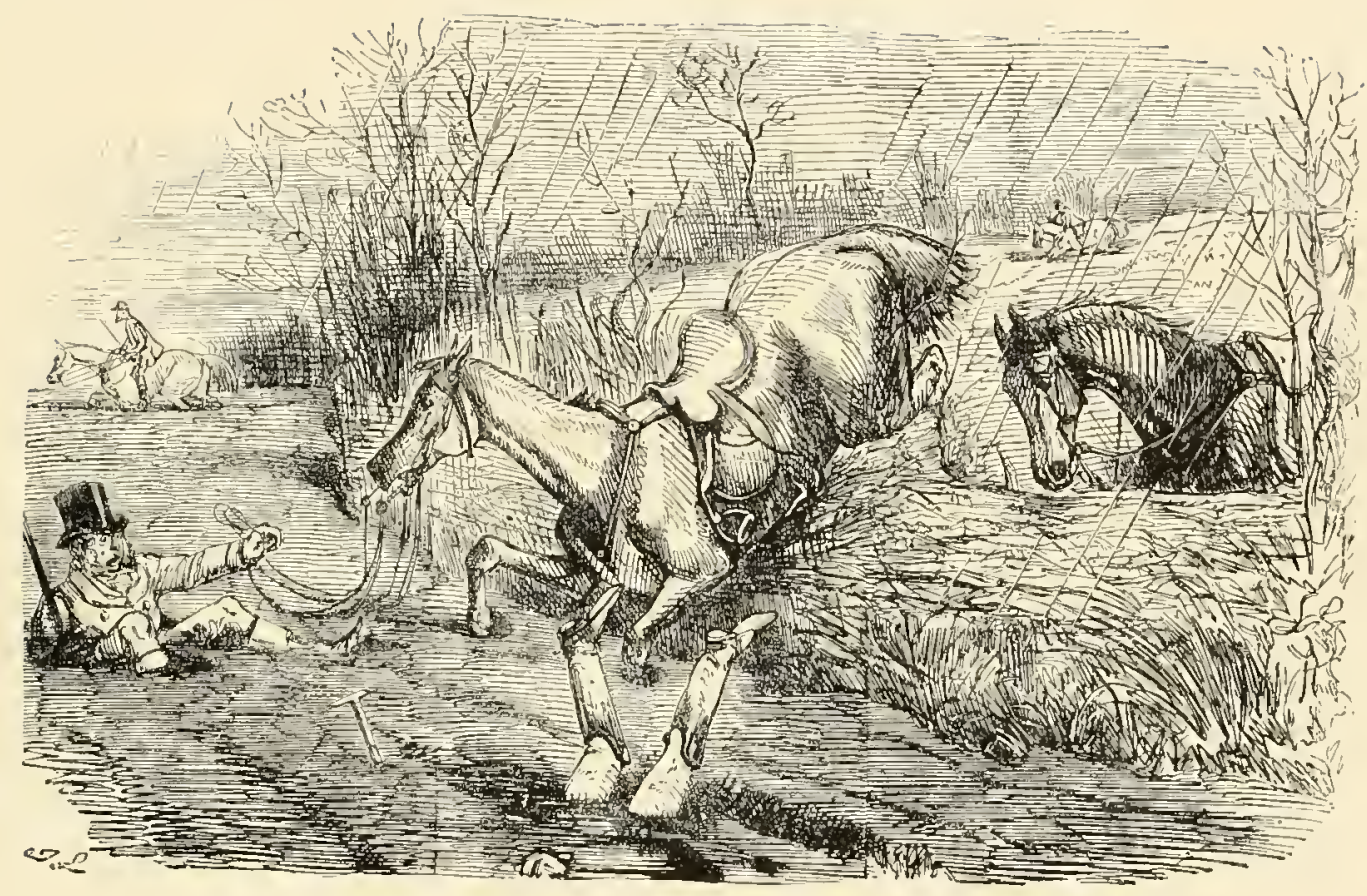

SPORTING INTELLIGENCE.-(FROM OUR OWN CORRESPONDENT.)

"The country is awfully deep, but the falling is delightfully soft and safe." 


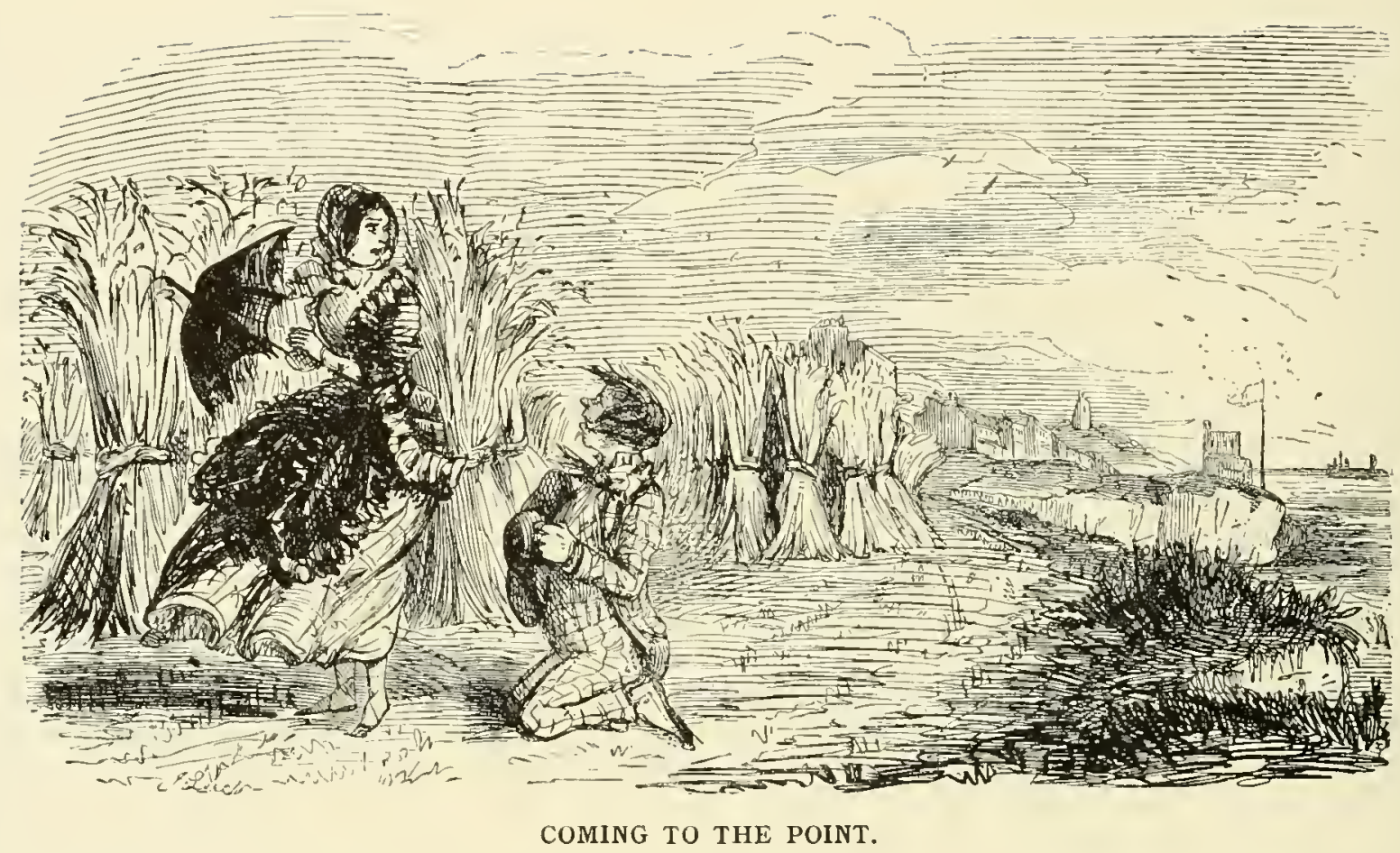

Lover. "Sweet girl, let me-here - away from the busy hum of men-and where no mortal eye can see usdeclare that passion which - which-_."

Lady. “There! for goodness' sake get up, Mr. Tomkins, and don't be ridiculous just consider all the telescopes from the parade!!" 


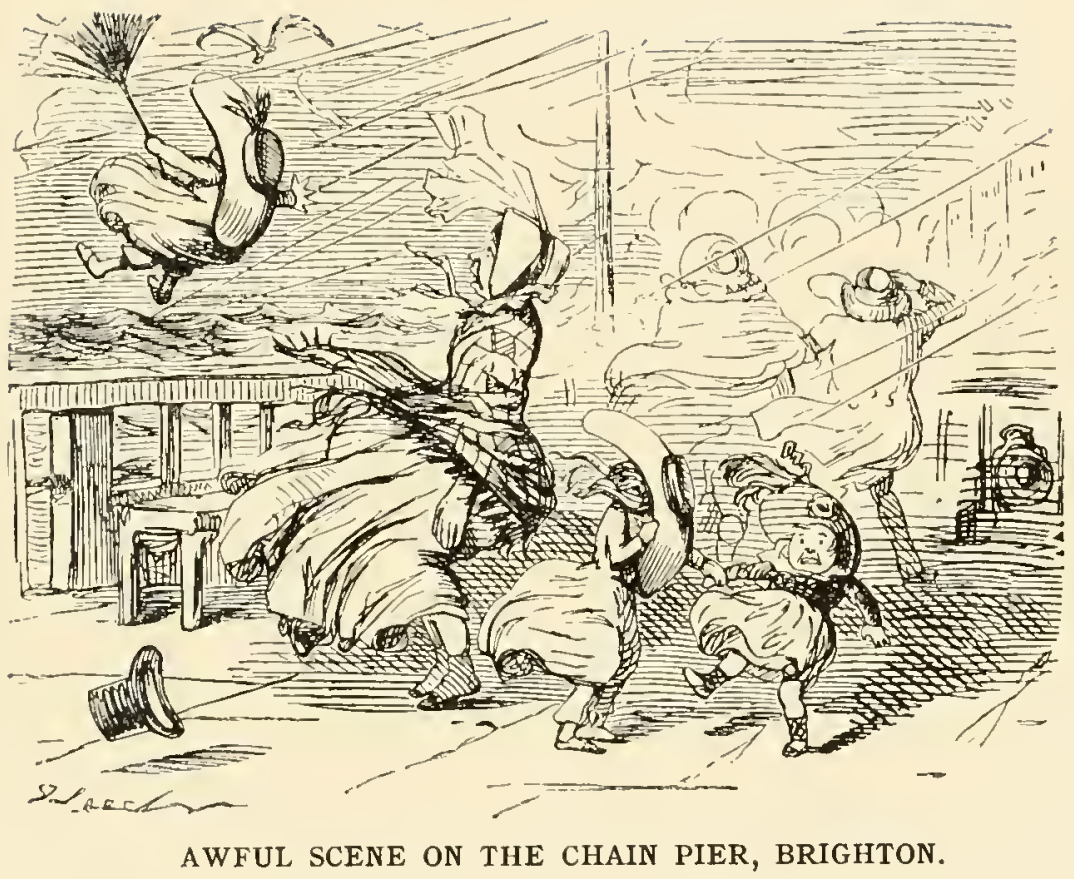

Vursemaid. "Lawk! there goes Charley, and he's took his Mar's para -1. What will Missus say?" 


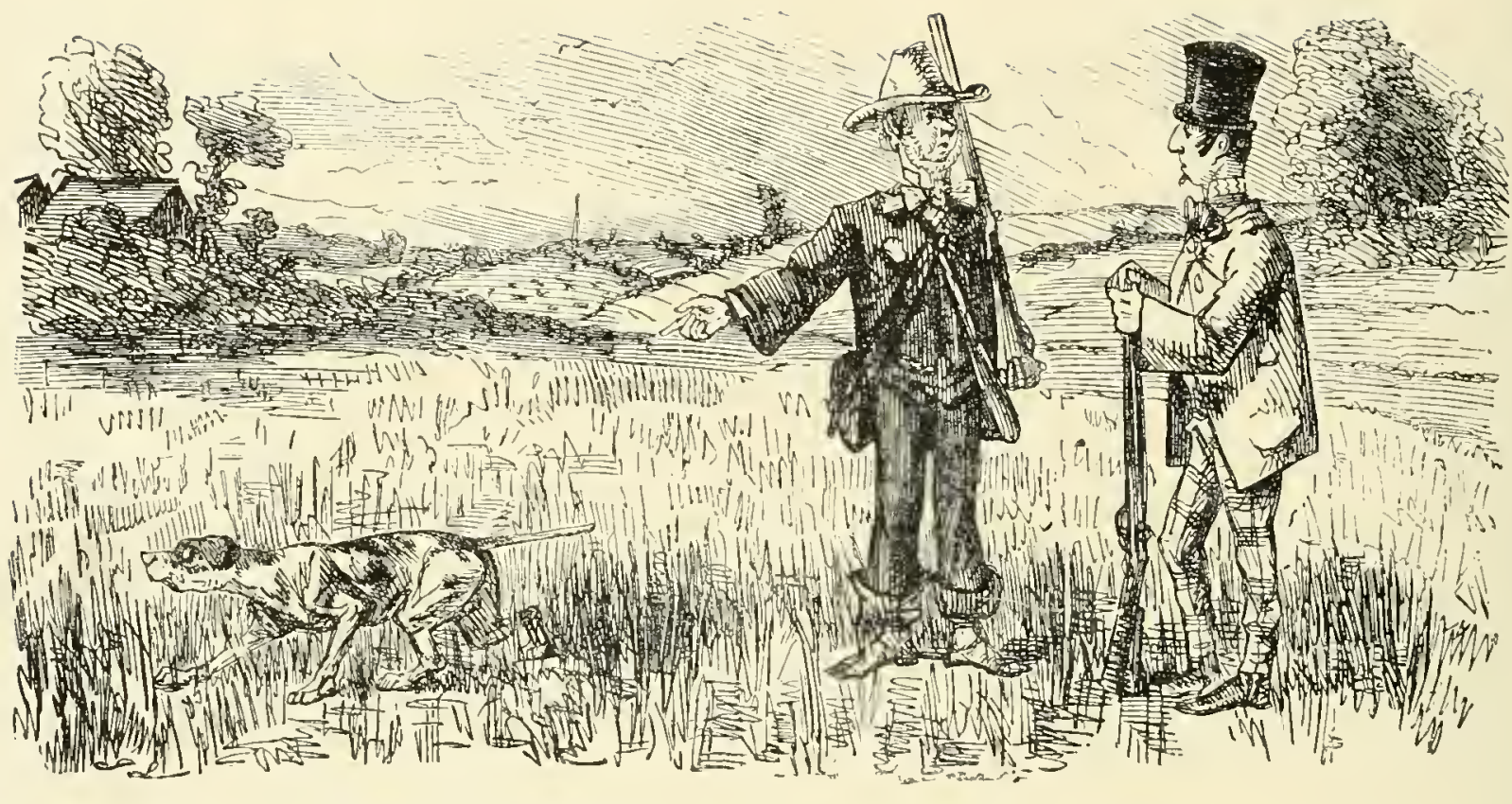

SPORTING EXTRAORDINARY - THE OLD DOG POINTS CAPITALLY.

"I tell yer what it is, Sam! if this fool of a dog is going to stand still like this here in every field he comes to, we may as well shut up shop, for we shan't find no partridges." 


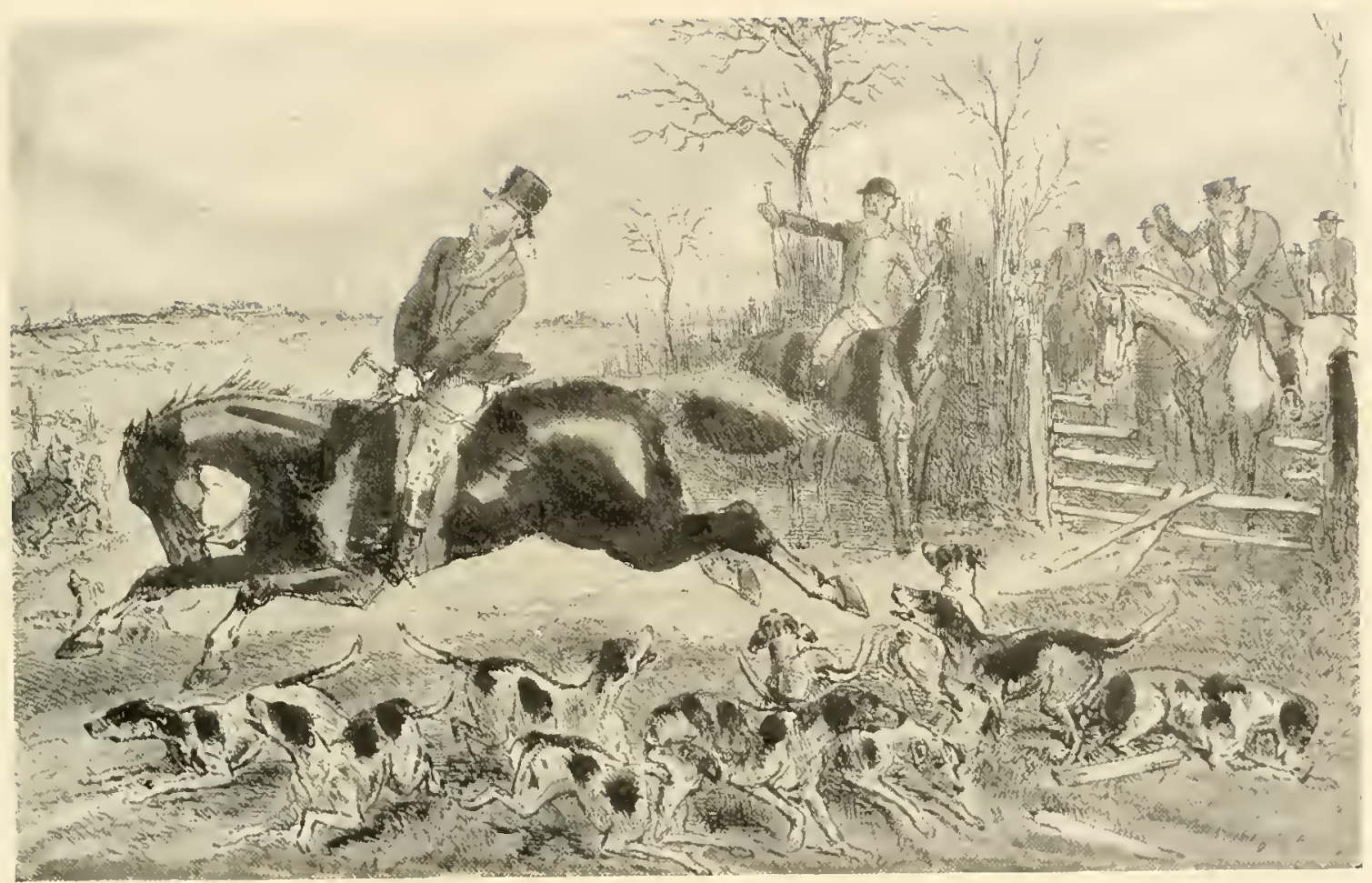

One of Multum in Parvo's "going " days, -From "Mr. Sponge's Sporting Tour." 


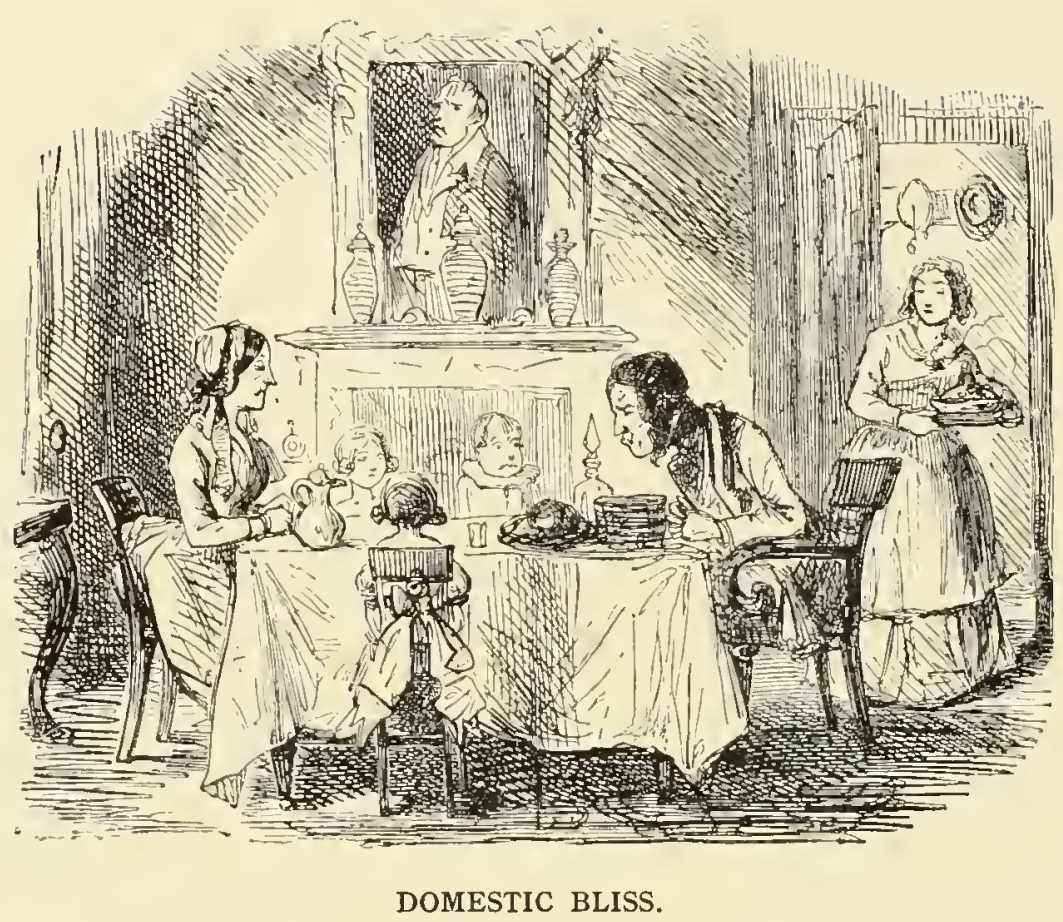

Head of the Family. "For what we are going to receive, make us truly thankful.- - Hem! cold mutton again!"

IVife of his Bussum. "And a very good dinner too, Alexander. Somebody must be economical. People can't expect to have Richmond and Grecnwich dinners out of the little housekeeping money I have." 


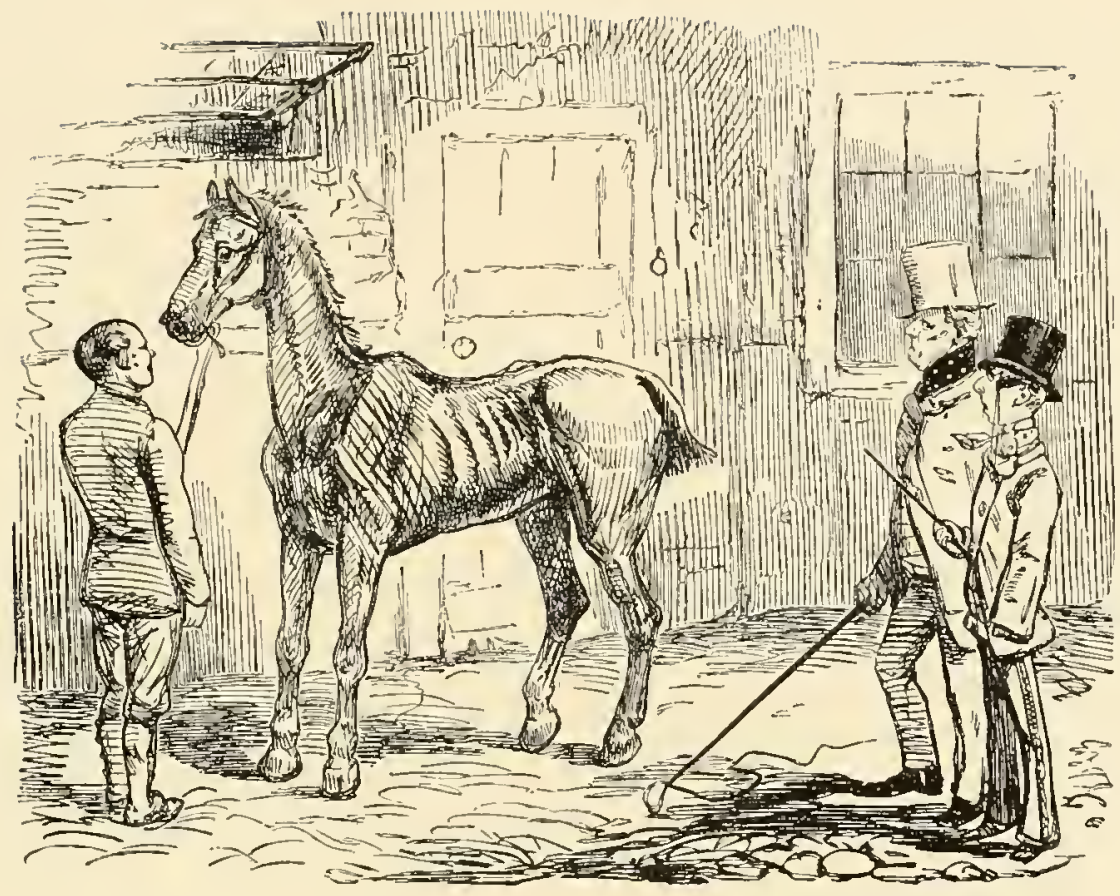

ROOM FOR IMPROVEMENT.

Dealer. "There. He ain't a 'orse made up for sale. He'll go on improvin' every day you keep him-he will." 


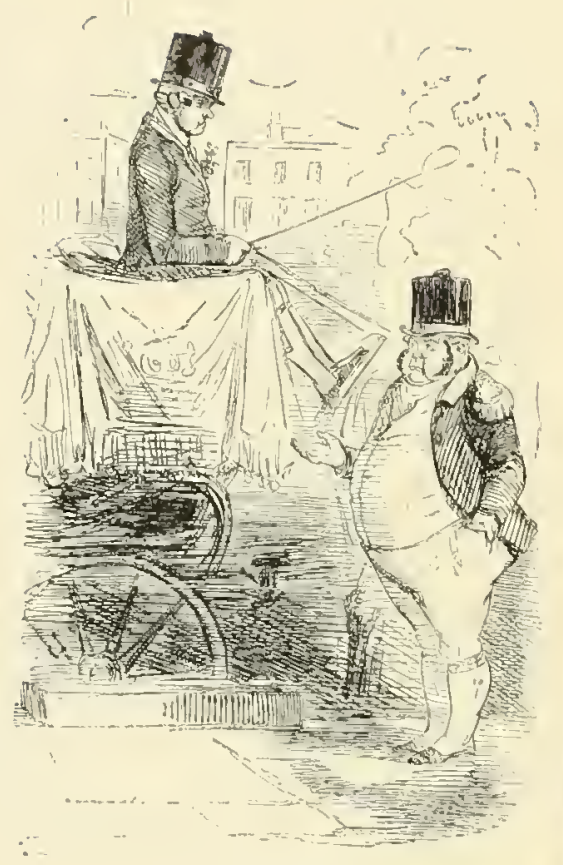

FLUNKEIANA.

Coachman. "Why-what's the matter, John Thomas?"

Footman. "Matter enuff! here's the Marchioness bin an giv me notice because I don't match Joseph, and I must go, unless I can get my fat down in a week!"

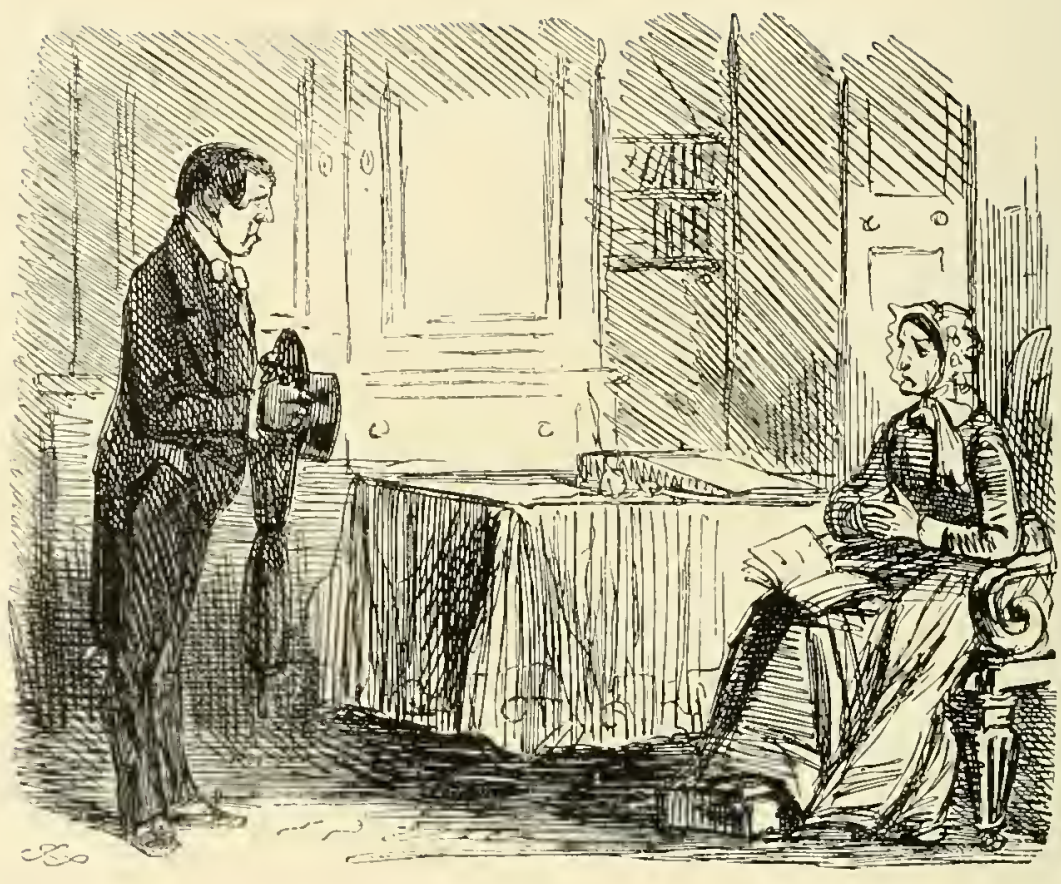

\section{FLUN KEIANA.}

Scrions Flunkey. "I should require, Madam, forty pounds a year, two suits of clothes, two 'ats, meat and hale three times a day, and piety hindispensable." 


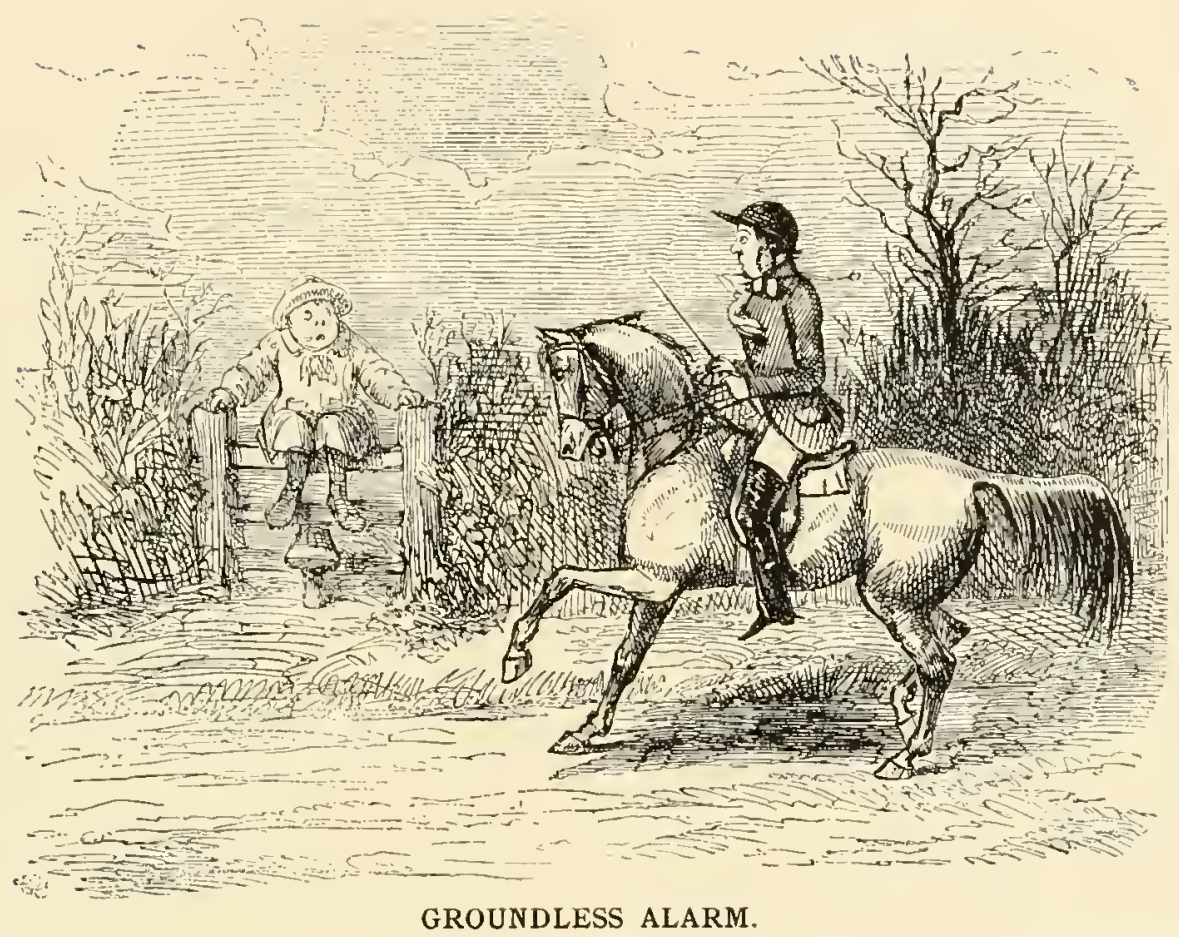

Equestrian. "Now, boy, don't you be taking off your hat to make me a bowyou'll frighten my horse."

Boy". "A-A-A warn't a-going to!" 


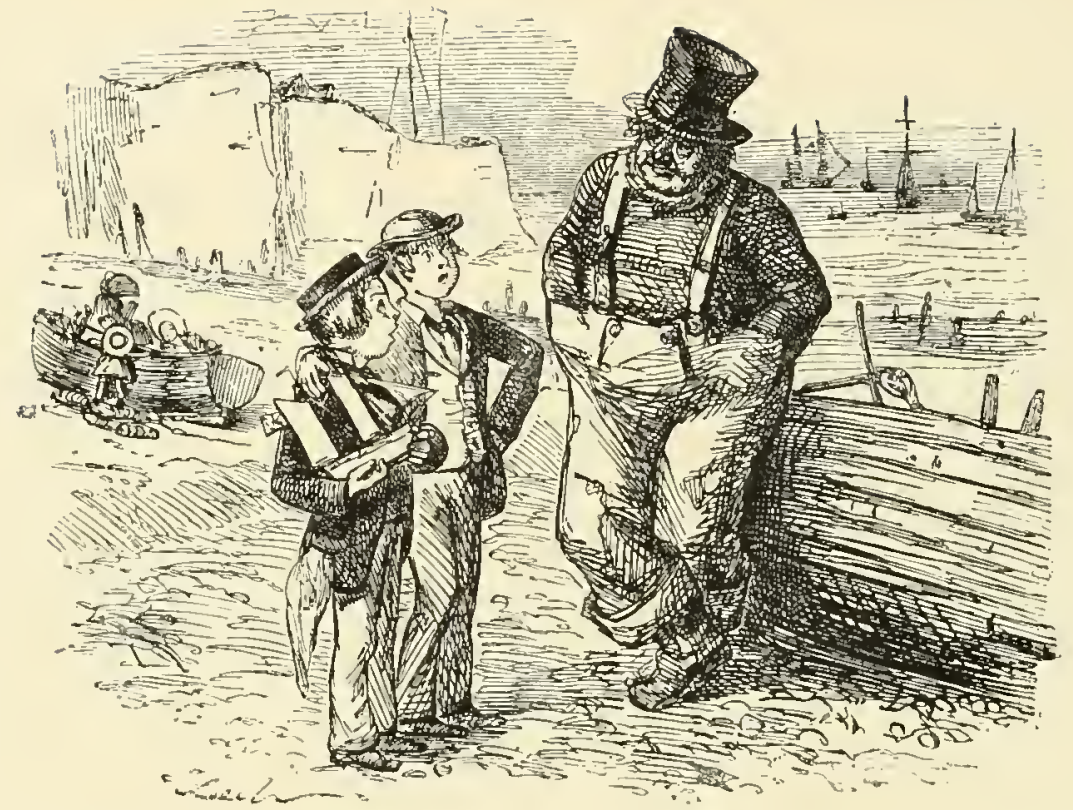

A WATERING-PLACE YARN.

Youths. "Then, I suppose, when you were a smuggler, you used to have reg'lar combats and fights!"

Boatman. "Combats and Fights! Lor love yer, we wos a'most always at it. Once in partickler I call to mind. There was me and BILL BOKER (BLACK BiLL we had used to call him) and four more had just run a cargo-(middle of the night it wos, and so uncommon dark you couldn't see an inch afore yer)-had just run a cargo of 'Ollands and pocket handkerchers - when we see about a hundred yards from where we wos -a-comin' down the clift - the Coast Guard! Well! without saying a word, blowed if they didn't up pieces and let fly right at us. We fired agin-and-dear eyes! p'raps the bullets warn't flying about neither! It wos desprit wurk-we wos fightin' 'most all night!"

Iouths. "Lor! and which won?"

Boatman. "Oh-we won! But we wos wounded awful! BiLl BOKER wos shot in the leg and in the harm-so woS JIM JAWLEY - and I had three balls through my head and two in the stummuck (wich I feel 'em now sometimes in the winter I do), besides bein' run through with a cutlass, and all my front teeth knocked out by the Perwentive man's telescope, wich luckily shut up or there's no knowin' wot might 'a bin the consequence. Ah! there wos goins on then. But lor, it ain't nothin' like it now!" (Youths are decply impressed.) 


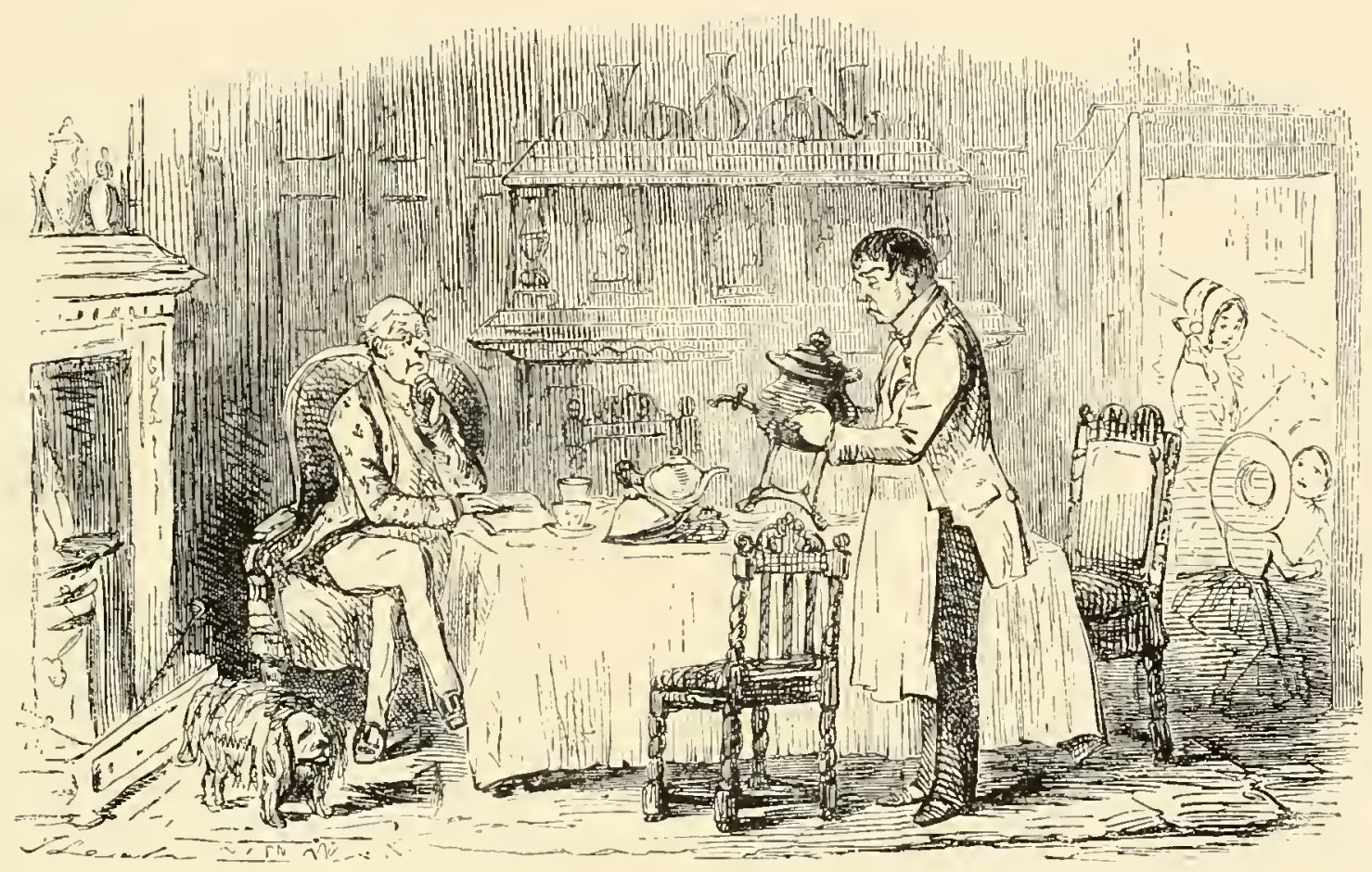

FLUNKEIANA.-Enter Thomas, who gives wurning.

Gentleman. "Oh, certainly! you can go, of course; but, as you have been with me for nine years, I should like to know the reason."

Thomas. "Why, Sir, it's my fcelins. You used always to read prayers, Sir, yourself-and since Miss Wilkins has been here, she's bin a-reading of 'em. Now, I can't bemean myself by sayin' 'Amen' to a guv'ness." 


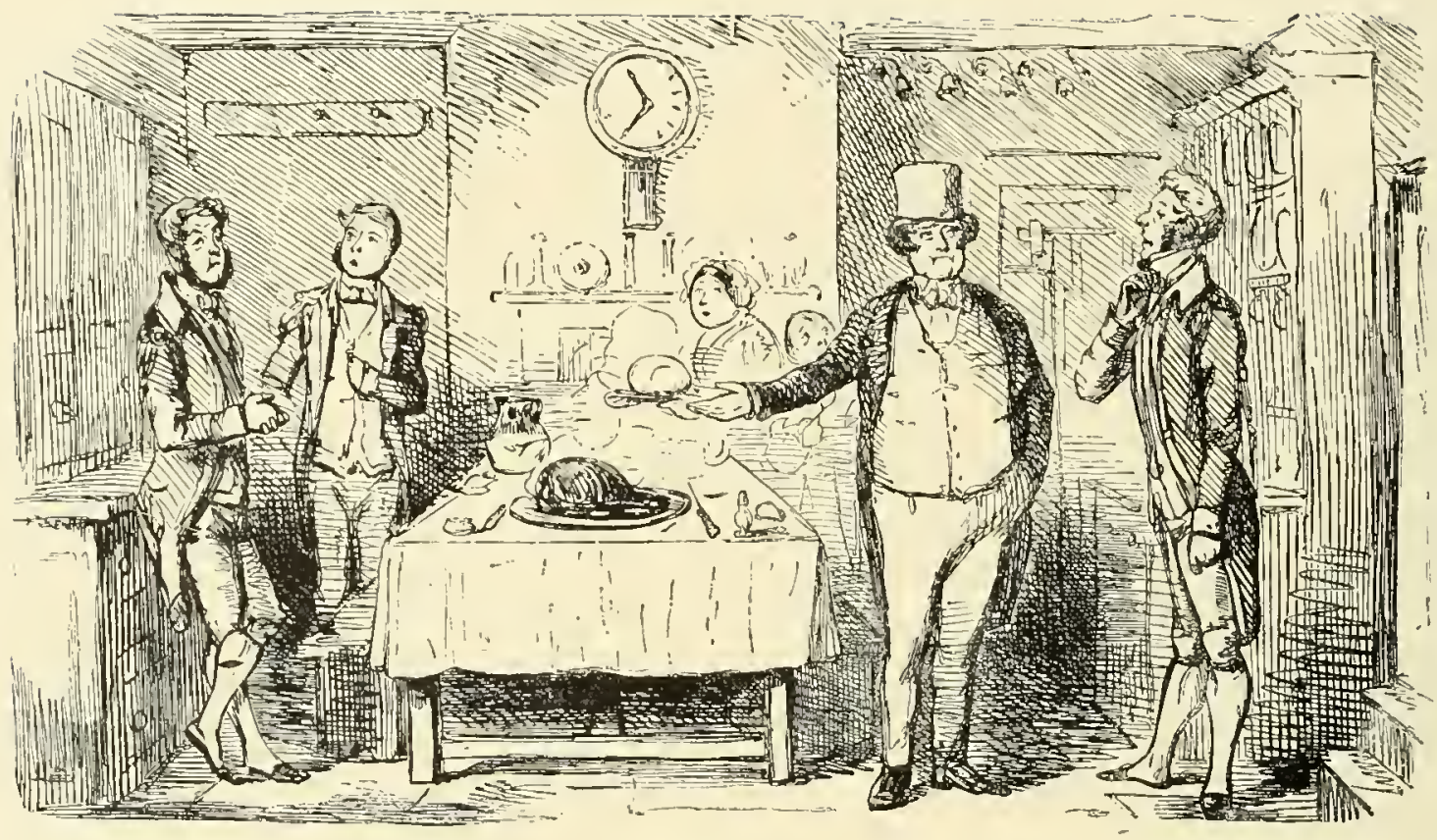

FLUNKEIANA.

Master of the Honse. "Now, pray what is it you complain of? Is not a roast leg of mutton, with plenty of pudding, vegetables, and beer, a substantial dinner enough for you?"

Flunkey. "Oh! substantial enough, no doubt, Sir; but it really is a quizzeen that-aw-me and the other gentlemen has not bin accustomed to. It's very corse-very corse indeed, Sir! !" 


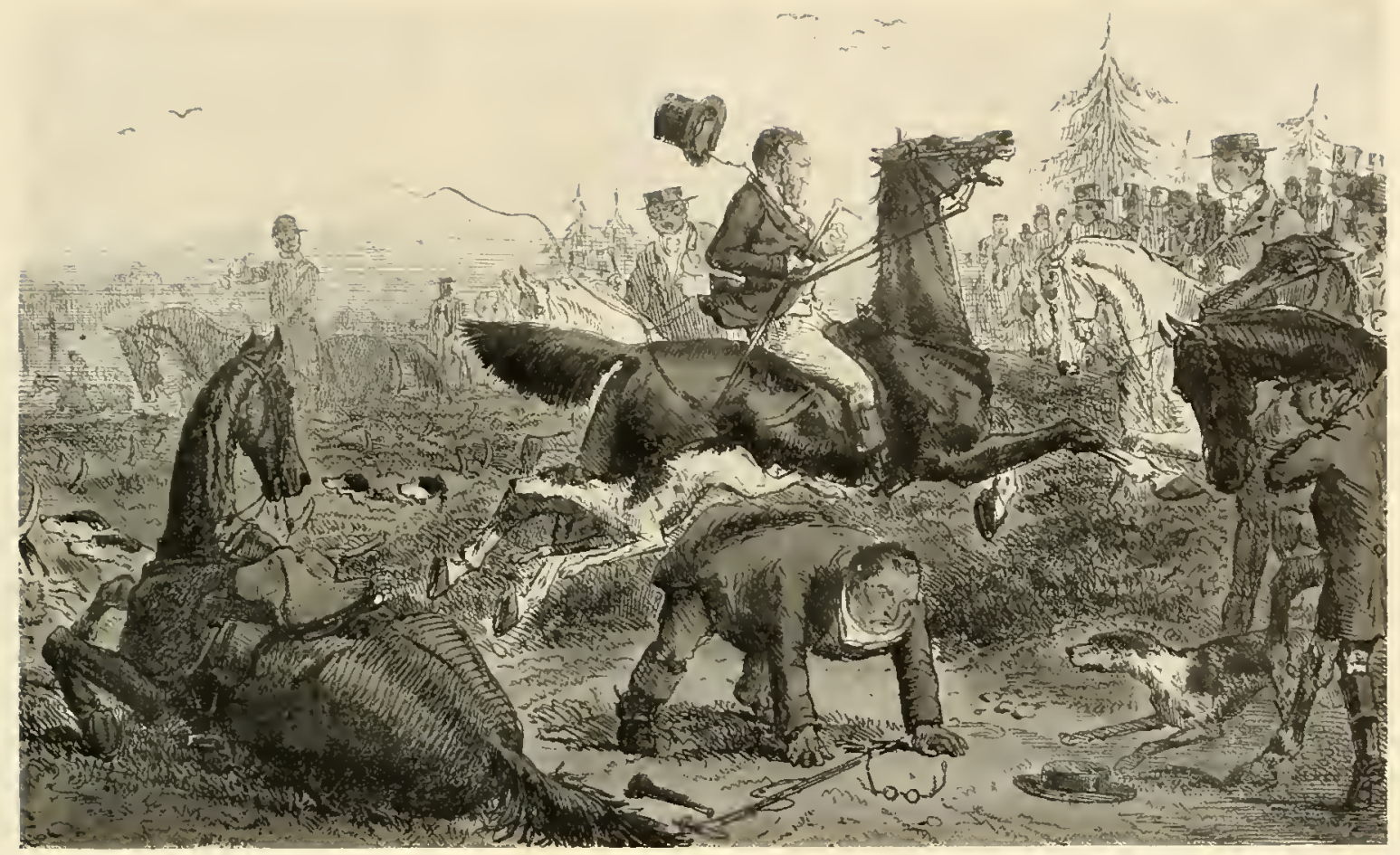

Mr. Sponge completely scatters his Lordship.-From "Mr. Sponge's Sporting Tour." 


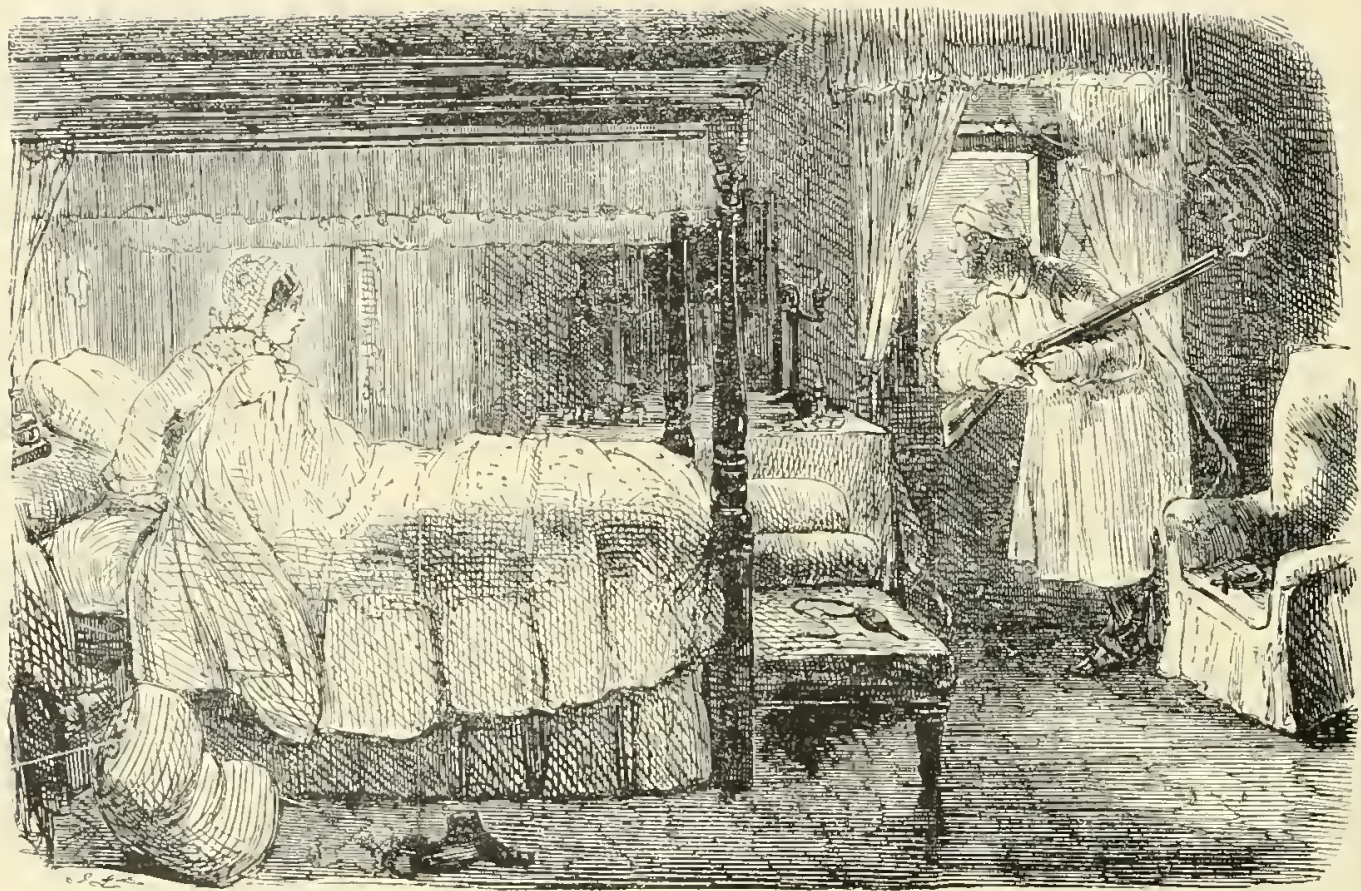

DOMESTIC BLISS.

II'ife (much sturtled). "Good gracious, Reginald! what are you doing with that gun?" Reginald (who is very' fond of shooting). "Hush! hush! my dear-I've killed two!" II ifc. "My goodness! Two what? - thieves?"

Reginald. "No, dear. Two of those confounded rabbits that are always eating the verbena! There, go to sleep, darling-I'll have another directly." 


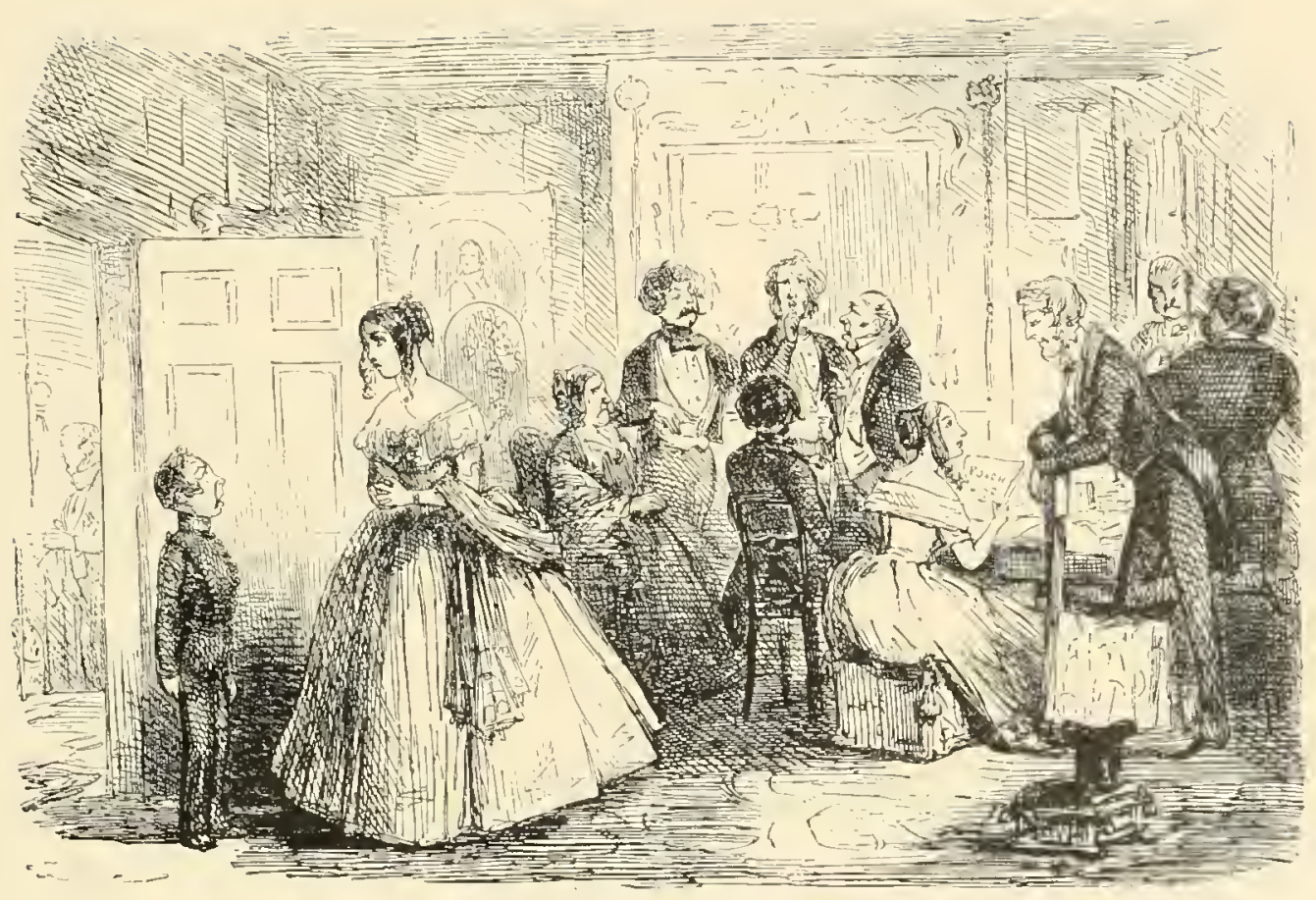

THE LITTLE DINNER PARTY.

Buy. "Oh! If you please 'm-cook's very sorry 'm-but could she speak to you a moment?" 


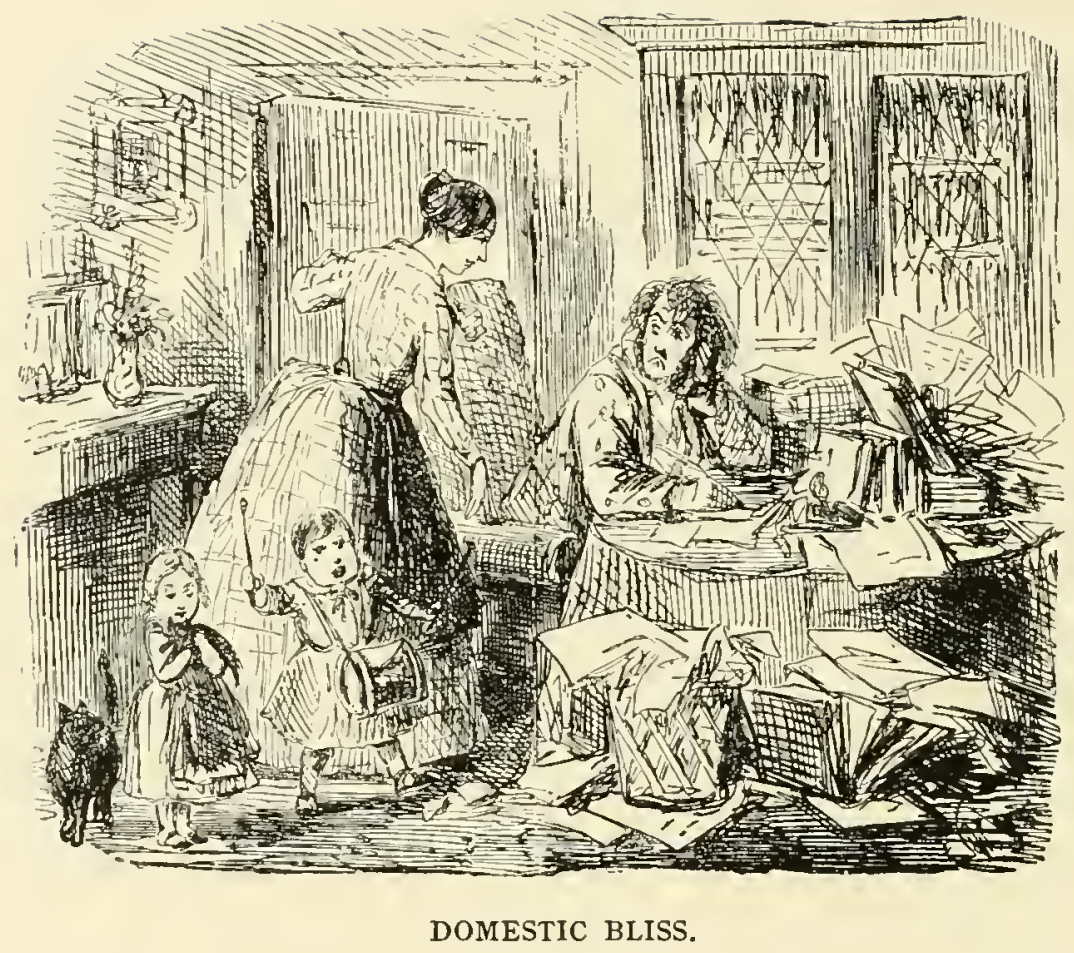

Trife of your Bussum. "Oh, I don't want to interrupt you, dear. I only want some money for baby's socks-and to know whether you will have the mutton cold or hashed." 


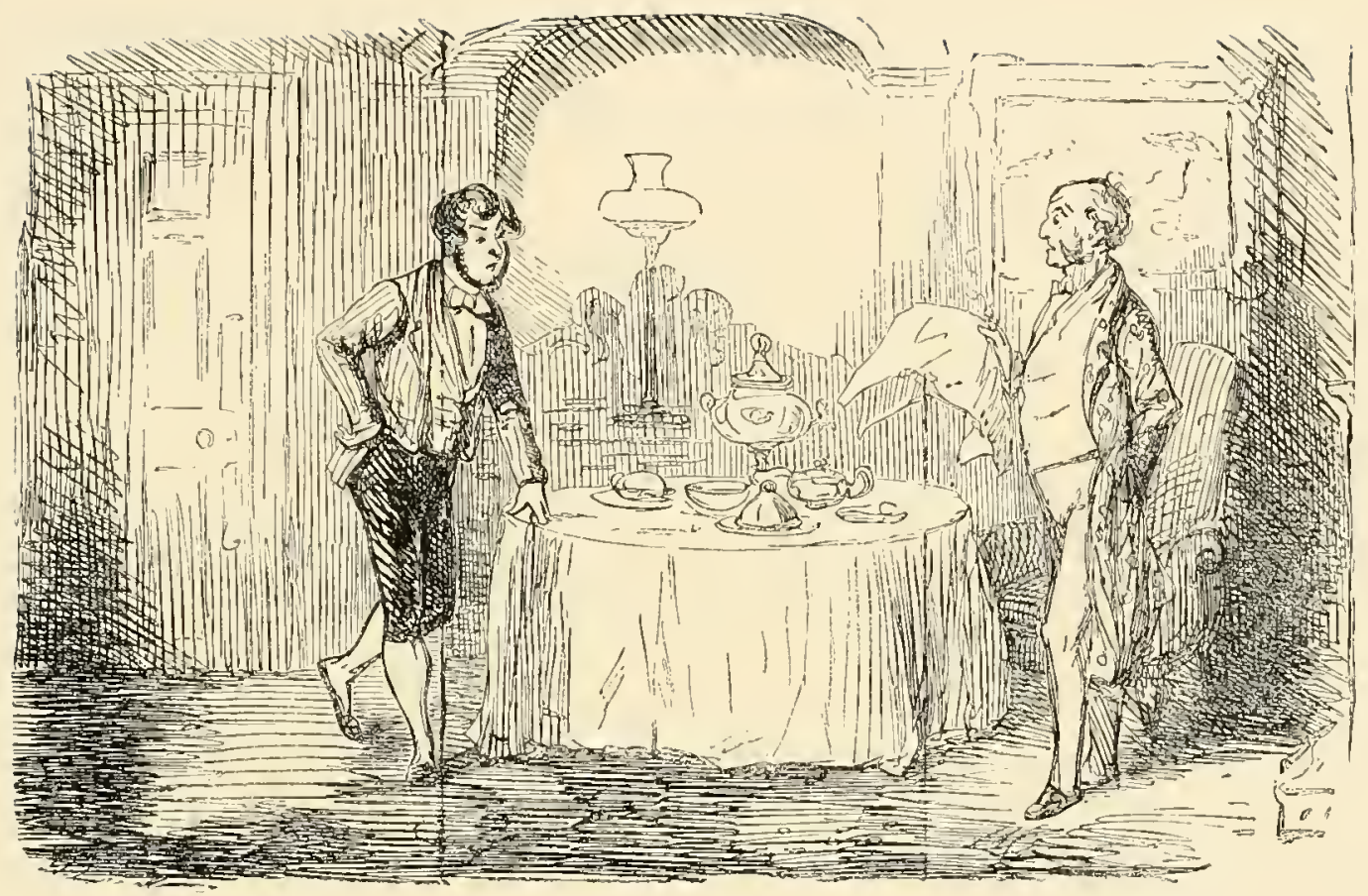

FLUNKEIANA.

Flunkcy. "I beg your pardon, Sir - but there is one thing I should like to mention at once. I am afraid - a- that $I$ am expected to clean the boots."

Gcnllcman. "Bless me! oh dear, no! there must be some mistake; I always clean them myselfand if you will leave your shoes outside your door, I will give them a polish at the same time." 


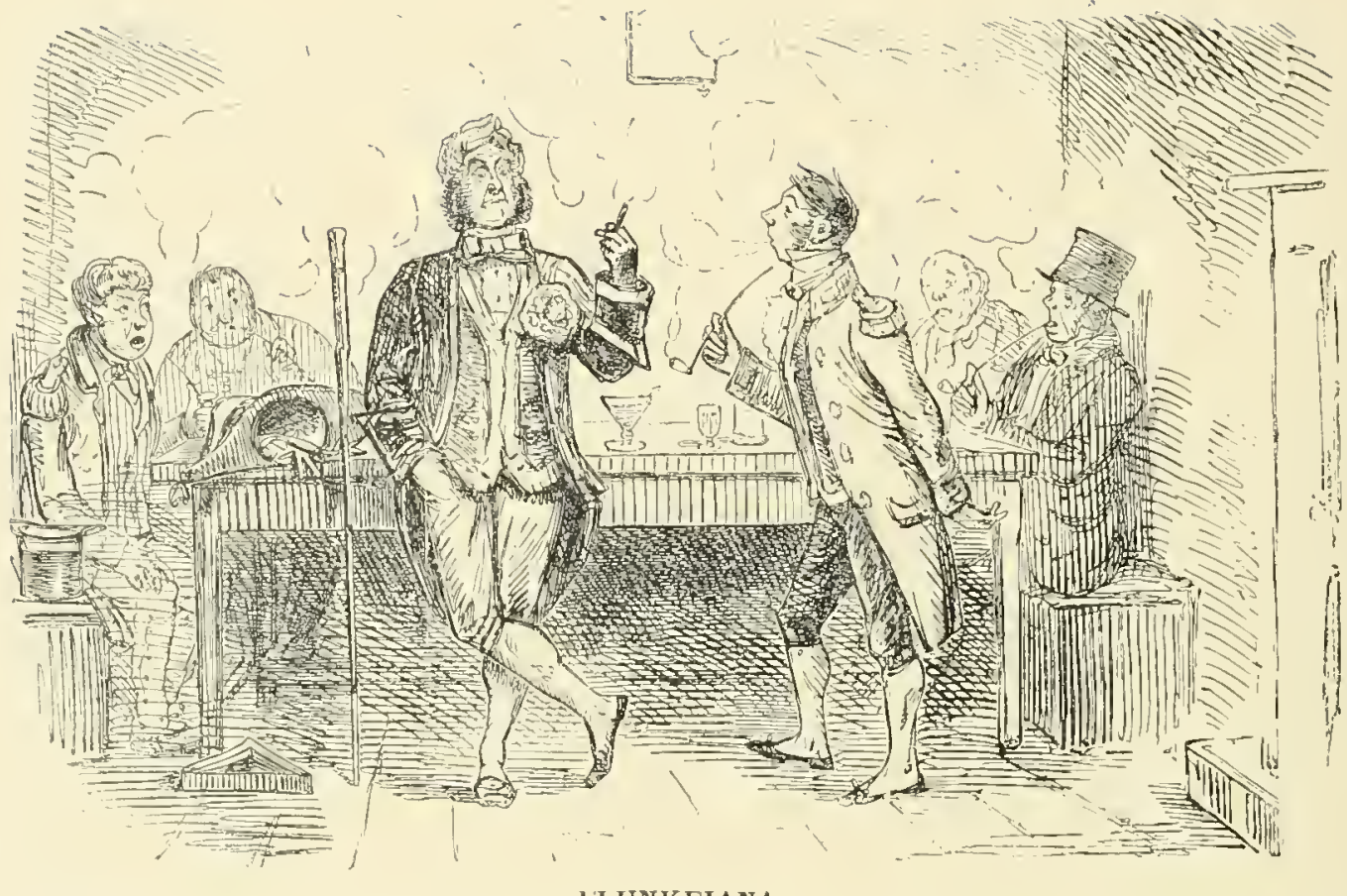

FLUNKEIANA.

SCENE-A PUBLIC-HOUSE BURY ST. EDMUND'S, AFTER THE DINNER GIVEN BY THE MAYOR OF BURY TO THE LORD MAYOR OF LONDON.

Conntry Footmun meckly inquires of London Footmun. "Pray, Sir, what do you think of our town? A nice place, ain't it?"

London Footman, condescendingly. "Vell, Joseph, I likes your town well enough. It's clean; your streets are hairy; and you've lots of rewins. But I don't like your champagne; it's all gewsberry." 


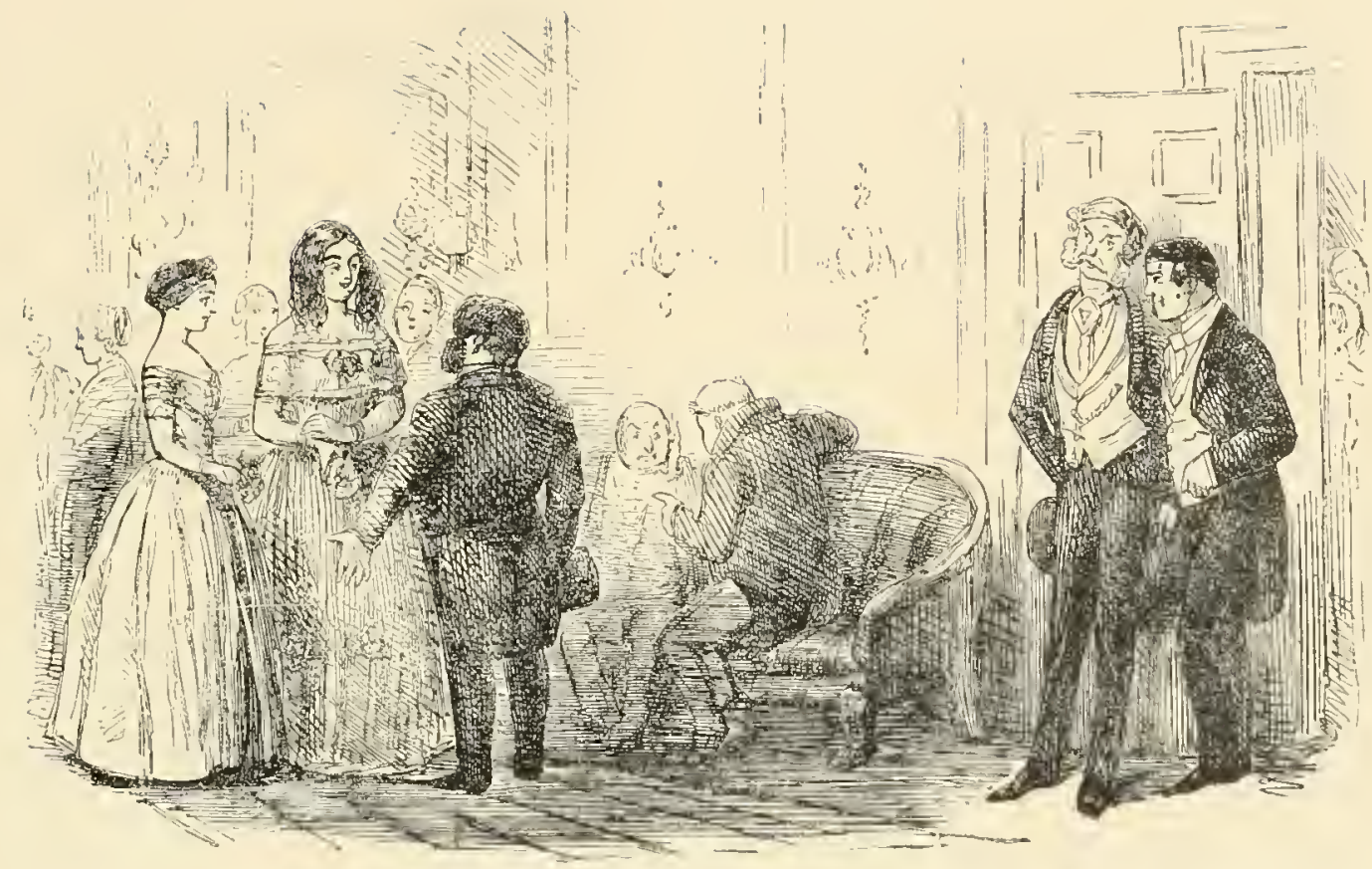

Sporting . Man (loquitur). "I say, Charles-that's a promising little filly along o' that bay-haired woman who's talking to the black-cob-looking man!" 


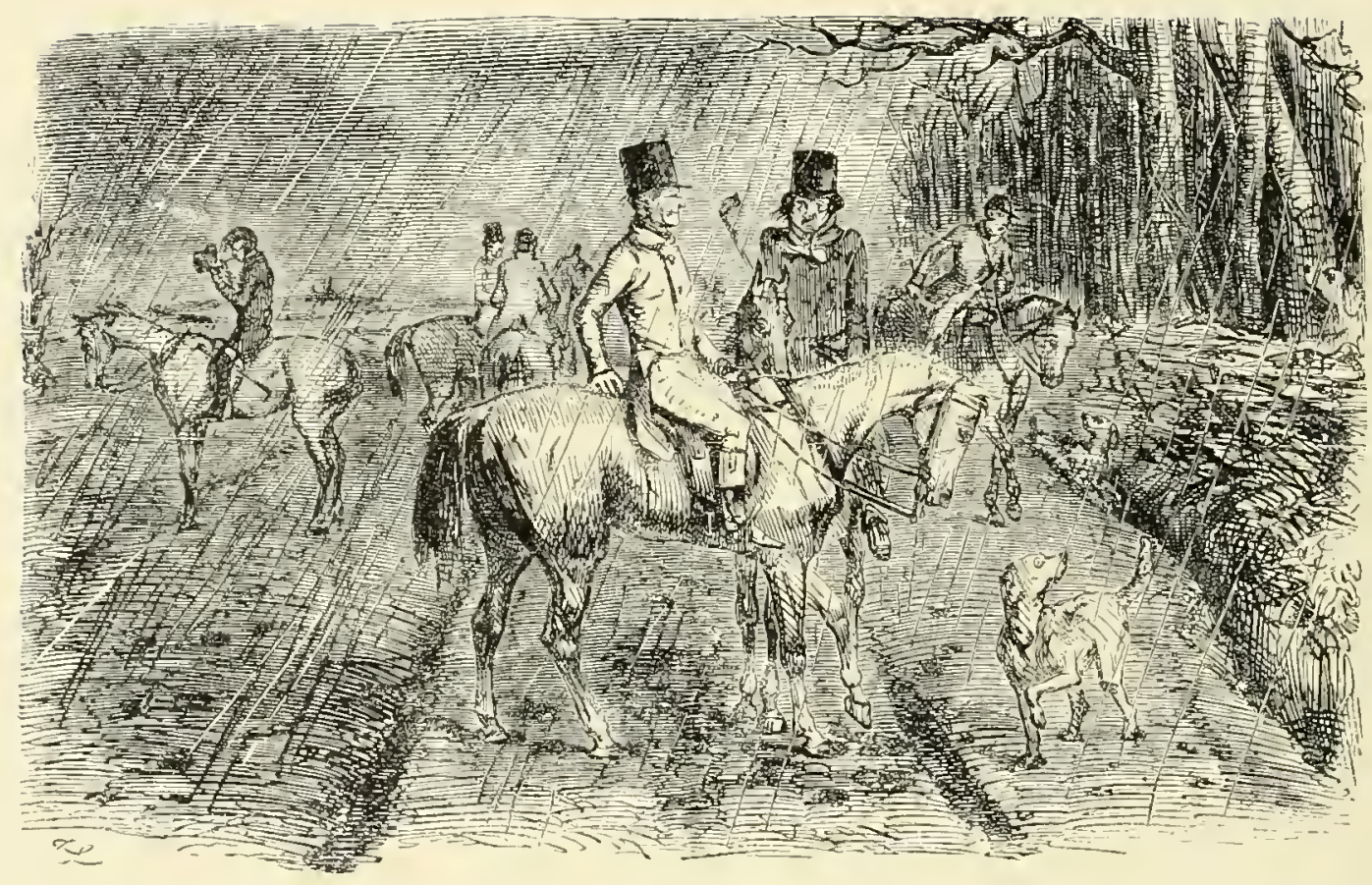

Country finend to Sporting Gent from Town. "Well, Jack, I told you we should have a capital day. You see the frost is quite gone." 


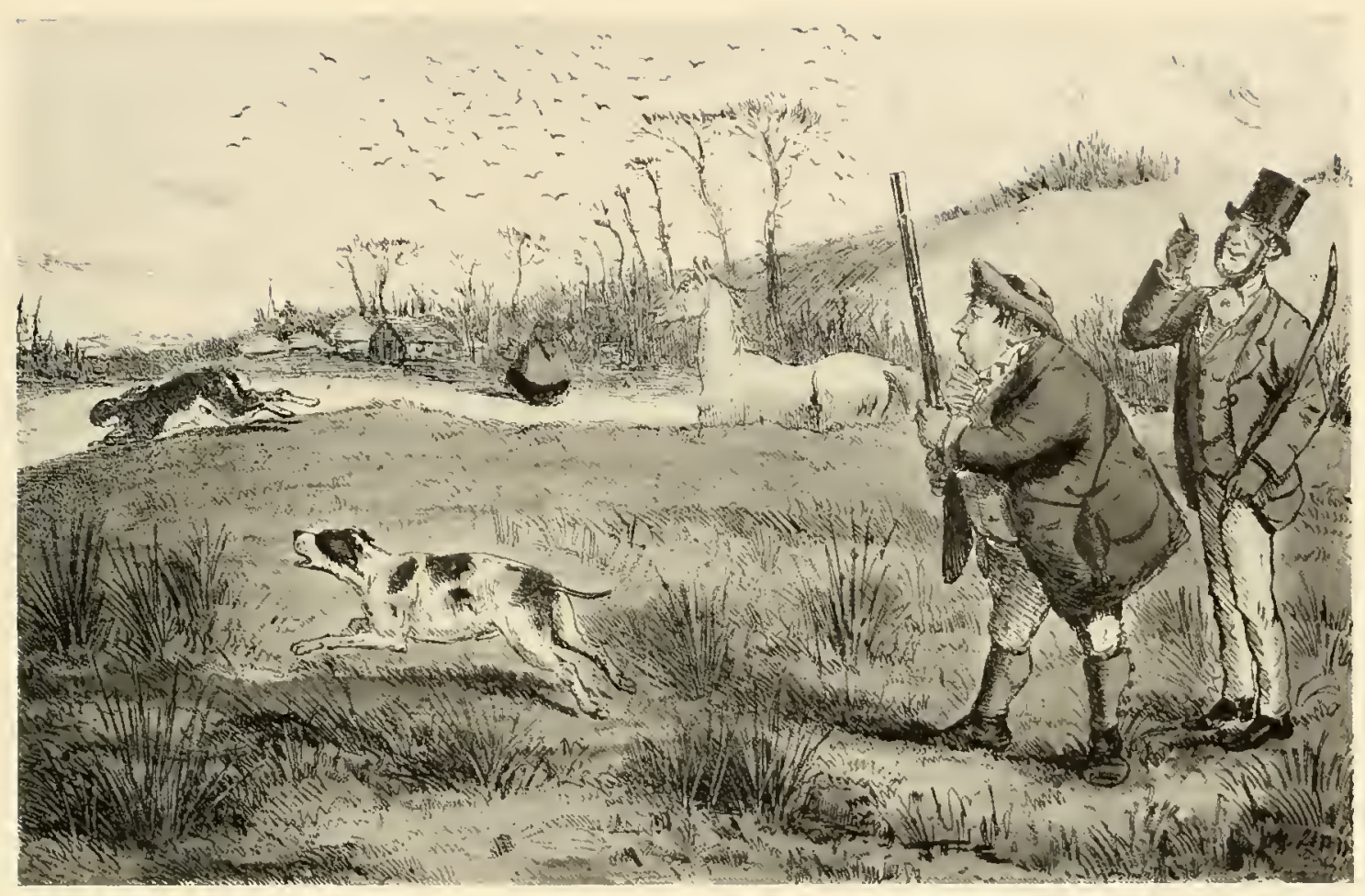

Mr. Jogglebury Crowdey with his dog and his gun.-From "Mr. Spongc's Sporting Tonr." 


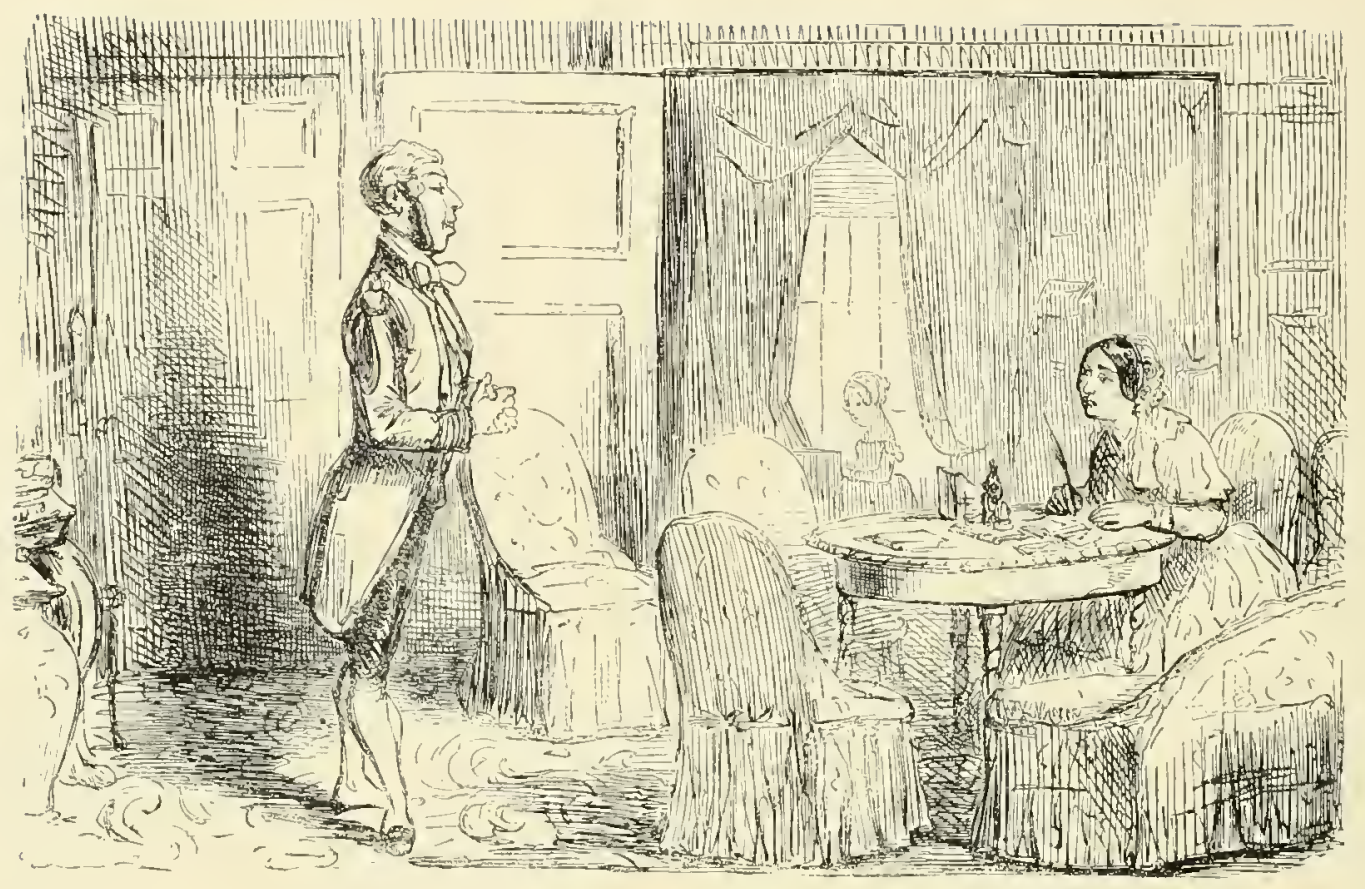

FLUNKEIANA.

Lady. "You wish to leave - really it's very inconvenient. Pray - have you any reason to be dissatisfied with your place?"

Flunkey. "Oh, dear no, Ma'am-not dissatisfied exactly; but-a-the fact is, Ma'am, you don't keep no wehicle, and I find I miss my carriage exercise." 


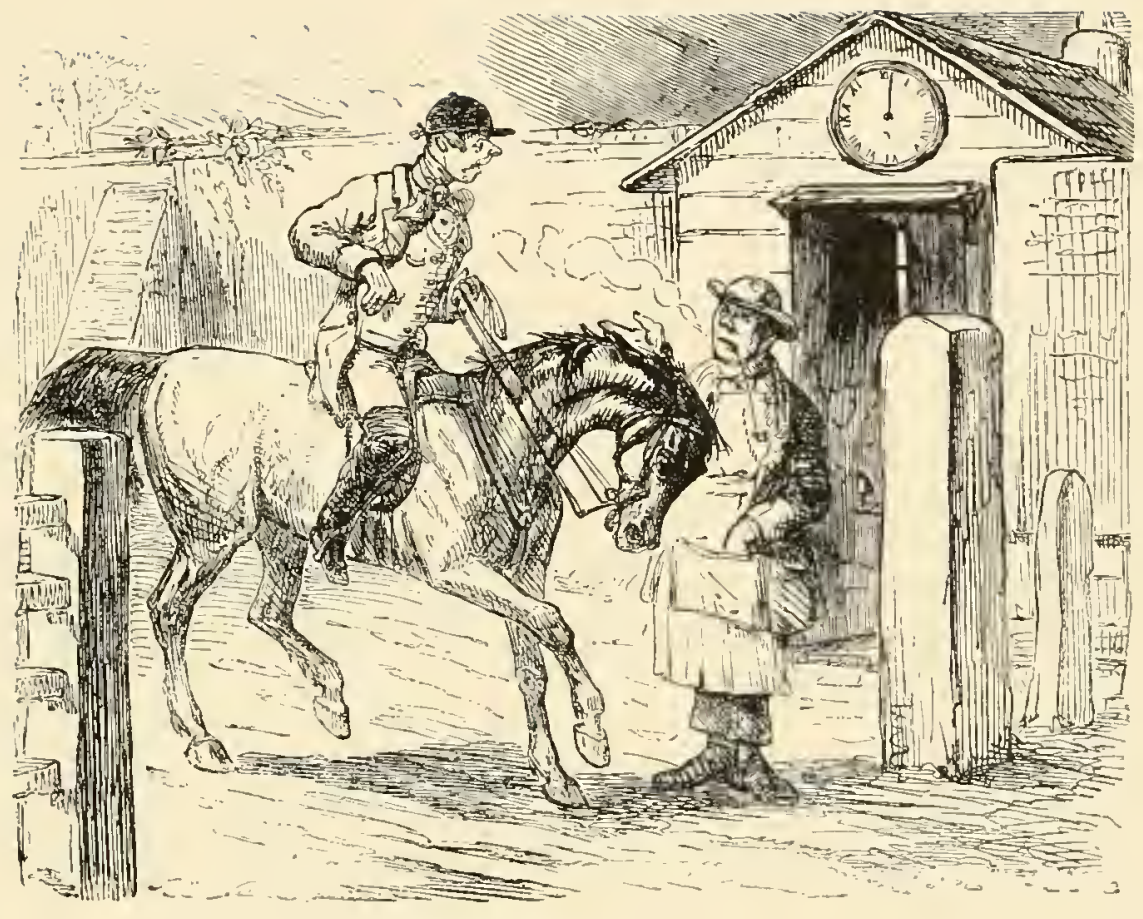

A SELL.

Enter SPORTING YOUTH who has lost the honnds.

Youth. "Seen the hounds go through here, Pikey?"

Pikey. "E-as, a have tuppense!" (Youth pay's the twopence and gallops ont)

A lapse of tarenty minutes is supposed to have tuken place, when 


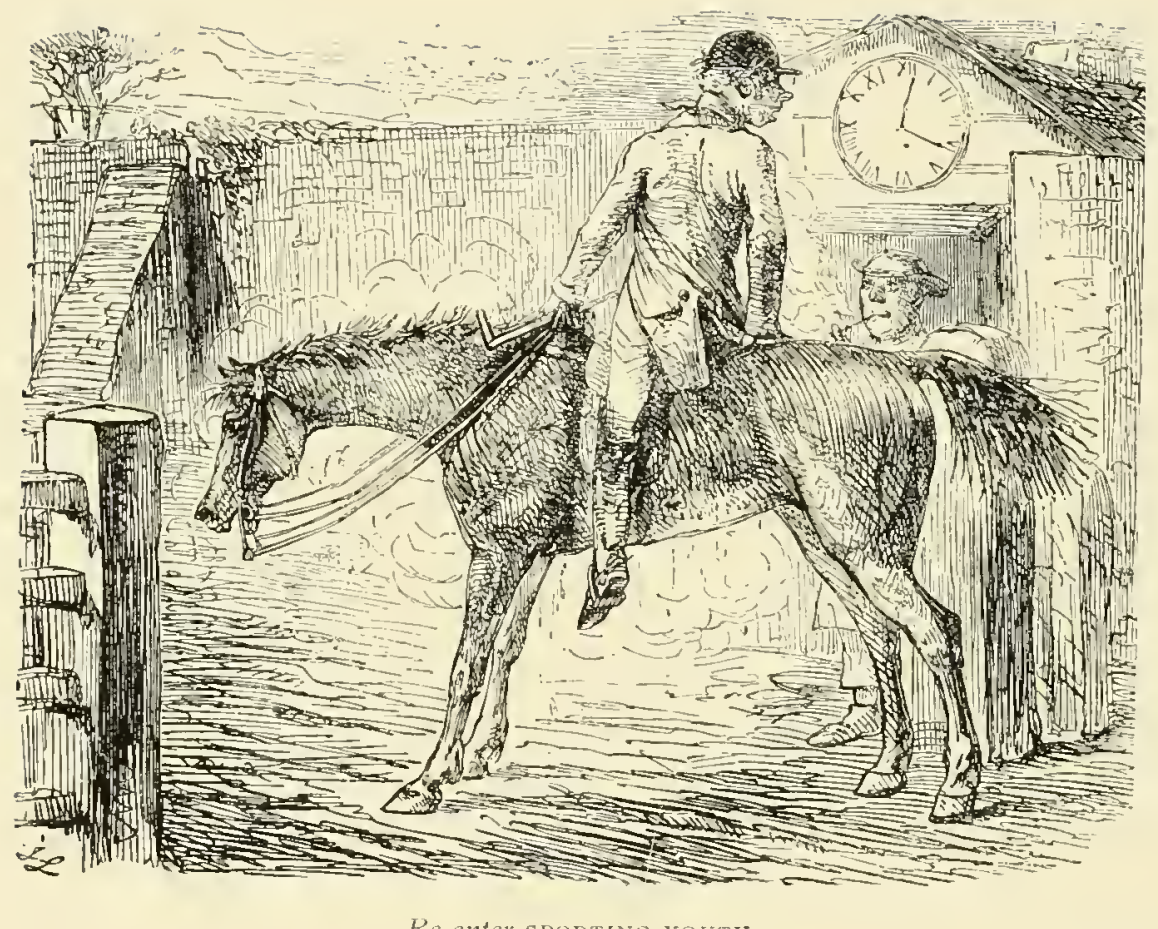

\section{Re-cnter SPORTING YOUTH.}

Youth (in a high state of excitcment). "Why, confound you! I thought you told me you had seen the hounds go through here?"

Pikcy. "E-as, so a did; seed 'em yesterday!" 


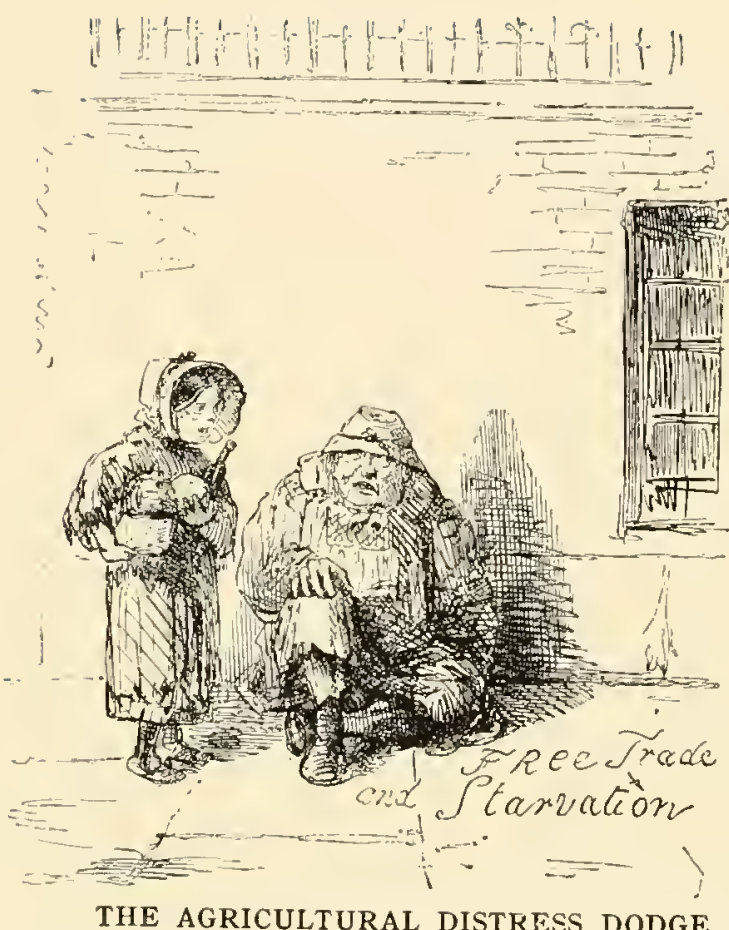

Beggar. "Did you get the lamb's fry?"

His Child. "All right."

Beggar. "Well, now, run home and tell yer mother not to boil the sparrergrass till I come." 


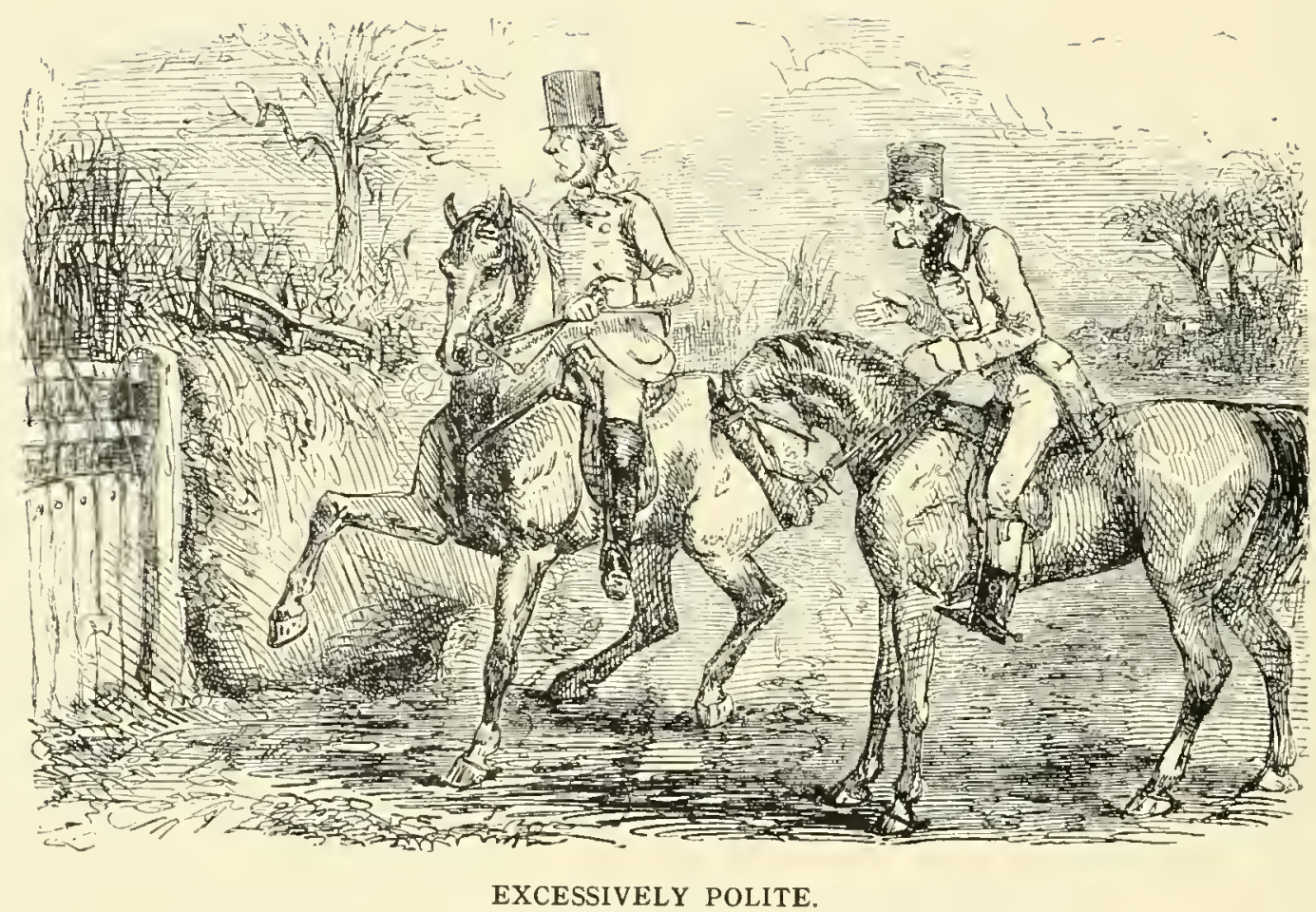

II'cll-bred Man. "Your horse seems a little impatient, Sir! Pray go first." 


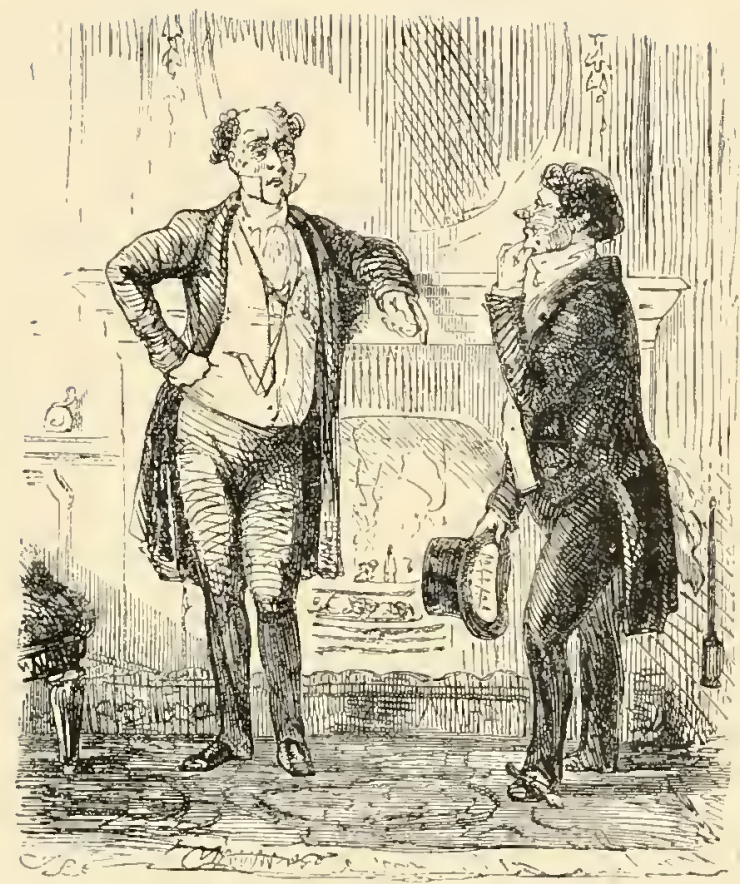

FLUNKEIANA.

Gcutlcman. "Sixty pounds a year!! Why, man, are you aware that such a sum is more than is frequently given to a curate?"

Flunkcy. "Oh, yes, Sir; but then you would hardly, I hope, go for to compare me with the hinferior order of clergy." 


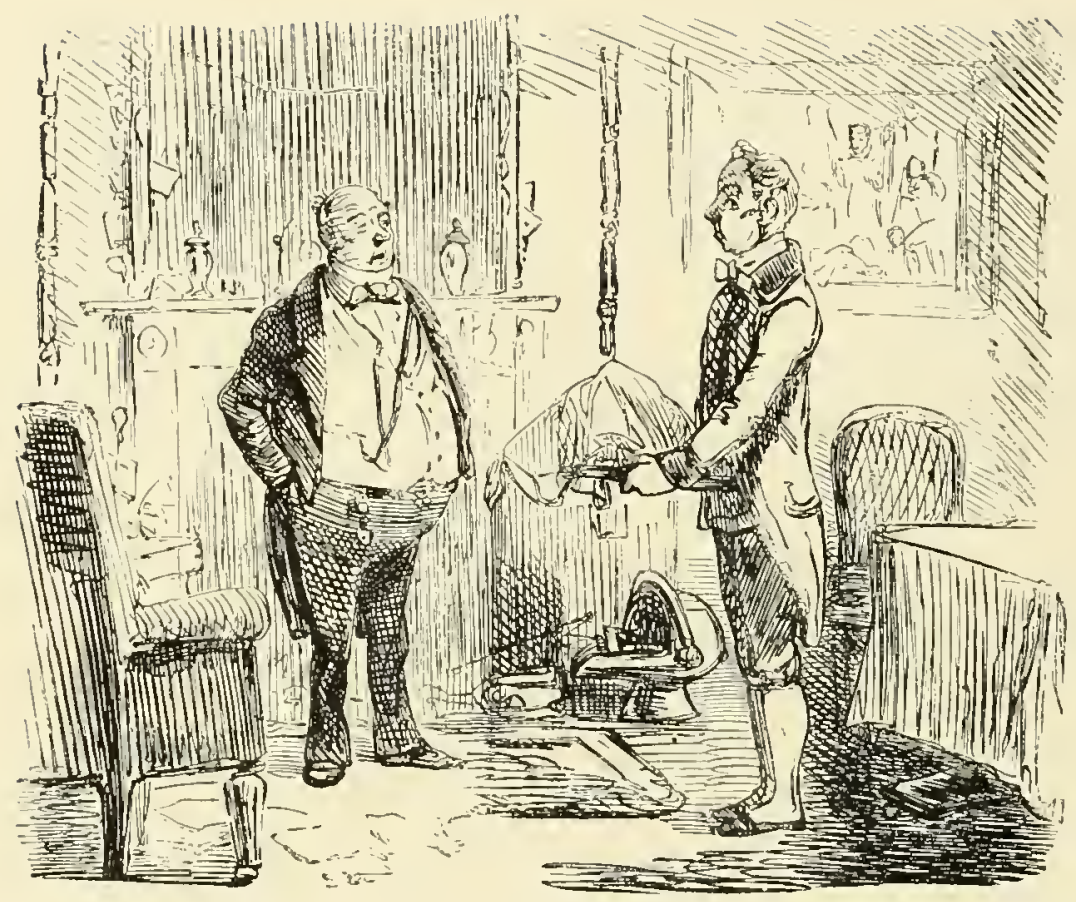

FLUNKEIANA.

Old Gont. "Thomas, I have always placed the greatest confidence in you. Now tell me, Thomas, how is it that my butcher's bills are so large, and that I always have such bad dinners?"

Thomas. "Really, Sir, I don't know, for I am sure we never have anything nice in the kitchen that we don't always send some of it $n p$ into the parlour!" 


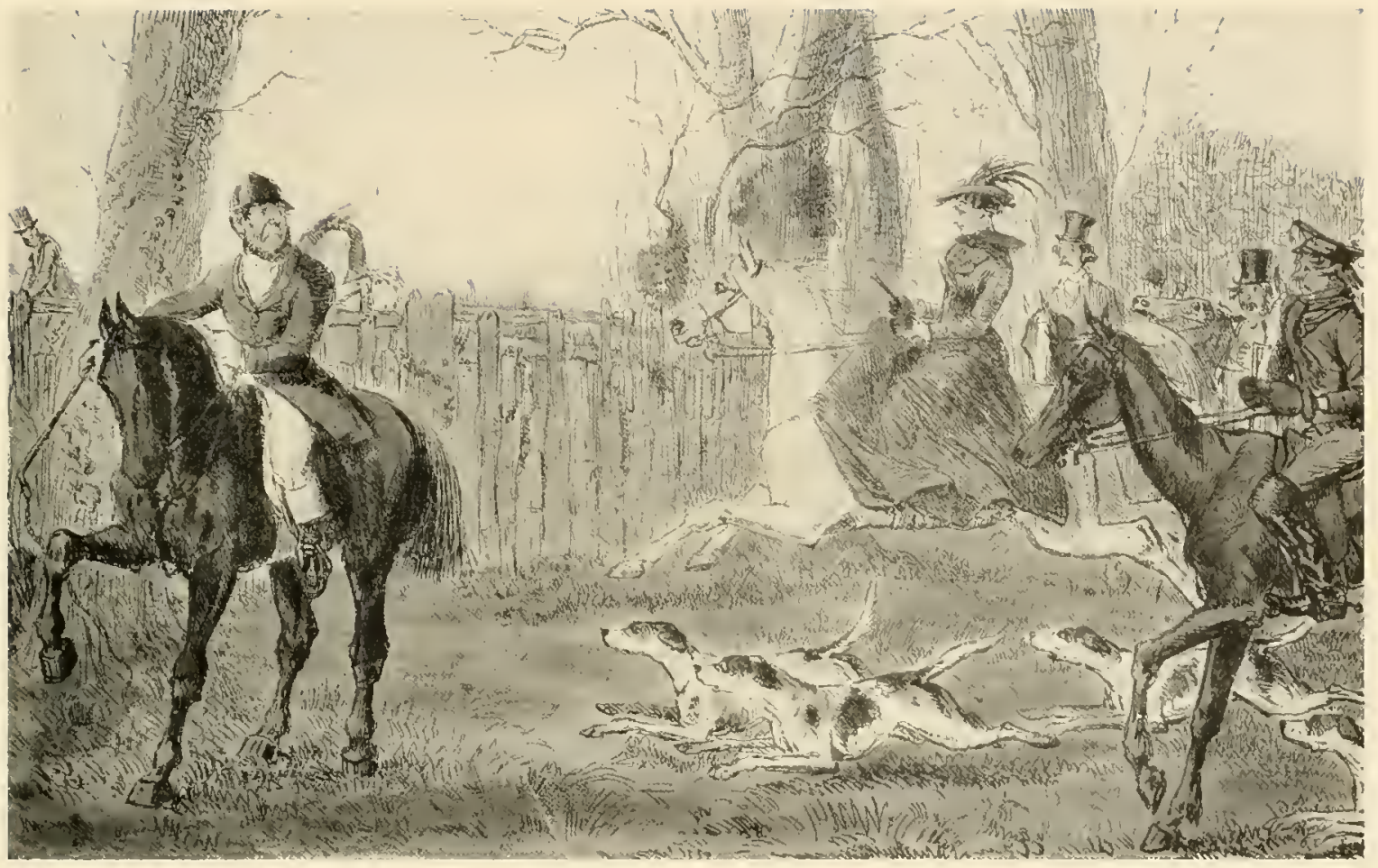

Lucy Glitters showing the way.-From "Mr. Sponge's Sporting Tour." 


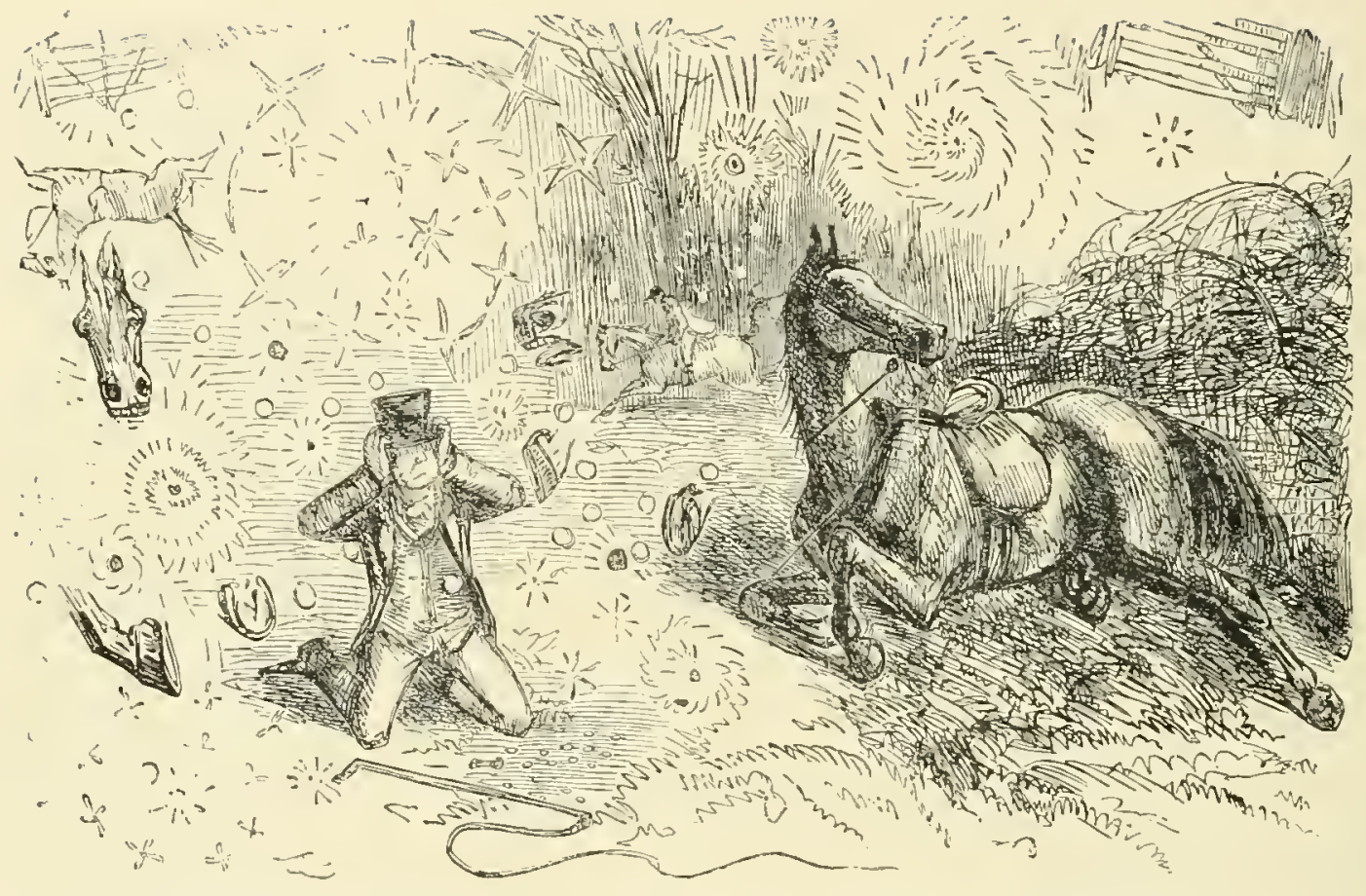

HUNTING MEMORANDUM.-APPEARANCE OF THINGS IN GENERAL TO A GENTLEMAN WHO HAS JUST TURNED A COMPLETE SOMERSAULT!!

* \&c. \&c. represent sparks of divers beautiful colours. 


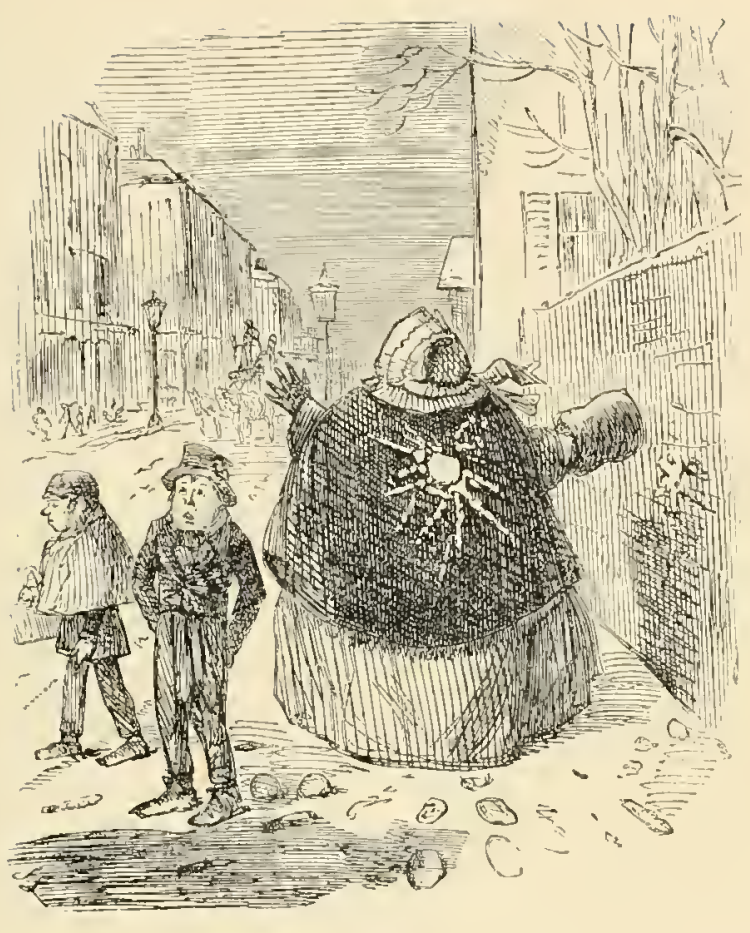

SNOW-FLAKES.-No. I.

Strcet Boy (to his natural cncmy, the Policeman). "Snowballs, Sir! No, Sir, I haven't seen no one throw no snowballs, Sir!"

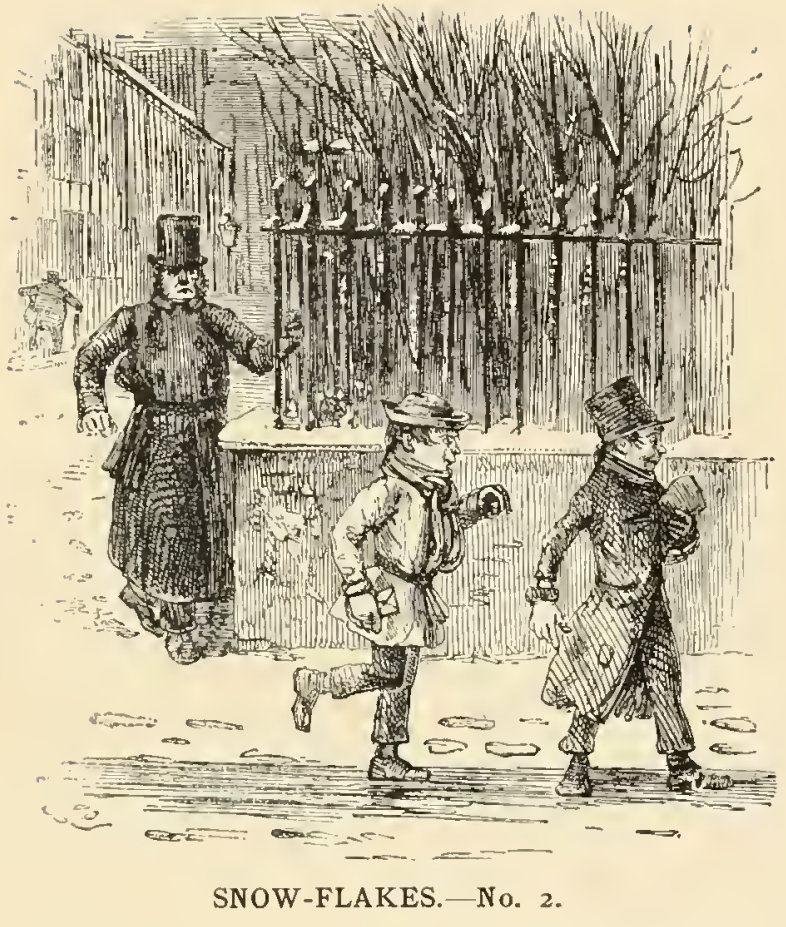

Strcet Boy. "Hoh! soosanner! don't yer cry for me! fol de rol de riddle lol. Here's a jolly slide. Cut away young 'un. It's all serene!" 


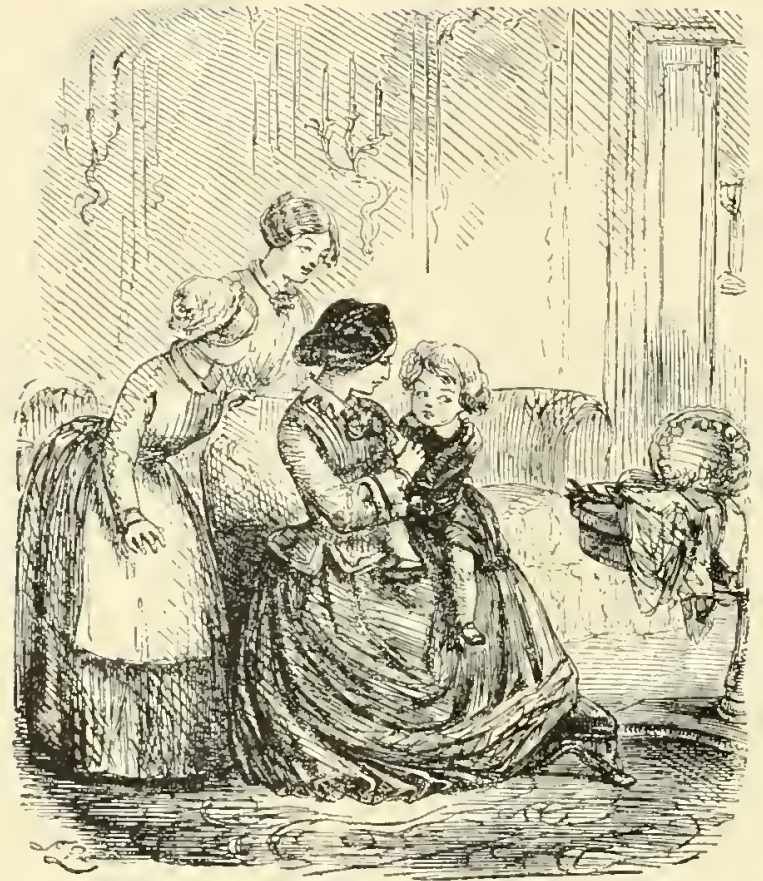

THE BIRTHDAY.

Consin Emily. "And so it's little Alfred's birthday to-morrow. Now, what would he like best for a present?" Alfred (after much reflection). "Why, I think I should like a-I should like a Testament-and-a-a-and-oh, I know! I should like a squirt!!" 


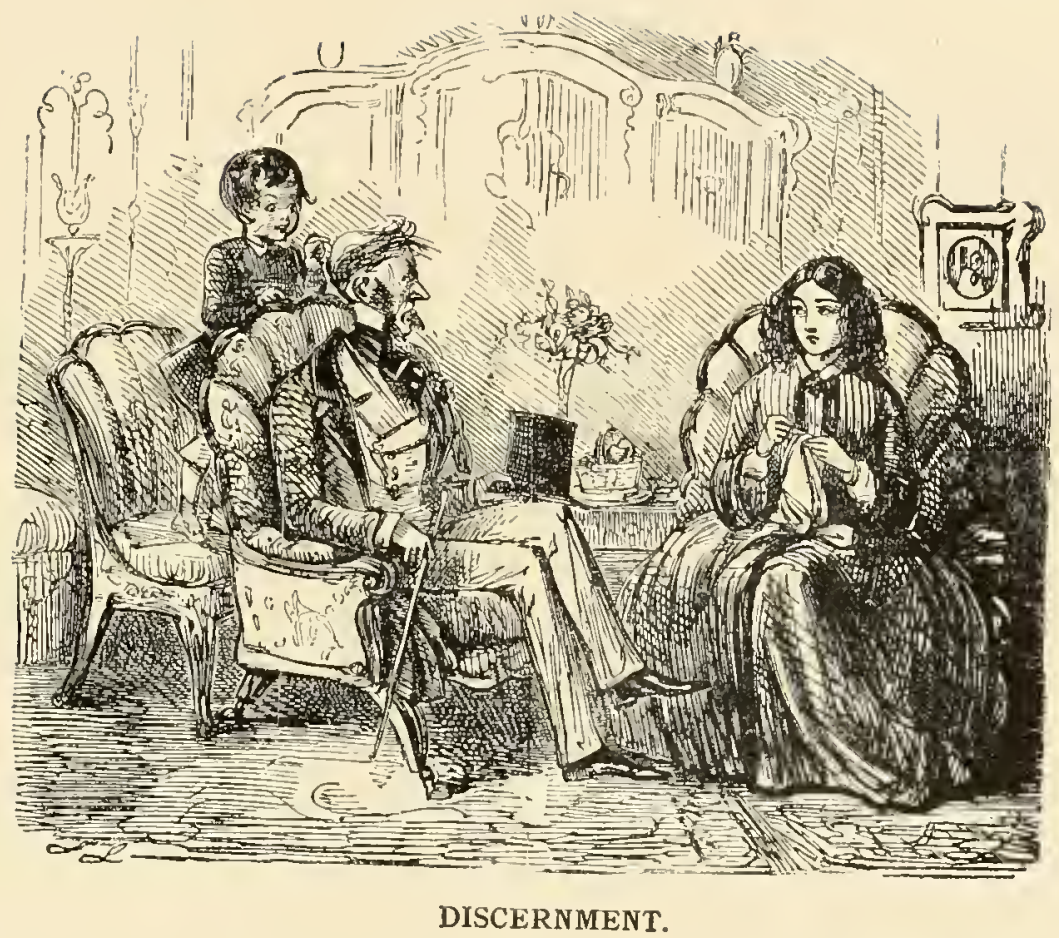

Clcver Clitd. "Oh! do look here, Mamma dear, such a funny thing! Mr. Boker's got another forehead at the back of his head." (BOKIR is delighted.) 


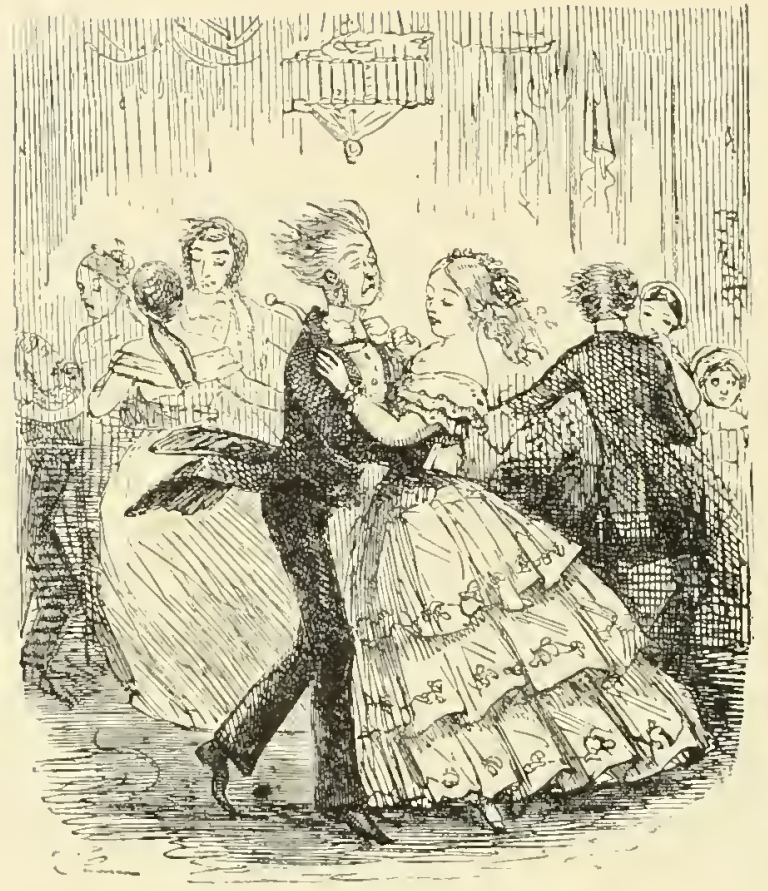

A FALSE POSITION.

Individual (who is not over strong $2 n$ his head, or firm on his lcgs). " D-d-d-d-id waltzing - ever-make-yougiddy? Because, I-shall--be-happy-to-sit-downwhenever-you're-tired!"

Girl (who is in high dancing condition). "Oh, dear, no -I could waltz all night!" 


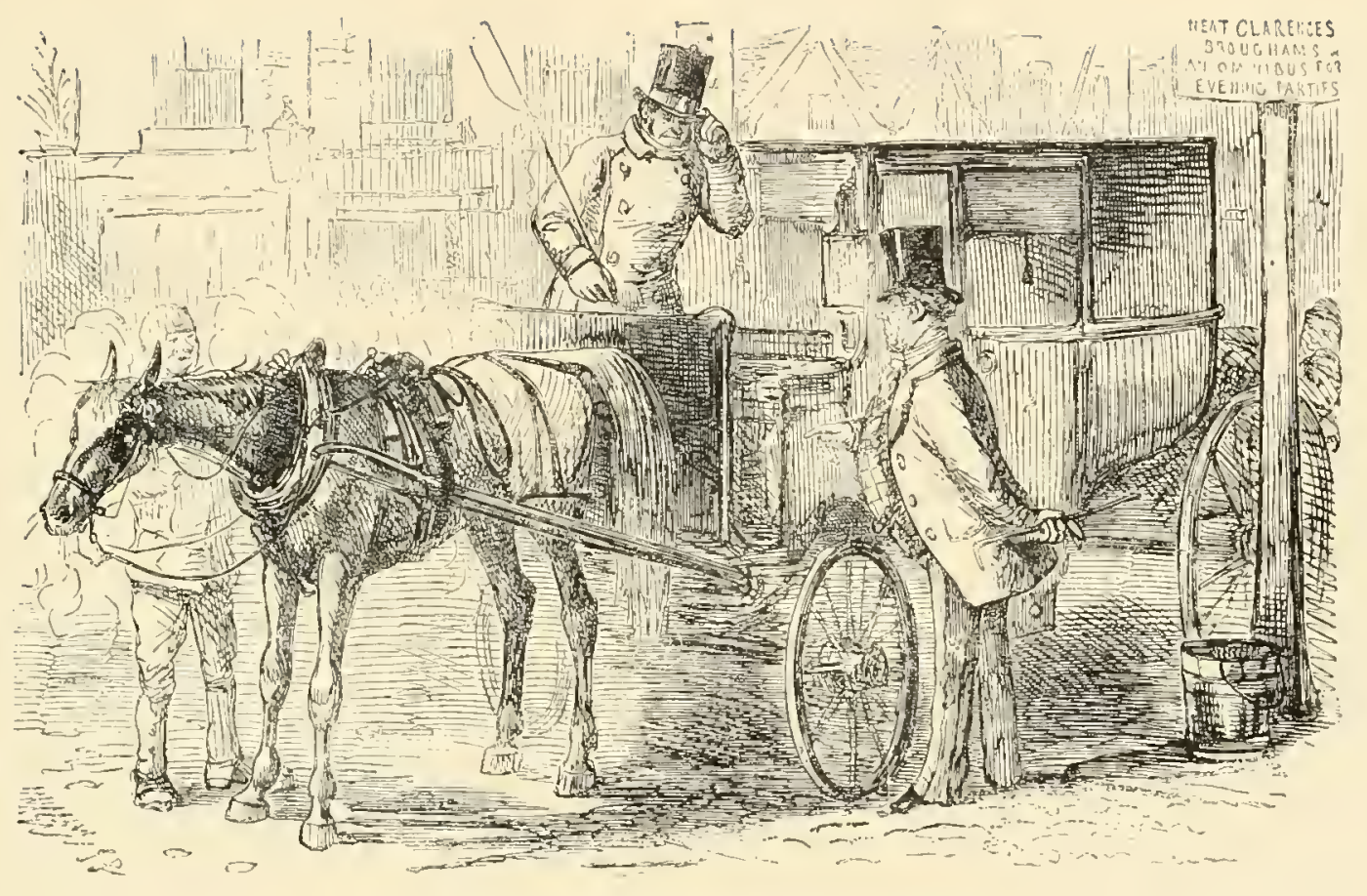

THE CONSCIENTIOUS STABLE-KEEPER.

Gent (who meditates a ride). "Hallo! why, confound it. That's my saddle horse, isn't it?"

Fly-Mun. "Yes, Sir! it's all right; Master says you're werry particular about 'avin of 'im exercised regular - so we puts 'im into the broom when you ain't out a ridin'!" 


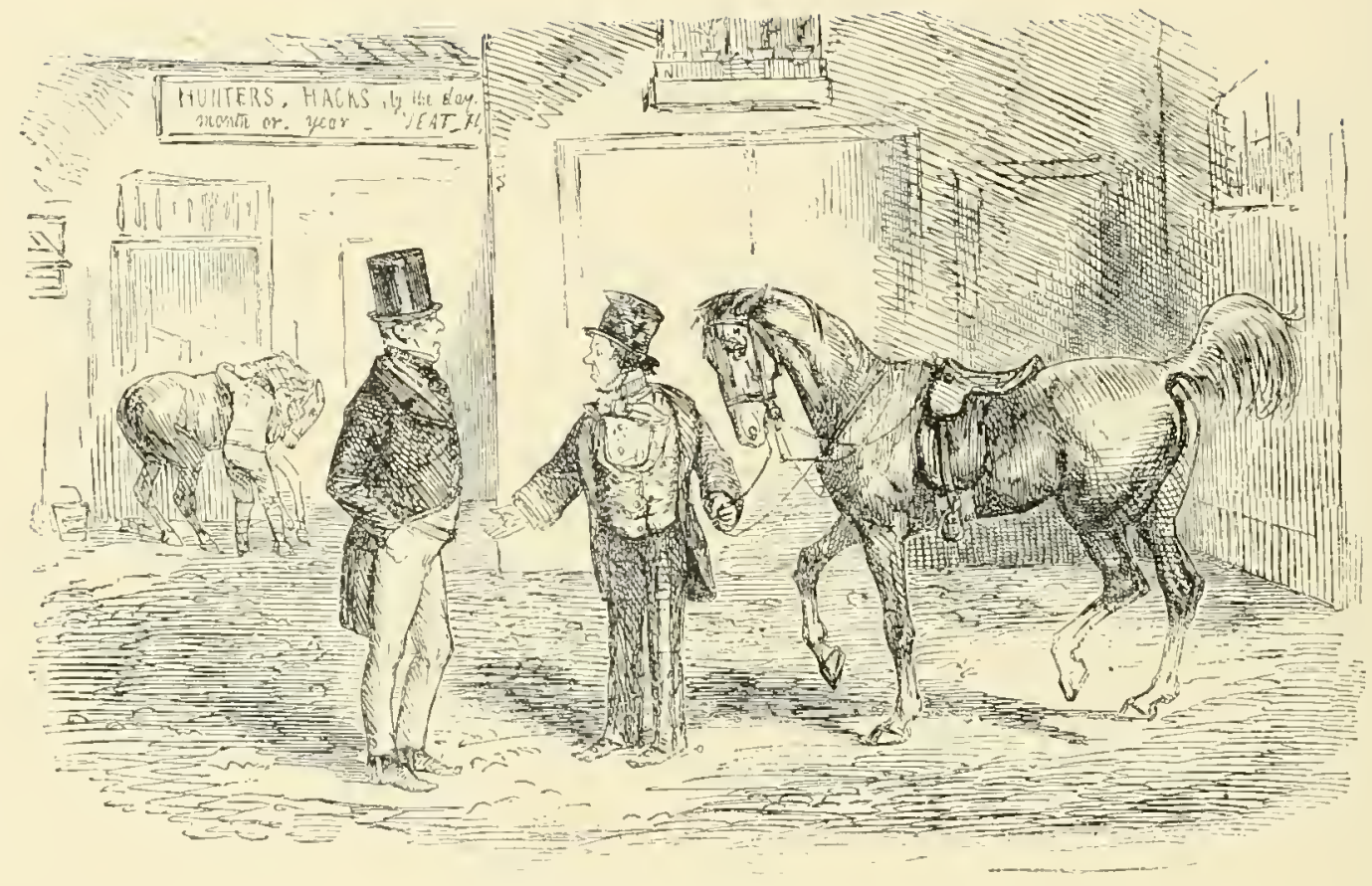

A HACK FOR THE DAY.

Stable-Kecper (to little Gent)

he always was a light-'arted 'oss." 


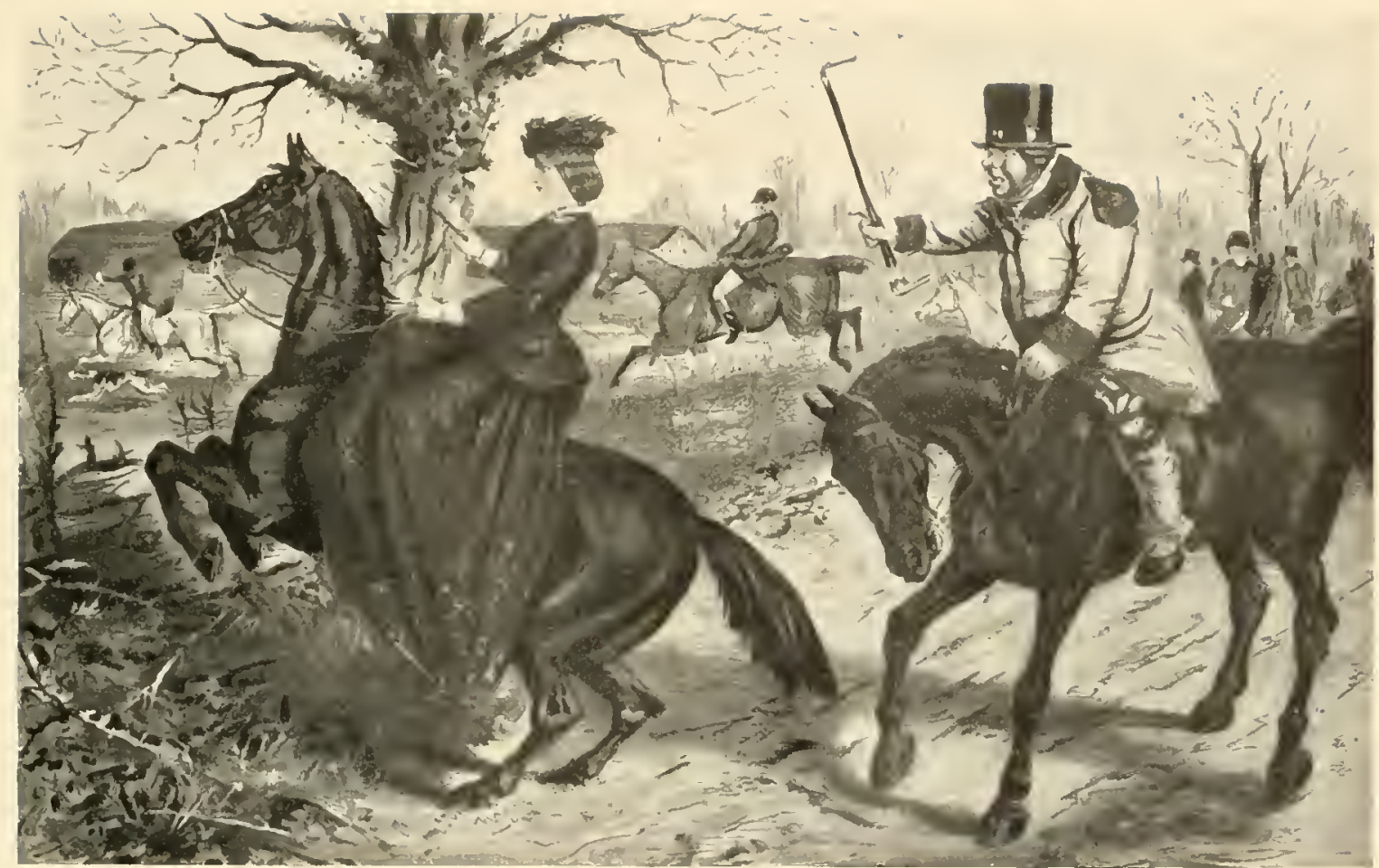

GONE AWAY :

Old Coachntan. "Now Miss Ellen! Miss Ellen! You know what your Pa said! You was to take the greatest care of Jerry."

Miss Ellcn. "So I will Robert! and that's why I'm taking him off the nasty hard road, poor thing!" 


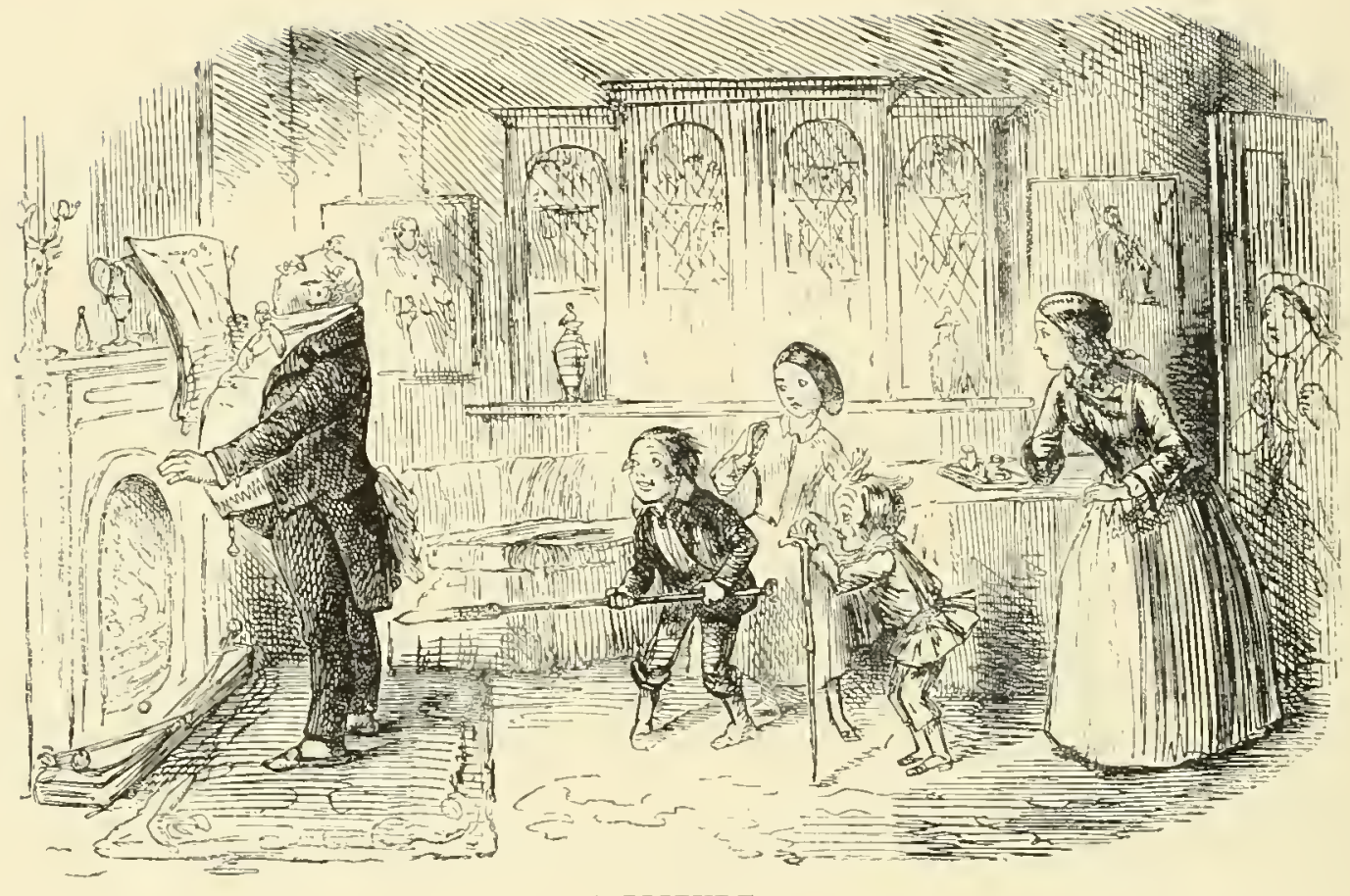

A PICTURE.

Showing what Master Tom did af-ter see-ing a pan-to-mime-but you would not do so-oh dear no!because you are a good boy. 


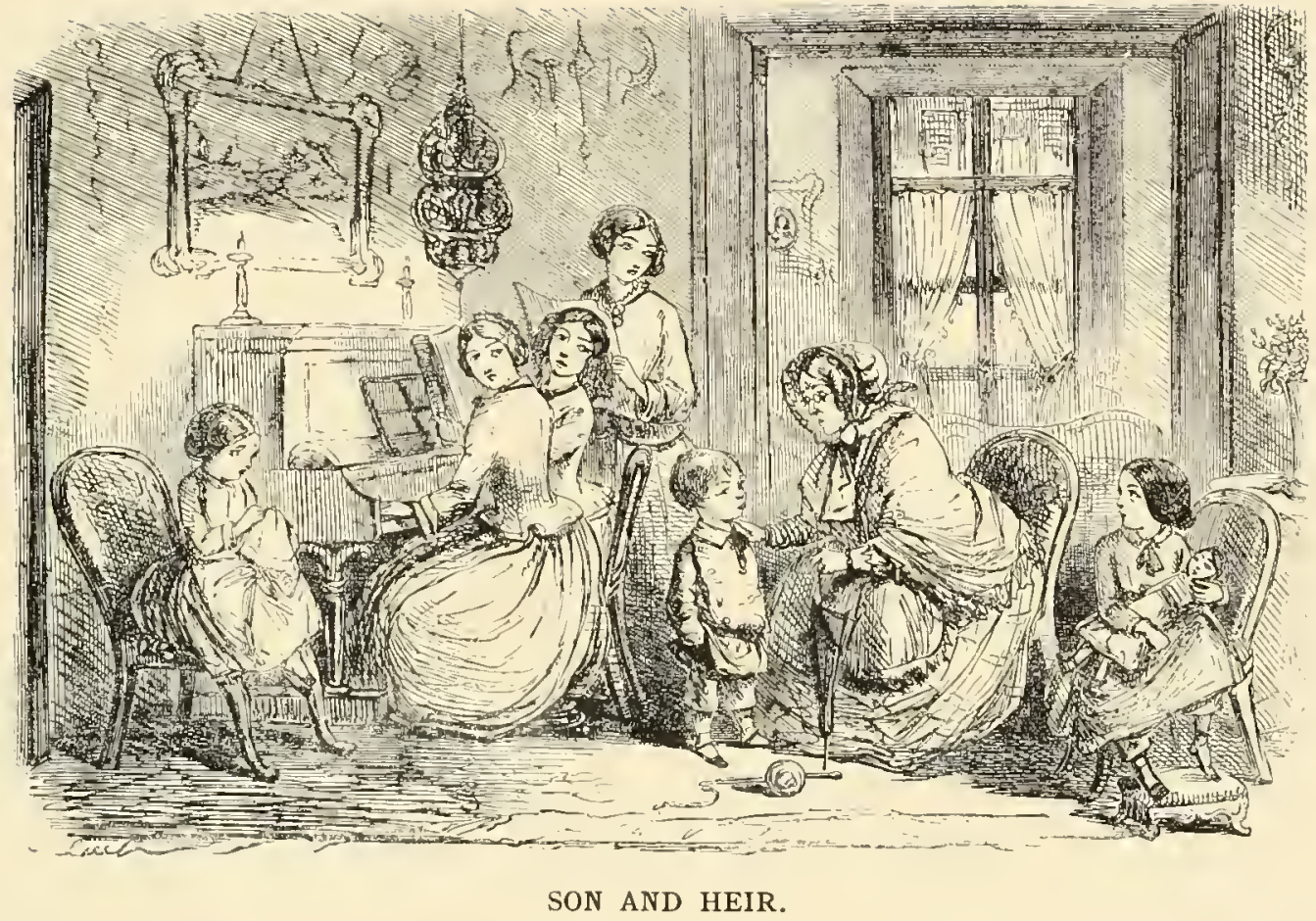

Son and Hcir. "How many of us are there? Why, if you count the girls, there are six-but some people don't count the girls.- I'm one." 


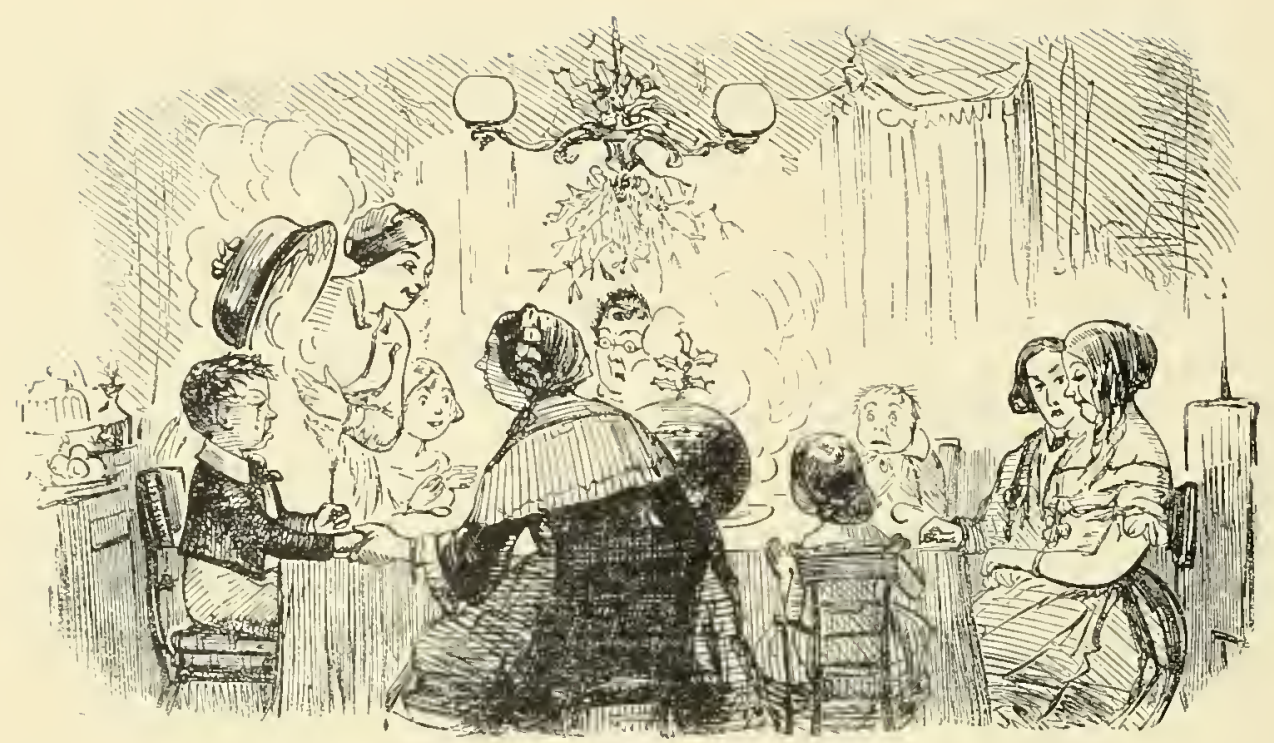

A CAUTION TO LITTLE BOYS AT A FESTIVE SEASON.

Mamma. "Why, my dearest Albert, what are you crying for? - so good, too, as you have been all day!"

Spoiled Little Boy. "Boo-hoo! I've eaten so-much be-ef and t-turkey, that I can't eat any p-plum p-p-pudding!"

[Oh, what a wery greedy little fellow. 


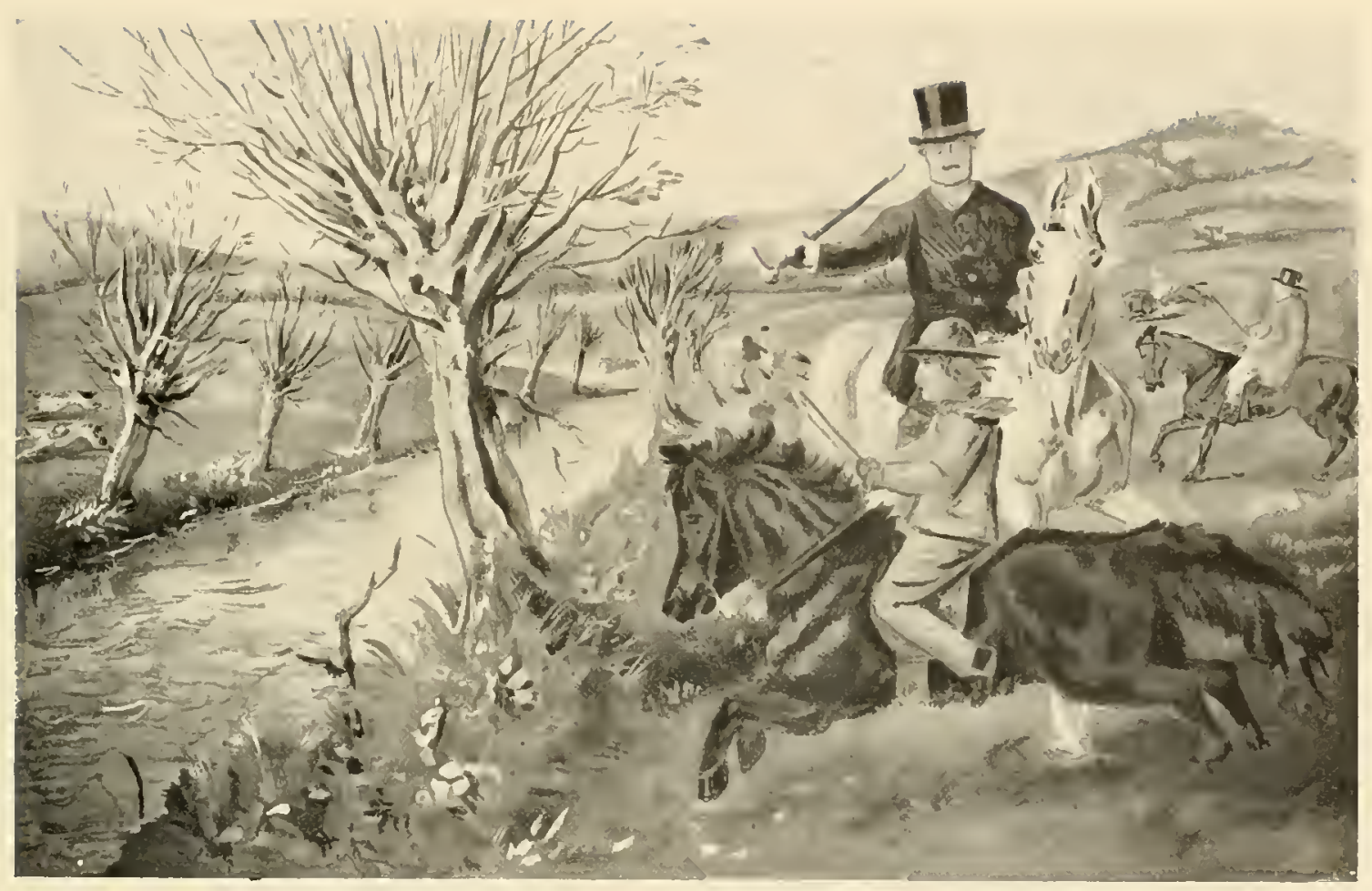

Ruggles. "Hold hard, Master George - it's too wide, and uncommon deep!" Master Gcorge. "All right, Ruggles! We can both swim!" 


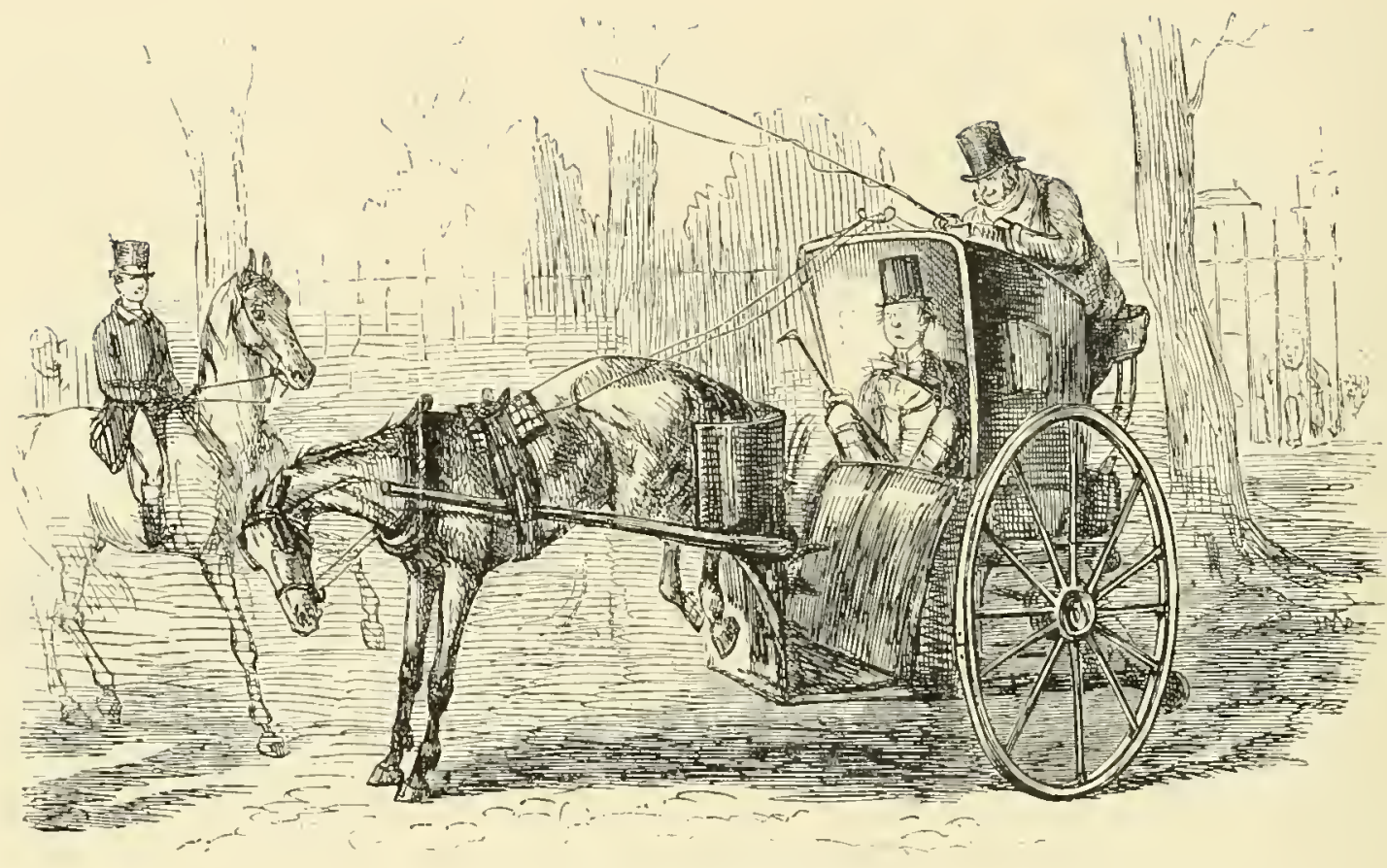

A PLAYFUL CREATURE.

Cabby, "Don't be alarmed, Sir, it's only his play." 


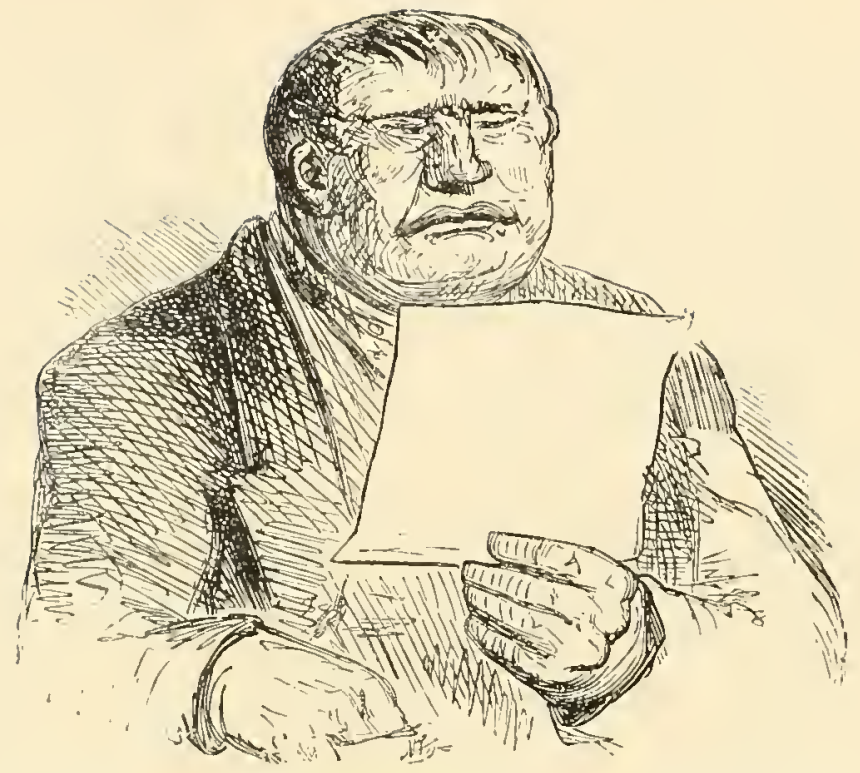

A SKETCH OF CHARACTER BY PROFESSOR MILKANSOP, THE CELEBRATED GRAPHIOLOGIST.

Gentliman (reads). "Intelligent; strong religious feelings! fond of little children; loves music, poetry, and the fine arts; is reluctant to take offence, generous, and forgiving.'Well, I'm blowed, if that ain't wonderful; why, it's my karactur to a T!" 


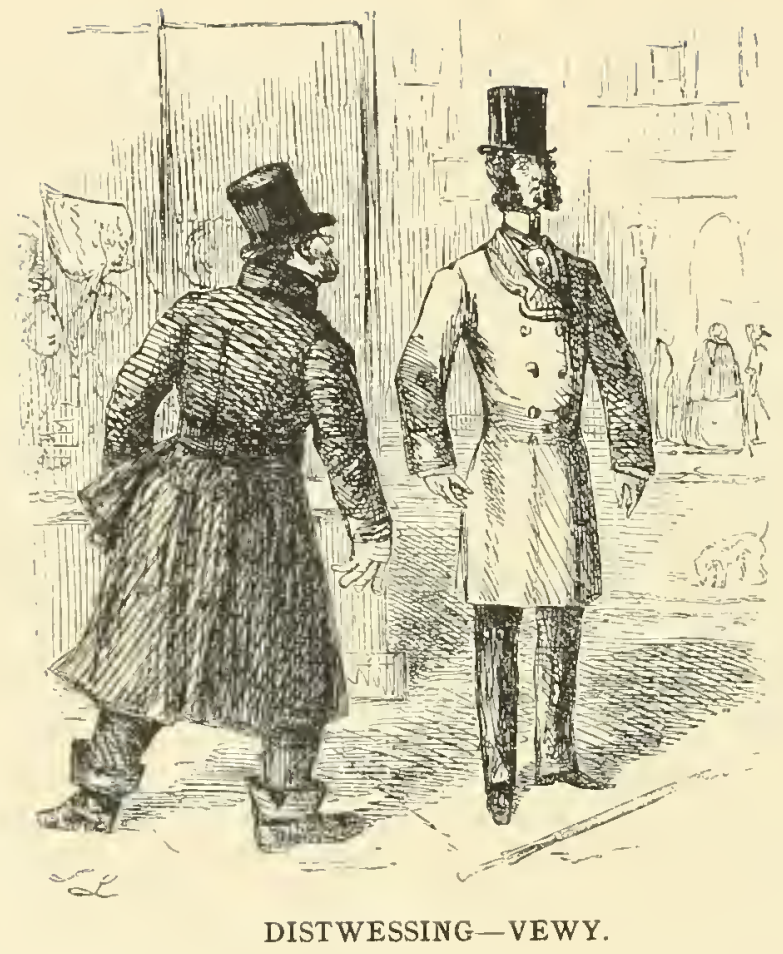

1. f2. "Did you call the police, Sir?"

Swcll (who would perish rather than disturb his shirt collar) "Ya-as, a-I've had the misfortune to dwop my umbrellaw, and there isn't a boy within a mile to pick it up a-will you have the goodness?" 


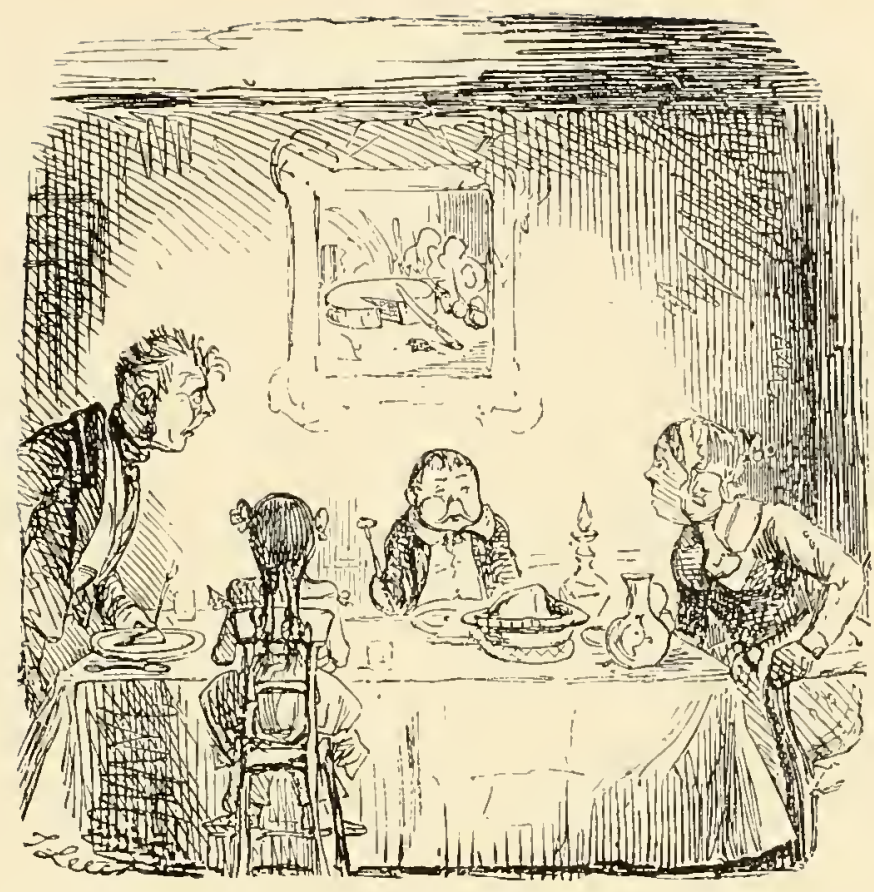

ALARMING SYMPTOMS AFTER EATING BOILED BEEF AND GOOSEBERRY PIE.

Little Boy. " Oh, lor, mar, I feel just exactly as if my jacket was buttoned." 


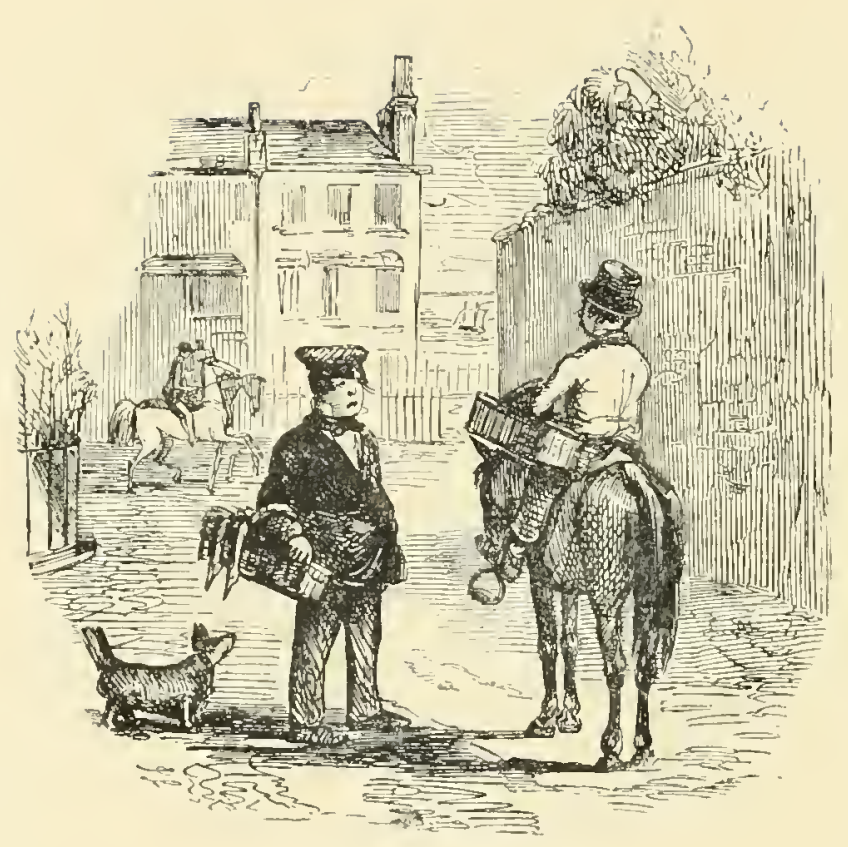

VERY LOW PEOPLE.

Purveyor of Poultry. "What sort o' people are they at number twelve, Jack?"

Purveyor of Mcat. "Oh! a rubbishin' lot. Leg o' mutton a' Mondays, and 'ash an' cold meat the rest o' the week." 


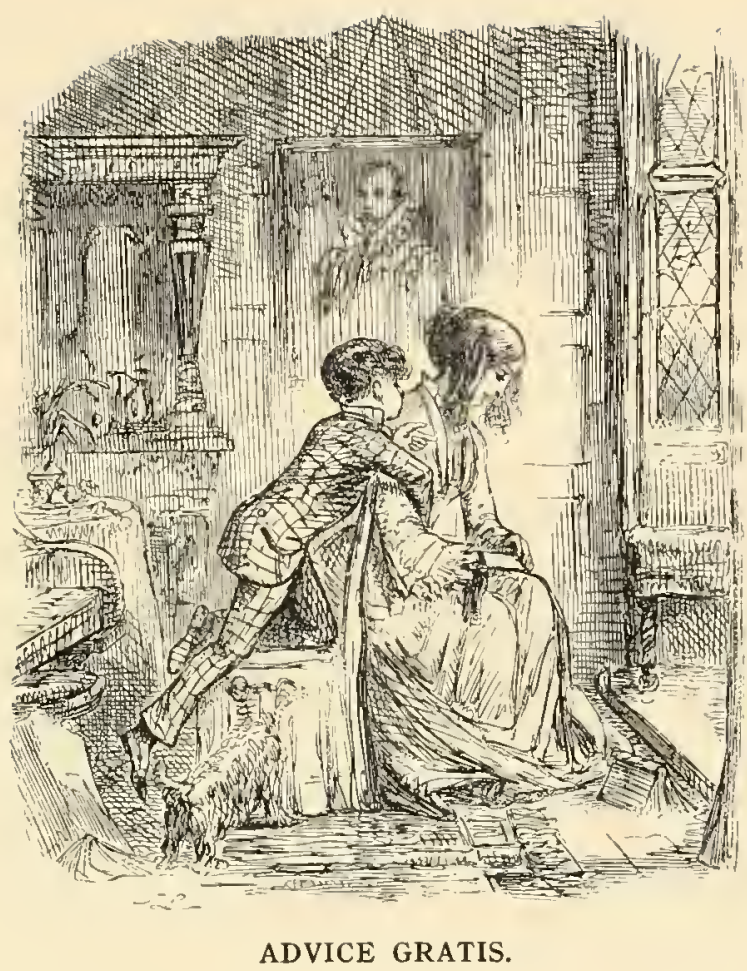

Ellen. "Oh, don't tease me to-day, Charley; I'm not at all well!"

Charley (a Man of the IV'orld). "I tell you what it is, cousin-the fact is, you are in love! Now, you take the advice of a fellow who has seen a good deal of that sort of thing, and don't give way to it!" 




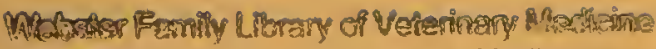

Qumbung Schno! of Veterinary Matiane al

Turs Lvivireity

200 Westiono fis 390

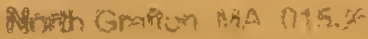




\section{•}

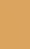


